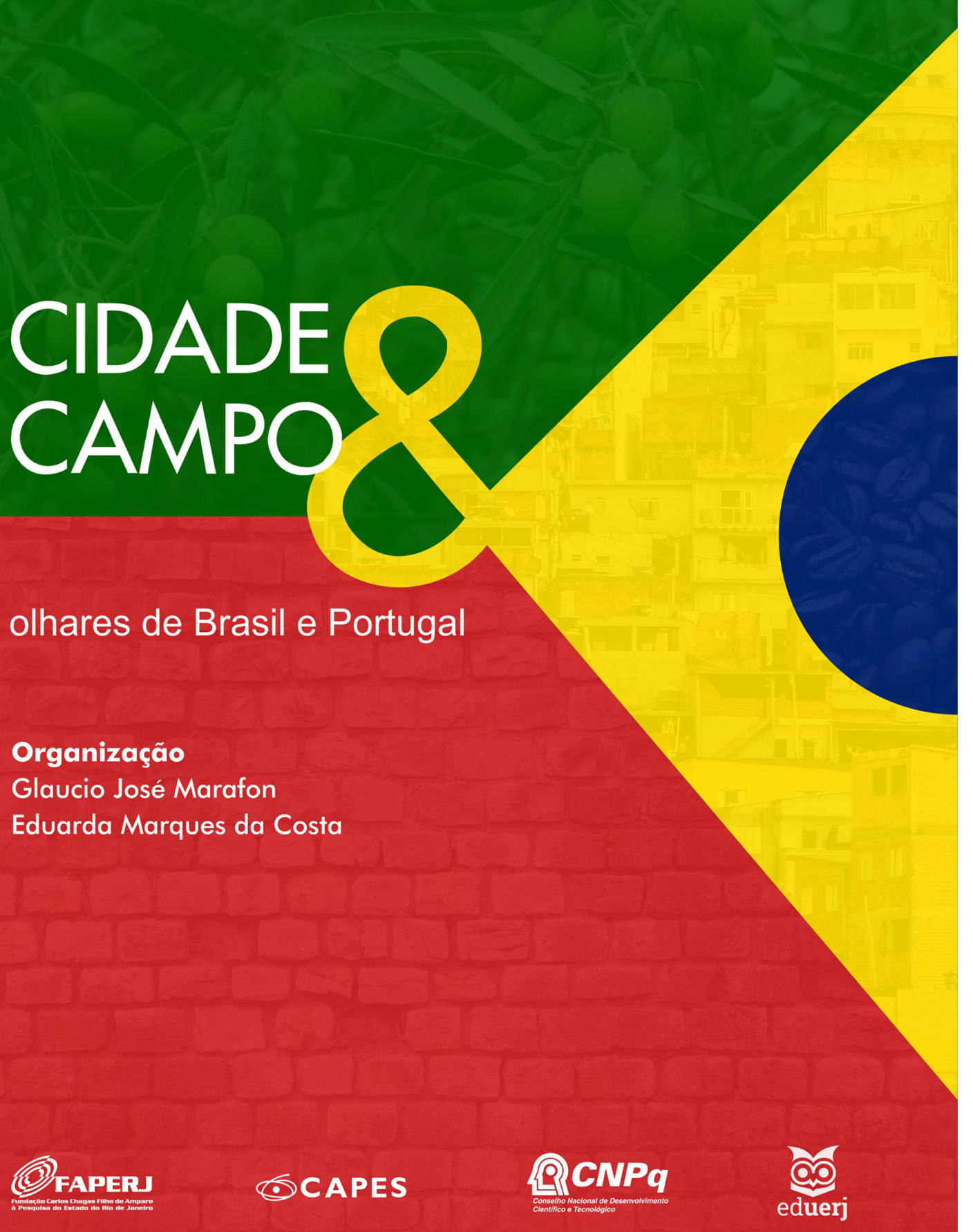




\title{
Cidade e campo olhares de Brasil e Portugal
}

\author{
Glaucio José Marafon \\ Eduarda Marques da Costa \\ (orgs.)
}

MARAFON, G. J., and COSTA, E. M., eds. Cidade e campo: olhares de Brasil e Portugal [online]. Rio de Janeiro: EDUERJ, 2020, 305 p. ISBN: 978-65-87949-05-5. https://doi.org/10.7476/9786587949055.

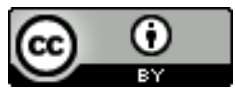

All the contents of this work, except where otherwise noted, is licensed under a Creative Commons Attribution 4.0 International license.

Todo o conteúdo deste trabalho, exceto quando houver ressalva, é publicado sob a licença Creative Commons Atribição 4.0.

Todo el contenido de esta obra, excepto donde se indique lo contrario, está bajo licencia de la licencia Creative Commons Reconocimento 4.0. 
Cidade e Campo:

Olhares de Brasil e Portugal 


\section{UNIVERSIDADE DO ESTADO DO RIO DE JANEIRO}

Reitor

Ricardo Lodi Ribeiro

Vice-reitor

Mario Sergio Alves Carneiro

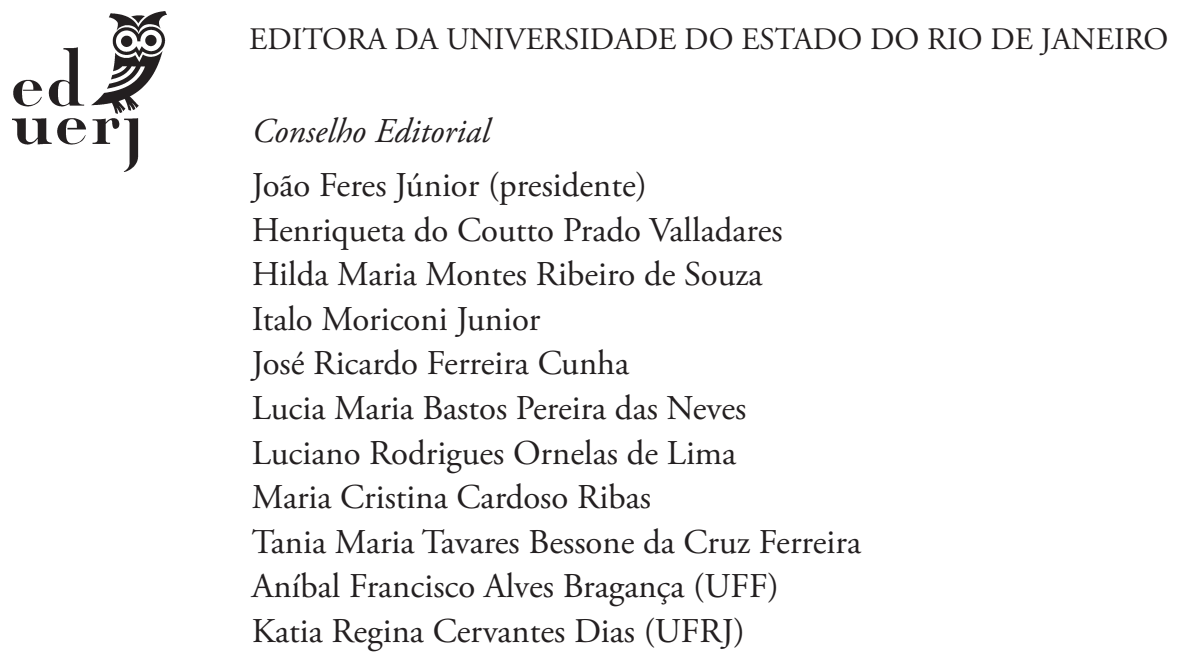




\author{
Organização \\ Glaucio José Marafon \\ Eduarda Marques da Costa
}

\title{
Cidade e Campo:
}

\section{Olhares de Brasil e Portugal}

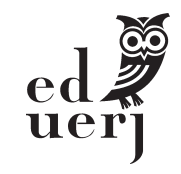

Rio de Janeiro

2020 
Copyright (c) 2020, EdUERJ.

Todos os direitos desta edição reservados à Editora da Universidade do Estado do Rio de Janeiro. É proibida a duplicação ou reprodução deste volume, ou de parte do mesmo, em quaisquer meios, sem autorização expressa da editora.

\section{EdUERJ}

Editora da UNIVERSIDADE DO ESTADO DO RIO DE JANEIRO

Rua São Francisco Xavier, 524 - Maracanã

CEP 20550-013 - Rio de Janeiro - RJ - Brasil

Tel./Fax.: 55 (21) 2334-0720 / 2334-0721

www.eduerj.uerj.br

eduerj@uerj.br

Editor Executivo

Coordenadora Administrativa

Coordenadora Editorial

Assistente Editorial

Coordenador de Produção

Assistente de produção

Supervisor de Revisão

Revisão

Capa

Projeto e Diagramação
João Feres Júnior

Elisete Cantuária

Silvia Nóbrega de Almeida

Thiago Braz

Mauro Siqueira

Érika Neuschwang

Elmar Aquino

João Matorelli

Iris Figueiredo

Júlio Nogueira

Emilio Biscardi

C568 Cidade e campo: olhares de Brasil e Portugal [recurso eletrônico] /

Organização Glaucio José Marafon, Eduarda Marques da Costa. - 1. ed.

- Rio de Janeiro : EdUERJ, 2020.

1 recurso online (306 p) : ePub.

ISBN 978-65-87949-05-5

1. Geografia humana. 2. Geografia urbana. 3. Territorialidade humana. I. Marafon, Glaucio José. II. Costa, Eduarda Marques.

CDU 911.3

Bibliotecária: Thais Ferreira Vieira CRB-7/5302 


\section{Sumário}

Prefácio.

Parte I - Conceitos de cidade e campo - da dicotomia à relaçáo cidade-campo

Capítulo 1 - Cidade e campo: olhares de Brasil e Portugal

Eduarda Marques da Costa e Glaucio José Marafon

Capítulo 2 - Notas sobre as relaçóes cidade e campo: um esforço de síntese na realidade brasileira

Sonale Vasconcelos de Souza e Doralice Sátyro Maia

Capítulo 3 - A possibilidade de levantar dados sobre a percepção espacial do rural e do urbano no Brasil.

Gabriel Bias-Fortes e Glaucio José Marafon

Parte II - Políticas para os territórios rurais, urbanos e espaços metropolitanos

Capítulo 4 - Mundo rural e biodiversidade: a territorialização das políticas públicas de desenvolvimento rural em Portugal

Susana Clemente

Capítulo 5 - Turismo, cultura, criatividade e desenvolvimento local:

casos de estudo em municípios de pequeno porte demográfico em Portugal...... 113

Eduarda Marques da Costa, Larissa de Mattos Alves e Angela Maria Endlich

Capítulo 6 - Política urbana no Brasil: a difícil regulação de uma urbanização periférica

Angela Moulin S. Penalva Santos

Capítulo 7 - Governanças metropolitanas no Brasil: cooperações intergovernamentais e coparticipações instituintes para a sustentabilidade da gestão dos territórios Augusto César Pinheiro da Silva 
Parte III - Temas-chave no quadro dos novos desafios para os territórios

Capítulo 8 - Agricultura em espaço metropolitano: dinâmicas, tipologias e políticas espaciais para a sustentabilidade.

Patrícia Abrantes e Eduardo Gomes

Capítulo 9 - Transporte e Cidades Saudáveis: realidades, políticas e intervenções em Portugal.

Nuno Marques da Costa, Ana Louro e Eduarda Marques da Costa

Capítulo 10 - Mobilidade e segurança em contexto urbano:

contributos para a redução do risco em populaçóes idosas.

Paulo Nuno Nossa e Anabela Mota-Pinto

Capítulo 11 - Atuação da rede de gestão empresarial no território brasileiro no início do século XXI

Paulo Wagner Teixeira Marques e Miguel Angelo Ribeiro

Anexo 1

Anexo 2

Anexo 3 301

Sobre os autores e organizadores 305 


\section{Prefácio}

O presente livro se constitui de uma compilação de textos estruturados em três partes.

A parte I centra-se na discussão dos "Conceitos de campo e cidade - da dicotomia à relação cidade-campo" e como a sua evolução nos leva para os conceitos de rural, urbano e relações rural-urbano. Esta abre com um capítulo de E. Marques da Costa e G. Marafon, de introdução às temáticas, frisando as transformações globais e, mais em particular, as verificadas nas realidades brasileira e portuguesa, com o título do livro: "Cidade e campo: olhares de Brasil e Portugal”.

Seguem-se, ainda na parte I, dois capítulos centrados no caso do Brasil: o capítulo 2, "Notas sobre as relações cidade e campo: um esforço de síntese", de Souza e Maia, discussão que se complementa com o texto do capítulo 3, intitulado "A possibilidade de levantar dados sobre a percepção espacial do rural e do urbano no Brasil”, de G. Bias-Fortes e G. Marafon.

Após a discussão de conceitos e critérios, entramos na parte II do livro, em que se introduz a temática "Políticas para os territórios rurais, urbanos e espaços metropolitanos”. Esta segundo parte inicia-se com o capítulo 4, de S. Clemente, intitulado "Mundo rural e biodiversidade: a territorialização das políticas públicas de desenvolvimento rural em Portugal”, no qual a autora traz para a discussão a orientação da política de desenvolvimento rural na União Europeia, que veio promover novas atividades para além da agricultura, contribuindo para a diversificação funcional e para o seu desenvolvimento.

O capítulo 5, de E. Marques da Costa, L. Matos e A. Endlich, intitulado "Turismo, cultura, criatividade e desenvolvimento local: casos de estudo em municípios de pequeno porte demográfico em Portugal”, reporta três exemplos da realidade portuguesa (os municípios de Montemor-o-Novo, Coruche e Óbidos), mostrando outras alternativas que se colocam ao desenvolvimento dos territórios rurais.

No capítulo 6, de Ângela Santos, intitulado "Política urbana no Brasil: a difícil regulação de uma urbanização periférica”, explica-se de forma detalhada 
a evolução do fenômeno da urbanização na realidade do Brasil e como as políticas relacionadas com o "urbano" foram sendo produzidas de forma a irem se adaptando às aceleradas mudanças ocorridas.

Em seguida, o capítulo 7, de Augusto Silva, com o título "Governanças metropolitanas no Brasil: cooperações intergovernamentais e coparticipações instituintes para a sustentabilidade da gestão dos territórios”, reporta que, para responder às novas formas de organização territorial, a gestão territorial avança para formas multiescalares, envolvendo diferentes entidades político-administrativas que, pelas suas competências, só podem atuar em determinadas configurações territoriais.

A parte III, intitulada "Temas-chave no quadro dos novos desafios para os territórios”, inicia-se com o trabalho de P. Abrantes e E. Gomes. Esses autores apresentam o capítulo 8, "Agricultura em espaço metropolitano: dinâmicas, tipologias e políticas espaciais para a sustentabilidade”, e fazem uma proposta de classificação dos municípios da Região Metropolitana de Lisboa, tendo em conta o tipo de agricultura que pode ser encontrada nos diferentes contextos de urbanização.

Seguem-se dois trabalhos centrados na questão do transporte e mobilidade. O capítulo 9, com o título "Transporte e Cidades Saudáveis: realidades, políticas e intervenções em Portugal”, elaborado por N. Marques da Costa, A. Louro e E. Marques da Costa, traz para cima da mesa a questão do planeamento urbano com vista à promoção de cidades saudáveis e ao papel que o transporte e a mobilidade podem deter nesse processo. O capítulo 10, de P. Nossa e A. Mota-Pinto, continua a problemática da mobilidade. Nesse caso, aplicada ao grupo dos idosos. "Mobilidade e segurança em contexto urbano: contributos para a redução do risco em populações idosas" é um capítulo que retrata o problema do envelhecimento e como a mobilidade condicionada, fomenta o isolamento.

O capítulo 11 encerra a parte III e relaciona-se com a constituição de redes de gestão empresarial. Tendo por base o título de P. Marques e M. Ribeiro, "Atuação da rede de gestão empresarial no território brasileiro no início do século XXI", voltamos à discussão sobre a importância de definir e compreender as formas de organização do território, tema com que iniciamos a presente obra. 
As realidades do Brasil e Portugal, apesar de muito distintas pelas dimensões dos dois países, pelas formas de organização e competências político-administrativas e pelo diferente desenvolvimento das políticas setoriais e territoriais, apresentam aspectos em comum, que aqui serão discutidos. Obrigado a todos os que aceitaram participar deste livro e assim contribuíram para fortalecer o conhecimento geográfico.

Eduarda Marques da Costa - Universidade de Lisboa Glaucio José Marafon - Universidade do Estado do Rio de Janeiro 



\begin{abstract}
Parte I
Conceitos de cidade e campo da dicotomia à relação cidade-campo
\end{abstract}





\section{Capítulo 1 \\ Cidade e campo: olhares de Brasil e Portugal}

Eduarda Marques da Costa

Glaucio José Marafon

\section{Introdução}

As designações cidade e campo têm desde sempre inspirado múltiplas leituras em geografia e sociologia, passando-se de uma abordagem centrada na caracterização e na evolução do campo e da cidade para novas abordagens que, nas últimas três décadas, consideram a emergência de espaços toldados pela urbanização estruturada em torno da acessibilidade. Estes configuram lugares onde se misturam características urbanas e rurais e onde se desenvolvem novas funções e novos padrões de ocupação social e econômica. A presente obra, intitulada Cidade e campo: olhares de Brasil e Portugal, apresenta nos capítulos seguintes um conjunto de onze contributos centrados em temas da geografia, retratados nas realidades dos dois países, cujos conteúdos se estruturam em três partes.

O presente capítulo desenvolve-se em torno de um conjunto de reflexões teóricas de partida baseadas na perspetiva de vários autores internacionais, fazendo o contraponto com a perspetiva apresentada pelos autores dos capítulos desta obra.

\section{Conceitos de cidade e campo - da dicotomia à relação cidade-campo}

A primeira parte do presente livro gira em torno da discussão dos conceitos de cidade e campo, tendo em consideração não só a sua evolução, mas também a importância que assumiu a relação entre estes ao longo dos vários séculos. A passagem de uma realidade em que o campo estava claramente separado da cidade tem na realidade europeia uma expressão mais antiga, mobilizada pelas 
atividades comerciais e de governação impulsionadas pela revolução industrial, que motivou um maciço êxodo do campo para as cidades. No caso da realidade brasileira, os processos conducentes à construção do urbano assumiram uma natureza política muito forte, e a industrialização como motor de crescimento das cidades é um fator mais tardio. O capítulo "Notas sobre as relações cidade e campo: um esforço de síntese na realidade brasileira”, de Souza e Maia, percorre um caminho sobre a literatura, no sentido de compreender as transformações ocorridas entre a cidade e o campo, considerando uma perspetiva marxista e usando um foco sociológico que explica a produção do espaço como sendo um resultado da divisão do trabalho, da expansão do capitalismo e da detenção dos meios de produção, como enfatizaram autores datados da década de 1970, como Lefevre (1970) e Queiroz (1978), citados por Souza e Maia (2019).

Contudo, a leitura dicotômica evoluiu. Autores como Rémy e Voyé (1992) deram um forte contributo para a compreensão das cidades e do fenômeno da urbanização, explicando que o modo como as relações sociais se estruturam é fortemente induzido pela morfologia do espaço em que se reside. Nesse sentido, os autores defenderam que o aumento da acessibilidade determinou a disseminação espacial das funções citadinas e, com elas, novas formas de apropriação dos espaços de residência.

A melhoria da acessibilidade por modo rodoviário e a expansão da posse e da utilização do automóvel vieram a conduzir a integração de novos espaços e a acelerar as transformações na composição e na diversificação das atividades econômicas, dando ao campo características urbanas, nomeadamente na envolvente das cidades, num modelo de ocupação mais dispersa, onde encontramos residências e atividades econômicas consumidoras de espaço, que resultam do processo de desconcentração das cidades. Passamos, assim, da perspetiva campo-cidade para a perspetiva urbano-rural, na medida em que o campo ultrapassa o seu papel de produtor agrícola, vendo expandir novas funções industriais e terciárias e, no caso do campo localizado na envolvente das cidades, expande-se a função residencial, dando lugar a um conjunto de novas relações entre o urbano e o rural (Marques da Costa, 1997).

No caso das áreas urbanas de maior dimensão e pujança funcional, esses fenômenos deram lugar ao que François Ascher $(1998,2005)$ designou de metapolis, um território resultante de processos onde confluiu uma ocupação urbana multipolar estruturada em torno de vias de comunicação e onde os espaços de cariz rural funcionaram como espaços intersticiais de menor densidade, mas 
cuja malha de relações se encontrava plenamente integrada à rede de polos que configuravam as metrópoles (Marques da Costa, 2000).

Anteriormente a essa designação, surgiu o conceito de metropolização, cuja incidência "não se restringe às regiões metropolitanas, já que incorpora as cidades médias, as pequenas e o chamado 'mundo' rural, hoje muito transformado e incorporando urbanidades." (Ferreira et al., 2013, p. 460).

Nesse contexto de mudança na mobilidade e nas decorrentes transformações do território, os critérios estatísticos de classificação das cidades e de urbano-rural, tradicionalmente defendidos pelos Institutos Nacionais de Estatística, sofreram uma necessidade de adaptação, urgindo igualmente efetuar uma reflexão que desenvolvesse critérios de comparabilidade entre os sistemas estatísticos dos vários países, de forma a ter uma leitura coerente da evolução do fenômeno da urbanização nos vários países e regiões do mundo.

O fenômeno de suburbanização característico dos anos 1950 e 1960 na realidade norte americana e europeia é substituído por uma expansão dos espaços periurbanos e rurbanos, cujos critérios de identificação assentam, entre outros, na densidade populacional, no perfil de atividades econômicas e na estrutura de movimentos pendulares. Esses processos foram tratados por autores a propósito das realidades metropolitanas e rurais do Brasil (Coy et al., 2019) e de Portugal (Abrantes, 2011; Loupa-Ramos et al., 2013), tendo estes procurado lançar novas metodologias de classificação dos espaços que contemplassem essas novas categorias de ocupação.

O tópico centrado nas relações urbano-rurais ganha, no quadro europeu, uma relevância assinalável quando, em 1999, é publicado o "EDEC-Esquema de Desenvolvimento do Espaço Comunitário" (em título original: "ESDP European Spatial Development Perspective - Towards Balanced and Sustainable Development of the Territory of the European Union”, EC, 1999), documento que resulta de uma vasta investigação sobre as transformações econômicas, sociais e territoriais no território europeu e da consensualização entre os ministros nacionais que tutelam o ordenamento do território. A sua aprovação em 1999, seguida da aprovação em Tampere, também em 1999, de um Programa de Ação, foi um marco para o início de uma estratégia com vista ao desenvolvimento equilibrado e sustentável do território europeu, destacando-se como primeiro princípio o "Desenvolvimento espacial policêntrico e nova relação cidade-campo" (Ferrão, 2004; Marques da Costa, 2006). 
Nesse documento, foi assumido como fundamental para o equilíbrio territorial a importância de reforçar a parceria entre os territórios urbanos e rurais. Contudo identificaram-se grandes diferenças entre as áreas rurais localizadas junto às grandes cidades e as áreas urbanas localizadas em contexto rural (EC, 1999, p. 66-8), pelo que importava recorrer a critérios e classificações territoriais mais avançadas que as dicotômicas. É nesse contexto que se seguiram de imediato dois estudos suportados pelo Programa ESPON (European Spatial Planning Observatory Network) para o período de 2000 a 2006: um primeiro, cujo objetivo foi apresentar uma tipologia de grandes cidades no quadro europeu (ESPON 1.1.1., Urban Areas as Nodes in a Polycentric Development); e um segundo, cujo objetivo era propor uma tipologia de territórios urbanos e rurais (ESPON 1.1.2. - Urban-Rural Relations in Europe). O estudo "Urban-Rural Relations in Europe” apresentou uma tipologia de seis classes de territórios, cujos critérios de classificação de base eram: densidade populacional, dimensão das cidades e tipos de ocupação do solo extraídos a partir do CORINE Land Cover (Bengs e Schmidt-Thomé, s/d, p. 26).

Paralelamente aos trabalhos referidos, o Eurostat e a OECD investiram também no desenvolvimento de metodologias de classificação dos espaços rurais e urbanos. De uma tipologia inicial de espaços rurais produzida em 1994, cujo objetivo foi dar suporte a um estudo sobre emprego - com uma proposta de três tipos de espaços: áreas rurais remotas, áreas rurais economicamente integradas e áreas rurais intermédias (OECD, 1994, apud Clemente, 2016) -, avançou-se para outras propostas de classificação, sendo que as mais recentes recorrem a um novo tipo de indicadores que se extraem da utilização de imagens de satélite. Os referidos indicadores de imagem, combinados com indicadores estatísticos clássicos, permitem compreender e catalogar melhor as transformações territoriais. Citemos aqui um dos mais recentes documentos de referência, intitulado Methodological manual on territorial typologies, cuja última versão, publicada em 2018, apresenta várias catalogações de territórios: territórios urbanos, áreas costeiras, áreas de montanha e, entre outras, uma tipologia de espaços urbano-rurais - que os divide em: áreas predominantemente urbanas, áreas predominantemente rurais e áreas intermédias.

No caso português, paralelamente à classificação de natureza político-administrativa associada à "Cidade"

Lei 11/82 de 2 de junho. A "Cidade" é uma entidade que se integra no espaço geográfico dos "concelhos. 
de Áreas Urbanas", criada pelo INE em parceria com a Direção Geral do Ordenamento do Território e Desenvolvimento Urbano (DGOTDU) ${ }^{2}$, classificação posteriormente atualizada em 2009 e 2014, em que, apesar de se manterem as três classes de território, a unidade de base desce abaixo da freguesia, respondendo ao critério do Eurostat $^{3}$ (Marques da Costa, 2017).

No caso brasileiro, Rodrigues (2014) apresenta uma proposta de classificação dos municípios brasileiros baseada em dezenove indicadores estruturados em três dimensões (1. Estrutura demográfica, 2. Nível de desenvolvimento e 3. Dinâmica territorial, considerando-se como exemplos de indicadores de cada uma destas a população, o nível ocupacional nos serviços e o peso das migrações pendulares), que, após uma análise fatorial, dão lugar a uma tipologia diversificada de territórios. Segundo Rodrigues, 2014, p 20),

De acordo com esta tipologia, os municípios brasileiros estão classificados em sete categorias, contando com três tipos de urbano: urbano metropolitano, urbano de alta densidade e centros urbanos; três tipos de rural: rural agrícola, rural semiperiférico e rural periférico. Observa-se ainda uma categoria intermédia,

2 Publicação no DR 210/98 de 11/SÉRIE II, de 11/09/1998 - Tipologia das Áreas Urbanas (INE/ DGOTDU, 1998), com três tipos de áreas: as "Áreas Predominantemente Urbanas", as "Áreas Medianamente Urbanas" e as "Áreas Predominantemente Rurais". Eram consideradas "Áreas Predominantemente Urbanas" as:

- freguesias que possuam uma densidade populacional superior a $500 \mathrm{hab} / \mathrm{km}^{2}$ ou que integrem um lugar com população residente igual ou superior a 5.000 habitantes;

- freguesias semiurbanas contíguas às freguesias urbanas, segundo orientaçóes e critérios de funcionalidade/planeamento, sendo consideradas freguesias semiurbanas todas as freguesias não urbanas que possuam densidade populacional superior a 100 e inferior ou a 500 $\mathrm{hab} / \mathrm{km}^{2}$ ou que integrem um lugar com população residente igual ou superior a 2.000 habitantes e inferior a 5.000 habitantes;

- freguesias sedes de concelho com mais de 5.000 habitantes.

${ }^{3} \mathrm{Na}$ atualização de 2014 (Diário da República, 2.a série, n.o 144, de 29 de julho de 2014), passa a ser considerada Área predominantemente urbana (APU) uma freguesia que contemple, pelo menos, um dos seguintes requisitos: 1) o maior valor da média entre o peso da população residente na populaçấo total da freguesia e o peso da área na área total da freguesia corresponde a espaço urbano, sendo que o peso da área em espaço de ocupação predominantemente rural não ultrapassa $50 \%$ da área total da freguesia; 2) a freguesia integra a sede da Câmara Municipal e tem uma população residente superior a 5.000 habitantes; 3 ) a freguesia integra total ou parcialmente um lugar com populaçấo residente igual ou superior a 5.000 habitantes, sendo que o peso da população do lugar no total da população residente na freguesia ou no total da população residente no lugar é igual ou superior a 50\%. 
na qual se observam características urbanas e rurais, por isso denominada de espaços urbano-rurais.

Mas a proposta anterior não elimina as limitações na classificação dos territórios que, mesmo estando na influência de metrópoles, persistem com cariz rural devido ao tipo de atividades e de ocupação do solo existente. Por outro lado, a consideração da escala municipal não permite detectar os diferentes padrões de densidade populacional e de atividades. Essas limitações do sistema estatístico de classificação de urbano e rural, no caso brasileiro, são discutidas no capítulo intitulado "A possibilidade de levantar dados sobre a perceção espacial do rural e do urbano no Brasil”, texto de Bias-Fortes e Marafon, que refere a insuficiência dos critérios do IBGE na classificação dos territórios em rural e urbano. Os autores vêm salientar o interesse de introduzir uma nova questão no Censo Populacional dirigida ao residente, que classifique a sua perceção sobre o seu local de residência, complementando os critérios estatísticos existentes.

\section{Políticas para os territórios rurais, urbanos e espaços metropolitanos}

A questão dos conceitos e das respectivas metodologias para classificação dos territórios em categorias que vão para além da classificação dicotômica, ganha crescente importância, na medida em que servem de base à seleção dos territórios onde são implementadas as políticas e onde se tutelam diferentes organizações de governança. Ou seja, não só as competências dos territórios são distintas, como também as políticas e o orçamento que a estes destinamos são diferentes, demonstrando-se a pressão em obter critérios claros na classificação em diferentes categorias de ocupação.

O capítulo de Clemente, intitulado "Mundo rural e biodiversidade: a territorialização das políticas públicas de desenvolvimento rural em Portugal”, traz para a discussão a orientação da política de desenvolvimento rural na União Europeia, que veio promover novas atividades para além da agricultura, contribuindo para a diversificação funcional e para o seu desenvolvimento e confirmando a separação do rural em relação ao campo e à função agrícola. Nessa afirmação de outras dimensões, falemos da dimensão ambiental, em particular a centrada na conservação da natureza e da biodiversidade, que encontrou nas políticas da União Europeia outro foco para as políticas de desenvolvimento rural. Aqui se destacam, por um lado, a criação da Rede Natura 2000, criada em 
1992, diretamente vocacionada para "aves" e "habitats", por outro, a reforma da Política Agrícola Comum (PAC), de 1992, momento em que se assistiu à introdução da componente ambiental numa ótica de proteção. Outro passo importante deu-se em 1999, quando é criada a Política de Desenvolvimento Rural como um dos pilares da PAC.

Paralelamente à valorização da componente ambiental no contexto do espaço rural, o turismo, centrado no aproveitamento dos recursos locais decorrentes da cultura e do patrimônio, surge também como uma nova alternativa de política para o desenvolvimento dos pequenos municípios em contexto rural (Marafon, 2014). A cultura tornou-se, assim, um recurso importante refletido na utilização do patrimônio cultural nas trajetórias de desenvolvimento local da União Europeia (Durmaz et al., 2010).

Segundo o relatório da OECD de 2009, dedicado ao "Impacto da Cultura no Turismo", existe uma clara relação entre turismo, cultura e valorização do patrimônio, e, como aponta Richards (2013), essa relação não pode ser dissociada da criatividade, fazendo a ponte para as cidades criativas e para o turismo criativo. Para além do patrimônio cultural, encontramos outras manifestações culturais que são igualmente mobilizadoras do desenvolvimento turístico. É o caso dos eventos culturais onde se incluem festivais de música, teatro e afins, bem como a realização de feiras ou de concursos de natureza diversificada, atividades que podem surgir de forma combinada (ex. mostras de gastronomia, feiras de artesanato ou outros eventos ligados à história local, como as feiras medievais). Os eventos transformaram-se, assim, num fator muito poderoso de desenvolvimento, pois fornecem a atividade e a animação necessárias para ativar espaços criativos. Richard (2013) refere que, por meio de programação cuidadosa e seleção de portfólio de eventos, é possível ligar a criatividade da população local ao setor cultural e criativo e aos visitantes. Marques da Costa, Alves e Endlich, em texto intitulado "Turismo, cultura, criatividade e desenvolvimento local: casos de estudo em municípios de pequeno porte em Portugal”, incluído no presente volume, reportam três exemplos da realidade portuguesa dos municípios de Montemor-o-Novo, Coruche e Óbidos.

Fazendo a transição entre as orientações de política dos espaços rurais para as dos espaços urbanos e, mais em particular, metropolitanos, podemos salientar o texto incluído neste volume, de Ângela Santos, intitulado "Política urbana no Brasil: a difícil regulação de uma urbanização periférica”, onde se explica de forma detalhada a evolução do fenômeno da urbanização na realidade do Brasil 
e como as políticas relacionadas com o "urbano" foram sendo produzidas de forma a irem se adaptando às aceleradas mudanças ocorridas. A. Santos discute a evolução da urbanização na realidade brasileira e que respostas, em termos de políticas urbanas, foram sendo apresentadas ao longo dos últimos cinquenta anos. A autora refere que a acelerada urbanização do Brasil não foi acompanhada de políticas urbanas de ordenação do território, situação que se tornou mais crítica nas últimas décadas, onde a massificação do êxodo rural no Brasil alimentou uma expansão urbana periférica, que deu lugar a metrópoles não planeadas, carentes de habitação, equipamentos e acessibilidades. Essa ideia foi também defendida por outros autores que afirmam a década de 1970 como o marco para o "crescimento desordenado", secundado com a criação de programas alternativos que se baseavam na autoconstrução (Ferreira et al., 2013). Posteriormente, a solução Minha Casa Minha Vida, mostra-se insuficiente pela excessiva penetração do mercado privado na produção de habitação social.

Quer o texto de A. Santos, quer o de Augusto Silva, relevam, para a importância da política urbana, adaptar-se aos territórios resultantes das novas formas de organização polinucleadas e ao aumento de fluxos entre esses polos. E a gestão territorial tem de responder a essas novas configurações. Silva, com o título "Governanças metropolitanas no Brasil: cooperações intergovernamentais e coparticipações instituintes para a sustentabilidade da gestão dos territórios”, reporta que, para responder às necessidades e aos fluxos existentes, a gestão territorial tem avançado para formas multiescalares, envolvendo diferentes entidades político-administrativas que, pelas suas competências, só podem atuar em determinadas configurações territoriais. Para o autor, a emergência de novos arranjos de governança multinível é a resposta para os distintos problemas que caracterizam as regiões urbanas funcionais, definidas em torno das deslocações pendulares.

Hall (2002), Sassen (2002) e Scott et al. (2002), em obra editada por Scott (2002), discutem o conceito de cidade-região global e o desafio de reestruturação da governança desses territórios. Mas esse fenômeno está longe de se restringir à cidade-região global e aos contextos de metropolização. A organização funcional em territórios estruturados em torno de pequenas e médias cidades, quer em contexto de urbanização dispersa, quer em contexto territorial rural e de baixa densidade, apresenta as mesmas características, como se pode citar para o caso europeu, para o caso português (Marques da Costa e Marques da Costa, 2013) e para o contexto da América Latina, onde se inclui a realidade brasileira (Rua, 2006; Maturana et al., 2017). 


\section{Temas-chave no quadro dos novos desafios para os territórios}

A parte terceira do presente livro introduz-nos temas nos quais têm ocorrido mudanças rápidas, gerando novos desafios para a qualidade de vida das populações: o desenvolvimento da agricultura em contexto urbano e periurbano; a questão da mobilidade urbana pela sua relação com as políticas de desenvolvimento urbano saudável; a problemática do envelhecimento populacional nas cidades e algumas das consequências que operam; e a questão da organização empresarial em rede, como resultado da globalização do capital e dos mercados, mas também assumida pelas empresas como uma estratégia para atingir uma maior competitividade.

A temática da agricultura em espaço urbano ou periurbano, embora tenha sido um assunto tomado pela FAO desde a década de 1990 (Smit et al., 1996), numa perspetiva que conferia à agricultura o papel de fonte de produção alimentar em áreas de forte concentração populacional e, ao mesmo tempo, fonte de emprego e rendimento, pela possibilidade de se desenvolver em regime de pluriatividade.

Nos últimos anos, a urbanização difusa fez aumentar o valor do solo, e a agricultura perdeu rendibilidade para a atividade imobiliária (Abrantes et al., 2013). Ao uso fragmentado do solo ou mesmo ao abandono da produção, juntou-se uma ocupação desordenada, onde o automóvel é rei nas deslocaçóes das famílias, nos consumos de energia e nas emissóes de $\mathrm{CO}_{2}$, contribuindo para a insustentabilidade dos territórios. Nesse contexto, a temática da agricultura urbana foi crescendo em importância pela associação feita ao seu contributo para o desenvolvimento sustentável (Van Tuijl et al., 2018) e reconhecendo o seu valor ambiental, econômico, social e na saúde e bem-estar. Seguindo Tornaghi (2014), a agricultura urbana e periurbana é multidimensional, envolvendo diferentes técnicas de produção (ex: hidroponia), objetivos (ex: consumo, venda, educação) e formas de governança (ex: hortas comunitárias). Essa nova perspetiva tem expressão não só nos instrumentos de ordenamento territorial de escala regional, mas também nos planos diretores e em diretrizes urbanas delineadas com base nos princípios dos movimentos urbanísticos de eco-cidade, urbanismo verde e urbanismo sustentável (Lehmann, 2010). Aqui, combina-se a triologia " $3 \mathrm{~F}$ - food, farm and forestry" (alimentação, agricultura e floresta) como elementos promotores do equilíbrio dos ecossistemas e das cidades, contribuindo para a segurança alimentar (UN Food and Agriculture 
Organization, 2016) e concertando uma verdadeira relação urbano-rural no âmbito do paradigma da sustentabilidade social e ambiental.

Entre os 15 princípios do Urbanismo Verde encontram-se dois com maior ligação à dinâmica rural e à questão da agricultura no quadro urbano, promotores de bacias alimentares de proximidade: "A Cidade que maximiza a paisagem, os jardins e a biodiversidade" e "A Cidade com produção alimentar segura e biológica local” (Lehmann, 2010).

Abrantes e Gomes, com texto intitulado "Agricultura em espaço metropolitano: dinâmicas, tipologias e políticas espaciais para a sustentabilidade”, incluído nesta obra, fazem uma proposta de classificação dos municípios da Região Metropolitana de Lisboa, tendo em conta o tipo de agricultura que pode ser encontrada nos diferentes contextos de urbanização. Entre as conclusões destacam-se os nove grupos a que se chegou, agregados em três tipos de territórios (i) agrícola urbano; ii) agrícola periurbano; e iii) agrícola rurbano), praticando três tipos de atividades (i) agricultura de lazer; ii) agricultura intensiva e, em alguns casos, combinada com lazer; e iii) agricultura em declínio), resultados que se configuram como material de suporte à formulação de políticas públicas sustentáveis.

O segundo grande desafio dos territórios, nomeadamente dos espaços urbanos, relaciona-se com a mobilidade. O título "Transporte e Cidades Saudáveis: realidades, políticas e intervenções em Portugal”, elaborado por N. Marques da Costa, A. Louro e E. Marques da Costa, vem no seguimento das preocupações com a sustentabilidade, traduzida também num planeamento urbano voltado para a construção de comunidades mais sustentáveis e inclusivas capazes de proporcionar melhor qualidade de vida aos seus residentes. Um dos movimentos urbanísticos que mais se aproxima dessa perspectiva é o "Movimento Cidades Saudáveis", que considera que a saúde é influenciada pelas condições de vida, de trabalho, do ambiente físico e socioeconômico dos indivíduos. Fonte de poluição e de sinistralidade rodoviária, elemento de acesso aos serviços, emprego e habitação, o transporte e a mobilidade são, por isso, dimensões fundamentais a ter em conta na construção de cidades saudáveis. Apesar das orientações dadas pela OMS para a elaboração do "Projeto Cidade Saudável” nas várias realidades territoriais, só os municípios aderentes ao movimento é que partilham a metodologia, procurando integrar a saúde em todas as políticas.

O texto seguinte, de P. Nossa e A. Mota-Pinto, continua a problemática da mobilidade, nesse caso aplicada ao grupo dos idosos, um grupo em ascensão rápida no contexto demográfico europeu. "Mobilidade e segurança em contexto 
urbano: contributos para a redução do risco em populações idosas" é um capítulo que retrata o envelhecimento, identificando a sua incidência e buscando soluções que contribuam para o bem-estar das populações. $\mathrm{O}$ avanço da idade retira ao idoso a sua capacidade de mobilidade, situação que se agudiza, quer por razões econômicas (baixo rendimento, condicionamento de deslocações para fins de consumo e lazer), quer por razóes físicas (decorrentes de doença ou maior fragilidade que condicionam as deslocações), quer ainda por outras razões menos evidentes, como sejam as preocupações com a violência e a segurança em determinadas horas do dia. A mobilidade condicionada fomenta o isolamento, e o combate a essas situações é uma das metas a atingir para o planeamento de cidades saudáveis e inclusivas. As soluções são várias, destacando-se as ligadas ao planeamento de ambientes amigos do idoso, bem como no fomento de uma estratégia de prevenção da saúde que suporte um futuro envelhecimento ativo e saudável das populações (Green, 2012).

O quarto desafio aqui apontado relaciona-se com a constituição de redes de gestão empresarial, tendo por base o título de P. Marques e M. Ribeiro, "Atuação da rede de gestão empresarial no território brasileiro no início do século XXI”. Com esse texto, voltamos à discussão sobre a importância de compreender as formas de organização do território. Para além do que podemos observar como nós de um sistema urbano, temos uma estrutura invisível de fluxos de capital e produção, que usam as novas tecnologias para atravessar distâncias físicas e que permitem a constituição de redes que nem sempre têm proximidade física. Nesse contexto, as cidades assumem-se como os territórios onde as infraestruturas e equipamentos permitem o estabelecimento desses fluxos de capital e produção, consumando as ligações entre a economia e o território (Correia, 2018). A competitividade do tecido econômico e territorial está amplamente relacionada com a capacidade de estabelecer esses fluxos com outros polos.

A realidade do Brasil mostra a existência de um conjunto de cidades onde essas questões ainda não são preocupação e, como os autores comentam, a malha de cidades conectadas está territorialmente concentrada, contribuindo para acentuar as disparidades de desenvolvimento territorial.

Esta obra assume-se como um percurso por conceitos e temas da geografia comuns aos territórios, mas onde, apesar de tudo, encontram-se singularidades, quer na realidade brasileira, quer na realidade portuguesa, que procuramos aqui retratar. 


\section{Referências}

ABRANTES, Patrícia. La métropolisation au Portugal: processus et politiques spatiales. Lisboa: Universidade de Lisboa, Centro de Estudos Geográficos, 2011. Disponível em: https://repositorio.ul.pt/handle/10451/38909. Acesso em: 30 jul. 2019. et al. "Lezíria do Tejo: agriculture et étalement urbain aux marges métropolitaines de Lisbonne". Cabiers Agricultures, v. 22, n. 6, p. 526-34, 2013.

ASCHER, F. Métapolis: acerca do futuro da cidade. Oeiras: Editorial Celta, 1998. . Les nouveaux principes de l'urbanisme. Quetigny: Editorial del Aube, 2005.

BENGS, C. e SCHMIDT-THOMÉ, K. (eds.).ESPON 1.1.2. - Urban-Rural Relations in Europe, Luxemburg, ESPON Coordination Unit, s/d. Disponível em: https:// www.espon.eu/programme/projects/espon-2006/thematic-projects/urban-rural-relations-europe. Acesso em: 30 nov. 2019.

CLEMENTE, Susana. Politicas de desenvolvimento em áreas rurais classificadas: o caso português (tese). Universidade de Lisboa, 2016.

CORREA. Caminhos paralelos e entrecruzados. São Paulo: Ed. Unesp, 2018.

COY, M. et al.. "Metropolitan Regions: challenges for sustainability and governance of periurban areas in Brazil”. Confins (on-line), n. 38, 2018. Disponível em: http:// journals.openedition.org/confins/16904.. Acesso em: 15 dez. 2019.

DOMINGUES, A. Cidade e democracia. 30 anos de transformação urbana em Portugal. Lisboa: Editorial, Argumentation, 2006.

DURMAZ, B. et al.. "Creativity, culture tourism and place-making: Istanbul and London film industries". International Journal of Culture, Tourism and Hospitality Research, v. 4, n. 3,.2010.

EUROPEAN COMMUNITIES. ESDP European Spatial Development Perspective Towards Balanced and Sustainable Development of the Territory of the European Union, Office for Official Publications of the European Communities, Luxembourg, 1999. EUROSTAT. Methodological manual on territorial typologies. EU, Luxemburg. Disponível em: https://ec.europa.eu/eurostat/statistics-explained/index. php?title=Territorial_typologies_manual. Acesso em: 15 dez. 2019.

FERRÃO, J. “A emergência de estratégias transnacionais de ordenamento do território na União Europeia: reimaginar o espaço europeu para criar novas formas de governança territorial?’. Revista EURE, v. 30, n. 89, p. 43-61, maio 2004.

FERREIRA, A. et al.. "Metropolização do espaço: gestão territorial e relações urbano-rurais”, 2013. Disponível em: https://www.e-publicacoes.uerj.br/ index.php/geouerj/article/view/14408. Acesso em: 15 dez. 2019. 
GASPAR, J. “Cidades Médias e Cidades Intermédias: novas funções territoriais e novas formas urbanas em Portugal”. In BELLET, C. e LLOP.J. (eds.). Ciudades Intermedias: urbanización y sostenibilidad. Lleid: Editorial Milenio, 2000, p. 125-40.

GREEN, G. "Age-friendly cities of Europe". Journal of Urban Health: Bulletin of the New York Academy of Medicine, v. 90, Sup. p1, apud SCOTT, A. J. Global City-Regions: trends, theory, policy. Oxford University Press, Now York, 2002, p. 59-77.

INSTITUTO NACIONAL DE ESTATÍSTICA (INE) - DGOTDU. Tipologia das áreas urbanas. Lisboa: INE-DGOTDU, 1998.

LEHMANN, S. Theprinciples of green urbanism: transforming the city for sustainability. Londres: Earthscan, 2010.

LOUPA-RAMOS, I. et al. "Peri-urban landscapes in metropolitan areas: using transdisciplinary research to move towards an improved conceptual and geographical understanding". Proceedings AESOP-ACSP Joint Congress, Dublin, 2013.

LOURO, A. et al. "Sustainable urban mobility policies as a path to healthy cities - the case study of LMA, Portugal”. Sustainability, v. 11, n. 10, 2019.

MARAFON, G. J. “Territorialidades, ruralidades e as relações campo-cidade/Territorialities, ruralities and country-city relationship". Campo-Território, Revista de Geografia Agrária, v. 9, n. 18, 2014. Disponível em: http://www.seer.ufu.br/index. php/campoterritorio/article/view/26897. Acesso em: 15 nov. 2019.

MARQUES DA COSTA, E. "Cidades médias: contributos para a sua definição". Finisterra, v. 37, n. 74, 13 dez. 2002. Disponível em: http://revistas.rcaap.pt/finisterra/ article/view/1592. Acesso em: 30 jul. 2019.

. "Capítulo 4 - Ordenamento do Território - Alínea 4.2. - A Escala Europeia". IN GASPAR, J. e SIMÕES, J. M. (coords.). Geografia de Portugal: planeamento e ordenamento do território. Lisboa: Círculo de Leitores, 2006, p. 260-67.

e MARQUES DA COSTA, N. "Relações entre urbano e rural no quadro das novas mobilidades em áreas rurais - o caso da Beira Interior". In CAVACO, C. Atas do Seminário Internacional Repensar Portugal na Europa:perspetivas de um pais periférico. Estudos para o Planeamento Regional e Urbano. Lisboa: Centro de Estudos Geográficos, Universidade de Lisboa, 2002, n. 55, p. 158-76.

. "As pequenas e médias cidades portuguesas: dinâmicas demográficas e funcionais nos últimos quarenta anos". In MATURANA, Francisco et al. (eds.). Sistemas urbanos y ciudades medias en Iberoamérica. Santiago: Serie GEOlibros, Pontificia Universidad Católica de Chile, 2017, 258-300.

e ___. "Polycentrism, functional urban regions and labor mobility in Portugal - contradictions between sustainable development objectives and unsustainable patterns of mobility". 53rd ERSA Congress: Regional Integration: Europe, the Mediterranean and the World Economy, Palermo, ago. 2013.

MATURANA, F. et al. (eds.). Sistemas urbanos y ciudades medias en Iberoamérica. Santiago: Serie GEOlibros, Pontificia Universidad Católica de Chile, 2017. 
OECD. Territorial Indicators for Employment. Paris: OECD, 1994.

. The impact of culture on tourism. Secretary-General of the OECD, 2009.

RÉMY,J. e VOYÉ, L. A cidade: rumo a uma nova definição? Porto: Afrontamento, 1992.

RICHARDS, G.. "Tourism development trajectories: from culture to creativity?”. Tourism \& Management Studies, n. 6, p. 6-15, 2009.

. "Creativity and tourism in the city". Current Issues in Tourism, 2013. Disponível em: http://dx.doi.org/10.1080/13683500.2013.783794. Acesso em: 25 ago. 2019 RODRIGUES, João Freire. “O rural e o urbano no Brasil: uma proposta de metodologia de classificação dos municípios”. Análise Social, n. 211, p. 430-56, jun. 2014. Disponível em: http://www.scielo.mec.pt/scielo.php?script=sci_arttext\&pid=S0003$-25732014000200008 \& \operatorname{lng}=$ pt\&nrm=iso. Acesso em: 15 dez. 2019.

RUA, J. "Urbanidades no rural: o devir de novas territorialidades". Campo-Território, Revista de Geografia Agrária, v. 1, n. 1, p. 82-106, fev. 2006. Disponível em: https://repositorio.observatoriodocuidado.org/jspui/bitstream/ handle/1823/1/11781-43706-1-PB.pdf. Acesso em: 15 dez. 2019.

SASSEN, S. “Global Cities and Global City-Regions: a comparison”. In SCOTT, A. J. Global City-Regions: trends, theory, policy. Oxford/Nova York: Oxford University Press, 2002, p. 78-95.

SCOTT, A. J. et al.. "Global City-Regions". In . Global City-Regions: trends, theory, policy. Oxford/Nova York: Oxford University Press, 2002, p. 11-31.

SMIT, J. et al. Urban agriculture: food, jobs and sustainable cities. Nova York: Publication Series for Habitat II, United Nations Development Programme (UNDP), 1996, v. I. TORNAGHI, Chiara. "Critical geography of urban agriculture". Progress in Human Geography, v. 38, n. 4, p. 551-67, 2014. Disponível em: https://journals.sagepub. com/doi/pdf/10.1177/0309132513512542. Acesso em: 30 jul. 2019.

UN FOOD AND AGRICULTURE ORGANIZATION. State of the World's Forests 2016. Forests and agriculture: land-use challenges and opportunities. Roma: FAO, 2016.

VAN TUIJL E. et al.. "Opportunities and challenges of urban agriculture for sustainable city development”. European Spatial Research and Policy, n. 25, p. 5-22, 2018. 


\title{
Capítulo 2 \\ Notas sobre as relações cidade e campo: um esforço de síntese
}

\author{
Sonale Vasconcelos de Souza \\ Doralice Sátyro Maia
}

\section{Introdução}

Discutir sobre a relação cidade e campo é uma tarefa complexa, pois esse tema pode ser abordado a partir de vários vieses diferentes ${ }^{1}$. Esse texto foi originalmente produzido em momentos diversos, pois o tema constituiu a temática de pesquisas anteriores e que ora recuperamos e reunimos, atualizando a nossa discussáo.

Além disso, vale lembrar que se trata de uma relação que, ao longo do tempo, devido à intensificação da divisão do trabalho e à modernização do campo, tem passado por várias transformações que têm contribuído para o surgimento de novas formas e novos conteúdos. Williams (2011 [1973], p. 471), buscando entender as mudanças ocorridas no século XVIII, na Inglaterra, assevera que:

O campo e a cidade são realidades históricas em transformação tanto em si próprias quanto em suas inter-relações. Temos uma experiência social concreta não apenas do campo e da cidade, em suas formas mais singulares, como também de muitos tipos de organizações sociais e físicas, intermediárias e novas.

1 Referimo-nos às pesquisas de mestrado de Sonale Vasconcelos (2013) e de Doralice Maia (1994), à tese de Doralice Maia (2000), além de artigos e trabalhos publicados que tratam da temática. 
Williams (2011 [1973]) tem como objetivo compreender as modificações que estavam ocorrendo na passagem do século XVIII para o século XIX na Inglaterra. Para isso, utiliza uma abordagem histórica social e literária. A partir da citação anterior, podemos notar que o autor do livro $O$ campo e a cidade na história e na literatura dá ênfase à perspectiva histórica como um ponto crucial para se entender as transformaçôes ocorridas entre a cidade e o campo. Visando a entender o "presente", ele retorna ao passado, utilizando obras literárias. Tal perspectiva corresponde ao que Mauricio de Abreu denominou de "presente de então", ou de um "presente histórico", já trabalhado por outros autores como Darby (Abreu, 2000, p. 18).

O movimento de análise realizado por Williams, que se caracteriza pelo constante regresso ao passado para compreender o presente, é chamado por ele de "escada rolante". O autor propóe que esse movimento pode ser uma pista importante para o entendimento dos fatos. Dessa maneira, com o intuito de elaborar uma análise acerca da relação cidade-campo, pretendemos voltar ao passado para decifrar como ocorreu a formação das duas concretudes espaciais, cidade e campo, e como se apresentaram ao longo do tempo, para expressarmos algumas ideias sobre elas na sociedade contemporânea.

A cidade e o campo têm características próprias, tanto em relação ao que é produzido quanto ao conteúdo das relaçôes sociais e culturais. No entanto entendemos que um só pode ser analisado a partir do outro, ou levando em consideração a relação entre ambos. A relação cidade-campo, embora apresente semelhanças em diferentes contextos históricos e espaciais, em cada espaço-tempo, manifestam características únicas, que são resultados da convergência de fatores internos e externos. É importante frisar que, em diferentes países, essa relação não se apresenta com as mesmas características, e em regióes e cidades de um mesmo país, como o Brasil, tal relação tem particularidades.

Nesse sentido, ressaltamos que, para analisar a relação cidade-campo, devemos partir da compreensão do processo histórico, pois, só por meio do seu entendimento, poderemos esclarecer a realidade atual. Lefebvre (1991 [1969], p. 184) afirma que, para "conhecer um objeto ou um fenômeno é [necessário] justamente não considerá-lo como sendo isolado, não deixá-lo passivamente no hic et nunc, no aqui e no agora. É investigar suas relaçôes, suas causas". Para esse autor, assim como o conhecimento, a realidade está em constante movimento, por isso é imprescindível retornar ao passado para compreender o período atual. Assim, apresentaremos uma síntese de como se processou a 
relação cidade-campo no transcurso histórico e, em seguida, analisaremos as peculiaridades dessa relação no contexto histórico brasileiro.

\section{Relaçáo cidade-campo a partir da divisão do trabalho}

Para dialogar sobre a relação cidade-campo, nossa investigação partiu dos autores que refletiram sobre tal relação, mostrando que é imprescindível abordar a divisão do trabalho, pois, a partir dela, é possível conhecer o papel que a cidade e o campo desempenharam ao longo do tempo histórico.

No transcurso do tempo histórico, a separação das configurações espaciais cidade e campo, e, com ela, a divisão do trabalho, sofreu modificações, e a sua intensidade dependia, por sua vez, do ritmo de desenvolvimento das forças produtivas. Como escreveu Neil Smith (1988), "a separação da cidade e do campo é, por si mesma, um produto da divisão social do trabalho, mas vem a se tornar o fundamento como dizia Marx para a divisão do trabalho" (Smith, 1988, p. 164-5).

$\mathrm{Na}$ literatura da economia clássica, Adam Smith, na obra Riqueza das nações, no livro 3, elabora um estudo sobre a origem da divisão do trabalho, portanto, da divisão do trabalho entre campo e cidade. Aqui, a função do campo é a de fornecer os meios de subsistência e os materiais de manufatura para a cidade, ao mesmo tempo que esta fornece àquele parte do produto manufaturado. $\mathrm{O}$ autor também revela que toda a riqueza e a subsistência da cidade provêm do campo, chamando atenção para que, dessa revelação, não se conclua que por isso o ganho da cidade é sinônimo da perda do campo. E define: "a cidade é uma feira, ou mercado, contínuo, ao qual concorrem os habitantes do campo para trocar seu produto bruto pela manufatura [...]" (Smith, 1986, p. 158).

Segundo Marx e Engels (2007 [1932]), antes do surgimento da agricultura no período neolítico, havia apenas grupos organizados em forma de sociedade tribal, na qual não havia diferença entre cidade e campo, e a divisão do trabalho era pouco desenvolvida, pois se limitava a uma divisão social entre membros da família ou da tribo. Sabe-se que o excedente alimentar possibilitou que as comunidades se fixassem em determinado local e que fossem desenvolvidas outras atividades relativas a funções administrativas, políticas, militares e à elaboração do conhecimento e que, a partir de então, o desenvolvimento das forças produtivas provocou uma divisão territorial do trabalho e originou espaços diferenciados de produção: a cidade e o campo. 
Assim, considera-se o estabelecimento da divisão do trabalho entre agricultura e a indústria e comércio como princípio para a constituição da denominada cidade capitalista, ou ainda, parte-se do princípio de que a origem da economia urbana dá-se com o surgimento da divisão territorial do trabalho entre campo e cidade, com a divisão dos poderes e de atividades das duas formas espaciais, como bem escrevem Marx e Engels (1984, p. 64):

A cidade é já a realidade da concentração da população, dos instrumentos de produção, do capital, dos prazeres, das necessidades, ao passo que o campo torna patente precisamente a realidade oposta, o isolamento e a solidão. $\mathrm{O}$ antagonismo entre cidade e campo só pode existir no quadro da propriedade privada.

Nesse sentido, é necessário examinar como a relação entre a cidade e o campo se manifestou em contextos históricos diferentes, tendo em vista que, em determinados momentos, o campo demonstrou ser dominante, social e economicamente, e, em outros, a cidade assumiu esse papel. Lefebvre (2001, p. 68) afirma que a relação cidade-campo "mudou profundamente no decorrer do tempo histórico, segundo as épocas e os modos de produção: ora foi profundamente conflitante, ora mais pacífica e perto de uma associação. Mais ainda, numa mesma época manifestam-se relações bem diferentes".

Esse autor (1999a [1970]), ao mostrar como se deu o processo de urbanização ao longo de diferentes períodos históricos, aborda como tal processo provocou modificações tanto na cidade quanto em sua relação com o campo. Assim, propõe que se analisem, a partir de uma concepção ampla, três grandes épocas históricas: “a rural, a industrial e a urbana” (1999a [1970], p. 35). Na rural, já se verificava uma visível divisão entre cidade e campo. Entretanto, nessa época, a cidade e o campo passaram por vários momentos diferentes: o primeiro, em que a cidade se caracterizava como política; o segundo, quando houve uma retração da cidade e um amplo domínio do campo; e o terceiro, em que o comércio passou a ser uma função importante na/da cidade.

$\mathrm{Na}$ cidade política, característica da Antiguidade, embora houvesse uma divisão do trabalho entre cidade e campo, a cidade mantinha uma relação complementar e harmônica com os territórios circunvizinhos e "organizava, dominava, protegia, administrava, explorava um território, com os camponeses, os habitantes dos vilarejos, os pastores, etc." (Lefebvre, 1999b, p. 40). As cidades podiam ser consideradas como obras, pois o valor de uso predominava sobre o 
valor de troca, e os costumes das pessoas ainda eram mais importantes do que a produção e o consumo. Lefebvre (1969, p. 138) descreve como se caracterizava a cidade e como se dava sua relação com o campo nesse período histórico:

Cada cidade é uma obra e também cada casa. Tudo nela se mistura e se une: objetivos, funções, formas, prazeres, atividades. [...] Entre o campo, as ruas e as casas, não há corte nem confusão; passa-se dos campos ao coração do burgo e das habitações por uma sucessão ininterrupta: árvores, jardins, pórticos e pátios, animais.

No período medieval, com a queda do Império Romano, a maioria das cidades passou por um período de “adormecimento". Nessa época, o campo, organizado em feudos, tinha um maior adensamento populacional e manifestava-se de modo mais dinâmico e autônomo do que as cidades. Contudo a cidade não deixa de existir e tem uma significativa importância, como bem expôs Le Goff (1992). A cidade antiga, onde, antes, o cotidiano se dava a partir do valor de uso, começa a ser superada pela cidade comercial baseada na troca e no comércio (Lefebvre, 2001).

É então a partir da divisão social do trabalho que a relação campo-cidade compõe o movimento de antítese. Essa oposição, com a expansão da indústria moderna e quando se destitui o campo cada vez mais das atividades não agrícolas, passando a ser ruralizado ${ }^{2}$, parece ser diluída na concretização da vitória da cidade sobre o campo a partir da industrialização da agricultura, ou da urbanização do campo. Como afirma Neil Smith (1988, p. 165), apoiando-se na obra Grundrisse, de Karl Marx: "A urbanização do campo, através da industrialização da agricultura, é hoje uma realidade indiscutível e algo que Marx previu”.

O intenso processo de industrialização provocou o crescimento do êxodo rural e aumentou a concentração populacional nas cidades. Por isso, a cidade industrial caracterizou-se por sua intensa expansão sobre o campo. A partir de então, houve uma explosão da cidade tradicional ${ }^{3}$. Esse movimento, chamado

2 Ou seja, "[...] o campo se transforma em agricultura, i.e., indústria separada de alimentos e matérias-primas, dividida, por sua vez, em vários tipos especializados de cultivos, distritos, etc." (Merrington, 1977, p. 172).

3 Conforme Lefebvre (2001), cidade tradicional está relacionada à cidade anterior ao processo de industrialização, portanto caracteriza-se como uma cidade concentrada, única, que também pode corresponder à cidade histórica. 
por Lefebvre (2001) de implosão-explosão, é provocado pela intensificação da urbanização proporcionada pelo processo de industrialização.

$\mathrm{Na}$ era industrial, verifica-se a 'absorção' do campo pela cidade (localização das primeiras indústrias, obtenção de matérias-primas, migração) e a 'explosão' da cidade no campo (extensão do tecido urbano, invasão do campo pela tecnologia, modo de vida e símbolos da cidade, expansão da troca e da mercadoria) (Sobarzo, 2006, p. 71).

A partir de então, a divisão do trabalho, que estabelecia a produção local entre o campo e a cidade, com o desenvolvimento das forças produtivas e da indústria, tornou-se mais complexa, pois passou a organizar tanto o trabalho nos estabelecimentos produtivos (divisão técnica do trabalho) da cidade e do campo quanto a produção e o intercâmbio entre diferentes cidades e nações. Desse modo, o capitalismo passou a explorar cada local de maneira diferenciada conforme seus interesses. Essa progressão da divisão do trabalho é visível no pensamento de Marx e Engels (2007 [1932], p. 47, grifos dos autores), quando afirmam:

A divisão do trabalho no interior de uma nação leva, no princípio, à divisão do trabalho industrial e comercial do trabalho agrícola, e com isso à divisão entre cidade e campo e à oposição entre os interesses de ambos. Seu desenvolvimento posterior leva à divisão entre trabalho comercial e industrial. Ao mesmo tempo se desenvolvem sempre, através da divisão de trabalho no interior desses diferentes setores, diferentes seções entre os indivíduos atuando em conjunto em um determinado trabalho. A posição dessas seções individuais umas contra as outras é condicionada pelo modo de operação do trabalho agrícola, industrial e comercial. As mesmas condições mostram-se, em caso de intercâmbio desenvolvido, nas relações de diferentes nações umas com as outras.

Na linha temporal apresentada por Lefebvre (1999a [1970]), um outro período histórico corresponde ao que denomina sociedade urbana - corresponde à sociedade atual, resultante da implosão-explosão da cidade e em que as relações de produção se modificaram, todavia ainda não foram totalmente transformadas. Segundo o autor, estamos num período em que a distinção entre cidade e campo tende a ser superada, contudo isso não implica o desaparecimento das atividades 
agrícolas. Nesse sentido, o que caracteriza cada unidade espacial (a cidade e o campo) permanece, mas a relação entre ambas se transforma, e as formas espaciais se mesclam, surgindo novos conteúdos entre elas. $\mathrm{O}$ modo de produção capitalista explora ao máximo o que está disponível, por isso que aparecem cada vez mais "novas" atividades econômicas, como a agroindústria e o turismo rural, que misturam aspectos do campo e da cidade.

Queiroz (1978), já na década de 1970, demonstra uma preocupação com as transformações observadas no campo brasileiro, devido à expansão do urbano e da modernização agrícola. Nesse momento, a autora questiona, sobretudo pensando no estudo dos grupos rurais, se a inserção dos elementos urbanos no campo resultaria numa homogeneização rural-urbana. E, com o intuito de embasar a discussão em torno da relação cidade-campo, ressalta que "as relações entre ambos não teriam sido sempre as mesmas” (Queiroz, 1978, p. 47). Então, visando analisar as modificações pelas quais a relação cidade-campo passou, a autora utiliza três configurações maiores de estrutura e organização social: a sociedade tribal, a sociedade agrária e a sociedade urbana. O entendimento da autora é consonante ao que anteriormente foi apresentado, tendo por fundamento as ideias de Marx e Engels. Vale destacar a sua contribuição no que se refere à "sociedade urbana”, considerada também pela autora citada como sociedade industrial, quando se dá, sobretudo, o desenvolvimento tecnológico alcançado na cidade e a sua expansão no campo, pois

[...] a cidade se liberou do meio rural no que toca à produção em geral, e se tornou produtora por excelência, reorganizando o trabalho agrário através das máquinas, impondo ao meio rural seu gênero de vida e sua estratificação social de base econômica; a cidade pode então crescer demograficamente de maneira por assim dizer ilimitada, pois seu abastecimento depende antes de mais nada do desenvolvimento tecnológico (Queiroz, 1978, p. 48).

As ideias expostas até o momento correspondem de fato a uma exposição sucinta de como a divisão do trabalho entre cidade e campo se sucedeu ao longo do tempo, para fundamentar a nossa reflexão e de alguma forma apresentar a compreensão do longo processo histórico. É evidente que abordar a divisão do trabalho é fundamental, pois o desenvolvimento das forças produtivas e a especialização da produção proporcionaram o estabelecimento do campo e da cidade, 
uma vez que, após a divisão da produção entre ambos, fica impossível pensar na existência da cidade sem o campo e vice-versa.

Verificamos, então, a partir da divisão do trabalho, que a cidade e o campo assumiram características próprias, perceptíveis nas formas e nas funções exercidas por cada espaço. A cidade se tornou não apenas o centro político-administrativo, mas também o local da troca e da produção industrial. Em contraposição, o campo especializou-se na produção agrícola. Contudo, também observamos que a relação entre ambos os espaços passou por modificações intensas após o desenvolvimento industrial. O duplo processo, como escreve Lefebvre (2001, 1999 [1970]), de industrialização-urbanização provoca tanto na cidade quanto no campo modificações que são evidenciadas atualmente por meio da flexibilização da divisão do trabalho entre ambos os espaços.

Conhecer a periodização histórica da relação cidade-campo é necessário. Todavia a relação entre a cidade e o campo não ocorreu nem ocorre da mesma forma em todos os espaços-tempo. Os apontamentos aqui destacados relacionados à divisão do trabalho entre cidade e campo retratam características específicas da realidade europeia. Nesse sentido, Queiroz (1978, p. 49) afirma que os três tipos de sociedades (tribal, agrária e urbana) destacados por ela "podem ser concomitantes no tempo e no espaço numa sociedade como a brasileira”. Por isso, cabe aqui discutirmos de que modo a divisão do trabalho e a diferenciação entre cidade e campo aconteceram no Brasil e como os estudiosos preocupados com a relação cidade-campo têm procurado compreender as diversas realidades brasileiras.

\section{A particularidade da relação cidade-campo no contexto brasileiro}

No Brasil, a diferenciação entre cidade e campo não ocorreu da mesma forma que na Europa, já que, no primeiro, tal processo aconteceu lentamente e impulsionado pelo desenvolvimento das forças produtivas e do capitalismo que surgiram na realidade europeia. Na Europa, conforme anteriormente mencionado, o processo de urbanização passou por fases de estruturação que duraram séculos, como a partir da divisão do trabalho entre cidade e campo. No Brasil, ocorreu de modo acelerado, ultrapassando as fases da divisão do trabalho verificadas nos países europeus e apoiando-se, durante muito tempo, nas atividades agrícolas e extrativistas. 
No início da colonização brasileira, quando os portugueses aportaram, encontraram uma "população relativamente pouco numerosa, dispersa, estruturada em grupos de pequeno porte, tecnologia pobre, nômades, e, portanto, desconhecendo cidades" (Queiroz, 1978, p. 279). Eles viviam organizados em sociedades tribais. Nesse momento, a metrópole tinha interesse em extrair as riquezas que pudessem ser encontradas, como metais preciosos, e utilizar as terras a fim de produzir matérias-primas para serem comercializadas e utilizadas para o enriquecimento dos seus impérios. Como bem esclarece Marx, estamos falando do processo de acumulação primitiva do capital.

Nesse contexto, para melhor domínio, fazia-se necessário um lugar onde se pudessem reunir as atividades políticas e administrativas. Para isso, criaram-se algumas cidades localizadas em pontos estratégicos que, conforme Singer (1995), podem ser chamadas de cidades da conquista. Nestor Goulart Reis Filho expõe que, até meados do século XVII, a rede urbana no Brasil diferenciava-se da que se constitui na Europa, uma vez que, no território brasileiro, ela é instalada tendo em vista "exclusivamente o amparo às atividades da agricultura de exportação", compondo parte dos serviços necessários ao funcionamento do sistema (Reis Filho, 1968, p. 184). Em relação a essas primeiras cidades brasileiras, Santos (1993, p. 17) afirma que, "no começo, a 'cidade' era bem mais uma emanação do poder longínquo, uma vontade de marcar presença num país distante”.

Assim, nesse primeiro momento, não existia uma divisão do trabalho entre cidade e campo que fosse baseada em atividades produtivas, já que, na cidade, não havia produção econômica, e a vida socioeconômica se concentrava nas propriedades rurais. Nesse sentido, a população que morava e trabalhava no campo, mais especialmente os proprietários rurais, frequentava a cidade, principalmente em períodos de festividade religiosa ou nos períodos de inverno ou chuvosos. Portanto, "a população de vilas e cidades era quase a mesma da do campo, pois era ela praticamente que ali habitava também” (Queiroz, 1978, p. 280). O autor ainda afirma que a cidade era um prolongamento das fazendas e existia para servi-las.

Do exposto, podemos presumir que não havia uma divisão do trabalho e uma delimitação evidente entre cidade e campo e que a vida entre esses espaços se confundia. Queiroz (1978) também nos chama a atenção para mostrar que a distinção entre cidade e campo não era muito nítida no Brasil e, mesmo atualmente, em alguns municípios, ainda não o é. Esse aspecto, segundo a autora, reflete-se num vício de linguagem que permanece até hoje sendo muito utilizado por nós, 
quando, por exemplo, queremos dizer que vamos ao campo e, geralmente, falamos: "vou para o interior". Logo, embora tendo particularidades, cidade e campo se configuravam como partes de um todo inseparável, em que existia o interior (o campo), disperso, como local dinâmico onde se dava a produção agrícola, e o centro (a cidade), concentrado, como local voltado para a comercialização dos produtos, sobretudo para o mercado externo.

No Brasil, até o século XVIII, a cana-de-açúcar e o ouro eram os produtos mais comercializados para o mercado externo, contudo, posteriormente, no século XIX, houve uma diversificação e passaram a ser exportados outros produtos, como o café, o algodão, o cacau e o fumo ${ }^{44}$. As cidades da conquista eram "um grande arquipélago" (Santos, 1993, p. 26), pois não se relacionavam entre si, e sua economia e produção voltavam-se para atender ao mercado europeu.

Aos poucos, além das cidades da conquista, começaram a surgir outras aglomerações urbanas no interior do país, impulsionadas pelo estabelecimento das fazendas de gado no sertão nordestino. Essa atividade econômica fornecia um excedente alimentar para ser consumido nos engenhos de cana-de-açúcar, nas vilas e nas cidades. Por conseguinte, o processo de ocupação para o interior proporcionou uma divisão espacial do trabalho, em que o litoral se especializou na produção da cana-de-açúcar. Em contrapartida, no Sertão e no Agreste, o complexo algodão-gado-lavouras de subsistência constituiu a base econômica para manter a população brasileira (Andrade, 2007).

Singer (1995 [1973]) explica que o surgimento das fazendas pode ser considerado como o início de um processo de reorganização produtiva porque propiciou a produção de um excedente agrícola comercializável no mercado interno. Considerando que, antes, nas propriedades rurais, havia a produção voltada para o mercado externo e uma pequena produção de alimentos para a subsistência das pessoas que ali viviam e trabalhavam, o comércio nas cidades era restrito às mercadorias exportadas e importadas. Com essa reorganização produtiva, a função comercial da cidade ganha importância, como explica Singer (1995 [1973], p. 102):

4 Vale acrescentar que, muito embora os principais produtos comercializados sejam os citados, houve sim um comércio de exportação de produtos básicos, como farinha e rapadura, provenientes do Brejo paraibano nos séculos XVIII e XIX, como bem analisa Ocione Fernandes (2008). 
[...] o excedente alimentar produzido pela economia de subsistência vai animar agora uma vida comercial cada vez mais ampla, de um lado, pela comercialização do próprio excedente alimentar, e, do outro, devido aos gastos da classe senhorial em todo tipo de bens de luxo, geralmente importados. Esta classe senhorial, composta tanto por plantadores e por mineradores, que produzem para o mercado externo, como por fazendeiros, que produzem para o mercado interno, retém uma parcela ponderável do excedente colonial que é gasta, em sua maior parte, dentro da colônia.

Nesse contexto, as cidades da conquista que só tinham uma função político-administrativa vão se tornando mais dinâmicas e assumindo o caráter de cidade comercial. No entanto, o movimento que se dava nas cidades ainda ocorria, principalmente devido à produção do campo, tanto o movimento financeiro quanto o populacional, pois, na cidade, não se tinha produção econômica considerável, e a maior parte da população vivia do/no campo. Assim, de modo geral, habitavam as cidades administradores civis e militares, religiosos e comerciantes.

Se associarmos o processo de urbanização ao surgimento e ao crescimento de cidades, esse pode ser considerado um fenômeno muito antigo, que acontece desde tempos remotos, muito antes do aparecimento das indústrias. Todavia, se compreendermos a urbanização como atualmente se caracteriza - um processo de expansão das cidades resultante do processo de industrialização -, questiona-se como caracterizar o processo de urbanização. Como explica Lefebvre, esse é um fenômeno mais recente, que iniciou, na Europa, no fim do século XVIII e, no Brasil, no fim do século XIX. Porém, no Brasil e em alguns países onde a industrialização foi tardia, ao contrário do que aconteceu na Europa, podemos afirmar que houve uma diferenciação entre cidade e campo e uma urbanização antes mesmo do aparecimento das primeiras indústrias, pois, anteriormente havia uma verdadeira divisão do trabalho, a partir da produção, os grandes proprietários fundiários que frequentavam a cidade, com o desejo de modernizar-se, tentaram adotar "o modelo de urbanização ocidental" (Maia, 1994, p. 10). Queiroz (1978, p. 57) defende a hipótese de que, 
[...] primeiramente se difundiu no Brasil um gênero de vida ${ }^{55}$, o da sociedade burguesa, a partir de mais ou menos 1820, e antes de entrar o país em verdadeiro processo de industrialização. $\mathrm{O}$ novo gênero de vida diferencia a população urbana não apenas segundo níveis econômicos, porém muito mais ainda culturalmente, sendo que as camadas superiores adotam como sinal distintivo o requinte e um arremedo de cultura intelectual. O que é mais, a partir deste momento - julgamos - vida na cidade e vida no campo também passam a diferenciar-se muito em qualquer nível social.

Com base nas reflexões sobre a urbanização brasileira no século XIX, realizadas por Maia (1994) e Queiroz (1978), verificamos que o modo de vida nas cidades começava a divergir em relação ao modo de vida do campo. Esse fato explicitava-se nos objetos materiais importados e, sobretudo, nos costumes vivenciados na cidade que eram reproduzidos conforme as normas vindas dos países europeus, o que fazia com que o comportamento do indivíduo variasse conforme estivesse no campo ou na cidade (Queiroz, 1978).

No Brasil, o processo de urbanização teve níveis e dinâmicas diferentes, dependendo da localização, do período e, principalmente, das políticas econômicas. Em cidades do interior do território, onde o comércio se mantinha da produção agrícola, e essa produção era voltada para o mercado interno, a população urbana, embora se diferenciasse da população do campo, estava muito próxima dele e ainda conservava algumas práticas e hábitos rurais, sobretudo a população que ficava na periferia e nos arredores das cidades.

Somente entre o final do século XIX e começo do século XX, no Brasil, iniciou-se o processo de industrialização no país, com o objetivo de substituir as importações de produtos vindos do exterior. As primeiras indústrias produziam bens de consumo não duráveis, e sua estrutura e seu maquinário eram muito simples.

5 É importante destacar que preferimos utilizar a noção de modo de vida à de gênero de vida. $\mathrm{O}$ termo genre de vie proposto por La Blache, muito utilizado nos estudos regionais, referia-se ao conjunto de hábitos e técnicas desenvolvidos pelos grupos humanos em determinados lugares ou regiốes e estava relacionado às particularidades culturais existentes em cada grupo, devido às suas relaçóes com outros grupos e com o meio em que habitavam. Segundo Maia (2000), esse termo, ao ser traduzido do francês para o português, recebeu duas denominações. Alguns autores o converteram do sentido literal para o termo "gênero de vida"; outros traduziram para a expressão "modo de vida", levando em consideração o sentido anterior. Assim como essa autora, optamos pelo termo "modo de vida", pois este se refere diretamente a uma maneira ou forma de vida. 
Daí em diante, algumas cidades se tornaram cidades industriais. A partir de então, podemos dizer que, no Brasil, começou uma verdadeira divisão do trabalho entre a cidade e o campo, pois, "no seu intercâmbio com o campo, a cidade pôde finalmente oferecer uma contrapartida econômica em troca do excedente alimentar" (Singer, 1995 [1973], p. 111). O desenvolvimento tecnológico e a intensificação da industrialização no país proporcionaram, inicialmente, a divisão do trabalho entre cidade e campo. No entanto, aos poucos, foram se estruturando outras divisões, como a divisão do trabalho entre as regiões do país que, anteriormente, não se inter-relacionavam, apenas mantinham relações com o exterior. Entretanto, no Brasil, a intensificação do processo de industrialização não foi rápida e só veio provocar modificações no crescimento das cidades, a partir da década de 1930 em diante, como destaca Andrade (2007, p. 217-8), que, ao refletir sobre a economia urbana brasileira, afirma:

O Brasil, que fora até os fins do século passado um país eminentemente agrícola, cujas cidades principais, exercendo funções administrativas e comerciais, tinham um crescimento lento, começou a apresentar, a partir de 1900, com a República, um crescimento urbano mais acelerado. Essa aceleração se acentuaria a partir de 1930 e mais ainda na década 1941-50, a ponto de a sua população urbana ter atingido, nessa época, uma porcentagem superior a $36 \%$ do total.

Entendemos que, no Brasil, antes do processo de industrialização se intensificar, a partir do final do século XIX, algumas cidades mostravam um considerável crescimento populacional e um modo de vida diferenciado em relação ao campo. Contudo, o movimento era lento e acontecia devido ao capital obtido nas atividades primárias e à relação de proximidade com o campo. $\mathrm{O}$ processo de industrialização provocou uma dinamização nas cidades e resultou em uma grande concentração populacional e de serviços. É a partir daí que se propaga, nas cidades brasileiras, a ideia de que a cidade representava o moderno, e o campo, o atrasado.

Com o avanço do processo industrial, o campo também se modernizou. No Brasil, sobretudo a partir das décadas de 1950-60, a incorporação de tecnologias e a modernização no campo redefiniram as relações cidade-campo, e algumas áreas agrícolas foram dominadas por novos aparatos técnicos e por novas lógicas de produção. Santos (1993) destaca que a modernização agrícola aconteceu de maneira generalizada na região concentrada (que abrange alguns 
estados das Regiões Sul, Sudeste e Centro-Oeste). No entanto, no restante do país, ocorreu seletivamente. Desde então, observa-se o que alguns autores, entre eles, Guimarães (1977), denominam de “modernização agrícola conservadora”. Esse termo diz respeito às características da modernização agrícola no Brasil, que ocorreu associando a entrada de inovações tecnológicas no campo à manutenção e à ampliação da concentração e da especulação fundiária pelos grandes proprietários rurais.

Tais circunstâncias provocaram a expulsão de pequenos agricultores do campo, forçando-os a migrarem para as cidades, pois a maioria não tinha condições de competir com os grandes produtores e manter sua produção. Assim, esses pequenos agricultores, em grande parte, não proprietários, tiveram como saída procurar na cidade melhorias de vida, onde se alocavam nas mais diversas condições. Muitos mantiveram práticas originárias do campo, por "necessidade" ou por "desejo" (Maia, 1994).

Pelo exposto, verificamos que, no Brasil, o campo sempre esteve muito próximo da cidade. $\mathrm{E}$, embora reconheçamos a existência de fatores responsáveis pela difusão do urbano no campo, como a intensificação da modernização e a reestruturação produtiva, não podemos esquecer a permanência do modo de vida rural que, ainda que se altere com o crescimento urbano, permanece não só no campo, mas também na cidade.

A divisão do trabalho entre cidade e campo, atualmente, é cada vez mais complexa devido a diversos fatores, a saber: a expansão do urbano e a reestruturação produtiva; atividades urbanas, no campo, e rurais, na cidade; além das atividades econômicas que mesclam o urbano e o rural. No campo, temos visto o aparecimento de atividades que reproduzem práticas tipicamente rurais a partir da lógica urbana. É o caso do turismo rural, em que se emprega um modo de vida rural como estratégia de mercado. Outra atividade é a ampliação do mercado imobiliário, em que se utiliza o campo para a construção de condomínios rurais para segundas residências.

Ainda que a expansão do urbano, ao longo do campo, seja uma realidade incontestável, isso não ocorre sempre de modo contínuo, pois, em meio a esse contínuo urbano, persistem descontinuidades rurais. Assim, considerando-se a realidade brasileira, como refere Maia (1994), as ruralidades não são encontradas somente no campo, mas também nas cidades. Partindo dessa compreensão, apresentaremos as noções basilares para esta discussão: cidade, campo, urbano e rural. Nosso intuito é trazer algumas opiniões sobre a relação entre cidade 
e campo e entender o fundamento do que delas derivam: o urbano e o rural, pensando, sobretudo, na realidade brasileira.

\section{Cidade, campo, urbano e rural: perspectivas e análises}

O desenvolvimento das forças produtivas e a divisão do trabalho determinaram uma organização social e econômica entre cidade e campo, especificando o campo como responsável pela produção agrícola, e a cidade, pela produção industrial, pelo comércio e pelos serviços. Entretanto, atualmente, temos vivenciado uma reestruturação produtiva, cujas atividades econômicas originalmente encontradas nas cidades têm se fixado no campo. Nesse sentido, a relação cidade-campo está despertando cada vez mais a atenção de pesquisadores de diversas áreas do conhecimento, como sociólogos, geógrafos, economistas, antropólogos, etc., cujas pesquisas têm demonstrado a necessidade de se compreenderem as mudanças provocadas com as novas relações estabelecidas entre a cidade e o campo.

Temos identificado que a maioria dos trabalhos acerca da relação cidade-campo trata da expansão do urbano sobre o campo, em que os autores buscam identificar os novos objetos e entender como se dão as novas relações entre esses espaços. É comum encontrarmos discussões embasadas em conceitos e noções, tais como: novo rural, novas ruralidades, pluriatividade, continuum rural-urbano, urbanidades no rural, espaço periurbano, entre outras denominações.

Nessa perspectiva, a fim de fundamentar nossa discussão, procederemos a um debate sobre os pares conceituais cidade/campo e urbano/rural, apontando como tais conceitos foram modificados devido à intensificação do processo de urbanização. E abordaremos as principais perspectivas que vêm sendo construídas sobre a relação cidade-campo, no contexto atual brasileiro.

Anteriormente à segunda metade do século XX, os interessados em entender a cidade e o campo fundamentavam suas pesquisas nas diferenças encontradas entre esses espaços, pois eles eram considerados espaços contraditórios que apresentavam realidades muito distintas. Logo, não havia uma preocupação com a relação que havia entre ambos os espaços - cidade e campo -, a análise era feita baseada na concepção dicotômica e os estudos realizados de modo sistemático e comparativo.

Marx (2007 [1932]) expõe que a "cidade já é obra da concentração da população, dos instrumentos de produção, do capital, do desfrute e das necessidades, ao passo que o campo representa o expoente cabal ao fato contrário, 
quer dizer ao isolamento e à solidão”. Nessa assertiva, podemos perceber uma descrição característica de uma análise dicotômica, pois as características de cada espaço são apresentadas com um enfoque nos aspectos opostos - concentração e isolamento - de cada um. É importante frisar que o período vivenciado por Marx - século XIX - foi uma fase de grande efervescência industrial na Europa, onde os contrastes entre a vida urbana e a rural se intensificaram.

No início do século XX, uma das áreas do conhecimento que demonstrou bastante interesse em analisar as particularidades da cidade e do campo foi a Sociologia. As pesquisas nessa área apontavam critérios diferenciados fundamentais para se comparar a sociedade urbana com a rural. Os principais critérios destacados por Solari (1979) e que eram utilizados nesse período eram: a ocupação dos indivíduos (atividade econômica), o contato com a natureza, a densidade populacional, a diferenciação social, a mobilidade, a estratificação e a interação social, as relações diretas e indiretas e a relação com a vizinhança. Além disso, a cidade e o campo eram compreendidos com base em seu oposto e definidos levando em consideração o outro. Também não havia uma diferença entre forma e conteúdo, ou seja, a cidade e o urbano eram definidos como uma única coisa, assim como o campo e o rural. Por conseguinte, a organização espacial e o modo de vida eram compreendidos a partir de um mesmo conceito.

Tal fato é evidente quando resgatamos as ideias de Park (1973), que atribui ao conceito de cidade aspectos materiais e sociais. Assim, a cidade é composta por instalações necessárias às atividades citadinas, estruturas administrativas e políticas, serviços, mas também por um conjunto de costumes e tradições. Park (1973, p. 28, grifos nossos) afirma que

A cidade é algo mais do que um amontoado de homens individuais e de conveniências sociais, ruas, edifícios, luz elétrica, linhas de bonde, telefones etc.; algo mais também do que uma mera constelação de instituições e dispositivos administrativos - tribunais, hospitais, escolas, polícia e funcionários civis de vários tipos. Antes, a cidade é um estado de espírito, um corpo de costumes e tradições e dos sentimentos e atitudes organizados, inerentes a esses costumes e transmitidos por essa tradição. Em outras palavras, a cidade não é meramente um mecanismo físico e uma construção artificial. Está envolvida nos processos vitais das pessoas que a compõem; é um produto da natureza, e particularmente da natureza humana. 
Na primeira metade do século XX, Wirth (1973), destacando o urbanismo como um modo de vida, coloca à frente dos estudiosos da época e estabelece uma diferença entre os conceitos de cidade e de urbano ao afirmar que as cidades se limitam à estrutura física, enquanto o urbano pode se espalhar em direção a comunidades rurais, o que possibilita que o modo de vida urbano penetre o campo. Do mesmo modo que Solari (1979) destacou as relações sociais como um critério para diferenciar a sociedade rural da urbana, Wirth (1973) evidenciou, como característica do modo de vida urbano, a substituição dos contatos primários (diretos) pelos secundários e o enfraquecimento dos laços familiares e da relação com a vizinhança.

A diferenciação proposta por Wirth (1973) entre cidade e urbano fica mais evidente a partir da segunda metade do século XX, quando ocorrem mudanças no campo provocadas pela industrialização e pela entrada de equipamentos e de hábitos urbanos. Daí em diante, os autores passaram a identificar urbano e rural como modos de viver e de apropriar o espaço. Em contrapartida, cidade e campo se restringiram a realidades espaciais, que tendem cada vez mais a se relacionar de maneiras distintas produzindo uma realidade complexa.

Da segunda metade do século XX em diante, o interesse em estudar a relação cidade-campo põe-se em evidência. Essa relação passa a ser compreendida por alguns por meio da expressão continuum rural-urbano. Um dos primeiros a sistematizar a noção desse vocábulo foi o antropólogo Redfield, que propôs a existência de um continuum entre o campo e a cidade, com o intuito de ressaltar as permanências e as transformações sofridas pelas comunidades rurais a partir da influência do modo de vida urbano.

O termo continuum rural-urbano vem sendo utilizado, mais recentemente, a partir de várias vertentes. Podemos distinguir três vieses de análise, pois alguns o utilizam para dar ênfase à inevitável urbanização do campo; outros, para explicar o aparecimento de áreas que mesclam aspectos rurais e urbanos; e há os que, apesar de admitirem a existência de um movimento contínuo de expansão do urbano, destacam a permanência do rural tradicional e sua reconstrução.

No primeiro enfoque, observamos uma forte relação do continuum rural-urbano com a expansão do urbano sobre o campo. Essa concepção baseia-se na ideia de que ocorrerá uma total "urbanização do campo", por isso ele perderá as características relacionadas ao rural tradicional e surgirá uma realidade com novos elementos e novas relações provenientes da junção do urbano com o rural, formando, então, o espaço rurbano. O termo "rurbano" é utilizado para dar ênfase 
à superação entre os dois espaços, onde desaparecem tanto a vida urbana quanto a rural, ou seja, tem-se uma fusão entre os dois espaços e os dois modos de vida. Trazemos aqui uma síntese de alguns grupos de pesquisa e de estudos realizados no Brasil que vêm se dedicando à análise das relações cidade e campo. Longe de mostrarmos o conjunto das produções sobre a temática, o nosso intuito é oferecer ao leitor algumas vertentes teórico-metodológicas sobre a temática. Iniciemos pelo grupo coordenado por Graziano da Silva. Este vem desenvolvendo o Projeto Rurbano, que tem como objetivo analisar as principais transformações ocorridas nas últimas décadas no espaço rural brasileiro. Utilizando-se de dados da Pesquisa Nacional por Amostra de Domicílios (PNAD), os estudos coordenados pelo referido professor pretendem mostrar o crescimento do que denominam de "novo rural brasileiro". O grupo tem verificado, no espaço rural brasileiro, principalmente no Centro-Sul, mudanças como o aumento de atividades não agrícolas e de pessoas do campo envolvidas nessas atividades e no rendimento dessa população (Silva et al., 2002).

Conforme Silva (1997), o "novo rural brasileiro" é um continuum urbano, que se modifica e se encontra cada vez mais urbanizado, devido a dois fatores: ao "processo de industrialização da agricultura" e ao "transbordamento do mundo urbano naquele espaço que, tradicionalmente, era definido como rural". Graziano da Silva (1997) assevera que o "novo rural" compõe-se basicamente de três grupos de atividades: a) a agropecuária moderna diretamente ligada às agroindústrias; b) as atividades não agrícolas relacionadas à moradia, ao lazer, às atividades industriais e à prestação de serviços; e c) as "novas" atividades agropecuárias, que são as atividades tradicionais do campo que estão sendo revalorizadas pelo mercado capitalista.

$\mathrm{Na}$ segunda vertente sobre o continuum rural-urbano, verificamos a utilização desse termo para explicar o surgimento de espaços intermediários entre a cidade e o campo, os quais, apesar de ainda não estarem localizados na área urbana, são muito influenciados pelas atividades advindas dela. Nessa perspectiva, os autores consideram que, embora permaneçam características tradicionais rurais no campo, a expansão da malha urbana tem adentrado esse espaço, provocando mudanças socioeconômicas e espaciais. Portanto, ressaltam que o processo de urbanização tem proporcionado o crescimento de atividades não agrícolas associadas às atividades agrícolas, e isso contribui para a formação de áreas complexas de transição rural-urbana, que, apesar de manterem paisagens rurais, mesclam, cada vez mais, as lógicas rural e urbana. 
Assim, há grupos de estudiosos que procuram entender o "espaço periurbano", geralmente, utilizando as ideias expostas sobre o continuum rural-urbano. Nesse sentido, destacamos as reflexões que vêm sendo construídas por Vale (2005), que refere que, entre o campo e a cidade, existe um continuum espacial que, ao mesmo tempo, interliga e distingue essas duas realidades. Tal área de transição evidencia uma grande interdependência e complementaridade entre esses espaços, por isso é difícil diferenciar o que seria uma paisagem rural ou urbana. A essa área a autora denomina de espaço periurbano.

A outra vertente trata o continuum rural-urbano como um processo constante de expansão do urbano sobre o campo, que, apesar de provocar mudanças nas relações cidade-campo e proporcionar o surgimento de novas áreas de transição e novos conteúdos, não elimina os conteúdos originais de cada espaço. Nesse sentido, a existência do continuum urbano sobre o campo não provoca uma homogeneização dos espaços, mas uma sobreposição de usos e de práticas espaciais diferenciadas e contraditórias. Poderíamos relacionar vários autores a essa vertente, no entanto a maior parte deles não utiliza a expressão continuum rural-urbano para fundamentar suas ideias, ao contrário, criticam-na, afirmando que ela representa a inexorável urbanização do campo e o desaparecimento do modo de vida rural tradicional.

Rosa e Ferreira (2006), todavia, apesar de destacarem as novas relações entre cidade e campo, demonstram uma preocupação acerca da necessidade de estudos que discutam o modo de vida rural e a própria ruralidade, confirmando que, no Brasil, em meio aos processos de transformação, tanto no campo quanto na cidade, existe uma ruralidade em reconstrução interligada ao urbano que carece de análises. Assim, as autoras propõem que se deva pensar no uso da definição de continuum, desde que não seja baseado nas ideias relacionadas à dicotomia e à visão voltada para a abrangência total do urbano em contraposição ao rural. Então, consideram que

[...] campo e cidade só podem ser concebidos - na contemporaneidade - em suas relações. [...] E nesse contexto, acredita-se que o conceito de continuum possa ser repensado, não para reforçar a dicotomia urbano-moderno versus rural-atrasado, mas para salientar a perspectiva de que tanto o campo, quanto a cidade - e tanto a população rural, quanto a população urbana - são partes de uma mesma sociedade (Rosa e Ferreira, 2006, p. 196). 
Como vimos, a ideia de continuum rural-urbano pode denotar vários direcionamentos. Aqui, tentamos agrupar em três vertentes principais para facilitar a compreensão. Ressaltamos que, atualmente, podemos encontrar, de maneira clara ou subentendida, cada uma dessas vertentes. A expressão continuum geralmente não é utilizada como foco principal nas pesquisas, contudo a forma como é exposta no texto, associada a outros termos e conceitos, auxilia a entender o posicionamento do autor acerca da relação cidade-campo. Logo, para visualizar como tem sido estudada a relação cidade-campo, sobretudo no Brasil, é necessário destacarmos algumas pesquisas realizadas recentemente e os principais conceitos básicos utilizados.

Existem alguns estudiosos e grupos de pesquisa preocupados em compreender as mudanças que vêm ocorrendo nas relações entre cidade/campo e urbano/ rural. Tais preocupações já resultaram em frutos como artigos, dissertações e teses sobre o tema. Essa realidade se diferencia bastante de duas décadas atrás, período em que ainda não havia tantos trabalhos e projetos interessados nessa discussão. Entre esses grupos de pesquisa, destacamos o Núcleo de Estudos de Geografia Fluminense (NEGEF), coordenado pelos professores Glaucio Marafon e Rogério dos Santos Seabra, na Universidade do Estado do Rio de Janeiro, que desenvolvem pesquisas e orientam trabalhos que têm como objetivo compreender as mudanças espaciais, sociais e políticas causadas pela crescente urbanização, no interior fluminense, e verificar as estratégias da produção familiar para sobreviver, seja por meio de empregos agrícolas ou não agrícolas, bem como entender o papel que o turismo rural vem desempenhando nesse processo.

Assim, os pesquisadores citados debatem sobre as mudanças provocadas principalmente pela intensificação da urbanização e pelo estabelecimento de novas atividades no campo, sobretudo em municípios do interior do estado do Rio de Janeiro. Para tanto, estruturam as discussões a partir da necessidade de se repensar o rural (a ressignificação do rural) e, a fim de explicar as novas atividades encontradas no campo, utilizam noções e conceitos, como: urbanidades, ruralidades, novas ruralidades, urbanidades no rural e pluriatividade.

Biazzo (2009), Fusco (2005), Marafon (2014), Silva (2008) e Rua (2003) compreendem que o rural, no Rio de Janeiro, já não pode ser associado apenas às atividades agrícolas e que é preciso repensar a existência das atividades não agrícolas no campo. Em relação ao processo de urbanização, entendem que a lógica urbana avança e chega ao campo, no entanto esse processo não causa o fim do 
rural, mas proporciona, devido às inter-relações entre urbanidades e ruralidades, o aparecimento de novas ruralidades.

Para explicar a dinamicidade entre as atividades urbanas e as rurais, os autores citados preferem utilizar os termos urbanidades e ruralidades, em vez de urbano e rural, pois urbanidades-ruralidades estão relacionadas a lógicas, a racionalidades e a aspectos culturais (e não, apenas, econômicos), que se territorializam, ao contrário dos termos urbano e rural, que, apesar de se referirem a lógicas e a modos de vida específicos, geralmente estão relacionados a um recorte espacial e, às vezes, precisam desse recorte espacial para ser bem mais compreendidos. Biazzo (2009, p. 79) refere que "o uso das expressões ruralidades e urbanidades parece mais adequado do que 'rural' e 'urbano', pois expressam maior dinamismo através de identidades sociais que constantemente se reconstroem”.

Rua (2003) afirma que rural e urbano se integram, mas sem se tornarem a mesma coisa, pois preservam suas especificidades. Para chegar a essa assertiva, o autor baseia-se tanto em estudos que centram a análise no urbano quanto em obras que dão ênfase às especificidades do rural. Logo, enfatiza o processo de urbanização da sociedade e, ao mesmo tempo, a permanência do rural, que, segundo ele, se dá, entre outros modos, pela reapropriação de elementos da cultura rural pelo urbano. Assim, propõe o uso das expressões "urbanidades no rural" e "novas ruralidades" simultaneamente, pois, desse modo, é possível ter uma dimensão dos processos que caracterizam as relações entre cidade e campo sem perder de vista a ideia do todo. Para esse autor, "desenham-se múltiplas espacialidades/territorialidades (híbridas de urbano e rural, numa integração multiescalar), que marcam o momento atual de (re)significação do rural e da natureza" (Rua, 2003, p. 54).

O fenômeno da pluriatividade, definido por Silva (1997), a partir da perspectiva econômica, como a "combinação de atividades agrícolas e não agrícolas", vem sendo observado e estudado no interior do Rio de Janeiro pelos integrantes do NEGEF, que têm procurado desvendar essa noção, destacando-a como uma possibilidade de resistência das famílias para permanecerem no campo diante da expansão do urbano e contrapondo-se, portanto, à associação dessa noção somente à expansão de atividades não agrícolas nos espaços rurais. Silva (2008) destaca o caráter heterogêneo e diversificado desse fenômeno ao compreendê-lo como o entrelaçamento da expansão da modernização e da lógica urbana sobre o campo com as estratégias sociais e produtivas de permanência das famílias. Tal perspectiva se reafirma nas pesquisas realizadas por Marafon (2014) ao estudar 
o território fluminense e mostrar que cada vez mais, no campo, há atividades não agrícolas, a exemplo da produção industrial e de atividades voltadas para o turismo.

Com base no exposto, entendemos que os integrantes do NEGEF ressaltam, na análise acerca da relação cidade-campo, a sobreposição e a inter-relação entre as lógicas urbana e rural. Utilizando como objeto de estudo municípios ou regiões do interior fluminense, procuram dar ênfase à expansão do urbano sobre o campo e observam tanto as mudanças quanto as permanências. Os termos urbanidades, ruralidades, novas ruralidades e urbanidades no rural são utilizados simultaneamente, visando a dar conta da realidade, que é compreendida como um espaço híbrido composto por várias territorialidades, que são constituídas a partir das lógicas urbana e rural.

No Rio Grande do Sul, alguns professores e estudantes também vêm demostrando interesse pela temática "relação cidade-campo", e, assim como no Rio de Janeiro, os trabalhos destacam as mudanças ocasionadas pela expansão da lógica urbana sobre o campo. No entanto, a dissertação de Kozenieski (2010), orientada por Medeiros, apesar de reconhecer o aparecimento de atividades não agrícolas no município (como haras, sítios de segunda residência, estabelecimentos de lazer rural etc.), teve como objetivo analisar a permanência de atividades caracteristicamente agrícolas no município de Porto Alegre.

Kozenieski (2010), para explicar a existência de atividades agrícolas diante da expansão do urbano, utilizou o conceito de território e a noção de territorialidade. Percebemos que as reflexões desse autor são bastante similares às que estão sendo realizadas pelo NEGEF. É possível verificar tal posicionamento quando ele afirma: "A urbanização se faz presente na escala local como a presença de urbanidades no rural. A presença dessas urbanidades não significa necessariamente a extinção do rural, podem representar um espaço híbrido, de convívio desses dois modos de vida, com a conformação de espaços híbridos” e que "a presença de urbanidades não significa o fim do rural, pode representar o convívio dessas suas espacialidades" (Kozenieski, 2010, p. 39).

Como podemos observar, esse autor utilizou os mesmos termos analisados por Rua (2003): “urbanidades no rural” e "espaço híbrido”. As análises acerca da relação cidade-campo são bem semelhantes, contudo, ao invés de destacar as urbanidades no rural, Kozenieski teve como propósito destacar as atividades rurais presentes na área rural do município de Porto Alegre, verificando duas territorialidades: uma expressa por meio da identidade dos produtores com o 
lugar e com as atividades agrícolas, marcada pelo prazer e por se manter mesmo diante da especulação imobiliária; e a outra, caracterizada pela estagnação e por ser mantida por agricultores com idades elevadas, que não querem mudar de profissão nem buscar alternativas.

Observamos aqui interpretações sobre a relação cidade-campo que procuram entendê-la na perspectiva da existência e da construção de multiterritorialidades (urbanidades e ruralidades) entre esses dois espaços. Tal concepção foi encontrada entre estudiosos que desenvolvem pesquisas no Rio de Janeiro e no Rio Grande do Sul. Conforme suas pesquisas, é necessário repensar a cidade e o campo, pois as relações intensas entre eles têm proporcionado a construção de novas urbanidades e de ruralidades, que são territorialidades sobrepostas num espaço híbrido, onde é difícil definir o que é rural e o que é urbano.

Existem alguns trabalhos desenvolvidos por estudiosos em municípios do interior paulista que, embora não se contraponham a essas reflexões, têm dado destaque aos conceitos de urbanização difusa ou dispersa e espaço periurbano. Estes têm sido utilizados para analisar a relação cidade-campo em municípios onde a urbanização se caracteriza pelo processo de desconcentração espacial, que provoca o crescimento das cidades de maneira espraiada, proporcionando, por conseguinte, o estabelecimento de atividades urbanas em áreas rurais distantes das cidades.

Apesar dos conceitos "urbanização dispersa ou difusa” e "espaço periurbano" ainda serem definições pouco utilizadas no Brasil, alguns pesquisadores, como Sposito (2011) e Reis (2006), têm procurado difundi-las e utilizá-las, analisando algumas cidades e municípios particularmente do Sudeste brasileiro. Nesse sentido, encontramos dois trabalhos que discutem a relação cidade-campo e que recorrem a esses dois conceitos: um deles é uma dissertação desenvolvida por Noronha (2008), cujo objeto de estudo foi o município de Jundiaí-SP; o outro é uma tese realizada por Vale (2005), escrita com o objetivo de definir e compreender o conceito de espaço periurbano como uma categoria de análise geográfica. Esta última autora buscou entender a dinâmica e as características do espaço periurbano no município de Araraquara-SP.

A urbanização difusa ou dispersa caracteriza-se pela expansão não apenas da lógica urbana, mas também da malha urbana de maneira intensa, ou seja, a cidade difunde-se para além dos limites administrativos. É nesse sentido que Dematteis (1998) relacionou, de modo metafórico, essa urbanização a uma mancha de azeite. Essa desconcentração urbana está associada a vários fatores, 
como a expansão dos meios de comunicação, a mecanização agrícola e a difusão industrial e de serviços, além da busca da população citadina pela moradia e pelo lazer em áreas rurais não tão distantes das cidades.

Vale (2005, p. 17) e Noronha (2008, p. 117) consideram o espaço periurbano como resultado do processo de desconcentração urbana. Para ambos os autores, o espaço periurbano é uma área de transição rural-urbana onde se verifica uma crescente complexidade e interdependência entre a cidade e o campo. Assim, tanto a urbanização difusa quanto o espaço periurbano estão relacionados à expansão das malhas urbanas e ao surgimento de novos conteúdos em áreas rurais, consideradas áreas de transição rural-urbana.

Sob o ponto de vista de Vale (2005), a característica marcante do espaço periurbano é a plurifuncionalidade. Ela enuncia que, embora a mistura de usos do solo não seja uma característica exclusiva desse espaço, já que são comuns as práticas agrícolas em áreas urbanas e a implantação de indústrias em áreas rurais, "no espaço periurbano, essa mistura pode ser tão intensa, que dificulta a separação entre o que é rural (ou agrícola) do que é urbano. Isso permite que a dinâmica periurbana tenha características próprias" (p. 81-2). Pablo Gutman et al. (1987, p. 17), analisando o espaço periurbano da Grande Buenos Aires, também salientam que "es un área de competencia de numerosos usos, y por ello mismo de conflitos potenciales. Notoriamente el uso rural es el más débil, el que cede espacio frente al avance de las otras atividades".

A partir do exposto, verificamos que se tem discutido muito sobre a intensificação e a expansão da urbanização sobre o campo. Os debates a respeito do fenômeno urbano e a relação cidade-campo geralmente baseiam-se em abordagens centradas nos novos conteúdos e nas novas relações que vêm surgindo entre a cidade e o campo. Contudo, isso não significa dizer que as reflexões expostas até aqui não reconheçam a permanência do rural tradicional, mas queremos destacar que a maioria das pesquisas utiliza como objeto de análise o aparecimento das novas ruralidades, como, por exemplo, as agroindústrias, as segundas residências, o turismo rural, a pluriatividade etc., provocado pela expansão do modo de vida e dos equipamentos urbanos sobre o campo.

Uma outra perspectiva de análise da relação cidade-campo é desenvolvida pelo Grupo de Pesquisa Globalização, Agricultura e Urbanização (Globau), da Universidade Estadual do Ceará, liderado pelos professores Denise Elias e Renato Pequeno, e pela Rede de Pesquisas sobre Regiões Agrícolas, coordenado por Eve-Anne Buhler, da Universidade Federal do Rio de Janeiro. Ambos os 
grupos reúnem pesquisadores que desenvolvem estudos sobre a transformação da produção no campo, particularmente a partir da reestruturação dos processos produtivos e das relações sociais de produção e as suas repercussões nos circuitos espaciais e na conformação do que denominam de regiões do agronegócio globalizado. A produção acadêmica dos pesquisadores é intensa e muito vem contribuindo para desvendar as mudanças nos arranjos produtivos no território brasileiro e que incidem no pensar as relações cidade e campo, rural e urbano.

Elias (2018) expõe, na introdução da obra Tendências da urbanização brasileira: novas dinâmicas e estruturação urbano-regional, como principais vetores da remodelação do território brasileiro: "a descentralização industrial; a difusão do agronegócio; a guerra dos lugares pelos investimentos produtivos; as especializações produtivas do território, entre outros” (p. 9). Destaca-se aqui a discussão efetivada por Elias e Pequeno (2018) a respeito da (re)estruturação urbano-regional e da cidade. A partir dos estudos realizados na cidade de Mossoró, no Rio Grande do Norte, os autores desvelam os arranjos produtivos na região "comandada" pela respectiva cidade, bem como as "interseções derivadas de associações entre os diferentes agentes produtores do espaço urbano” (ELIAS, 2018, p. 13).

Em publicação na revista da Associação Nacional de Pós-Graduação em Geografia (Revista da Anpege), Castillo et al. (2016) discutem as relações cidade e campo e a reestruturação urbana. Os autores entendem que a

sociabilidade urbana estende-se ao campo modernizado que, por sua vez, demanda funções urbanas que respondam ao consumo produtivo da agropecuária intensiva, tais como comércio e serviços especializados, armazenamento e processamento de matérias-primas agrícolas, finanças, logísticas, administração e contabilidade agrícolas, assistência técnica, dentre outros (p. 268).

Eles acrescentam que, dada a complexidade das interações espaciais, as relações campo-cidade se transformam, especialmente as pequenas e médias cidades, evidenciando-se as cidades funcionais ao campo moderno. Por conseguinte, acirram-se as desigualdades sociais e as contradições de classe.

Observa-se que há uma preocupação por parte dos pesquisadores, especialmente no campo da geografia, em entender as transformações e as novas conformações e reestruturações das relações cidade e campo, seja do ponto de vista das relações de produção, das relações territoriais e interespaciais e regionais e mais propriamente dos pares que se apresentavam como antagônicos, como 
cidade e campo. Pois, de fato, não se pode mais compreender as relações cidade e campo a partir da clássica divisão territorial do trabalho. As relações sociais de produção se transformaram, os arranjos produtivos foram e continuam sendo reconfigurados, bem como o próprio processo de urbanização se torna mais complexo. Há, portanto, algumas questões que carecem de novas reflexões: como entender os espaços periurbanos, considerando os processos de dispersão urbana? Ao tempo em que se dão as transformações das cidades em razão da modernização do campo e que acirram as desigualdades sociais, como se dão as repercussões de tais processos nas cidades externas às denominadas regióes do agronegócio? De que maneira os novos assentamentos agrários, a luta dos movimentos rurais, repercutem nas relações campo e cidade e rural e urbano?

Mesmo considerando as diversidades do território brasileiro, fato é que há um acirramento das desigualdades socioespaciais e os espaços antagônicos persistem quiçá de forma latente: grandes condomínios residenciais verticais e horizontais ao lado de áreas ainda rurais com criação pecuária e que normalmente funcionam como áreas de pousio ou de especulação imobiliária; novas empresas agrícolas onde trabalham habitantes das cidades; feiras agroecológicas com produtos provenientes dos assentamentos agrários e grandes estabelecimentos comerciais que também oferecem produtos orgânicos; movimentos de luta por moradia e movimentos de luta por terra; produções agropecuárias que utilizam tecnologia de ponta e pequenas produções de alimentos e de animais para consumo familiar em quintais ou em áreas de ocupação precária nas cidades.

\section{Considerações finais}

Com base no exposto, compreendemos que há uma lógica dominante expressa na expansão da urbanização sobre o campo. Contudo, reconhecemos que, embora haja um inevitável continuum da cidade sobre o campo, tal fenômeno não provoca uma total homogeneização dos espaços, pois a produção do urbano implica a sobreposição de usos e de práticas espaciais diferenciadas e contraditórias, mas que se complementam. Em outras palavras, apesar do processo avassalador com a tendência a transformar o mundo "homogêneo", não há uma extinção por completo das diversidades. Mesmo fragmentadas, persistem diferenças e resistências, enfim os resíduos. Isto é, as sobrevivências de tempos e de espaços que muitas vezes sobrevivem no todo ou em parte. 


\section{Referências}

ABREU, Mauricio. "Construindo uma geografia do passado: Rio de Janeiro, cidade portuária, século XVIII”. Revista GeoUsp, n. 7, p. 13-25, 2000.

ANDRADE, Manuel Correia de. Formação territorial e econômica do Brasil. Recife: Fundação Joaquim Nabuco, Editora Massangana, 2007.

BIAZZO, Pedro Paulo. Relações campo-cidade na região norte-fluminense: ruralidades e urbanidades em transformação (dissertação). Universidade do Estado do Rio de Janeiro, 2009.

CASTILLO, Ricardo et al. "Regiões do agronegócio, novas relações campo-cidade e reestruturação urbana”. Revista da Anpege, Associação Nacional e de Pós-Graduação e Pesquisa em Geografia, v. 12, n. 18, p. 265-88, 2016.

DEMATTEIS, Giuseppe. "Suburbanización y periurbanización, ciudades anglosajonas y ciudades latinas". In MONCLUS, F. J. La ciudad dispersa: suburbanización y nuevas periferias. Barcelona: CCCB, 1998.

ELIAS, Denise. "A pesquisa, os mecanismos de interação e a coletânea". In e PEQUENO, Renato. Tendências da urbanização brasileira: novas dinâmicas de estruturação urbano-regional. Rio de Janeiro: Letra Capital, 2018, p. 9-24.

e PEQUENO, Renato. Tendências da urbanização brasileira: novas dinâmicas de estruturação urbano-regional. Rio de Janeiro: Letra Capital, 2018.

FERNANDES, Ocione do Nascimento. A produção e a comercialização de mercadorias no Brejo da Parahyba do Norte (1793-1883) (dissertação). Universidade Federal da Paraíba, 2008.

FUSCO, Fabrício Marini. Entre campos e cidades: uma buscapelas multiterritorialidades fluminense (dissertação). Universidade do Estado do Rio de Janeiro, 2005.

GUTMAN, Pablo et al. El campo em la ciudad: la producción agrícola em la Gran Buenos Aires. Buenos Aires: Ediciones CEUR, 1987.

KOZENIESKI, Éverton de Moraes. O rural agrícola na metrópole: o caso de Porto Alegre/ $R S$. (dissertação). Universidade Federal do Rio Grande do Sul, 2010.

LEFEBVRE, Henri. "Notas sobre a Cidade Nova". Introdução à modernidade. Rio de Janeiro: Paz e Terra, 1969, p. 137-47.

. Lógica formal/lógica dialética. Rio de Janeiro: Civilização Brasileira, 1991.

. Revolução urbana. Belo Horizonte: Ed. UFMG, 1999 a. . A cidade do capital. Rio de Janeiro: DP\&A, $1999 \mathrm{~b}$.

. O direito à cidade. 4. ed. São Paulo: Centauro, 2001.

LE GOFF, Jacques. O apogeu da cidade medieval. Trad Antônio de Padua Danesi. São Paulo: Martins Fontes, 1992.

MARAFON, Glaucio José. “Territorialidades, ruralidades e as relações campo-cidade”. Campo-Território, Revista de Geografia Agrária, edição especial do XXI ENGA-2012, p. 1-13, jun. 2014. 
MAIA, Doralice Sátyro. O campo na cidade: necessidade e desejo (um estudo sobre subespaços rurais em João Pessoa-PB) (dissertação). Universidade Federal de Santa Catarina, 1994.

MARX, Karl e ENGELS, Friedrich. A ideologia alemã. São Paulo: Moraes, 1984. $\mathrm{e}$ - A ideologia alemã: critica da novissima filosofia alemã em seus representantes Feuerbach, B. Bauer e Stirner, e do socialismo alemã em seus diferentes profetas (1845-1846). Rio de Janeiro: Civilização Brasileira, 2007.

MERRIGTON, John. "A cidade e o campo na transição para o capitalismo". In HILTON, Rodney. A transição do feudalismo para o capitalismo. São Paulo: Paz e Terra, 1977. NORONHA, Elias Oliveira. O espaço rural no contexto da urbanização difusa: o estudo da pluriatividade nos Bairros Rurais Roseira e Toca no municipio de Jundiai-SP (dissertação). Universidade Estadual Paulista, 2008.

PARK, Robert Ezra. "A cidade: sugestões para a investigação do comportamento humano no meio urbano". In VELHO, Otávio Guilherme. O fenômeno urbano. 2. ed. Rio de Janeiro: Zahar Editores, 1973, p. 25-66.

QUEIROZ, Maria Isaura Pereira de. Cultura, sociedade rural, sociedade urbana no Brasil. Rio de Janeiro: Livros Técnicos e Científicos; São Paulo: Ed. Universidade de São Paulo, 1978.

REIS FILHO, Nestor Goulart. Contribuição ao estudo da evolução urbana do Brasil. São Paulo: Livraria Pioneira Editora/Editora da Universidade de São Paulo, 1968. . Notas sobre urbanização dispersa e novas formas de tecido urbano. São Paulo: Via das Artes, 2006.

ROSA, Lucelina Rosseti e FERREIRA, Darlene Aparecida de Oliveira. "As categorias rural, urbano, campo, cidade: a perspectiva de um continuum". In SPOSITO, Maria Encarnação Beltrão e WHITACKER, Arthur Magon (orgs.). Cidade e campo: relações e contradições entre urbano e rural. 1. ed. São Paulo: Expressão Popular, 2006, p. $187-204$

RUA, João. "A resignificação do rural e as relações cidade-campo: uma contribuição geográfica”. Revista da ANPEGE, ano 1, n. 1, p. 45-66, 2003.

SANTOS, Milton. A urbanização brasileira. São Paulo: HUCITEC, 1993.

SILVA, José Francisco Graziano da. "O novo rural brasileiro". Revista Nova Economia, v. 7, n. 1, p. 1-28, maio 1997.

et al. "O que há de realmente novo no rural brasileiro". Cadernos de Ciência e Tecnologia, EMBRAPA, Brasília, v. 19, n. 1, p. 37-67, jan.-abr. 2002.

SILVA, Claudia Maria Arantes. Relações de trabalho no espaço rural friburguense: pluriatividade e complexificação das relações sociais de produção (dissertação). Universidade do Estado do Rio de Janeiro, 2008.

SINGER, Paul. Economia politica da urbanização. 13. ed. São Paulo: Editora Brasiliense, 1995.

SMITH, Adam. Riqueza das naçôes. Rio de Janeiro: Tecnoprint, 1986. 
SMITH, Neil. Desenvolvimento desigual. Rio de Janeiro: Bertrand Brasil, 1988.

SOBARZO, Oscar. "O urbano e o rural em Henri Lefebvre". In SPOSITO, Maria Encarnação Beltrão e WHITACKER, Arthur Magon (orgs.). Cidade e campo: relações e contradiçôes entre urbano e rural. 1. ed. São Paulo: Expressão Popular, 2006.

SOLARI, Aldo. “O objeto da sociologia rural”. In SZMRECSÁNYI, Tamás e QUEDA, Oriowaldo (orgs.). Vida rural e mudança social. 3. ed. São Paulo: Editorial Nacional, 1979, p. 3-14.

SOUZA, Sonale Vasconcelos de. Relação cidade-campo: permanência e recriação dos subespaços rurais na cidade de Campina Grande-PB (dissertação). UFPB, 2013.

SPOSITO, Maria Encarnação. "A produção do espaço urbano: escalas, diferenças e desigualdades socioespaciais". In CARLOS, Ana Fani A. et al. A produção do espaço urbano: agentes e processos, escalas e desafios. São Paulo: Contexto, 2011, p. 123-46.

VALE, Ana Rute do. Expansão urbana e plurifuncionalidade no espaço periurbano do municipio de Araraquara (SP) (tese). Universidade Estadual Paulista, 2005.

WILLIAMS, Raymond. $O$ campo e a cidade: na história e na literatura. São Paulo: Companhia das Letras, 2011.

WIRTH, Louis. "O urbanismo como modo de vida”. In VELHO, Otávio Guilherme. O fenômeno urbano. 2. ed. Rio de Janeiro: Zahar Editores, 1973. 



\section{Capítulo 3}

\section{A possibilidade de levantar dados sobre a percepção espacial do rural e do urbano no Brasil}

Gabriel Bias-Fortes

Glaucio José Marafon

O levantamento do espaço rural e urbano no Brasil é atualmente realizado pelo Instituto Brasileiro de Geografia e Estatística (IBGE) a partir de critérios político-administrativos (na adequação da malha de setores censitários às legislações municipais) ou morfológicos (pela adoção do perímetro urbano para fins estatísticos em caráter residual), conforme metodologia do Censo Demográfico de 2010 (IBGE, 2016). Nessa metodologia, o território brasileiro é classificado em áreas rurais e áreas urbanas conforme a aplicação de um dos critérios na fragmentação do território em setores censitários. Apesar da recente elaboração de novos critérios de identificação de espaços rurais e urbanos no Brasil (IBGE, 2017), não há - em escala nacional - um procedimento que viabilize o levantamento do espaço geográfico percebido pelas pessoas.

Ao analisar o espaço (rural e urbano) percebido pelas pessoas, considera-se uma interpretação espacial diversa do que é preestabelecido pelo poder público, da associação pura com a produção e a atividade econômica, ou ainda da forma morfológica e estrutural presente nesses espaços, tendo em vista que uma mesma forma pode evocar percepções individuais distintas em virtude das experiências e das concepções de cada pessoa.

Nessa dimensão do espaço percebido, as ideias de rural e urbano se apresentam como abstrações sustentadas no imaginário do coletivo, criando paradigmas no entendimento desses espaços. São, assim, uma construção social elaborada pela percepção dos indivíduos, que, segundo Guerra (1993), é fundamentada tanto pelo quotidiano (espaço vivido pelo sujeito) quanto pelo imaginário social 
(relacionado às conjunturas históricas e a representações desejáveis). Entende-se, portanto, que o espaço pode ser interpretado e representado segundo a ótica do sujeito que o percebe. Assim, ao trazer essa premissa para a temática que envolve os espaços rurais e urbanos, questiona-se a possibilidade de realizar um levantamento que captasse a percepção espacial das pessoas sobre o rural e o urbano.

Nesse aspecto, concorda-se com Rocha (2002, p. 75) que "a percepção é a forma como, através dos sentidos, as coisas do mundo natural ou humano chegam à consciência" (Rocha, 2002, p. 75). A percepção espacial seria, portanto, a forma como determinados espaços são compreendidos e interpretados pelas pessoas.

A associação desse entendimento com a fenomenologia e a geografia da percepção ocorre principalmente em conformidade com as investigações de Merleau-Ponty (2014), em que a percepção espacial do sujeito ocorre, de forma indissociável, tanto pelo conhecimento prévio e concepção do mundo exterior (que se faz presente independentemente do sujeito) quanto pela interpretação e identificação íntima que esse sujeito faz deste mundo exterior. Para o autor:

Deve-se dizer que é sob o mesmo ponto de vista: eu compreendo o mundo porque para mim existe o próximo e o distante, primeiros planos e horizonte, e porque assim o mundo se expõe e adquire um sentido diante de mim, quer dizer, finalmente porque eu estou situado nele e ele me compreende. Nós não dizemos que a noção do mundo é inseparável da noção do sujeito, que o sujeito se pensa inseparável da ideia do corpo e da ideia do mundo, pois, se só se tratasse de uma relação pensada, por isso mesmo ela deixaria subsistir a independência absoluta do sujeito enquanto pensador e o sujeito não estaria situado. Se o sujeito está em situação, se até mesmo ele não é senão uma possibilidade de situações, é porque ele só realiza sua ipseidade sendo efetivamente corpo e entrando, através deste corpo, no mundo. Se, refletindo na essência da subjetividade, eu a encontro ligada à essência do corpo e à essência do mundo, é porque minha essência como subjetividade é uma e a mesma que minha existência como corpo e com a existência do mundo, e porque finalmente o sujeito que sou, concretamente tomado, é inseparável deste corpo-aqui e deste mundo-aqui (Merleau-Ponty, 2014, p. 547).

Observa-se que essa abordagem se aproximaria desta compreensão dos espaços urbanos e rurais a partir da percepção individual e da identidade com o ambiente, buscando o entendimento desses espaços a partir de uma perspectiva 
simbólica, experimental e fenomenológica, na qual cada indivíduo que interage com o ambiente expõe sua compreensão de rural ou urbano. Essa identidade, abordada em Guerra (1993), é construída num processo dinâmico, no qual os modos de vida são organizados pela percepção individual da realidade (de cada sujeito) em consideração ao contexto histórico que envolve o território vivido. Para a autora, os modos de vida são entendidos como um conjunto integrado de práticas articuladas a "representações do mundo" e a "imaginários sociais" (Guerra, 1993, p. 70).

Ao investigar uma identificação de espaços rurais e urbanos (ou mesmo categorias intermediárias entre essas classificações) segundo a concepção das pessoas que habitam e vivem nesses meios, parte-se da análise de um recorte selecionado como um espaço de identificação, simbolismos e subjetividade; da visão individual criada tanto pela experiência e vivência pessoal no ambiente quanto pela vivência coletiva e construção histórica nesse ambiente, concordando com Woods (2005) na ideia de territórios socialmente construídos. Para o autor, que trabalha a identificação desses espaços no "mundo rural" (Woods, 2005), a compreensão da construção social passa pelo caminho em que cada pessoa identifica um lugar, um objeto ou uma ideia por meio da atribuição de características sociais, culturais, estéticas e ideológicas, sendo que essa construção social, ainda que parta de uma reflexão individual, consolida-se somente quando um grupo de pessoas a imagina como tal, sendo, portanto, uma dimensão que, ao mesmo tempo, é individual e coletiva (o conjunto das reflexões).

De forma semelhante, Maia (2015, p. 70) analisa o espaço rural brasileiro a partir de imaginários que se constituem em "uma ação derivada de um significado referente a um conjunto de formas e processos que compõem o espaço geográfico, indicando e impondo ao ser social uma forma de estar neste espaço geográfico". A imaginação geográfica do indivíduo, para o autor, é elaborada por um conjunto de imagens inter-relacionadas que produzem e refletem um imaginário construído socialmente.

Cabe, dessa forma, elaborar formas de captação da percepção geográfica em um dado território analisado, uma vez que essa percepção, em sintonia com Merleau-Ponty (2014), ocorre pela subjetividade na interpretação do mundo exterior. Nesse sentido, cabe a pontuação de Matthews (2010, p. 31) acerca do pensamento de Merleau-Ponty: 
A fenomenologia, como Merleau-Ponty a vê, combina portanto uma forma de subjetivismo com uma forma de objetivismo. É subjetiva por reconhecer que toda experiência é uma experiência de alguém, que a 'aparência das coisas' é sua 'aparência para um 'sujeito' específico'. Uma descrição dos fenômenos, isto é, da aparência das coisas, deve ser necessariamente a descrição de uma experiência subjetiva. Todavia, uma vez que o ser dos sujeitos é um ser-no-mundo, isto é, uma vez que a experiência consiste em estar envolvido no mundo, uma descrição da experiência subjetiva não é a descrição de algo puramente 'interior', mas de nosso envolvimento com um mundo que existe independentemente da experiência que temos dele. $\mathrm{O}$ mundo, diz Merleau-Ponty, não é algo em que meramente pensamos, mas o lugar no qual vivemos nossas vidas, o mundo em que atuamos, sobre o qual temos sentimentos e esperanças, além de ser o mundo que tentamos conhecer.

Assim, pensar no rural e no urbano pelo conjunto das percepções espaciais parte da identificação de cada sujeito que vive nesses territórios, este que forma sua compreensão com base em fatores objetivos e externos (o mundo exterior que independe de sua concepção) e fatores subjetivos (a forma como o sujeito interpreta esse mundo).

Ainda que o levantamento da percepção de cada indivíduo no Brasil acerca de sua localização em espaço rural ou urbano se mostre inviável em razão da operacionalização, o levantamento da percepção no nível domiciliar torna-se possível ao aproveitar a estrutura do Censo Demográfico do IBGE, que possibilitaria uma classificação rural/urbana (complementar à atual) que dialogue com a fenomenologia e a geografia da percepção.

Dessa forma, caberia a elaboração de um procedimento que enumere a percepção espacial do rural e do urbano a partir da concepção do entrevistado, aproveitando a estrutura de divulgação do IBGE no nível do setor censitário ${ }^{12}$ como recorte territorial para divulgação complementar de informações relativas ao rural/urbano. Captar as representações que os cidadãos fazem de seu território é fundamental para identificar elementos do modo de vida da população e auxiliar o planejamento de políticas públicas.

1 O setor censitário, na metodologia do IBGE, é a menor unidade territorial de coleta do instituto (IBGE, 2016, p. 286) formada por área contínua, integralmente contida em área urbana ou rural. Cada setor censitário possui um código de cadastro na base do instituto. 
Nessa proposta metodológica, a intenção é obter uma identificação de ruralidade ou urbanidade por parte de cada sujeito de forma similar ao levantamento do critério de cor ou raça realizado nas operações censitárias do IBGE. Conforme metodologia adotada pelo instituto no Censo de 2010 (IBGE, 2010, p. 285), utiliza-se o método da autodeclaração induzida para obtenção da informação referente a cor ou raça, uma vez que se entende que esse método ocorre quando o entrevistado tem de escolher uma opção dentre um rol predefinido, em comparação ao da autodeclaração espontânea na qual não há categorias predefinidas para a resposta, de acordo com Osório (2003). Ao aplicar esse procedimento para o levantamento do rural e do urbano pela declaração do entrevistado - considerando aspectos logísticos e operacionais -, deve-se estabelecer a busca do dado no nível domiciliar em vez de buscar a opinião de cada residente.

Pela enumeração do critério referente a cor ou raça (eminentemente autodeclaratório) desde os primeiros censos, o IBGE se posiciona no campo fenomenológico na coleta desses dados conferindo uma abordagem perceptiva em cada indivíduo entrevistado e considerando que essa percepção é constituída no âmbito interno (concepções iniciais) e externo (como o indivíduo se vê no contexto em que vive). Nesse entendimento, Longo e Campos (2006, p. 2), ao analisarem as informações relacionadas a cor/raça nas pesquisas domiciliares, consideram que:

[...] a informação de raça/cor que subsidia os estudos sobre diferenças raciais é uma autodeclaração, ou seja, depende da percepção de cada um em relação à sua cor ou raça. Indo além, podemos pensar ainda que esta autodeclaração também pode estar associada de como o indivíduo vê o outro ou até mesmo de como ele imagina ser visto pela sociedade.

Haja vista essa experiência prévia na coleta de dados, seguindo uma abordagem fenomenológica/perceptiva e considerando que o instituto realiza a cada dez anos um censo demográfico no país, ocorre uma oportunidade estratégica para o levantamento da ruralidade/urbanidade por parte dos entrevistados. No censo, operação que realiza a listagem e a atualização de todos os domicílios em cada setor censitário - abordando, para a entrevista, aqueles que se encontram efetivamente ocupados e que servem de residência principal -, sugere-se a inserção de uma pergunta que levante a condição rural/urbana do domicílio pela concepção do morador responsável por responder ao questionário. 
Em resumo, propõe-se incluir no questionário uma pergunta que corresponderia à percepção do rural e do urbano - considerando o recorte territorial no nível do setor censitário, utilizado pelo IBGE como base de coleta operacional de acordo com sua metodologia (IBGE, 2016) - de maneira que se aproveite um procedimento operacional já existente para enumeração da percepção individual rural/urbano (organizada no nível de setor censitário) a partir da inclusão de uma pergunta correlacionada à demanda, como, por exemplo: "O Sr./Sra./Srta. considera que o domicílio se localiza em área rural ou urbana?”.

Observando as limitações operacionais para enumeração da percepção de cada residente do domicílio entrevistado e uma vez que o próprio questionário vincula-se à unidade visitada, a resposta a essa pergunta (na opção rural ou urbana) valeria para todo o domicílio e seus residentes. Da mesma forma que a declaração de cor ou raça no questionário, esse aspecto seria autodeclaratório e, considerando que estaria vinculado ao domicílio e não a cada indivíduo, o levantamento pode corresponder mais a uma alterdeclaração que uma autodeclaração propriamente dita - considerando que a resposta do morador entrevistado valeria para os demais -, conforme exposto por Longo e Campos (2006).

Baseando-se no questionário do Censo Demográfico de 2010 - tanto no questionário básico quanto no questionário da amostra, ambos disponibilizados pelo portal eletrônico do IBGE -, a pergunta sugerida se encaixaria com maior eficácia como a primeira indagação do item 2 do questionário (rol de perguntas relativas às características do domicílio para domicílios particulares permanentes ocupados), conforme pode ser visto na figura 1. As demais perguntas seriam mantidas, de acordo com a sequência do questionário após a inclusão da pergunta sugerida (no caso, a pergunta sugerida se configuraria como o item 2.01, e as demais perguntas do bloco 2 se iniciariam a partir do item 2.02). 
Figura 1 - Identificação, a partir do questionário básico do Censo Demográfico de 2010, do melhor campo de inserção da pergunta referente ao rural/urbano percebido pelo entrevistado

\begin{tabular}{|c|c|c|c|}
\hline 2 & \multicolumn{3}{|c|}{$\begin{array}{c}\text { PARA DOMICÍLIOS PARTICULARES PERMANENTES OCUPADOS } \\
\text { CARACTERÍSTICAS DO DOMICÍLIO }\end{array}$} \\
\hline \multicolumn{4}{|c|}{2.01 - ESTE DOMICILIOE: } \\
\hline & 1 - PRÓPRIO DE ALGUM MORADOR - JÁ PAGO & \multicolumn{2}{|c|}{ 4- CEDIDO POR EMPREGADOR } \\
\hline & 2. PRÓPRIO DE ALGUM MORADOR - AINDA PAGANDO & \multicolumn{2}{|c|}{ 5. CEDIDO DE OUTRA FORMA } \\
\hline & 3. ALUGADO & \multicolumn{2}{|c|}{ 6. OUTRA CONDIÇÃO } \\
\hline \multicolumn{4}{|c|}{ Siga 2.02} \\
\hline \multicolumn{4}{|c|}{$\begin{array}{l}\text { 2.02 - QUANTOS BANHEIROS DE USO EXCLUSIVO DOS MORADORES EXISTEM NESTE DOMICILIO? } \\
\text { (Inclusive os localizados no terreno ou na propriedade) }\end{array}$} \\
\hline & $\begin{array}{l}\text { 1 - BANHEIRO(S) COM CHUVEIRO (OU BANHEIRA) } \\
\text { E VASO SANITÁRIO (OU PRIVADA) }\end{array}$ & & $\begin{array}{l}\text { (Se } 0(\text { zero), siga 2.03. Caso contrário, passe ao 2.04) } \\
\text { (Se } 9 \text { ou mais de } 9 \text {, registre } 9 . \text { Se não existir registre } 0 \text { (zero)) }\end{array}$ \\
\hline \multicolumn{4}{|c|}{$\begin{array}{l}\text { 2.03 - UTLIZIZA SANITÁRIO OU BURACO PARA DEJEÇÕES, INCLUSIVE OS LOCALIZADOS NO TERRENO OU NA PROPRIEDADE? } \\
\text { (Cercado por paredes de qualquer material) }\end{array}$} \\
\hline & 1. SIM (Siga 2.04) & sse ao 2.05) & $\begin{array}{l}\text { Obs.: Dependendo da regiāo do pais, sanitário } \\
\text { pode ser conhecido como: casinha, patente, latrina } \\
\text { privada, sentina, retrete, casa-de-força, cambrone }\end{array}$ \\
\hline
\end{tabular}

Fonte: Org. do autor, 2019.

Nota: Figura elaborada a partir do questionário do Censo Demográfico de 2010.

Com a coleta da informação realizada junto à operação censitária, bastaria o IBGE classificar cada setor censitário em conformidade com parâmetros de classificação rural-urbano pré-definidos em relação ao conjunto de declaraçóes domiciliares acerca da pergunta. Como exemplo para a pesquisa, adotou-se o parâmetro de classificação utilizado em nível regional pela Organização de Cooperação e de Desenvolvimento Econômico (OCDE), exposta por Schneider (2009, p. 2), que traz cortes percentuais que podem ser utilizados para classificação de setores censitários pela percepção em cada domicílio. A adaptação desses parâmetros está resumida no quadro 1:

Quadro 1 - Proposta de parâmetro de classificação do setor censitário conforme o percentual de percepçáo territorial entre rural e urbano

\begin{tabular}{cc}
\hline Classificação & $\begin{array}{c}\text { \% Declaração de localização do } \\
\text { domicílio em área rural }\end{array}$ \\
\hline Perceptível Rural & Acima de $50 \%$ \\
\hline Perceptível Intermediário & $15 \%-50 \%$ \\
\hline Perceptível Urbano & Abaixo de $15 \%$ \\
\hline
\end{tabular}

Fonte: Org. do autor, 2019.

Nota: Adaptação a partir do quadro da OCDE, em Schneider (2009). 
Nessa categorização, o setor censitário estaria classificado como rural, intermediário ou urbano (pelo critério da percepção do entrevistado) em razão do conjunto de declarações domiciliares (localização em área rural ou urbana) em cada setor.

Ao incorporar esses valores estipulados pela OCDE na criação de um parâmetro de classificação do rural/urbano percebido pelo entrevistado, obtém-se uma categoria intermediária que, além de dar origem a um novo universo de pesquisa, rompe com a interpretação dicotômica sobre o tema e, uma vez que o procedimento também utilizaria o setor censitário como base de divulgação, torna-se possível comparar os dados oficias respaldados na metodologia atual de apuração do território rural/urbano com os dados listados a partir dessa metodologia de classificação pela percepção do entrevistado.

Assim, a proposta metodológica exposta se firma: 1) na pergunta sugerida para o levantamento do caráter de ruralidade/urbanidade; 2) na utilização do setor censitário como recorte territorial; 3) nos parâmetros expostos no quadro 1 como critério de classificação; e 4) na estrutura operacional do Censo Demográfico para a coleta das informações.

\section{O teste do procedimento proposto}

Para testar o método, optou-se pela aplicação desse procedimento em três áreas que, apesar de apresentarem características distintas, foram classificadas como áreas urbanas no levantamento do Censo Demográfico de 2010. Essas áreas correspondem a três setores censitários (área operacional de coleta do IBGE): um localizado no distrito do Faria, em Barbacena/MG; outro localizado na Ilha Grande (município de Angra dos Reis/RJ), na localidade conhecida como Abraãozinho ${ }^{23}$; e outro na localidade conhecida como Barra do Sana, em Macaé/RJ - representados, respectivamente, na malha de setores censitários do Censo Demográfico de 2010 pelos setores de geocódigo 310560814000001 , 330010010000005 e 330240340000005 .

2 No setor, há mais de uma localidade cadastrada (Praia da Crena, Praia da Gaxumba, Praia do Morcego, Praia do Sobrado e Sítio do Frederico); a fim de facilitar a análise, optou-se por generalizar na localidade principal - Abraãozinho. 
Em todos os testes (Faria, Abraãozinho e Barra do Sana), utilizou-se da malha censitária de 2010 divulgada pelo IBGE para isolar os "setores-alvo" do procedimento a fim de compor as imagens e mapas usados durante o trabalho de campo. Nessas imagens - com o auxílio do software QGIS versão 2.18 -, optou-se por indicar previamente as construções e prováveis construções para facilitar a orientação no trabalho de campo (figuras 2, 3 e 4).

Figura 2 - Setor censitário referente à localidade (distrito) do Faria, em Barbacena/MG

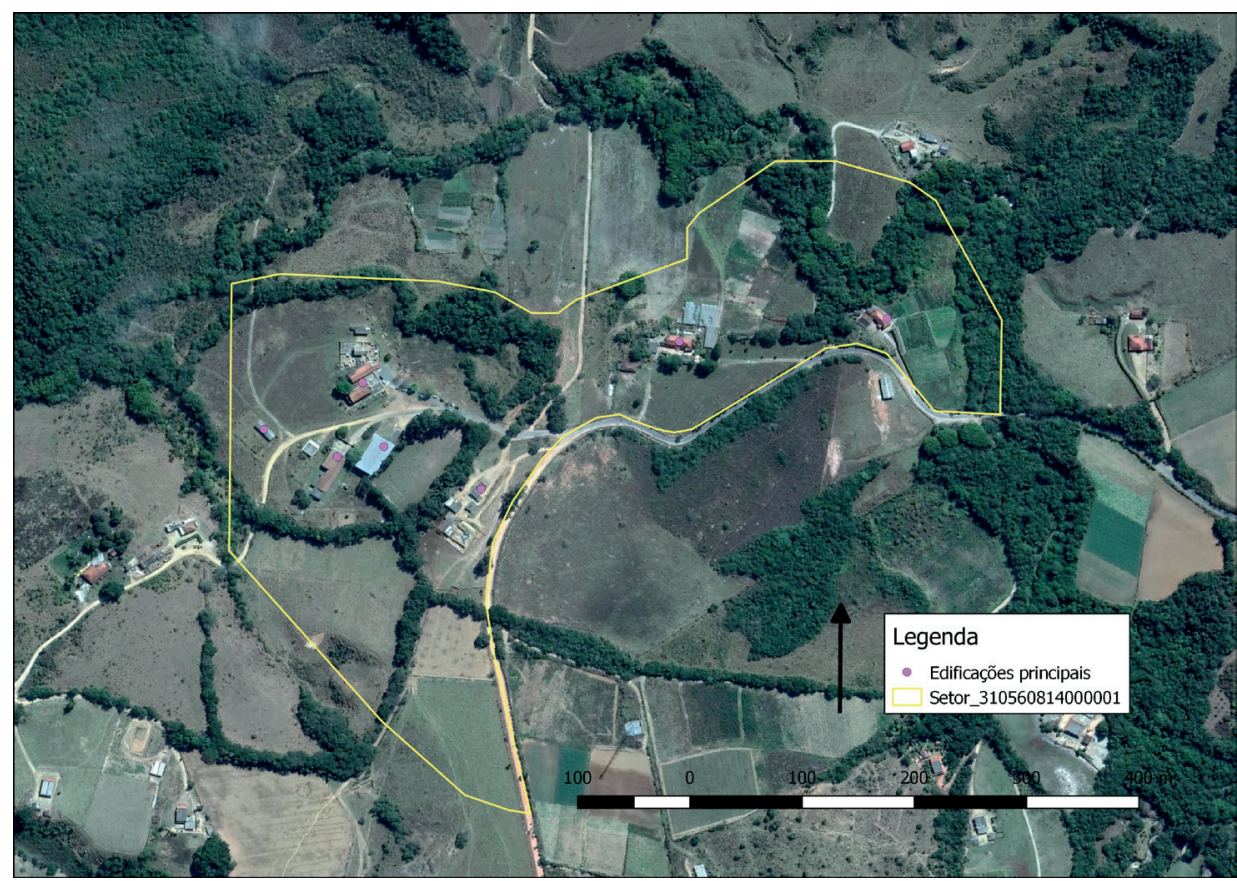

Fonte: Elaborado pelo autor, 2019.

Nota: Elaborado no software QGIS com imagem da camada Google Satelite (geoserviço disponível no software pelo plugin Quickmaps Services).

Além dos mapas e imagens para facilitar a coleta de dados no trabalho de campo, os arquivos gráficos dos setores (originalmente em formato shapefile) foram convertidos para o formato Keyhole Markup Language (KML), de forma a possibilitar a orientação dos pesquisadores pelo uso do aplicativo Google Earth 
no Smartphone (com o localizador ativado). Assim, fora possível identificar a posição do pesquisador referente aos pontos previamente detectados durante os trabalhos de campo.

Figura 3 - Setor censitário referente à localidade de Abraãozinho, em Angra dos Reis/RJ

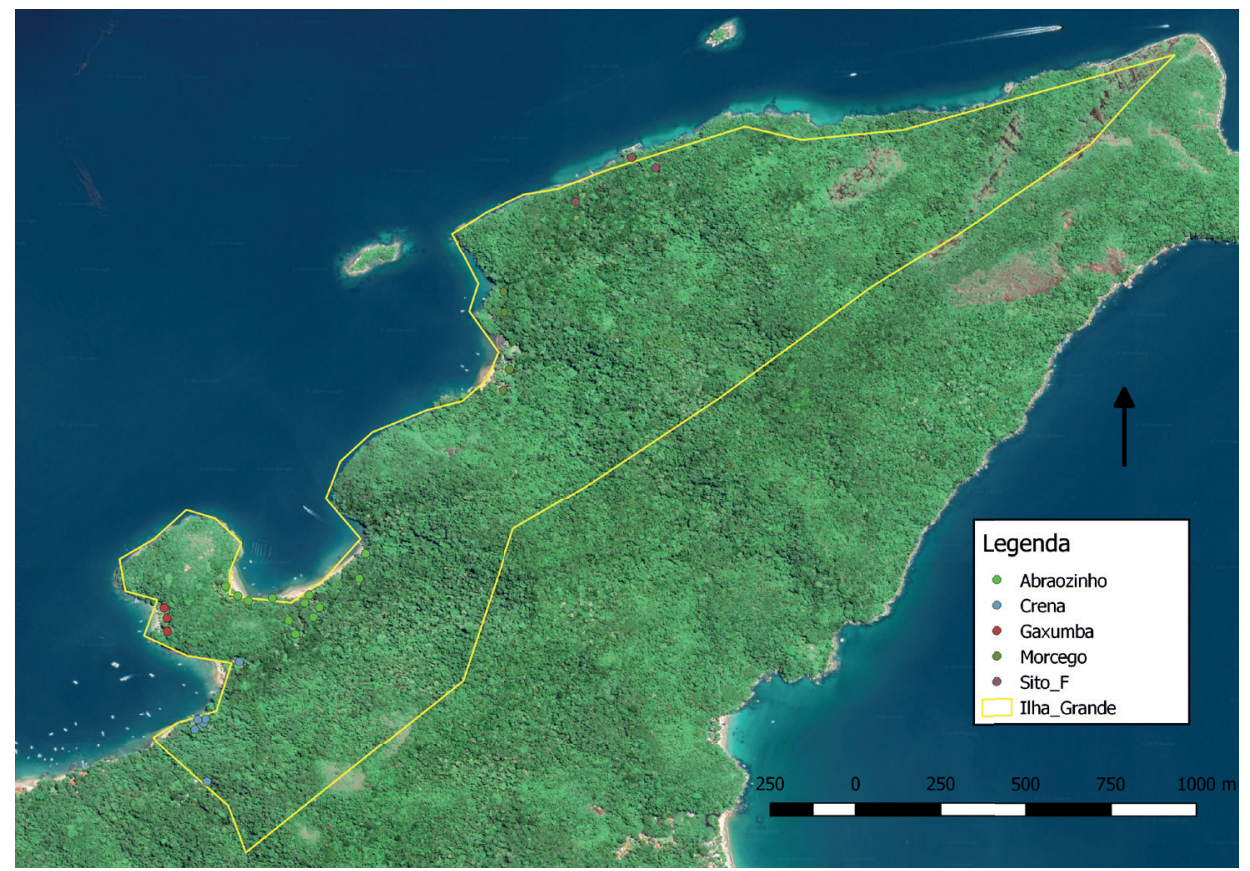

Fonte: Elaborado pelo autor, 2019.

Nota: Elaborado no software QGIS com imagem da camada Google Satelite (geoserviço disponível no software pelo plugin Quickmaps Services). 
Figura 4 - Setor censitário referente à localidade de Barra do Sana, em Macaé/RJ

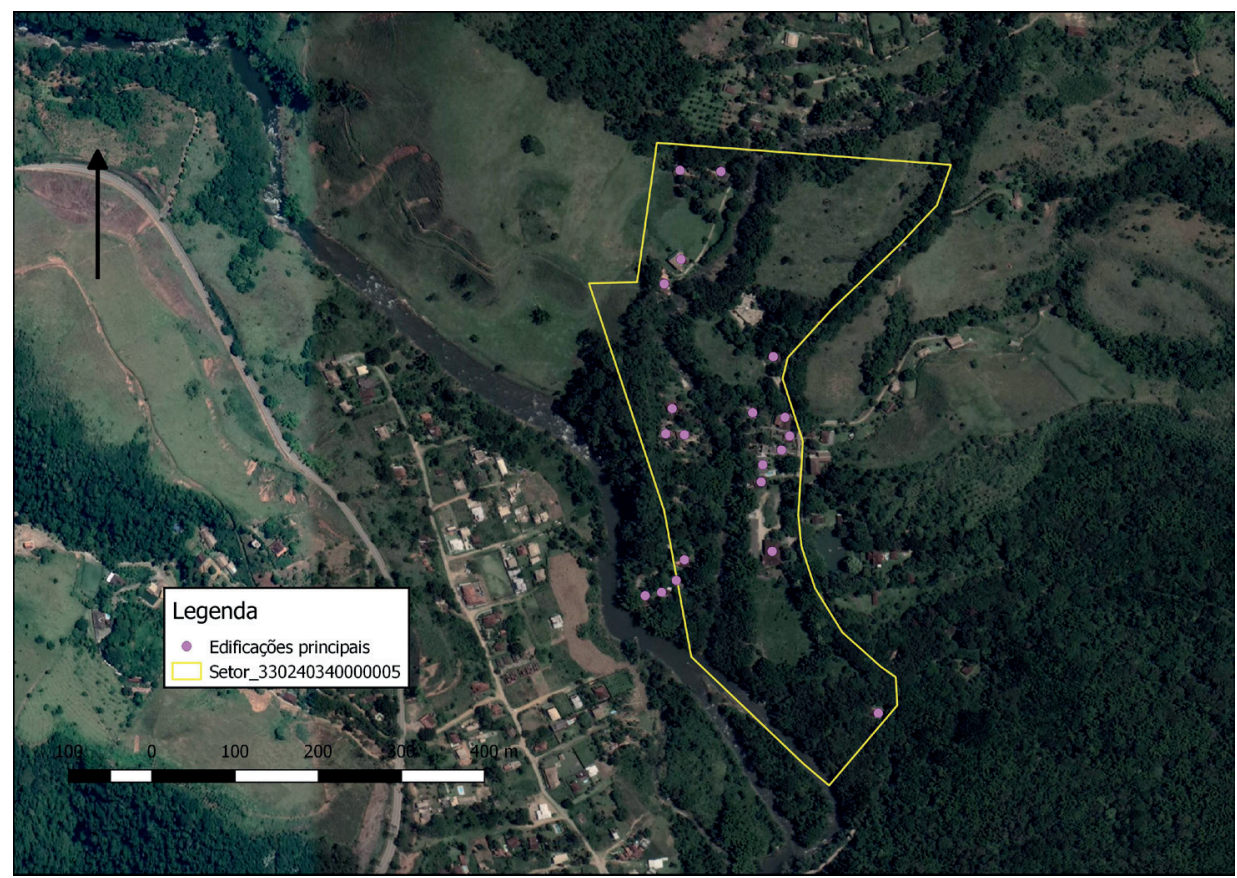

Fonte: Elaborado pelo autor, 2019.

Nota: Elaborado no software QGIS com imagem da camada Google Satelite (geoserviço disponível no software pelo plugin Quickmaps Services).

Ainda que o procedimento vise a obter apenas a percepção da condição rural/urbana do domicílio, é necessário acrescentar ao levantamento algumas informaçóes adicionais para validar a metodologia, pois, tendo em vista que não há de se reaplicar o questionário do Censo Demográfico com a inserção da pergunta, deve-se verificar minimamente dados referentes a idade, profissão e escolaridade e, em especial, se o morador residia no domicílio em 2010; para fins de análise, também são obtidas algumas informaçóes adicionais. Assim, o conjunto de informaçóes levantadas referem-se a:

1. Nome e idade do proprietário do domicílio ou do responsável pelas informaçóes;

2. Profissão e escolaridade do proprietário do domicílio ou do responsável pelas informaçóes; 
3. Tempo de residência no domicílio - uma vez que o levantamento testado refere-se a 2019, apura-se esta informação para permitir a comparação com os dados oficiais referenciados em 2010 (de forma que os dados dos entrevistados que não residiam no domicílio durante o Censo de 2010 não são considerados para fins de comparabilidade);

4. Percepção territorial - se o entrevistado considera o domicílio localizado em área rural ou urbana (pergunta estabelecida na forma proposta anteriormente);

5. Justificativa da percepção territorial - embora não esteja contemplada na proposta geral exposta anteriormente, aproveitou-se o teste para coleta de informaçóes extras que podem vir a auxiliar a compreensão do rural/urbano pela abordagem fenomenológica;

6. Divulgação oficial - se o entrevistado tem algum conhecimento acerca da divulgação oficial do domicílio como urbano, a fim de verificar a possibilidade desse conhecimento prévio interferir na percepção.

A partir da necessidade desses dados, cria-se uma sequência de perguntas elaboradas a fim de se evitar o fornecimento prévio de informaçóes pelo entrevistador que possam vir a afetar a percepção rural/urbano do entrevistado. Essa sequência está disposta no quadro 2.

\begin{tabular}{cc}
\hline \multicolumn{2}{c}{ Quadro $2-$ Sequência de perguntas para o procedimento } \\
\hline Ordem na Sequência & Tema da Pergunta \\
\hline 1 pergunta & Nome \\
\hline 2 pergunta & Idade \\
\hline 3 pergunta & Profissão \\
\hline 4 pergunta & Escolaridade \\
\hline 5 pergunta & Tempo de residência \\
\hline 6 pergunta & Percepção Territorial \\
\hline 7 pergunta & Justificativa \\
\hline 8 pergunta & $\begin{array}{c}\text { Conhecimento prévio da } \\
\text { divulgação oficial }\end{array}$ \\
\hline
\end{tabular}

Fonte: Elaborado pelo autor, 2019. 
O próximo passo consiste no levantamento dos domicílios particulares permanentes ocupados no setor, estes que serviriam de base para a coleta da informação referente ao procedimento sugerido caso fosse aplicado no Censo de 2010 (em conformidade com o que fora exposto). Em consulta à tabela do Cadastro Nacional de Endereços para Fins Estatísticos (CNEFE) - disponível no site do IBGE - referente às unidades visitadas em cada setor na operação de 2010, existiam para o setor na localidade do Faria 4 domicílios particulares num total de 8 endereços ( 1 em construção e 3 estabelecimentos de outras finalidades); já para a localidade de Abraãozinho, existiam 29 domicílios particulares e 2 domicílios coletivos, num total de 35 endereços urbanos (2 em construção e 2 estabelecimentos de outras finalidades). Por fim, na localidade de Barra do Sana, existiam 53 domicílios particulares, num total de 67 endereços urbanos.

Uma vez levantada a situação de cada setor em 2010 (quantitativo de domicílios particulares que serviram como base para a entrevista do Censo), a etapa seguinte refere-se à identificação dos domicílios particulares que atualmente estão ocupados no setor e a coleta das informaçóes propriamente dita - conforme a sequência exposta anteriormente, no quadro 2. Há de se considerar que a coleta de informaçóes é realizada somente nos domicílios particulares, descartando os domicílios coletivos e os demais endereços (que estavam na condição de construção ou estabelecimentos de outras finalidades).

Também deve ser levado em consideração que, após as entrevistas, deve-se utilizar somente as informações referentes aos moradores que habitavam os endereços durante o Censo de 2010, de forma a possibilitar a comparação da informação coletada com a que fora coletada no último Censo. Os dados obtidos nesse levantamento estão compilados e dispostos nos quadros 3 , 4 e 5.3 .

3 A fim de preservar o sigilo do entrevistado, optou-se por substituir o nome do morador pela expressáo Entrevistado 1, Entrevistado 2 etc. 
Quadro 3 - Compilação dos dados coletados em trabalho de campo para o setor no distrito do Faria, em Barbacena/MG - trabalho de campo realizado em $25 / 08 / 2017$

\begin{tabular}{lccc}
\hline Variável $\backslash$ Domicílio & Domicílio 1 & Domicílio 2 & Domicílio 3 \\
\hline Nome & Entrevistado 1 & Entrevistado 2 & Entrevistado 3 \\
\hline Idade & 68 & 55 & 72 \\
\hline Profissão & Produtor Rural & Produtor Rural & Produtor Rural \\
\hline Escolaridade & $\begin{array}{c}\text { Fundamental } \\
\text { incompleto }\end{array}$ & $\begin{array}{c}\text { Fundamental } \\
\text { incompleto }\end{array}$ & $\begin{array}{c}\text { Fundamental } \\
\text { incompleto }\end{array}$ \\
\hline $\begin{array}{l}\text { Tempo de } \\
\text { residência }\end{array}$ & 30 & 55 & 52 \\
\hline $\begin{array}{l}\text { Percepção } \\
\text { territorial }\end{array}$ & Rural & Rural & Rural \\
\hline $\begin{array}{l}\text { Justificativa } \\
\text { Morfológica }\end{array}$ & $\begin{array}{c}\text { Infraestrutura } \\
\text { rural; ausência de } \\
\text { serviços; produção } \\
\text { agropecuária }\end{array}$ & $\begin{array}{c}\text { Pagamento de } \\
\text { imposto rural (ITR) }\end{array}$ \\
\hline $\begin{array}{l}\text { Conhecimento } \\
\text { oficial }\end{array}$ & rural) & Não & Não \\
\hline
\end{tabular}

Fonte: Org. do autor, 2019.

Dos 4 domicílios particulares listados no Censo de 2010 pelo IBGE nesse setor da localidade de Faria (conforme divulgação mencionada anteriormente), identificaram-se 3 endereços com moradores no trabalho de campo. Nesses endereços, todos os 3 moradores foram encontrados e residiam no domicílio há mais de 10 anos, de forma que as declaraçóes dos 3 tornam-se válidas para fins de comparação com o que fora levantado oficialmente em 2010.

Quadro 4 - Compilação dos dados coletados em trabalho de campo para o setor na localidade de Abraãozinho, em Angra dos Reis/RJ - trabalho de campo realizado em 24/08/2019

\begin{tabular}{lccc}
\hline Variável $\backslash$ Domicílio & Domicílio 1 & Domicílio 2 & Domicílio 3 \\
\hline Nome & Entrevistado 1 & Entrevistado 2 & Entrevistado 3 \\
\hline Idade & 55 & 58 & 74 \\
\hline Profissão & Fotógrafo & Jardineiro/Caseiro & Jardineiro/Caseiro \\
\hline
\end{tabular}




\begin{tabular}{|c|c|c|c|}
\hline Escolaridade & Superior completo & $\begin{array}{c}\text { Fundamental } \\
\text { incompleto }\end{array}$ & Alfabetizado \\
\hline $\begin{array}{l}\text { Tempo de } \\
\text { residência }\end{array}$ & 15 & 20 & 50 \\
\hline $\begin{array}{l}\text { Percepção } \\
\text { territorial }\end{array}$ & Rural & Rural & Rural \\
\hline Justificativa & $\begin{array}{c}\text { Maior contato com a } \\
\text { natureza }\end{array}$ & $\begin{array}{l}\text { Distância e } \\
\text { acessibilidade }\end{array}$ & $\begin{array}{c}\text { Ritmo menos } \\
\text { acelerado; área de } \\
\text { proteção ambiental }\end{array}$ \\
\hline $\begin{array}{l}\text { Conhecimento } \\
\text { prévio da divulgação } \\
\text { oficial }\end{array}$ & Não & Não & Não \\
\hline Variável $\backslash$ Domicílio & Domicílio 4 & Domicílio 5 & $\mathbf{X}$ \\
\hline Nome & Entrevistado 4 & Entrevistado 5 & $\mathrm{X}$ \\
\hline Idade & 51 & 38 & $\mathrm{X}$ \\
\hline Profissão & $\begin{array}{c}\text { Caseiro/Serviços } \\
\text { Gerais } \\
\end{array}$ & Marinheiro & $\mathrm{X}$ \\
\hline Escolaridade & $\begin{array}{c}\text { Fundamental } \\
\text { completo }\end{array}$ & $\begin{array}{c}\text { Fundamental } \\
\text { incompleto }\end{array}$ & $\mathrm{X}$ \\
\hline $\begin{array}{l}\text { Tempo de } \\
\text { residência }\end{array}$ & 44 & 20 & $\mathrm{X}$ \\
\hline $\begin{array}{l}\text { Percepção } \\
\text { territorial }\end{array}$ & Rural & Rural & $\mathrm{X}$ \\
\hline Justificativa & Infraestrutura rural & $\begin{array}{l}\text { Infraestrutura rural e } \\
\text { comércio reduzido }\end{array}$ & $\mathrm{X}$ \\
\hline $\begin{array}{l}\text { Conhecimento } \\
\text { prévio da divulgação } \\
\text { oficial }\end{array}$ & Não & Não & $\mathrm{X}$ \\
\hline
\end{tabular}

Fonte: Org. do autor, 2019.

Dos 29 domicílios particulares listados no Censo de 2010 pelo IBGE, identificaram-se 16 domicílios particulares no trabalho de campo, sendo que destes foram encontrados 11 domicílios com moradores (nos quais foi possível realizar a entrevista), 4 domicílios sem morador e 1 domicílio cujo responsável optou por não participar da pesquisa. As demais edificações na área correspondiam a casas de veraneio, aluguel por temporada, estabelecimentos comerciais, pousadas etc. Dos moradores entrevistados, somente 5 residiam na localidade há mais de 10 anos, de forma que suas declaraçóes podem ser utilizadas na pesquisa e comparadas ao levantamento oficial de 2010. 
Quadro 5 - Compilação dos dados coletados em trabalho de campo para o setor na localidade de Barra do Sana, em Macaé/RJ - trabalho de campo realizado em 05/10/2019

\begin{tabular}{|c|c|c|c|}
\hline VariávellDomicílio & Domicílio 1 & Domicílio 2 & Domicílio 3 \\
\hline Nome & Entrevistado 1 & Entrevistado 2 & Entrevistado 3 \\
\hline Idade & 35 & 56 & 59 \\
\hline Profissão & Empresária & $\begin{array}{c}\text { Trabalhador } \\
\text { autônomo }\end{array}$ & Trabalhador rural \\
\hline Escolaridade & $\begin{array}{c}\text { Fundamental } \\
\text { incompleto }\end{array}$ & $\begin{array}{c}\text { Fundamental } \\
\text { incompleto }\end{array}$ & $\begin{array}{c}\text { Fundamental } \\
\text { incompleto }\end{array}$ \\
\hline $\begin{array}{l}\text { Tempo de } \\
\text { residência }\end{array}$ & 35 & 11 & 30 \\
\hline $\begin{array}{l}\text { Percepçáo } \\
\text { territorial }\end{array}$ & Rural & Urbano & Rural \\
\hline Justificativa & Infraestrutura rural & $\begin{array}{c}\text { Infraestrutura e } \\
\text { serviços turísticos } \\
\end{array}$ & $\begin{array}{c}\text { Maior contato com a } \\
\text { natureza }\end{array}$ \\
\hline $\begin{array}{l}\text { Conhecimento } \\
\text { prévio da } \\
\text { divulgaçáo oficial }\end{array}$ & Não & Não & Não \\
\hline VariávellDomicílio & Domicílio 4 & Domicílio 5 & $\mathrm{X}$ \\
\hline Nome & Entrevistado 4 & Entrevistado 5 & $\mathrm{X}$ \\
\hline Idade & 65 & 64 & $\mathrm{X}$ \\
\hline Profissáo & Empresário & Motorista & $\mathrm{X}$ \\
\hline Escolaridade & Ensino Médio & Superior incompleto & $\mathrm{X}$ \\
\hline $\begin{array}{l}\text { Tempo de } \\
\text { residência }\end{array}$ & 28 & 26 & $\mathrm{X}$ \\
\hline $\begin{array}{l}\text { Percepçáo } \\
\text { territorial }\end{array}$ & Rural & Rural & $\mathrm{X}$ \\
\hline Justificativa & $\begin{array}{c}\text { Infraestrutura rural; } \\
\text { acessibilidade; } \\
\text { contato com a } \\
\text { natureza } \\
\end{array}$ & $\begin{array}{c}\text { Produção } \\
\text { agropecuária; } \\
\text { infraestrutura rural }\end{array}$ & $\mathrm{X}$ \\
\hline $\begin{array}{l}\text { Conhecimento } \\
\text { prévio da } \\
\text { divulgaçáo oficial }\end{array}$ & Não & Não & $\mathrm{X}$ \\
\hline
\end{tabular}

Fonte: Org. do autor, 2019.

Dos 53 domicílios particulares listados no Censo de 2010 pelo IBGE, identificaram-se 12 domicílios particulares no trabalho de campo, sendo que 
destes foram encontrados 6 domicílios com moradores (nos quais foi possível realizar a entrevista), 5 domicílios sem morador e 1 domicílio cujo responsável optou por não participar da pesquisa. As demais edificaçóes na área correspondiam a casas de veraneio, aluguel por temporada, estabelecimentos comerciais, pousadas etc. Dos moradores entrevistados, somente 5 residiam na localidade há mais de 10 anos, de forma que suas declaraçóes podem ser utilizadas na pesquisa e comparadas ao levantamento oficial de 2010.

A partir dos dados coletados e da análise do conjunto das declaraçôes (descartando os levantamentos dos entrevistados que não residiam no setor durante o Censo de 2010), os setores 310560814000001, 330010010000005 estariam classificados como rural pelo critério da percepção espacial dos entrevistados - considerando que os mesmos proprietários/responsáveis pela declaração residiam no domicílio durante o levantamento do Censo de 2010 e declararam a percepção como rural (100\% das entrevistas em ambos os setores). A única resposta obtida que percebe a localidade como urbana fora no setor 330240340000005, mas, ainda assim, o setor seria classificado como rural pelo critério de percepção dos entrevistados (mais de 50\% identificando como rural). Assim, em comparação aos dados oficiais que atribuíram como urbano todo o território (e a populaçáo residente) desses setores, os indivíduos que residem neles identificam a localidade como rural (ainda que por critérios distintos). No quadro 6, observa-se essa comparação entre a classificação do rural/urbano perceptível obtida nesses levantamentos e a classificação oficial referente ao Censo de 2010.

Quadro 6 - Síntese dos levantamentos realizados e comparação à classificação oficial

\begin{tabular}{ccccc}
\hline Setor & $\begin{array}{c}\text { Respostas que } \\
\text { perceberam a } \\
\text { localidade como rural } \\
\text { em relação ao total de } \\
\text { entrevistas válidas }\end{array}$ & $\begin{array}{c}\text { Percentual } \\
\text { atribuído } \\
\text { como Rural }\end{array}$ & $\begin{array}{c}\text { Classificação } \\
\text { pela } \\
\text { Percepção }\end{array}$ & $\begin{array}{c}\text { Classificação } \\
\text { Oficial 2010 }\end{array}$ \\
\hline 310560814000001 & $3 \mathrm{em} \mathrm{3}$ & $100 \%$ & $\begin{array}{c}\text { Perceptível } \\
\text { Rural }\end{array}$ & Urbano \\
\hline 330010010000005 & $5 \mathrm{em} \mathrm{5}$ & $100 \%$ & $\begin{array}{c}\text { Perceptível } \\
\text { Rural }\end{array}$ & Urbano \\
\hline 330240340000005 & $4 \mathrm{em} \mathrm{5}$ & $80 \%$ & $\begin{array}{c}\text { Perceptível } \\
\text { Rural }\end{array}$ & Urbano \\
\hline
\end{tabular}

Fonte: Org. do autor, 2019. 
Ao avaliar esses critérios distintos, que fomentaram a resposta da percepção espacial da localidade como rural, observa-se que, em áreas de produção agropecuária - como na localidade do Faria, em Barbacena/MG -, os moradores tendem a associar "rural/urbano" com infraestrutura, morfologia e atividade econômica - que consequentemente impacta no imposto cobrado. Já em áreas onde predomina a atividade turística - particularmente de ecoturismo -, como nas localidades de Abraãozinho, em Angra dos Reis/RJ, e Barra do Sana, em Macaé/RJ, acrescenta-se esse conjunto de associação espacial ao rural imaginado à ideia de um maior contato com o "ambiente natural" ${ }^{4}$. Nessas localidades, também observa-se uma maior presença de edificaçóes de veraneio ou voltadas para a atividade turística - como casas de aluguel por temporada -, que não se configuram como residência principal.

Ainda há de se considerar, de acordo com a análise sobre rigor e qualidade de pesquisas qualitativas em Cornejo e Salas (2011), a validade do procedimento técnico como uma metodologia viável ao atender critérios como: credibilidade (inerente ao próprio processo participativo na coleta dos dados; relação entrevistador e entrevistado); auditabilidade (os dos coletados são passíveis de confirmação por outro pesquisador; e transferibilidade (o procedimento pode ser aplicado em outro recorte territorial). O procedimento realizado em ambas as localidades atende a tais critérios técnicos e reforça sua qualidade metodológica como uma forma de se buscar identificar o espaço rural/urbano.

O levantamento proposto corresponde a uma maneira complementar de se compreender os espaços rurais e os urbanos a partir da percepção das pessoas que habitam esses espaços. Ainda que o procedimento envolva a coleta em nível domiciliar - em vez de coletar a declaraçáo de cada indivíduo - e, paradoxalmente, um levantamento quantitativo - pela compilação do conjunto de declaraçóes - para fundamentar uma classificação sustentada em critérios perceptivos, o procedimento proposto caracterizaria um grande avanço para a representação participativa do espaço, além de romper com a classificação dicotômica entre rural e urbano ao incluir uma categoria intermediária e criar possibilidades de comparaçáo dos dados levantados por essa metodologia com dados provenientes de outros procedimentos de análise - como o método oficial de identificaçáo do rural e do urbano no Brasil.

\footnotetext{
"Ainda que, tal como a ideia de rural e urbano, a noção de "ambiente natural" seja socialmente construída no imaginário coletivo.
} 


\section{Considerações finais}

Ao utilizar a estrutura do IBGE para o levantamento de dados referentes à percepção territorial do rural e do urbano de cada indivíduo - ao generalizar a declaração em nível domiciliar -, torna-se possível classificar os setores censitários a partir da combinação das declaraçôes domiciliares. Não fora o objetivo da análise levantar qualquer crítica referente ao método de apuração dos territórios (rurais e urbanos) utilizado atualmente no Brasil, uma vez que essa listagem corresponde a uma metodologia consolidada, operacionalmente viável e passível de comparabilidade histórica.

O objetivo da análise foi elaborar um método que, ao utilizar a estrutura logística do IBGE, enumerasse a concepção do rural e do urbano a partir da percepção do responsável (entrevistado) pelas informações do domicílio durante a operação do Censo Demográfico. Reitera-se, portanto, que essa classificação do rural/urbano percebida ocorreria de forma complementar à classificação oficial e aproveitaria o know-how metodológico utilizado na autodeclaração - ou alter-declaração, como foi discutido - de cor/raça utilizada pelo instituto.

Ainda que utilize um método dedutivo que resulte na classificação entre rural/urbano pela lógica quantitativa (disposição proporcional pelo conjunto de declaraçóes), a proposta metodológica busca uma abordagem com teor qualitativo ao dialogar com a fenomenologia e a percepção individual do território, tornando-o parte ativa na compreensão do espaço. Nesse sentido, concorda-se com Nogueira (2005, p. 10244), ao afirmar que náo "se deve pensar nos sujeitos das pesquisas como meros informantes de dados, mas como autores, pois a experiência vivida por eles será a principal fonte de interpretação de nossas reflexôes", e com Pereira et al. (2010, p. 173), que consideram que:

A introdução da fenomenologia na Geografia pressupõe uma abordagem do espaço que considera a percepção do sujeito como integrante e em permanente interação. Assim, o mundo vivido e a subjetividade tornam-se fatores importantes para compreensão do espaço nos estudos geográficos.

Uma vez que a proposta consiste na inclusão de uma pergunta no questionário do Censo Demográfico aplicado pelo IBGE - aproveitando toda a estrutura logística da entidade - que evocasse a percepção do entrevistado sobre 
a associação da localidade com o rural e o urbano, considerando a divulgação do conjunto dessas declaraçóes por setor censitário, entende-se que o método utilizado é dedutivo. Embora essa divulgação ocorra pelo setor censitário, o questionamento associa-se com a localidade/localização do domicílio, de forma que a percepção espacial do entrevistado remete ao lugar - e não ao setor. A aproximação com a fenomenologia e a geografia da percepção ocorre pelo levantamento da compreensão territorial do entrevistado, que está incorporada à subjetividade na forma como este concebe o território, entretanto, não se realiza a descrição e a explicação do fenômeno em si.

A aplicação do procedimento no setor censitário referente às localidades conhecidas como Faria (Barbacena/MG), Abraãozinho (Angra dos Reis/RJ) e Barra do Sana(Macaé/RJ) revela a viabilidade do método como um levantamento complementar do rural/urbano, ainda que generalizado e disposto num gradiente rural-intermediário-urbano como fora sugerido. $\mathrm{O}$ reconhecimento dos domicílios em um levantamento prévio para a coleta posterior dos dados confere ao procedimento uma maior segurança metodológica, tal como levantar o tempo de residência a fim de sustentar a comparação dos dados coletados com os dados oficiais enumerados no Censo Demográfico de 2010.

Apesar de não se constituir em uma abordagem propriamente fenomenológica, essa investigação proporcionaria uma listagem prévia (em nível nacional) para subsidiar análises sobre a percepção do lugar pelas pessoas que o vivenciam e a comparaçáo dos dados oficiais - embasados na lógica do ordenamento territorial pelo poder público - com os dados elaborados pelo conjunto da percepção das pessoas que habitam o território. Nesse sentido, concorda-se com Maia (2015) que, ao identificar o rural e o urbano por aspectos perceptivos, abre-se um caminho para a compreensão além das análises econômicas ou políticas, focalizando o interesse da pesquisa na coexistência simultânea de diversos campos sociais: o econômico, o político e o cultural. Nota-se, portanto, a potencialidade da adoção desse critério como forma de levantamento complementar ao oficial.

\section{Referências}

BIAS FORTES, G. Classificação brasileira do território rural e urbano: alternativas metodológicas e técnicas complementares à classificação atual (dissertação). Universidade do Estado do Rio de Janeiro, 2017. 
CORNEJO, M. e SALAS, N. "Rigor y calidad metodológicos: un reto a la investigación social cualitativa”. Psicoperspectivas: Individuo y Sociedad, v. 10, n. 2, p. 12-34, jan.-jun. 2011. Disponível em: http://www.psicoperspectivas.cl/index.php/psicoperspectivas/article/view/144/174. Acesso em: 13 set. 2017.

GUERRA, I. "Modos de vida: novos percursos e novos conceitos". Sociologia: Problemas e Práticas, n. 13, p. 59-74, 1993. Disponível em: http://sociologiapp.iscte-iul.pt/fichaartigo.jsp?pkid=270. Acesso em: 26 jun. 2017.

IBGE. Metodologia do Censo Demográfico de 2010. 2. ed. Rio de Janeiro: IBGE, 2016. (Série Relatórios Metodológicos, v. 41).

. Disponível em: http://www.ibge.gov.br/home/. Acesso em: 09 mar. 2017.

. Classificação e caracterização dos espaços rurais e rrbanos do Brasil: uma primeira aproximação. Rio de Janeiro: IBGE, 2017.

LONGO, L. A. F. B. e CAMPOS, M. B. "Auto ou alter-declaração?: uma análise da informação de raça/cor nas pesquisas domiciliares”. Anais do XV Encontro Nacional de Estudos Populacionais, ABEP, Caxambu, p. 1-14, 2006. Disponível em: http://www.abep.org.br/publicacoes/index.php/anais/issue/ view/35/showToc. Acesso em: 09 mar. 2017.

MATTHEWS, E. Compreender Merleau-Ponty. Trad. Marcus Penchel. Petrópolis: Editora Vozes, 2010.

MAIA, A. C. O paraíso atrasado: a construção do rural no Brasil através do imaginário geográfico (tese). Universidade Estadual Paulista, 2015.

MERLEAU-PONTY, M. Fenomenologia da percepção. Trad. Carlos Alberto Ribeiro de Moura. 4. ed. São Paulo: WMF Martins Fontes, 2014.

NOGUEIRA, A. R. B. "Uma interpretação fenomenológica na Geografia". Anais do X Encontro de Geógrafos da América Latina, EGAL, São Paulo, p. 10243-62, 2005. Disponível em: http://observatoriogeograficoamericalatina.org.mx/egal10/Teoriaymetodo/Metodologicos/11.pdf. Acesso em: 13 set. 2017.

OSÓRIO, R. G. O sistema classificatório de "cor ou raça” do IBGE. Brasília: IPEA, 2003, texto para discussão n. 996.

PEREIRA, L. A. G. et al. "Geografia fenomenológica: espaço e percepção". Caminhos de Geografia, v. 11, n. 35, p. 173-78, set. 2010. Disponível em: http://www.seer.ufu.br/index.php/caminhosdegeografia/article/ view/16271. Acesso em: 13 set. 2017. 
ROCHA, L. B. "Fenomenologia, semiótica e geografia da percepção: alternativa para analisar o espaço geográfico". Revista da Casa de Geografia de Sobral, v. 4, n. 1, p. 67-79, 2002. Disponível em: http://www.uvanet.br/rcgs/index. php/RCGS/article/view/79. Acesso em: 13 set. 2017.

SCHNEIDER, S. “Território, ruralidade e desenvolvimento". In VELÁSQUEZ LOZANO, Fabio. e MEDINA, Juan Guillermo Ferro (eds.). Las configuraciones de los territorios rurales en el siglo XXI. 1. ed. Bogotá: Editorial Pontifica Universidad Javeriana, 2009, v. 1, p. 67-108.

WOODS, M. Rural geography. Londres: Sage, 2005. 
Parte II

Políticas para os territórios rurais, urbanos e espaços metropolitanos 



\section{Capítulo 4 \\ Mundo rural e biodiversidade: a territorialização das políticas públicas de desenvolvimento rural em Portugal}

Susana Clemente

\section{Introdução}

Desde a sua origem, as políticas da União Europeia (UE) para o desenvolvimento das áreas rurais têm estado intimamente ligadas à agricultura. Até os anos 1990, o desenvolvimento rural não era concebido como domínio de política autônomo, estando, em vez disso, incorporado à política agrícola. Desenvolvimentos socioeconômicos, mudanças estruturais e tecnológicas e sucessivos alargamentos da UE reconfiguraram, no entanto, essa abordagem setorial como restritiva, ampliando o âmbito da noçáo para poder responder, de forma adequada, aos problemas emergentes das áreas rurais (Dax e Kahila, 2011). Se, até um dado momento, a UE entendia não ser necessário fazer uma distinção entre política agrícola e política rural, uma vez que a agricultura era a atividade dominante nas áreas rurais, e o rural era entendido como sendo o agrícola, a partir dos anos 1980, essa assunção foi tida por falaciosa. Não só os espaços rurais se reconfiguraram como multifuncionais, mas também a pluriatividade pareceu ser prática corrente.

Simultaneamente, na afirmação dos seus produtos tradicionais no mercado, os territórios europeus dependentes da agricultura começaram a sofrer um declínio a longo prazo. Numa altura em que a procura de bens alimentares estagnou, devido a um aumento considerável dos excedentes agrícolas e à procura de produtos diferenciados por parte dos consumidores, a consequência natural foi a redução da competitividade das áreas rurais no domínio da pro- 
dução de alimentos. As regiôes periféricas da UE, onde se incluem territórios como Portugal, Espanha e Irlanda, foram as que mais sofreram, na medida em que o estabelecimento do mercado único beneficiou as áreas mais bem posicionadas geograficamente em termos de acessibilidades e transportes. Além desses fatores, a variedade de espaços e padróes rurais não permite que todos os territórios compitam, no mercado mundial, na produçáo de determinados produtos agrícolas. Um duplo movimento se constata: em determinadas regióes, observa-se o estiolamento da agricultura como atividade econômica orientada para o mercado e a aposta na diversificaçáo da base econômica das áreas rurais; noutras, verifica-se a afirmação da agricultura como atividade econômica competitiva e dominante.

A evolução das áreas rurais parece residir, assim, na dissociação do rural em relação ao agrícola e na assunção da sua multifuncionalidade e pluriatividade. Por um lado, as áreas rurais especializam-se a partir não apenas das suas dinâmicas particulares e caraterísticas próprias, mas também das possibilidades de atração que oferecem em termos simbólicos, econômicos e sociais; por outro lado, diversificam-se na partição e complementaridade das suas funções (produtiva, de reserva espacial, de reserva ambiental etc.).

A ideia de que as áreas protegidas poderão servir à requalificação das áreas rurais periféricas da Europa tem sido defendida. Novas abordagens visam a integrar conservação da natureza e desenvolvimento, transformando as áreas protegidas em "paisagens vivas", nas quais são integradas diferentes funçóes, usos e interesses (Mose e Weixlbaumer, 2007). Essa evolução ocorre porque, por um lado, as sociedades modernas tendem a valorizar cada vez mais a natureza e a associá-la nostalgicamente ao "campo" (Mathieu e Jollivet, 1989; Mormont, 1984, 1987) e, por outro lado, porque nas políticas de desenvolvimento traçadas para o mundo rural, no nível da UE, a ênfase colocada no papel dos espaços rurais para a preservação do ambiente e dos recursos naturais deixa entrever o crescimento desses tipos de estratégias e medidas (Figueiredo, 2003, 2008, 2011).

Nesse contexto, o presente capítulo pretende debater o papel do ambiente nas políticas de desenvolvimento delineadas para as áreas rurais em Portugal. Mais especificamente, tendo como pano de fundo a programação agroambiental, procura-se fazer uma análise da transposição de diretivas comunitárias de desenvolvimento em áreas rurais classificadas para a realidade portuguesa. 


\section{Conservação da natureza e da biodiversidade na União Europeia: a rede Natura 2000}

Até meados dos anos 1990, a política de conservação da natureza constitui um elemento indissociável da política ambiental desenvolvida pela UE. É com a criação, em 1992, da rede Natura 2000, que a UE lança o instrumento que ainda hoje constitui o núcleo da sua política de conservação da natureza e da biodiversidade e, simultaneamente, o seu enquadramento legal. A rede Natura 2000 resulta da implementação das Diretivas "Aves"11 e "Habitats" e pretende ser uma rede ecologicamente coerente de áreas protegidas de importância para a União Europeia.

A Diretiva “Aves”, adotada inicialmente em 1979, destina-se a proteger as aves que vivem naturalmente em estado selvagem no território dos Estados-Membros, bem como os seus ovos, ninhos e habitats (artigo 1. ${ }^{\circ}$ ). De forma geral, os Estados-Membros instituem um regime de proteção de todas as espécies de aves. Para o efeito, têm que classificar como Zonas de Proteção Especial (ZPE) os territórios marítimos e terrestres considerados mais apropriados, em número e em extensão, para a conservação das espécies que constam do anexo I da Diretiva - nomeadamente, espécies ameaçadas de extinção, espécies vulneráveis a certas alterações dos seus habitats, espécies consideradas raras ou outras espécies cujo habitat seja único (artigo 4. ${ }^{\circ}$, inciso 1 ).

Com a adoção, em 1992, da Diretiva "Habitats", o âmbito da política de conservação da natureza e da biodiversidade da UE alarga-se, passando a incluir outros habitats naturais, bem como a fauna e a flora selvagens ameaçadas. Essa diretiva tem por objetivo favorecer a manutenção da biodiversidade por meio da conservação dos habitats naturais, da fauna e da flora selvagens no território dos Estados-Membros (artigo 2..$^{\circ}{ }^{2}$. Para o efeito, é estabelecida para cada uma das regiões biogeográficas da União uma rede de Zonas Especiais de Conservação (ZEC), que compreende os locais que abranjam um ou vários tipos de habitats naturais prioritários que figuram no anexo I, ou uma ou várias espécies prioritárias que constam do anexo II da Diretiva (artigo 3. ${ }^{\circ}$, alínea 1).

Nesse sentido, os objetivos fundamentais da rede Natura são a manutenção da biodiversidade, a proteção e a conservação dos habitats de espécies

Diretiva 2009/147/CE, do Parlamento Europeu e do Conselho, de 30 de novembro de 2009.

2 Diretiva 92/43/CEE, do Conselho, de 21 de maio de 1992. 
de aves, dos habitats naturais e dos habitats de espécies da flora e da fauna, considerados ameaçados ou significativos no espaço da União, assegurando-lhes um estatuto de conservação favorável. Tendo em vista a execução desses objetivos, aos Estados-Membros compete listar ZPE, no âmbito da Diretiva "Aves", e SIC, ao abrigo da Diretiva "Habitats". A partir das várias listas nacionais de SIC, serão posteriormente selecionadas ZEC.

Atualmente, a rede Natura 2000 cobre cerca de 18\% do território terrestre e 9\% do território marinho da UE 28, num total de 27,863 áreas classificadas $(\mathrm{SIC} \text { e ZPE })^{3}$.

\section{A Integração da Conservação da Natureza e da Biodiversidade nas políticas rurais da União Europeia}

As transformaçóes que os espaços rurais europeus sofreram ao longo de quase cinco décadas tiveram fortes implicações na concepção das políticas de desenvolvimento da UE. Entre outros aspectos, a evolução das perspectivas de desenvolvimento para os espaços rurais não é separável da crescente visibilidade das questôes ambientais. A apresentação do Relatório Brundtland e a consequente adoção, em 1987, do princípio de desenvolvimento sustentável estimularam uma renovada discussão de alternativas ao desenvolvimento, com enfoque na sustentabilidade (Friedmann, 1996). A percepção dos problemas ambientais evidenciou a necessidade de uma transformação global da sociedade, ao reconhecer-se que o modelo de desenvolvimento fundado exclusivamente no crescimento econômico não é compatível com a proteção do ambiente.

Relativamente às áreas rurais, isso significa a promoção de um desenvolvimento rural sustentável. O espaço rural surge como espaço passível de assimilar um modelo de desenvolvimento que englobe as variáveis ambientais, uma vez que a retraçáo da agricultura, como principal setor de atividade, tem chamado a atenção para a necessidade de diversificação das atividades em espaço rural, e para a sua integração na designada "fileira do ambiente e patrimônio" (Capucha, 1996).

\footnotetext{
3 As áreas protegidas da rede Natura 2000 podem ser classificadas simultaneamente (total ou parcialmente), ao abrigo das duas diretivas (Aves e Habitats). Nesse sentido, o valor apresentado é um valor corrigido, de modo a evitar sobreposiçóes (valores em março de 2019).
} 
Essa mudança de paradigma implica que a conservação da natureza deixa de ser entendida como política estática e setorial, aplicada a determinadas áreas e a determinadas espécies, para se configurar como política pensada em larga escala, aplicada não só aos espaços protegidos, como também aos territórios circundantes, e integrada com outras políticas setoriais (Hammer, 2007), dentre as quais se destaca a política agrícola.

$\mathrm{Na}$ análise do processo de integraçáo do ambiente na agricultura, dois modelos emergem, intermitentemente, nos campos acadêmico e político (Lowe e Baldock, 2000): o "modelo do impacto" e o "modelo dos bens públicos". O primeiro modelo diz respeito às externalidades ambientais negativas de origem agrícola, sobretudo as de input à atividade (por exemplo, o incentivo ao uso de fertilizantes e ao encabeçamento animal), ligadas aos sistemas de intensificação agrícola. Nesse modelo, considera-se que a atividade agrícola atua em sentido contrário às preocupaçôes ambientais, pelo que se assume que uma redução na intensificação da produção trará benefícios à qualidade ambiental. As medidas de política são concebidas em vista da regulação da intensidade agrícola. $\mathrm{O}$ segundo modelo refere-se às externalidades ambientais positivas de origem agrícola, ligadas aos sistemas de extensificação agrícola. O modelo dos bens públicos parte da premissa de que há uma relação estreita entre certas caraterísticas dos sistemas, ou práticas, agrícolas e certos valores ambientais. E sugere, por seu turno, uma relação mais complexa e indeterminada entre ambiente e agricultura, com implicaçóes menos claras. As medidas de política colocam a tônica nos sistemas agrícolas de alto valor natural e no apoio e na manutenção da agricultura extensiva, especialmente em regióes em que as ameaças ambientais resultam do declínio, ou abandono, agrícola.

Simultaneamente, tem havido um incremento significativo da forte relação entre a produção agrícola e a conservação da diversidade biológica. Por um lado, tem sido reconhecido que a mudança no uso dos solos agrícolas é uma das principais causas do declínio da biodiversidade na Europa - nas terras com solos de melhor qualidade agrícola, os sistemas de cultivo intensificaram-se; as terras com solos mais pobres foram sujeitas ao abandono ou à florestação. Por outro lado, tem sido igualmente reconhecido que a biodiversidade da Europa está indissociavelmente ligada aos sistemas de cultivo tradicionais de baixa intensidade agrícola, criando, assim, valiosos ecossistemas agrícolas em toda a Europa (EEA, 2010). 
De fato, a Superfície Agrícola Utilizada (SAU) cobre um total de cerca de 178 milhóes de hectares, correspondendo aproximadamente a 40\% do território total da UE 28 (EC, 2018), e a sua gestão tem impactos substanciais, positivos e negativos, no funcionamento dos sistemas naturais. Ao longo do tempo, a agricultura tem contribuído para a criação de uma variedade rica de habitats e paisagens, incluindo habitats seminaturais de elevado valor em biodiversidade. No entanto, as mudanças estruturais na agricultura, na segunda metade do século XX, levaram ao aumento da intensificação, da concentração e da especialização da produção em algumas áreas, e à marginalização e abandono noutras, redundando em perdas significativas de biodiversidade em todo o espaço natural cultivado. Essas tendências têm impacto não só na biodiversidade das terras agrícolas, mas também na provisão de diversos serviços ecossistêmicos relacionados com a agricultura, tais como a qualidade da água, do solo e do ar (Poláková et al., 2011).

A UE tem colocado a ênfase quer no ajustamento ${ }^{44}$ da atividade agrícola, quer na proteção e na preservação do ambiente em meio rural. Trata-se de redefinir os mecanismos de apoio à agricultura, nomeadamente, no nível da Política Agrícola Comum (PAC), bem como de criar instrumentos de política específicos para o desenvolvimento em meio rural. Assim, de uma situação de clara ausência nas políticas aplicadas em espaço rural, o setor do ambiente passa para o plano central, consubstanciando as políticas e os programas de desenvolvimento rural:

Podemos dizer, de um modo simplista, que passamos de um contexto em que o ambiente era contra o rural [...] para um contexto institucional que coloca o ambiente a favor do rural, como vantagem das áreas rurais (especialmente nas mais marginalizadas), e coloca o rural como espaço natural por excelência (Figueiredo, 2003, p. 250).

$4 \mathrm{O}$ ajustamento refere-se à modernização agrocomercial da exploração ou da empresa agrícola, como consequência de critérios de preço, qualidade e tempo, que a concorrência, interna e internacional, mais tarde ou mais cedo, acaba por impor (Covas, 1997). 
Figura 1 - Domínios de intervenção da Política Agrícola Comum (PAC)

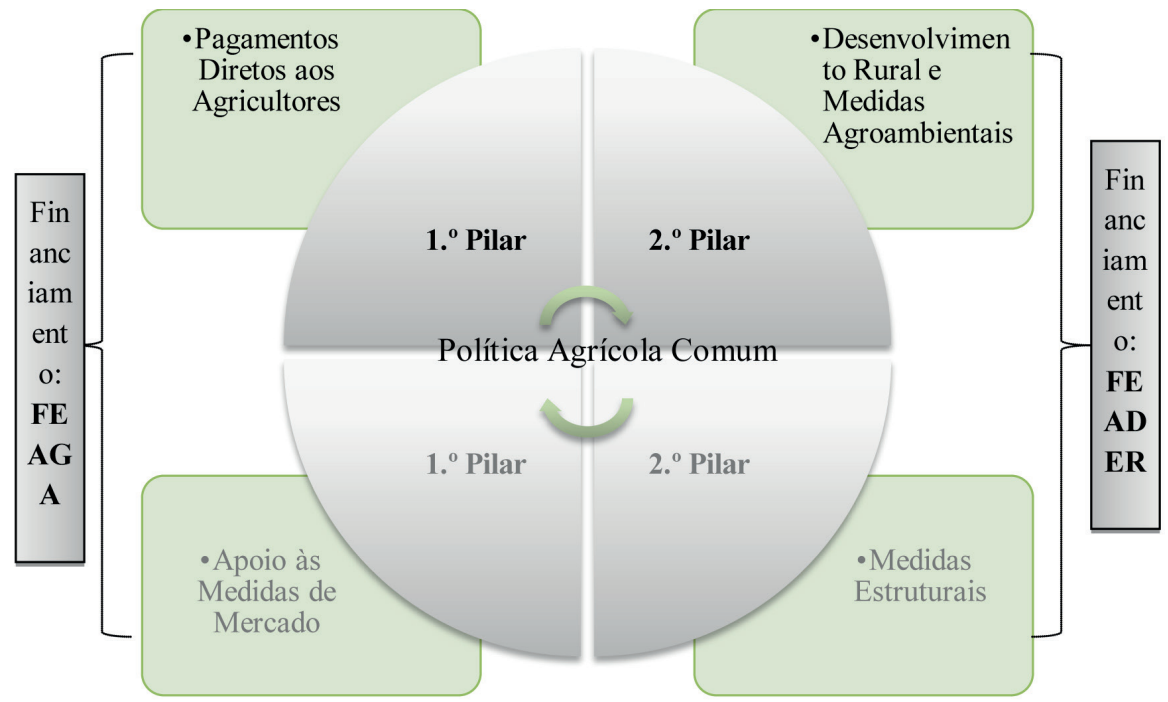

Fonte: Elaboração própria.

Nesse contexto, o primeiro passo para a integração da política de ambiente na política agrícola deu-se com a reforma da PAC de 1992, nomeadamente com a aprovaçáo do Regulamento CEE n. ${ }^{\circ} 2.078 / 92$, relativo a métodos de produção agrícola compatíveis com as exigências da proteção do ambiente e com a preservação do espaço natural. Esse regulamento constituiu a primeira enunciação completa de uma política agroambiental no âmbito da PAC (Arnalte et al., 1998; Lowe e Baldock, 2000). A ideia era que o papel dos agricultores na proteção do ambiente natural e na conservação de paisagens tradicionais fosse plenamente reconhecido e remunerado em conformidade.

Mais tarde, em 1999, com a reforma da Agenda 2000 e a constituição da Política de Desenvolvimento Rural (PDR) como segundo pilar da PAC, a multifuncionalidade da agricultura emergiu como um dos princípios políticos principais. Ou seja, sob o conceito de multifuncionalidade, passaram as ligaçóes entre ambiente, agricultura e desenvolvimento das áreas rurais a colocar-se com acuidade acrescida. Entre as várias funçóes da agricultura, a de preservação do ambiente rural constituía o núcleo central das várias medidas propostas.

A partir, sobretudo, da reforma de 2003, os sistemas de apoio da PAC alteraram-se substancialmente para reforçar a integração do domínio ambiental no domínio agrícola. Igualmente, a prioridade estratégica da UE de travar o 
declínio da biodiversidade tem servido à criação de instrumentos que promovam a integração da conservação da natureza e biodiversidade na PAC. No segundo pilar, entre outras regras, os Estados-Membros têm que assegurar que os programas de desenvolvimento rural propostos cumprem a legislação ambiental e, em particular, as diretivas "Aves" e "Habitats", de modo a prevenir, e minimizar, os potenciais danos à biodiversidade.

\section{Tabela 1 - Evolução Da Política Agrícola Comum (PAC)}

Anos 60 - Instituição da PAC com os objetivos de fornecer alimentos a preços

Fase 1 acessíveis para os cidadãos da UE e um padrão de vida justo para os agricultores. Constituem os seus princípios básicos: i) unicidade do mercado agrícola; ii) preferência comunitária; e iii) solidariedade financeira.

Anos 80 - Orientação de redução da produção agrícola, com o propósito não só

Fase 2 de diminuir os excedentes agrícolas, mas também de reduzir os impactos da sua intensificação no ambiente. Criação da política estrutural de desenvolvimento rural.

Anos 90 - Substituição da garantia de preços e de mercados por ajudas diretas aos

Fase 3 agricultores; esta alteração significa a separação entre a política de preços e mercados e a política de rendimentos. Emergência da PDR como $2 .^{\circ}$ pilar da PAC e criaçáo da política agroambiental.

Anos 2000 - Introduçáo de um pagamento único por agricultor, de acordo com os critérios de ecocondicionalidade (produção sujeita a novas medidas ambientais,

Fase 4 de qualidade e bem-estar dos animais); cumprimento obrigatório das regras de ecocondicionalidade no $1 .^{\circ}$ Pilar e alargamento das regras de ecocondicionalidade ao 2. ${ }^{\circ}$ Pilar.

Pós-2013 - A provisão de bens ambientais públicos está na base da legitimidade da nova PAC. Nesta perspetiva, os agricultores devem ser recompensados pelos serviços

Fase 5 ambientais que prestam ao público mais vasto. O pagamento "verde" (pagamento para práticas agrícolas benéficas para o clima e o ambiente), novo instrumento de política obrigatório, constitui a grande alteração na arquitetura global da política.

Fonte: Elaboração própria

Atualmente, a PAC continua estruturada em dois pilares que diferem no que concerne a sua estrutura, funcionamento e financiamento. Os pagamentos diretos aos agricultores, principal instrumento do primeiro pilar, são, desde 2005, sujeitos à aplicaçáa e ao cumprimento obrigatório das regras de 
"ecocondicionalidade", isto é, ao cumprimento das diretivas ambientais da UE e à manutenção das terras em boas condiçóes agrícolas e ambientais. No segundo pilar, ou PDR, as questôes relacionadas com o ambiente, a conservação da natureza e da biodiversidade são abordadas por meio de instrumentos específicos, dentre os quais se destacam os pagamentos aos agricultores sujeitos a restriçôes de utilização agrícola em zonas com condicionantes ambientais, os pagamentos agroambientais, ou os pagamentos Natura 2000. Os compromissos assumidos devem ir além das boas práticas agrícolas.

Tabela 2 - Instrumentos da política de desenvolvimento rural - articulação entre ambiente, conservação da natureza e biodiversidade

\begin{tabular}{|c|c|c|}
\hline Datas & Instrumento & Orientação \\
\hline 1975 & $\begin{array}{l}\text { Diretiva 75/268/ } \\
\text { CEE do Conselho } \\
\text { de } 28 \text { de Abril de } \\
1975\end{array}$ & $\begin{array}{l}\text { Cria um regime específico de indemnizações compensatórias, } \\
\text { e outras medidas especiais, para a agricultura em zonas de } \\
\text { montanha e outras zonas desfavorecidas, a fim de compensar } \\
\text { as desvantagens naturais permanentes, com vista à prossecução } \\
\text { da atividade agrícola, à manutenção de um mínimo de } \\
\text { povoamento e à conservação do espaço natural. A lógica da } \\
\text { intervenção era a de manter a agricultura nessas zonas, através } \\
\text { de medidas destinadas a favorecer a atividade agrícola e a } \\
\text { melhoria do rendimento dos agricultores, e travar os processos } \\
\text { de êxodo agrícola e rural. }\end{array}$ \\
\hline 1985 & $\begin{array}{l}\text { Regulamento CEE } \\
\text { n. }{ }^{\circ} 797 / 85 \text { do } \\
\text { Conselho de } 12 \text { de } \\
\text { Março de } 1985\end{array}$ & $\begin{array}{l}\text { Define um regime de ajudas nacionais aos agricultores, com } \\
\text { vista a contribuir para a introduçáo, ou para a manutenção, de } \\
\text { práticas de produção agrícola compatíveis com as exigências da } \\
\text { proteçáo do meio ambiente, e assegurar-lhes um rendimento } \\
\text { adequado (artigo } 19 .^{\circ} \text { ). Concretamente, no âmbito do artigo } \\
19 .^{\circ} \text {, os Estados-membros eram autorizados a introduzir } \\
\text { regimes especiais nacionais, em zonas sensíveis do ponto de } \\
\text { vista ambiental, pelo que a sua aplicação era voluntária, e não } \\
\text { era comparticipada pelo orçamento comunitário. }\end{array}$ \\
\hline
\end{tabular}


1992

Regulamento CEE

n. ${ }^{\circ} 2078 / 92$ do

Conselho de 30 de

Junho de 1992

Institui um regime de ajudas para a proteção do ambiente, da paisagem e dos recursos naturais, por via da aplicação de um programa de medidas agroambientais. Mais especificamente, o regulamento constituiu uma das três medidas de acompanhamento da reforma da PAC de 1992, com o objetivo de conceder ajudas para a proteçáo do ambiente, da paisagem e dos recursos naturais (através da aplicação de medidas agroambientais).

Relativo ao apoio do FEOGA (secção Garantia e secção Orientação) ao desenvolvimento rural, junta, num único regulamento, nove regulamentos anteriormente em vigor, com o objetivo de cofinanciar o segundo pilar da PAC. A preservação do ambiente rural constituía o núcleo central das várias medidas propostas no âmbito do regulamento, como, por exemplo, as medidas agroambientais (Capítulo

Regulamento CE

1999 n. ${ }^{\circ} 1257 / 99$ do Conselho de 17 de Maio de 1999 VI), as medidas referentes às zonas desfavorecidas e a regióes com condicionantes ambientais (Capítulo V), à silvicultura (Capítulo VIII), à proteção do ambiente em relação com a agricultura, a silvicultura e a conservação do espaço natural para a promoçăo do desenvolvimento das zonas rurais (Capítulo IX). A estas juntavam-se, de forma indireta, as medidas relativas aos investimentos nas exploraçóes agrícolas que satisfizessem as normas mínimas de ambiente, higiene e bem-estar dos animais (Capítulo I), ou as referentes à formação, com vista à preparação dos agricultores para a aplicação de métodos de produção compatíveis com a manutenção e a valorizaçáo da paisagem, e com a proteçẫo do ambiente (Capítulo III).

Introduz algumas alteraçóes no apoio do FEOGA ao desenvolvimento rural, com a ampliação das regras de ecocondicionalidade às medidas de desenvolvimento rural, Regulamento CE alterando assim o Regulamento CE n. ${ }^{\circ}$ 1257/99. Com

n. ${ }^{\circ} 1783 / 2003$ do

Conselho de 29 de Setembro de 2003 este regulamento, passaram a ser concedidos apoios aos agricultores cujas exploraçôes se situassem, ao abrigo das Diretivas Natureza, em zonas designadas como rede Natura 2000, com o objetivo de aplicarem, ou ajustarem, as práticas agrícolas à classificação, contribuindo, desta forma, para a gestão sustentável das áreas da rede. 
Relativo ao apoio ao desenvolvimento rural pelo FEADER, define o contexto estratégico da política de desenvolvimento rural, bem como as prioridades e medidas relativas ao desenvolvimento rural. As medidas do Eixo 2, melhoria Regulamento CE do ambiente e da paisagem rural, conforme definidas no 2005 n. ${ }^{\circ} 1698 / 2005$ do regulamento, eram medidas destinadas, sobretudo, à utilização Conselho de 20 de sustentável das terras agrícolas, através de pagamentos aos Setembro de 2005 agricultores: para a compensação de desvantagens em zonas de montanha; para compensação de desvantagens noutras zonas que não as de montanha; pagamentos Natura 2000; pagamentos agroambientais; e pagamentos relacionados com o bem-estar animal.

Relativo ao apoio ao desenvolvimento rural pelo Fundo Europeu Agrícola de Desenvolvimento Rural (FEADER), revoga o Regulamento (CE) n. ${ }^{\circ}$ 1698/2005 do Conselho. Define os objetivos para os quais a política de desenvolvimento rural deve contribuir e as prioridades específicas da União em matéria de desenvolvimento rural. No que refere os objetivos relacionados com a gestão sustentável dos recursos naturais e açóes no domínio do clima, o regulamento prevê Regulamento UE uma série de medidas, nomeadamente: investimentos não n. ${ }^{\circ} 1305 / 2013$ produtivos ligados ao cumprimento de objetivos no domínio do Parlamento agroambiental e climático, ao nível da conservação da

2013 Europeu e do Conselho de 17 de Dezembro de 2013 biodiversidade das espécies e dos habitats, ou que aumentem o valor de amenidade pública de uma zona Natura 2000, ou de outros sistemas de elevado valor natural (artigo 17. , alínea d); pagamentos ligados ao agroambiente e ao clima (artigo 28. ${ }^{\circ}$ ); pagamentos a favor da agricultura biológica (artigo 29. $)$ ); pagamentos a título da rede Natura 2000 (artigo $30 .^{\circ}$ ); e pagamentos a favor de zonas sujeitas a condicionantes naturais, ou a outras condicionantes específicas (artigos 31. ${ }^{\circ} \mathrm{e}$ 32. ${ }^{\circ}$ ). $\mathrm{O}$ apoio deverá estar associado aos requisitos específicos descritos nos programas de desenvolvimento rural, e deve ultrapassar as normas e os requisitos obrigatórios aplicáveis, de acordo com as regras de ecocondicionalidade.

Fonte: Elaboração própria, a partir das diretivas e regulamentos elencados. 
Foi, no entanto, com o Regulamento CEE n. ${ }^{\circ}$ 2.078/92, que, como já referido, está na base da criação das medidas agroambientais, que a ligação entre a política agrícola e as designadas diretivas "Natureza”, as diretivas "Aves" e "Habitats" passaram a ser evidenciadas de forma mais direta (Lowe e Baldock, 2000), nomeadamente, por meio do alargamento da incidência das medidas agroambientais, de forma a contemplar os requisitos de implementação dessas mesmas diretivas.

As medidas agroambientais são as únicas medidas obrigatórias que os Estados-Membros devem implementar no âmbito da programação rural, pelo que constituem o principal instrumento de política do segundo pilar para incentivar os agricultores a adotarem práticas de gestão agrícola benéficas para a biodiversidade. Uma das virtudes das medidas agroambientais é a sua flexibilidade, a qual permite que os Estados-Membros desenvolvam regimes de ajuda voluntários que reflitam as diferentes condições locais, biofísicas, climáticas, ambientais e agrícolas. Uma série de estudos científicos confirmou que, globalmente, o estado da biodiversidade dos habitats agrícolas sujeitos a medidas agroambientais é significativamente melhor do que seria caso essa política não tivesse sido implementada (Poláková et al., 2011).

A Diretiva "Aves" e a Diretiva "Habitats" constituem o principal quadro jurídico para a conservação da natureza e da biodiversidade na UE. As designadas diretivas "Natureza" contêm uma série de requisitos que, independentemente de serem responsabilidade direta dos Estados-Membros e vinculativos para os agricultores e outros gestores do espaço rural, têm fortes implicaçóes nos espaços rurais.

Aos Estados-Membros são imputadas obrigações, como a implementação de todas as medidas necessárias para preservar, manter ou restabelecer, em termos de diversidade e extensão suficientes, os habitats de todas as espécies de aves que vivem naturalmente em estado selvagem (artigo 3. ${ }^{\circ}$, inciso 1 , da Diretiva "Aves"); de medidas que garantam a manutenção e, se necessário, o restabelecimento dos tipos de habitats naturais e das espécies em estado de conservação favorável (artigo 3..$^{\circ}$, inciso 1, da Diretiva "Habitats"); ou, ainda, a criação de incentivos para a gestão ou desenvolvimento de elementos paisagísticos importantes para a flora e a fauna selvagens, a fim de melhorar a coerência ecológica da rede Natura 2000 (artigos 3. ${ }^{\circ}$, inciso 3 e $10 .^{\circ}$, da Diretiva "Habitats"). 
Os agricultores cujas exploraçóes agrícolas se situem em áreas classificadas como Natura 2000 têm que cumprir certos requisitos, incluídos nas regras de ecocondicionalidade da PAC: a manutenção e adaptação ajustadas aos imperativos ecológicos dos habitats situados no interior e no exterior das ZPE (artigo 3. ${ }^{\circ}$, inciso 2, alínea b, da Diretiva "Aves"); ou a adoção de medidas de conservação especial, respeitantes ao habitat das espécies de aves que vivem naturalmente em estado selvagem, de modo a garantir a sua sobrevivência e reprodução na sua área de distribuição (artigo 4. ${ }^{\circ}$, inciso 1, da Diretiva "Aves"), sob pena de se perder o acesso a pagamentos diretos.

Com a evolução da integração das preocupações ambientais na política agrícola, tornou-se igualmente claro que grande parte da biodiversidade da UE está situada em áreas rurais ou áreas contíguas a exploraçôes agrícolas, e é afetada pelos sistemas de produção e práticas de gestão agrícola. Nesse sentido, foi também reconhecida a importância da implementação e da associação da diretiva "Natureza" à política agroambiental, pois, apesar de não estarem diretamente relacionadas com a agricultura, influenciam a gestão agrícola.

\section{A política agroambiental na União Europeia}

No contexto da PDR, as medidas agroambientais, além de serem assumidas como um instrumento de política que visa à integração da componente ambiental na componente agrícola, constituem, como já referido, as únicas medidas obrigatórias a executar pelos Estados-Membros no âmbito da programação rural.

Às estratégias nacionais de implementação da política agroambiental não são, contudo, alheias questôes históricas e culturais, tais como a importância da agricultura e das questóes agrícolas como referência do mundo rural, bem como o peso que as questóes ambientais ocupam nas sociedades e nos espaços rurais. Se, na UE, a integração da componente ambiental na política agrícola começou a ser colocada com mais acuidade a partir dos anos 1980, no nível nacional, essa preocupação estava já presente em vários Estados-Membros.

De fato, a relevância atribuída aos usos não produtivos das áreas rurais, principalmente no que respeita as suas qualidades estéticas, associadas a uma representação do rural como natureza e paisagem, a chamada tradição naturalista, tem fortes raízes nos países do Norte, sobretudo no Reino Unido, a partir de finais do século XIX (Hoggart et al., 1995). Não é, pois, por acaso 
que o Reino Unido tenha sido o principal arquiteto da política agroambiental europeia. Igualmente, nos países nórdicos, o rural sempre esteve profusamente ligado à natureza, manifestando-se isso na integração da proteção ambiental nas práticas agrícolas e florestais, e no forte caráter regulatório das políticas nacionais no que se refere à conservação da natureza (Hoggart et al., 1995).

Por oposição, nos países do Sul, as atividades não agrícolas só mais recentemente começaram a ser equacionadas. Nesses países, verifica-se uma presença mais frágil das atividades não agrícolas e uma agricultura mais presente, que conforma um rural em acentuada mudança, mas ainda com algumas das suas heranças tradicionais (Baptista, 2001). Daí que, em Espanha, Grécia e Portugal, a introdução da questão ambiental na política agrícola tenha tido início apenas com a aplicação do Regulamento 2.078/92 (Cf. Jollivet, 1997; Guizo, 2011; Mansinho e Schmidt, 1997).

Na mesma perspectiva, a introdução da política ambiental na agenda da UE foi essencialmente da responsabilidade da Alemanha, Dinamarca e Países Baixos, sendo posteriormente reforçada com a adesão da Áustria, Finlândia e Suécia, em 1995 (Rodrigo, 2001). Países estes com fortes tradiçôes nas questóes ambientais e que, em certas áreas, impunham regulamentos mais rígidos, propondo a criação de legislação ambiental para a qual não havia correspondência na União (Johnson e Corcelle, 1997).

A partir do Regulamento 1.257/99, os objetivos das medidas agroambientais não só são redefinidos - a sua acepção passa a ser, exclusivamente, a de um apoio aos métodos de produção agrícola destinados à proteção do ambiente e do espaço natural -, como também progridem, a par e passo, com as regras de ecocondicionalidade estabelecidas para os pagamentos do primeiro pilar. Ou seja, os compromissos agroambientais assumidos passam a ter que ir mais além da mera aplicação das boas práticas agrícolas correntes, e as obrigações legais ambientais passam a ser condição para aceder aos regimes de ajuda, e não meta a atingir. $\mathrm{O}$ alargamento das regras de ecocondicionalidade ao segundo pilar atenuaria, assim, a polarização existente, em termos de regras ambientais, entre as exploraçóes agrícolas apoiadas no âmbito da política agroambiental e as que eram apoiadas no âmbito dos pagamentos diretos (primeiro pilar).

Em 2007, a integração da componente ambiental/conservação da natureza na PDR é consolidada, constituindo uma prioridade estratégica da programação de desenvolvimento rural, por via da política agroambiental. Ou seja, a política agroambiental passa de medida de acompanhamento da reforma da 
PAC, com um peso bastante reduzido no orçamento do FEOGA-Garantia, a uma das medidas centrais de desenvolvimento rural, não só em termos de programação mas também em termos de financiamento - em 1998, a política agroambiental representava $4 \%$ do orçamento total do FEOGA-Garantia; em 2012, os pagamentos agroambientais representavam 53\% da despesa realizada do FEADER (Clemente, 2016)..$^{55}$

Os pagamentos agroambientais, juntamente com os pagamentos Natura 2000, constituíam as principais medidas para a integração dos objetivos ambientais/conservação da natureza no desenvolvimento rural, e para a operacionalização dos compromissos assumidos pela UE no âmbito da biodiversidade.

Em dezembro de 2013, e tendo por base a distribuição percentual da despesa pública total programada para o período 2007-2013, os pagamentos agroambientais constituíam prioridade orçamental na maioria dos Estados-Membros, com maior peso na Bélgica, Suécia, Países Baixos, Reino Unido e Hungria (despesa pública superior a 65\%). A exceção foram França e Portugal, cuja prioridade incidiu nos pagamentos para compensação de desvantagens em zona de montanha (despesa pública superior a 30\%); e Malta, Letônia, Lituânia e Polônia, com primazia nos pagamentos para compensação de desvantagens em zonas que não as de montanha (despesa pública superior a 40\%). Relativamente aos pagamentos Natura 2000 (setor agrícola), poucos foram os países que incluíram essa medida na sua programação (apenas doze), e os que o fizeram atribuíram-lhe um orçamento muito reduzido - Bulgária, Hungria, Irlanda e Letônia foram os países com maior peso de despesa pública total programada para os pagamentos Natura 2000 (entre 2\% e 6\%). ${ }^{6}$

No final de 2013, a proporção de área agrícola apoiada por pagamentos agroambientais, ao abrigo dos programas de desenvolvimento rural, representava 26,3\% da SAU na UE27 (excluída a Croácia). Em cinco Estados-Membros, esses pagamentos representavam mais de 50\% da SAU apoiada por medidas de desenvolvimento rural - Finlândia (93,7\%), Luxemburgo (90,3\%), Áustria (76,9\%), Suécia $(62,4 \%)$ e Estônia (56,9\%); por oposição, a

\footnotetext{
5 Entende-se por política agroambiental a integração de preocupaçôes ambientais na política agrícola com os objetivos de minimizar os riscos de degradação ambiental e de aumentar a sustentabilidade dos ecossistemas agrícolas.

6 Para um maior aprofundamento da análise da aplicação da Política Agroambiental na UE, no período 2007-2013, ver Clemente, 2016.
} 
Dinamarca (6,5\%), o Chipre $(8,8 \%)$ e a Grécia $(1,8 \%)$ tinham menos de $10 \%$ de área apoiada por esse tipo de medida. No total da UE27, o Reino Unido contribuía com a maior proporção de SAU apoiada por medidas agroambientais, representando $15 \%$ da SAU da UE apoiada por esse tipo medida, logo seguido pela França (14\%), Espanha (12\%) e Alemanha (11\%).

No atual quadro de programação comunitária (2014-2020), a UE entende que os objetivos de desenvolvimento rural serão realizados por meio de seis prioridades estratégicas, constituindo a prioridade 4: "Restaurar, preservar e melhorar os ecossistemas ligados à agricultura e à silvicultura”, a mais relevante no contexto da rede Natura 2000.

Tabela 3 - Prioridades estratégicas de desenvolvimento rural 2014-2020

P1: Fomentar a transferência de conhecimentos e a inovação nos setores agrícola e florestal e nas zonas rurais. $(*)$

P2: Aumentar a competitividade e a viabilidade das exploraçóes agrícolas, todos os tipos de agricultura, em todas as regióes, e promover tecnologias agrícolas inovadoras e a gestão sustentável das florestas.

P3: Promover a organização da cadeia alimentar, incluindo a transformação e comercialização dos produtos agrícolas, o bem-estar animal e a gestáo de riscos na agricultura.

P4: Restaurar, preservar e melhorar os ecossistemas dependentes da agricultura e das florestas.

P5: Promover a utilização eficiente dos recursos e apoiar a passagem para uma economia hipocarbónica e resiliente às alterações climáticas nos setores agrícola, alimentar e florestal.

P6: Promover a inclusão social, a redução da pobreza e o desenvolvimento económico das zonas rurais.

Fonte: Artigo $5^{\circ}$ do Regulamento da EU no 1305/2013 do Parlamento Europeu e do Conselho de 17 de Dezembro de 2013.

Notas: $\left(^{*}\right)$ A P1 é uma prioridade transversal a toda a programação rural 2014-2020.

Entre as medidas que a UE considera de particular interesse para o cumprimento da prioridade 4 estáo o agroambiente e clima (M10), a agricultura biológica (M11), os pagamentos a título da rede Natura 2000 (M12) e os 
pagamentos relativos a zonas sujeitas a condicionantes naturais ou outras condicionantes específicas (M13). A UE considera que as medidas agroambientais, agora incorporadas às medidas climáticas, deverão continuar a desempenhar um papel importante no apoio ao desenvolvimento sustentável das zonais rurais, e na resposta à procura crescente de serviços ambientais por parte da sociedade, pelo que a sua inclusão nos programas de desenvolvimento rural dos Estados-Membros é obrigatória. À semelhança do período 2007-2013, continua a ser a única medida imposta no âmbito da programação rural dos Estados-Membros.

Em finais de 2016, a P4 era a prioridade com maior peso na despesa pública total programada da UE28 (45,8\%), sendo superior a $60 \%$, na Irlanda (73\%), Finlândia (70\%), Reino Unido (69\%), Áustria (68\%), Dinamarca (67\%), República Checa (65\%) e Suécia (63\%). Apenas Portugal apresentava uma despesa pública programada na P4 abaixo dos 30\% (29\%).

Nesse mesmo período, na UE28, as medidas com maior peso na programação da P4 eram por ordem de importância, a M13 e a M10 (respetivamente, com 36\% e 35\% de dotação programada). Finlândia (65\%), França (63\%), Eslováquia (54\%) e Polônia (52\%) apresentavam uma despesa pública programada superior a 50\% na M13, e, em contraste, o Reino Unido (7\%) e a Hungria $(6 \%)$ apresentavam dotaçóes abaixo dos $10 \%$ nessa medida. A M10, única medida obrigatória, foi programada por todos os países e constituiu prioridade orçamental, na maioria dos Estados-Membros, com dotação acima dos 50\%, no Reino Unido (71\%), na Estônia (67\%), na Bélgica (55\%), nos Países-Baixos (54\%) e na Hungria (53\%). Apenas Malta apresentava uma dotação abaixo dos $15 \%$ (13\%). No que se refere à M12, e por comparação com 2007-2013, mais Estados-Membros programaram despesa pública para essa medida. Contudo, apenas quatro países apresentavam valores acima dos $6 \%$, nomeadamente Bulgária (14\%), Hungria (14\%), Estônia (9\%) e Bélgica (7\%).

Apesar dos pagamentos agroambientais e climáticos constituírem a única medida obrigatória dos programas de desenvolvimento rural, isso não significa que a esta seja considerada prioritária na programação dos Estados-Membros - em doze Estados-Membros (de forma mais ou menos equilibrada), a prioridade orçamental atribuída à M13 revelou-se mais relevante do que a M10. Isso significa que há um forte sistema concorrencial (quer no nível do segundo pilar, quer entre pilares) e que, muitas vezes, acabam por prevalecer regimes de ajuda que estão mais relacionados com a prática agrícola do que com as 
práticas ambientais, por serem mais competitivos em termos de montantes e taxas de apoio. Se as medidas agroambientais são obrigatórias para os Estados-Membros, são voluntárias para os agricultores, pelo que "ganham" as medidas mais apelativas, quer em termos de financiamento, quer em termos de gestão da prática agrícola. Ou seja, os agricultores tenderão a optar por regimes de ajuda que apoiem métodos já usados e não impliquem uma transformação das suas práticas agrícolas.

Tal como a implementação da política agroambiental varia de forma distinta entre Estados-Membros, também as metas a atingir são diferentes. $\mathrm{Na}$ programação de 2014-2020, essas metas refletem não só os períodos de programação anterior, como também as circunstâncias nacionais e as diferentes prioridades estratégicas definidas por cada Estado-Membro. Nesse sentido, e no conjunto da UE28, estima-se que $22,5 \%$ da SAU seja apoiada por medidas agroambientais em 2020: 99,9\% na Finlândia; 93,5\% em Luxemburgo; 81,3\% na Áustria; e 80,3\% na Eslovênia. Na Lituânia (9,5\%), Croácia (6,4\%), Países Baixos (6,1\%), Malta (6,0\%) e Bulgária (3,2\%), estima-se que a SAU em medidas agroambientais seja inferior a $10 \%$. Estima-se igualmente que, em 2020, o país com maior peso de área agrícola apoiada por pagamentos agroambientais e climáticos na UE28 seja Espanha (13\%), ultrapassando o Reino Unido (12\%), a Alemanha, a França e a Itália (cada com 9\%).

\section{... E a sua implementação em Portugal}

Em Portugal, como se referiu anteriormente, a integração de objetivos ambientais na política agrícola deu-se apenas com a transposição do Regulamento 2.078/92 para o direito interno. A relativa debilidade do debate nacional sobre os problemas agroambientais deriva, em parte, da perspetiva que vê a modernização da agricultura como um processo inacabado (Lowe et al., 2000; Guizo, 2011) e reflete a herança do país ter vivido um longo período de tempo sob um regime político autoritário que sobrevalorizava a agricultura e o mundo rural (Hoggat et al., 1995). Consequentemente, a revolução de 1974 conduziu a uma concepção de desenvolvimento que colocava o setor primário no último lugar dos setores econômicos e considerava a "desruralização" do país um objetivo a atingir, por oposição ao regime e ideologia salazaristas (Mansinho e Schmidt, 1997). 
Paralelamente, e tal como o processo de reforma agrária veio a demonstrar, os direitos de propriedade estáo profundamente enraizados no mundo rural, mesmo se de modo desigual a norte e a sul do país, pelo que Portugal tem tentado evitar abordagens regulatórias que possam ser consideradas uma interferência nos direitos de propriedade dos agricultores. Dessa posição política resultaram retrocessos na implementação da política agroambiental. Os regimes de apoio agroambientais têm sido entendidos como fonte de rendimento complementar para os agricultores, servindo, em certos casos, para financiar as estruturas das exploraçóes agrícolas - medidas que pouco têm a ver com questôes ambientais -, ou constituindo um regime de apoio aos agricultores familiares tradicionais, principalmente nas regiôes mais deprimidas do país (cf. Lowe et al., 2000).

O primeiro programa agroambiental português, aprovado em 1994, contemplava, na sua maioria, medidas horizontais aplicáveis a todo o território, ou a regióes definidas, e procurava dar resposta a problemas concretos da agricultura de cada região, e apoiar os sistemas tradicionais extensivos, que correspondiam a paisagens específicas (Pinto-Correia, 2001). O programa incidia nas regióes mais desfavorecidas, regióes com fragilidades estruturais e caraterizadas por uma acentuada recessão demográfica, baixo nível de qualificação das populaçóes e acentuado envelhecimento (Cordovil e Rosa, 1997).

Em 2001, enquadrado pelo Regulamento 1.257/99, foi aprovado o segundo Programa Agroambiental nacional. Integrado no Plano de Desenvolvimento Rural, RURIS, o segundo programa agroambiental mantinha uma continuidade em termos de objetivos, apresentando, no entanto, algumas variaçôes em relação ao primeiro, nomeadamente, no nível da estrutura, com o alargamento das áreas de intervenção.

Durante esses dois períodos de programação, o país optou, todavia, pela implementação de programas nacionais que, pese embora algumas medidas incidissem em determinadas regiões com problemas agrícolas particulares, na sua maioria consistiam em medidas horizontais. A única medida de cariz territorial foi o Plano Zonal de Castro Verde (PZCV), aplicado entre 1995 e 2005, que se destinava a uma zona ambientalmente sensível e refletia uma situação ambiental e condiçóes naturais próprias, e para a qual foram traçados apoios e compromissos que tinham em conta as estruturas agrícolas e as principais orientaçôes da produção agrícola. 
Mais recentemente, dados relativos à despesa pública programada do Programa de Desenvolvimento Rural em Portugal (PRODER), para o período 2007-2013, revelam que a prioridade orçamental foi dada a medidas relacionadas com a promoção da competitividade agrícola $(41,9 \%)$, em detrimento de medidas com impacto na gestão sustentável do espaço rural $(33,4 \%)$. Apesar de estas últimas representarem cerca de $33 \%$ da dotação total da programação rural, a prioridade recaiu em medidas relacionadas com a produção agrícola, nomeadamente, com a manutenção da atividade agrícola em áreas desfavorecidas, e com a valorização de modos de produção, mantendo-se a agricultura como o domínio central da programação de desenvolvimento rural em 2007-2013.

Tendo em conta o aumento, ao longo dos $\operatorname{anos}^{7}$, da proporção de área agrícola apoiada por regimes de ajuda agroambiental, em 2009, de acordo com o EUROSTAT, mais de $45 \%$ da área agrícola sob compromisso em Portugal estava incluída na categoria "produção integrada”, que constitui um sistema agrícola de produção de produtos agrícolas, assentes em boas práticas agrícolas e ambientais.

De fato, em Portugal, a agricultura ainda tem um peso relevante, não só do ponto de vista econômico, social e simbólico, mas também do ponto de vista ambiental e territorial. As áreas rurais representam cerca de $81 \%$ do território nacional continental, $18 \%$ da SAU estando integrada em áreas rede Natura $2000^{8}$, as quais abrangem $15 \%$ da superfície agrícola do continente. Simultaneamente, em $90 \%$ da superfície total da Natura 2000, existe um elevado grau de associação entre os valores naturais a conservar e o tipo de gestão agrícola e florestal praticada (Santos et al., 2006), remetendo para a ideia de que, tal como no resto da Europa, também em Portugal grande parte da biodiversidade está situada em áreas rurais ou áreas contíguas a exploraçóes agrícolas e é afetada pelos sistemas de produção e práticas de gestão agrícola.

Apesar de Portugal estar entre os países da UE com maior proporção do seu território abrangido pela rede Natura 2000 e maior proporção de SAU, quer em rede Natura, quer em sistemas agrícolas de alto valor natural,

\footnotetext{
7 Em 2001, a área agrícola apoiada por medidas agroambientais correspondia a 12,2\% da SAU do país, em 2007, a 27,5\% e, em 2013, a 29,4\%. A meta de Portugal para 2020 é a de que a proporção de SAU sob compromisso agroambiental seja de 31\%.

8 Em Portugal, a rede Natura 2000 é composta por 166 áreas classificadas, que representam cerca de $21 \%$ da superfície terrestre do país (valores em março de 2019).
} 
a estratégia política nacional tem-se escorado em medidas relacionadas com o aumento da competitividade da agricultura. Isso acontece porque a multifuncionalidade das áreas rurais portuguesas não se concretizou plenamente.

\section{Portugal "Um rural que já não é agricultura, mas que ainda não é outra coisa”}

A evolução das políticas para o desenvolvimento dos espaços rurais em Portugal não é dissociável da evolução da política europeia de desenvolvimento rural. À semelhança do que aconteceu na maioria dos países europeus, também em Portugal, os anos 1950 constituíram um período em que as políticas públicas para as áreas rurais foram orientadas para a modernização da agricultura, com vista ao aumento da produção e produtividade agrícolas.

A partir dos anos 1960, e até ao início dos anos 1990, não obstante a perda de importância da agricultura como atividade econômica dominante nos espaços rurais, a aposta da UE continuou a recair na produção e na modernização agrícolas. Essa opção escudava-se nos próprios objetivos da PAC, consagrados no Tratado de Roma, de aumentar a produtividade da agricultura, promovendo o progresso técnico e assegurando o desenvolvimento racional da produção agrícola e a ótima utilização dos fatores de produção.

Portugal não fugiu a esse modelo, e, desde a sua adesão à UE, em 1986, e até 1992, ano em que se deu a primeira grande reforma da PAC e teve início o Programa Ligação Entre Ações de Desenvolvimento da Economia Rural (Programa LEADER ${ }^{9}$ ), as preocupaçóes da política rural situaram-se, quase

\footnotetext{
9 A ideia base do LEADER era a criação de um programa que perfilhasse os princípios do desenvolvimento local (parcerias, descentralização, territorialização, inovação etc.), com o objetivo de combater a desertificação das zonas rurais, criando condiçóes para a sua revitalização endógena. O LEADER I (1991-1994) tinha por objetivo principal a experimentação de novas abordagens locais, inovadoras e demonstrativas, baseando-se numa concepçáo integrada e endógena do desenvolvimento das áreas rurais (Comunicaçáo aos Estados-Membros 91/C 73/14, publicada no JO C 73, de 19 de março de 1991, p. 33-7).

O LEADER II (1994-1999), delineado no âmbito da segunda reforma dos fundos estruturais (de 1993), manteve o essencial do seu antecessor. Contudo, nessa iniciativa, a inovação desempenhou um papel importante tanto no nível do método e do conteúdo das açóes como por meio da articulação com as políticas em curso no mesmo território (Comunicação aos Estados-Membros 94/C 180/12, publicada no JO C 180, de 1 de julho de 1994, p. 48-59).

O objetivo do LEADER+ (2000-2006) era o de incentivar os agentes rurais a refletirem sobre o potencial de desenvolvimento dos territórios numa perspetiva a mais longo prazo. Articulava-se em torno de três vetores: vetor 1 - apoio a estratégias territoriais de desenvolvimento rural, integradas e de carácter piloto, assentes na abordagem ascendente e na parceria horizontal; vetor
} 
exclusivamente, no âmbito dos investimentos estruturais (modernização das exploraçóes agrícolas, melhoria da transformação e da comercialização dos produtos agrícolas e rejuvenescimento da agricultura). É, contudo, possível identificar algumas medidas surgidas no âmbito da política regional, com o objetivo de corrigir as assimetrias regionais, que incidiram no desenvolvimento de espaços rurais com problemas de desenvolvimento específicos. As primeiras medidas de desenvolvimento rural surgem em meados dos anos 1980, no âmbito da política regional, com a aprovação do Projeto de Desenvolvimento Rural Integrado de Trás-os-Montes (PDRITM), em 1982, e de vários Programas Integrados de Desenvolvimento Regional (PIDR) postos em prática, entre 1985 e 1986, em diferentes regiōes do país (Cova da Beira, Baixo Mondego, Norte Alentejo etc.).

As duas grandes reformas dos fundos estruturais da UE conduziram a fortes transformaçóes das áreas rurais da Europa, resultantes da alocação de fundos estruturais para apoiar programas de desenvolvimento integrado em áreas rurais ${ }^{10}$. Com a reforma dos fundos estruturais, a UE adota uma metodologia de orientação dos fundos estruturais para objetivos prioritários, assente numa visão territorial e intersetorial do desenvolvimento, e acordada nos seguintes princípios: concentração, programação, parceria e adicionalidade. Durante esse período (1989-1999), todas as regióes de Portugal foram elegíveis no âmbito do Objetivo 1, ou Objetivo da Convergência, que se concentrava nas regióes menos desenvolvidas da UE (regióes com um PIB per capita inferior a 75\% da média europeia). Contudo, as intervençóes no âmbito da política agrícola em Portugal abrangeram, sobretudo, ações de melhoria das condições de produção agrícola e de eficácia das exploraçóes agrícolas, valorização da qualidade dos produtos, desenvolvimento dos recursos humanos em meio rural e, em menor escala, medidas relacionadas com a preservação do ambiente e dos recursos naturais, por força da obrigatoriedade das medidas agroambientais.

2 - apoio à cooperação interterritorial e transnacional; vetor 3 - colocaçáo em rede do conjunto dos territórios rurais da União, beneficiários ou não do LEADER+, bem como de todos os agentes de desenvolvimento rural (Comunicaçáo da Comissão aos Estados-Membros 2.000/C 139/05, publicada no JO C 139, de 18 de maio de 2000, p. 5-13).

${ }^{10}$ Com essa reforma, pela primeira vez foram estabelecidos objetivos prioritários para a aplicação dos fundos estruturais, que determinaram a passagem definitiva de uma abordagem setorial para a programação integrada de medidas que podiam abranger os três grandes fundos estruturais europeus (FEDER, FSE e FEOGA-Orientação), por meio do desenvolvimento de projetos orientados e coordenados em nível regional. 
Em suma, as políticas nacionais traçadas visavam, maioritariamente, ao reforço da competitividade do setor agrícola e à promoçáo da viabilidade econômica das exploraçôes agrícolas. À exceção do Programa LEADER, o apoio estrutural ao desenvolvimento rural aconteceu, durante esse período, quase sempre no âmbito da Política de Coesão (por intermédio dos Programas Operacionais regionais).

Entre 2000 e 2006, período que abrange a constituição oficial da PDR como segundo pilar da PAC, a multifuncionalidade da agricultura e a abordagem multissetorial, a eficácia e a transparência na elaboraçáo e na gestáo dos programas definem-se como princípios fundamentais dessa política. A PDR emerge, assim, como segundo pilar da PAC, no sentido de um desenvolvimento sustentável que assegurasse maior coerência entre o desenvolvimento rural e a política de preços e mercados da PAC, promovendo todas as suas componentes e incentivando a participação dos agentes locais. Tratar-se-ia de uma política de desenvolvimento rural ligada às atividades agrícolas e à sua reconversão, com vista ao melhoramento das exploraçôes agrícolas; à segurança e à qualidade dos produtos alimentares; à promoção de rendimentos equitativos e estáveis para os agricultores; à tomada de consciência dos desafios ambientais; à promoçáo de atividades complementares ou alternativas, criadoras de emprego, que travassem o êxodo rural e reforçassem o tecido econômico e social dos espaços rurais; e ao melhoramento das condiçóes de vida e de trabalho e à igualdade de oportunidades.

Nesse âmbito, a UE aprova um regulamento referente ao apoio do Fundo Europeu de Orientação e Garantia Agrícola (FEOGA ${ }^{11}$ ) ao desenvolvimento rural, o Regulamento CE n.o 1.257/99, que junta, num único regulamento, nove regulamentos anteriormente em vigor - i) investimentos nas exploraçôes agrícolas; ii) instalação de jovens agricultores; iii) formação; iv) reforma antecipada; v) zonas desfavorecidas e regióes com condicionantes ambientais; vi) medidas agroambientais; vii) melhoria da transformação e da comercialização de produtos agrícolas; viii) silvicultura; ix) promoção da

\footnotetext{
${ }^{11}$ Criado em 1958, o FEOGA sofre a sua primeira grande transformação em 1964, sendo dividido em duas seçóes: a Seçáo Garantia, com o objetivo de financiar a componente de preços e mercados agrícolas e assegurar aos agricultores a equidade de rendimentos; e a Seção Orientação, com a finalidade de cofinanciar projetos de reconversão e de criação de estruturas agrícolas, contemplando, assim, a componente sócio-estrutural, e que, em 1999, viria a tornar-se o segundo pilar da PAC.
} 
adaptação e do desenvolvimento das zonas rurais -, com o objetivo de cofinanciar o segundo pilar.

Apesar do novo regulamento ter como objetivo a integração e a coerência global da PDR, o seu impacto foi minimizado, nomeadamente pelo fato de algumas medidas serem financiadas pela seção Garantia, outras pela seção Orientação do FEOGA e, ainda, em alguns Estados-Membros, pela complicação adicional de algumas medidas serem financiadas por seçóes diferentes consoante o tipo de regiáo-objetivo.

Em Portugal, isso significou uma fragmentação das medidas de desenvolvimento rural por quatro programas: o Programa Operacional de Agricultura e Desenvolvimento Rural (Programa AGRO) e a Medida Agricultura e Desenvolvimento Rural (Medida AGRIS) dos Programas Operacionais Regionais, ambos no âmbito dos Programas Operacionais do terceiro Quadro Comunitário de Apoio (QCAIII); o Plano de Desenvolvimento Rural, ou RURIS, que integrava as medidas de acompanhamento da PAC, financiadas pelo FEOGA - Seção Garantia; e o LEADER+, exclusivamente financiado pela seção orientação do mesmo fundo.

Noutros termos, em Portugal, e à semelhança de Espanha, da Irlanda e da Grécia, países em que as áreas rurais constituíam, na sua totalidade, regióes Objetivo 1, os planos de desenvolvimento rural apenas contemplavam as medidas de acompanhamento da PAC, nomeadamente: medidas agroambientais, florestação de terras agrícolas, reforma antecipada, e indenizações compensatórias (também designadas, regime de apoio para as zonas desfavorecidas e regiôes com condicionantes ambientais). As outras medidas de desenvolvimento rural estavam incluídas nos Programas Operacionais referentes ao Objetivo 1 (Bandarra, 2001). As medidas estruturais de apoio ao desenvolvimento rural eram objeto de programação integrada, no âmbito dos Programas Operacionais do QCAIII (AGRO e Medida AGRIS) e do Programa LEADER.

Em 2005, tendo em vista quer o estabelecimento de um quadro legal único para o financiamento das despesas decorrentes da PAC, quer a canalização de mais financiamento para a PDR, no período financeiro de 2007 2013, foram instituídos dois novos fundos comunitários que revogaram o FEOGA nas suas duas seçóes: o Fundo Europeu Agrícola de Garantia (FEAGA) e o Fundo Europeu Agrícola de Desenvolvimento Rural (FEADER). $\mathrm{O}$ primeiro suportaria as açóes destinadas à regularização dos mercados agrícolas e os pagamentos diretos aos agricultores previstos no âmbito 
da PAC. O segundo cofinanciaria os programas de desenvolvimento rural, concentrando, desse modo, toda a componente estrutural da PAC.

Essa inflexão não significou, no entanto, no país, mais do que continuidade no financiamento de medidas relacionadas com aumento da competitividade do setor agrícola. Concretamente, a partir de 2007, as medidas de desenvolvimento rural passaram a fazer parte de uma programaçáo única, o Programa de Desenvolvimento Rural (PRODER), o instrumento programático e financeiro de aplicaçáo da PDR em Portugal Continental, para o período 2007-2013, financiado exclusivamente pelo FEADER. Em finais de 2015, e após o encerramento da execução do PRODER 2007-2013, o montante total dos pagamentos efetuados era de cerca de $4.3 \mathrm{mil}$ milhôes de euros de despesa pública e de 3.5 mil milhôes de euros de comparticipação FEADER - representando as medidas relacionadas com a competitividade do setor agrícola 43\% do total executado (Domingos et al., 2016).

Se, até a adesão de Portugal à UE, a inexistência de políticas de desenvolvimento rural integrado constituía um dado adquirido, ainda hoje não se pode falar de uma política de desenvolvimento rural, dada a ausência de articulação entre os vários instrumentos e, essencialmente, dada a concentração das preocupaçóes com o setor agrícola (Figueiredo, 2003).

Em Portugal, “o rural já está depois da agricultura mas ainda não é outra coisa, ou melhor, outras coisas" (Baptista, 2006, p. 100). Ou seja, a transição rural é ainda muito incipiente. Se, por um lado, os desafios que se colocam atualmente ao desenvolvimento rural não se esgotam na dimensão agrícola e convocam novas articulaçôes entre o rural e o agrícola, por outro lado, as questóes relacionadas com a agricultura estão sempre, direta ou indiretamente, presentes nas propostas que se têm avançado para o desenvolvimento em meio rural.

Parece, todavia, claro que as orientaçóes estratégicas da política nacional de desenvolvimento rural e o padrão de programação a favor de medidas relacionadas com a modernização das estruturas agrícolas, isto é, de medidas que promovem o aumento da competitividade da agricultura, não têm resultado, como se verá de seguida, do ponto de vista do desenvolvimento e da coesão das áreas rurais portuguesas. 


\section{O retrato territorial de Portugal}

Portugal ainda é um país com uma forte componente rural. As Áreas Predominantemente Rurais (APR) ${ }^{12}$ representam 79,0\% do território nacional por oposição às Áreas Predominantemente Urbanas (APU), que representam 6,4\% (EC, 2018). Das 25 regiôes NUTS III, 16 são APR, de baixa densidade, remotas e em contração econômica - no período entre 2013 e 2015, as APR portuguesas registavam um PIB per capita de 64,7\%, e as APU registavam um PIB de 90,4\% (72\% representando o valor médio nacional).

Apesar do investimento realizado na modernização das estruturas agrícolas, em 2017, o índice parcial de competitividade ${ }^{13}$ era inferior a 100 (média nacional) em todas as regiōes predominantemente rurais ${ }^{14}$, com exceção do Alentejo Litoral. No que concerne ao índice parcial de coesão ${ }^{15}$, apenas quatro das dezesseis regióes predominantemente rurais apresentavam valores acima da média nacional (Alto Minho, Região de Coimbra, Região de Leiria e Alentejo Central). Quanto ao índice parcial de qualidade ambiental ${ }^{16}$, em nove regiôes

${ }^{12}$ Segundo o Instituto Nacional de Estatística de Portugal, define-se como:

- Área Predominantemente Urbana (APU) - Freguesia que contempla, entre outros, o seguinte requisito: a freguesia integra a sede da Câmara Municipal e tem uma população residente superior a 5.000 habitantes.

- Área Mediamente Urbana (AMU) - Freguesia que contempla, pelo menos, entre outros, o seguinte requisito: a freguesia integra total ou parcialmente um lugar com população residente igual ou superior a 2.000 habitantes e inferior a 5.000 habitantes, sendo que o peso da população do lugar no total da populaçáo residente na freguesia ou no total da população residente no lugar é igual ou superior a $50 \%$.

- Área Predominantemente Rural (APR) - Freguesia não classificada como "Área Predominantemente Urbana” nem "Área Mediamente Urbana”.

13 "O índice de competitividade pretende captar o potencial (em termos de recursos humanos e de infraestruturas físicas) de cada região em termos de competitividade, assim como o grau de eficiência na trajetória seguida (medido pelos perfis educacional, profissional, empresarial e produtivo) e, ainda, a eficácia na criação de riqueza e na capacidade demonstrada pelo tecido empresarial para competir no contexto internacional" (INE).

${ }^{14}$ Constituem regióes predominantemente rurais: Alto Minho, Alto Tâmega, Douro, Terras de Trás-os-Montes, Oeste, Região de Coimbra, Região de Leiria, Viseu Dão Lafôes, Beira Baixa, Médio Tejo, Beiras e Serra da Estrela, Alentejo Litoral, Baixo Alentejo, Lezíria do Tejo, Alto Alentejo e Alentejo Central.

15 "O índice de coesão procura refletir o acesso potencial da população a equipamentos e serviços coletivos básicos (saúde, educação, cultura), bem como perfis associados a uma maior inclusão social e a eficácia das políticas públicas traduzida no aumento da qualidade de vida e na reduçáo das disparidades territoriais" (INE).

16 "A qualidade ambiental está associada às pressóes exercidas sobre o meio ambiente e o território, mas também aos respectivos efeitos sobre o estado ambiental (qualidade da água, do ar e 
predominantemente rurais, os valores posicionavam-nas acima da média nacional. Apesar dessa variação, em nenhuma dessas regióes, o índice sintético de desenvolvimento regional ${ }^{17}$ estava acima da média nacional (mapa 1).

Mapa 1 - Índice sintético de desenvolvimento regional e índices parciais de competitividade, de coesão e de qualidade ambiental: situação face à média nacional (Portugal $=100$ ), NUTS III, 2017

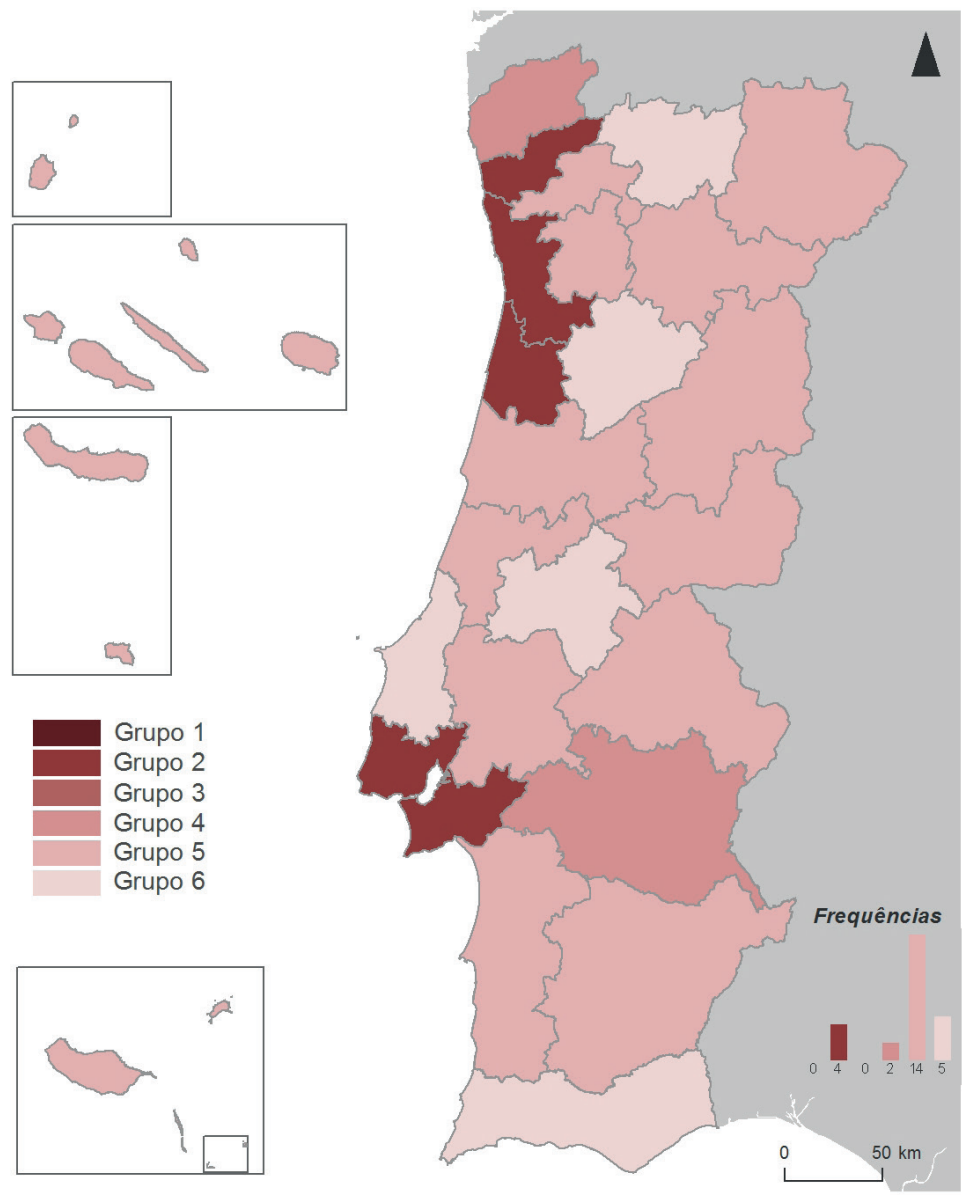

Fonte: INE, I.P.,Índice sintético de desenvolvimento regional.

utilização eficiente da energia) e às respostas em termos de comportamentos individuais e de implementação de políticas públicas" (INE).

17 "O Índice Sintético de Desenvolvimento Regional (ISDR) baseia-se num modelo conceitual que privilegia uma visão multidimensional do desenvolvimento regional, estruturando-o em três componentes: competitividade, coesão e qualidade ambiental” (INE). 


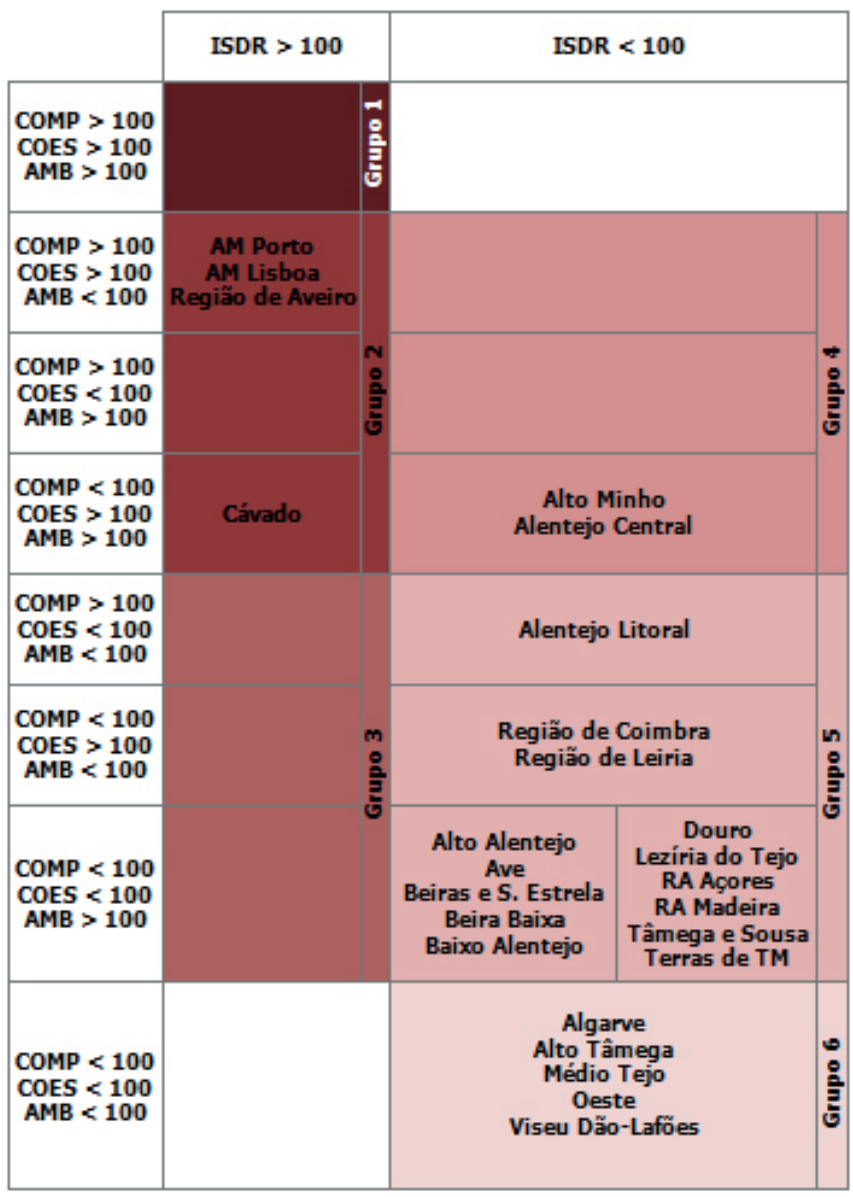

Dessa análise, ressalta que, pese embora o investimento realizado, no retrato territorial nacional, as áreas rurais continuam a ser pouco competitivas e coesas; em contrapartida, apresentam uma qualidade ambiental acima da média nacional. Após cerca de 30 anos de investimento, as regióes rurais não conseguiram reduzir as suas assimetrias e convergir com os valores nacionais de desenvolvimento. $\mathrm{O}$ que significa que os investimentos feitos em benefício das áreas rurais talvez não tenham sido, e náo estejam a ser, os mais indicados. 


\section{Considerações Finais}

Em 1988, o relatório da UE, O futuro do mundo rural, tipificava os espaços rurais europeus de acordo com os problemas de desenvolvimento que enfrentavam. As regiões rurais portuguesas enquadravam-se no segundo problema-tipo, o declínio rural. Eram regiões caracterizadas por um forte êxodo rural, em que o peso da agricultura era ainda relativamente significativo. A persistência de explorações agrícolas de pequena dimensão estava na base de situações de subemprego, com o abandono progressivo dos campos por parte da população ativa e o agravamento de fenômenos de erosão. Para cada problema-tipo, a UE distinguia uma estratégia de base que, no caso das regiões em acentuado declínio, preconizava passar pelo desenvolvimento e diversificação da sua base econômica. Isso não significava, contudo, que a agricultura e a silvicultura não fizessem parte da solução, antes sugeria que, sem agricultura, não poderia haver desenvolvimento rural (CCE, 1988).

Quase três décadas depois, as áreas rurais portuguesas continuam a ser alvo de declínio e abandono agrícola. Esse processo teve início a partir dos anos 1960, sucessivos quadros comunitários, tendo-se revelado incapazes de o reverter, ou mesmo travar. As áreas rurais nacionais continuam a ser pouco competitivas e coesas; não conseguiram reduzir as suas assimetrias e convergir com os valores nacionais de desenvolvimento. Em contrapartida, apresentam uma qualidade ambiental acima da média, o que pode ser entendido como uma vantagem comparativa do seu desenvolvimento, no quadro de estratégias de política que se apoiam na qualidade ambiental desses espaços.

Apesar da regressão da agricultura como atividade principal e do crescimento do plurirrendimento e da pluriatividade agrícolas terem alterado o funcionamento econômico das áreas rurais portuguesas, a redefinição "compulsiva" do espaço rural português está ainda associada em excesso à modernização e ao aumento da produção e produtividade agrícolas. Igualmente, a integração do ambiente, na sua componente de conservação da natureza nos programas de desenvolvimento rural em Portugal, está praticamente confinada aos compromissos assumidos pelo país no âmbito das políticas de desenvolvimento rural e de ambiente da UE, não sendo assumida como estratégia de desenvolvimento para as áreas rurais.

Em suma, nas estratégias de desenvolvimento rural de tipo agroambiental, o ambiente não é considerado uma vantagem comparativa nos instrumen- 
tos e mecanismos delineados para as áreas rurais, sendo a prioridade orçamental e a alocação de recursos orientadas para a produção agrícola.

\section{Referências}

ARNALTE, Eladio et al. El desarrollo rural:politicas aplicadas, situación actual del debate y perspectivas del futuro a nivel europeo. Documento de trabajo. Bruxelas: Parlamento Europeu, 1998. (Serie Agricultura, Montes y Desarrollo Rural, AGRI-106).

BAPTISTA, Fernando Oliveira. Agriculturas e territórios. 1. ed. Oeiras: Celta Editora, 2001.

. "O rural depois da agricultura". In FONSECA, Maria Lucinda (coord.), Desenvolvimento e território: espaços rurais pós-agricolas e novos lugares de turismo e lazer: Homenagem à Professora Doutora Carminda Cavaco. Lisboa: Centro de Estudos Geográficos, 2006, p. 85-105.

CAPUCHA, Luís. "Fazer render o belo: questões à volta do turismo e do desenvolvimento em zonas rurais recuadas”. Sociologia, Problemas e Práticas, n. 21, p. 29-46, maio 1996.

CLEMENTE, Susana. Políticas de desenvolvimento em áreas rurais classificadas: o caso português (tese). Universidade de Lisboa, 2016.

COMISSÃO DAS COMUNIDADES EUROPEIAS (CCE). O futuro do mundo rural. Luxemburgo: Serviço das Publicações Oficiais das Comunidades Europeias, 1988, v. 1.

CORDOVIL, Francisco e ROSA, Manuel. Desenvolvimento rural: novas realidades e perspectivas. Lisboa: Direcção-Geral de Desenvolvimento Rural, 1997.

COVAS, António. Ajustamento, diversificação e desenvolvimento rural. Lisboa: Direcção-Geral de Desenvolvimento Rural, 1997.

DAX, Thomas e KAHILA, Petri. "Policy perspective: the evolution of EU Rural Policy". In COPUS, Andrew e HÖRNSTRÖM, Lisa (eds.). The new rural Europe: towards Rural Cohesion Policy. Estocolmo: Nordregio, 2011, p. 87-106.

EUROPEAN COMMISSION (EC). CAP context indicators 2014-2020: 2018 update. Luxemburg: Publications Office of the European Union, 2018.

EUROPEAN ENVIRONMENT AGENCY (EEA). 10 messages for 2010: agricultural ecosystems. Luxemburgo: Publications Office of the European Union, 2010.

FIGUEIREDO, Elisabete. Um rural para viver, outro para visitar: o ambiente nas estratégias de desenvolvimento para as áreas rurais (tese). Universidade de Aveiro, 2003.

. "Imagine there's no rural: the transformation of rural spaces into places of nature conservation in Portugal". European Urban and Regional Studies, v. 15, n. 2, p. 159-71, abr. 2008. 
. "Introdução: um rural cheio de futuros?". In FIGUEIREDO, Elisabete (org.). $O$ rural plural: olhar o presente, imaginar o futuro. Castro Verde: 100Luz, 2011, p. $13-46$.

FRIEDMANN, John. Empowerment: uma politica de desenvolvimento alternativo. Trad. Carlos Silva Pereira. 1. ed. Oeiras: Celta Editora, 1996.

GUIZO, Aida Maria Valadas de Lima Pinto. Agricultura e ruralidade em Portugal: 1970-2000 (tese). Instituto Universitário de Lisboa, 2011.

HAMMER, Thomas. "Protected areas and regional development: conflicts and opportunities". In MOSE, Ingo (ed.). Protected areas and regional development in Europe: towards a new model for the 21st century. 1. ed. Aldershot: Ashgate, 2007, p. 21-36.

HOGGART, Keith et al. Rural Europe: identity and change. 1. ed. Londres: Arnold, 1995. JOHNSON, Stanley P. e CORCELLE, Guy. The environmental policy of the European Communities. 2. ed. Londres: Kluwer Law International, 1997.

JOLLIVET, Marcel. "Les métamorphoses d'un rural incertain”. In ___ (dir.). Vers un rural postindustriel: rural et environnement dans huit pays européens. 1. ed. Paris: L'Harmattan, 1997, p. 351-71.

LOWE, Philp e BALDOCK, David. "Integration of environmental objectives into agricultural policy making". In BROUER, Floor e LOWE, Philip (eds.). CAP regimes and the European countryside: prospects for integration between agricultural, regional and environmental policies. Wallingford: CABI Publishing, 2000, p. 31-52.

et al. "National cultural and institutional factors in CAP and environment". CAP regimes and the European countryside: prospects for integration between agricultural, regional and environmental policies. Wallingford: CABI Publishing, 2000, p. 257-80. MANSINHO, Inês e SCHMIDT, Luísa. "Réinventer le rural par l'environnement". In JOLLIVET, Marcel (dir.). Vers un rural postindustriel: rural et environnement dans huit pays européens. 1. ed. Paris: L'Harmattan, 1997, p. 261-308.

MATHIEU, Nicole e JOLLIVET, Marcel (dirs.).Du ruralà l'environnement: la question de la nature aujourd'hui. Paris: A.R.F. Editions/L'Harmatan, 1989.

MORMONT, Marc. Parcs naturels et gestion de l'espace rural. Luxemburgo: Fondation Universitaire Luxembourgeoise, 1984.

MOSE, Ingo e WEIXLBAUMER, Norbert. "A new paradigm for protected areas in Europe?". In MOSE, Ingo (ed.). Protected areas and regional development in Europe: towards a new model for the 21st century. 1. ed. Aldershot: Ashgate, 2007, p. 3-19.

PINTO-CORREIA, Teresa. "A importância do envolvimento a nível local na implementação e impacto das medidas agro-ambientais: avaliação de quatro experiências europeias". Actas do I Congresso de Estudos Rurais. Vila Real: Universidade de Trás-os-Montes e Alto Douro, 2001.

POLÁKOVÁ, Jana et al. Addressing biodiversity and habitat preservation through measures applied under the Common Agricultural Policy. Report prepared for DG 
Agriculture and Rural Development. Londres: Institute for European Environmental Policy, 2011.

RODRIGO, Isabel. "Política agro-ambiental". Actas do I Congresso de Estudos Rurais. Vila Real: Universidade de Trás-os-Montes e Alto Douro, 2001.

SANTOS, José Manuel Lima et al. Estudo sobre a integração da gestão da rede Natura 2000 na Estratégia Nacional de Desenvolvimento Rural 2007-2013. Lisboa: Instituto de Conservação da Natureza. 2006.

Dados sobre a programação financeira da Politica de Desenvolvimento Rural 2014-2020 consultados em The European Network for Rural Development (ENRD). Disponível em: https://enrd.ec.europa.eu/. Acesso em: 15 jun. 2019. 


\title{
Capítulo 5 \\ Turismo, cultura, criatividade e desenvolvimento local: casos de estudo em municípios de pequeno porte demográfico em Portugal
}

\author{
Eduarda Marques da Costa \\ Larissa de Mattos Alves \\ Angela Maria Endlich
}

\section{Introdução}

Nas últimas décadas, o turismo tem vindo a afirmar-se como uma estratégia de desenvolvimento local de municípios de pequeno porte demográfico, em particular, os localizados em regióes menos densamente povoadas e não polarizadas por grandes metrópoles (Duxburyet al., 2018; Endlich, 2006; Gomes, 2012; Selada et al., 2011). Esses municípios, encabeçados por cidades e vilas de pequeno porte demográfico, caraterizam-se por economias pouco diversificadas, muito ligadas a atividades agrícolas, a serviços econômicos de baixo valor acrescentado e serviços sociais básicos e procuram, por isso, encontrar novas formas de diversificação das suas bases econômicas e de intermediação entre os níveis local e regional ou nacional (Marques da Costa, 2002), encontrando no seu patrimônio natural, cultural, histórico e paisagístico novos produtos geradores de emprego e renda para esses municípios.

Contudo, esses municípios, pelo seu contexto geográfico - muitos se localizam em regiôes rurais e em perda ou estagnação demográfica - e pelas condicionantes decorrentes da fraca acessibilidade, quer por rodovia, quer por ferrovia, ou ainda pela inexistente ligação aérea, registam grandes dificuldades de afirmação, não captando novos residentes nem novas empresas e empregos (Endlich, 2006; Marques da Costa, 2017). 
O presente capítulo centra-se nessas questões, procurando discutir qual o papel que o turismo pode ter no desenvolvimento dos municípios de pequeno porte. Para tal, recorre à apresentação de três casos de estudo localizados no território português, mostrando como o turismo, a cultura e a criatividade se juntam para viabilizar novas atividades e aproveitando recursos endógenos, com a visão de projetar esses municípios e suas pequenas cidades e vilas numa escala que ultrapassa o local e se estende à escala nacional e internacional. A segunda questão de investigação é complementar da anterior e procura verificar qual o papel que os agentes locais, em particular os municípios, têm na dinamização dessas atividades, o que remete ao papel do planejamento no processo de desenvolvimento desses territórios.

$\mathrm{O}$ artigo estrutura-se em cinco partes: a primeira corresponde à presente introdução, que é seguida, na parte segunda, pela discussão teórica de conceitos e reflexões relacionadas com o papel do turismo, das atividades culturais e das atividades criativas. Na terceira parte são introduzidos os três casos de estudo da realidade portuguesa, os municípios de pequeno porte de Montemor-o-Novo, Coruche e Óbidos, sendo feita uma apresentação das suas características socioeconômicas. No seu seguimento surge a parte quatro, onde se discute a relação entre as atividades turísticas na sua base cultural e criativa, considerando os recursos mobilizados e agentes promotores. A quinta, e última parte, estrutura-se em torno de um conjunto de considerações de resposta às questões de investigação, demonstrando-se a importância que o poder local e que o processo de planejamento detiveram na mobilização das estratégias de desenvolvimento desses municípios e tendo em conta o seu patrimônio e os seus agentes de desenvolvimento.

\section{“Turismo", "cultura" e "criatividade" na base de estratégias para o desenvol- vimento local}

A cultura tornou-se um recurso crucial na nova economia, refletida na utilização do patrimônio cultural nas estratégias de desenvolvimento da União Europeia. É nesse contexto que a cultura é cada vez mais utilizada pelas cidades e regióes como meio de desenvolver a componente socioeconômica, mas, simultaneamente, preservar a identidade cultural dos lugares (Durmaz et al., 2010).

É, por isso, consensual o reconhecimento da importância do patrimônio cultural no desenvolvimento do turismo e, dessa forma, como motor de desenvolvimento da economia, gerando emprego e produto e contribuindo para o 
aumento da competitividade dos lugares. A cultura surge, assim, como estratégia de "renovação econômica e urbanística" das grandes cidades, citando-se frequentemente o exemplo de Barcelona, mas também de cidades médias no quadro europeu, como as cidades industriais de Glasgow, Hamburgo e Bilbao, ou dos centros universitários regionais de Bolonha e Montpellier (Casella et al., 2010, p. 156).

A sua relevância nas cidades e vilas de pequena dimensão é menos discutida, mas vai sendo cada vez mais comum que os municípios de pequeno porte, e as cidades e vilas que neles se inserem, incluam nos seus planos diretores e noutros documentos estratégicos a ambição de promover o setor do turismo baseado nos recursos locais, dos naturais aos culturais, como uma alternativa de desenvolvimento (Duxburyilva e Vinagre de Castro, 2018; Endlich, 2006; Gomes, 2012; Inteli, 2011; Selada et al., 2011).

Segundo o relatório da OECD de 2009, dedicado a "O impacto da cultura no turismo", os principais motores das políticas que combinam turismo e cultura são: a valorização e a preservação do patrimônio; o desenvolvimento econômico e a criação de emprego; a regeneração física e econômica dos territórios, nomeadamente das cidades; o reforço e a diverficação dos produtos turísticos; captar ou manter residentes nos locais, nomeadamente nos territórios em perda demográfica; e valorização da cultura, promovendo o seu entendimento como um instrumento de identidade e patrimônio (OECD, 2009).

Em vários casos são identificados benefícios do reforço da contribuição da cultura para o aprofundamento competitivo dos produtos turísticos, surgindo a identidade cultural como o elo entre o turismo e esses territórios. A capacidade de dar visibilidade regional, nacional e internacional à cultura local depende fortemente das forças vivas locais, que vão desde o município aos empresários. Mas essa dinâmica depende também dos poderes públicos regionais e nacionais, que podem promover a melhoria das acessibilidades ou o fornecimento de serviços a esses pequenos municípios, dotando-os de maior capacidade atrativa de visitantes (Inteli, 2011).

Marujo (2014, p. 2) refere que "Durante a maior parte do séc. XX, e de acordo com a OECD (2009), a cultura e o turismo foram vistos como aspectos distintos dos destinos. [...] esta visão mudou gradualmente no final do século, uma vez que o papel da cultura foi um elemento distintivo de outros destinos. Como se pode verificar no quadro seguinte, a articulação crescente entre a cultura e o turismo foi estimulada por uma série de fatores (tabela 1)”. 
Seguindo esse raciocínio, a emergência e a afirmação dos fatores apontados na tabela conferem à cultura o papel de produto turístico e de imagem estratégica.

Simultaneamente, essa valorização faz com que o turismo seja parte inerente das estratégias de preservação do patrimônio. Vários estudos apontam para a relação entre turismo, cultura e criatividade, argumentando que a originalidade e a diversidade da oferta cultural protegem a identidade local, atraem pessoas criativas e promovem a competitividade sustentável dos destinos (Florida, 2002, e Richards e Wilson, 2006, apud Durmaz et al., 2010). Os processos de desenvolvimento local/regional estão eminentemente associados à relação turismo-cultura, mas também "os processos de desenvolvimento local/regional não podem dissociar-se da criatividade, sendo que os conceitos e elementos que os sustentam têm na sua génese a criatividade dos indivíduos, das empresas, das instituiçóes e dos diversos ativos territoriais" (Fernandes et al., 2016, p. 1).

Tabela 1 - Fatores que estimularam a relação entre cultura e turismo

\begin{tabular}{|c|c|}
\hline Do lado da procura & Do lado da oferta \\
\hline $\begin{array}{l}\text { Maior interesse na cultura, principalmente } \\
\text { como fonte de identidade e de diferenciação } \\
\text { em face da globalização; } \\
\text { Aumento dos níveis de capital cultural } \\
\text { estimulado pelo crescimento da escolaridade; } \\
\text { Envelhecimento das populações nas regiões } \\
\text { desenvolvidas; } \\
\text { Estilos de consumo pós-moderno (ênfase no } \\
\text { desenvolvimento pessoal); } \\
\text { Desejo de formas diretas de experiência; } \\
\text { Importância crescente da cultura imaterial e } \\
\text { o papel da imagem e da atmosfera; } \\
\text { Aumento da mobilidade facilitando o acesso } \\
\text { a outras culturas. }\end{array}$ & $\begin{array}{l}\text { Desenvolvimento do turismo cultural para } \\
\text { estimular o emprego; } \\
\text { Turismo cultural visto como um mercado } \\
\text { em crescimento e como um turismo de } \\
\text { "qualidade"; } \\
\text { Aumento da oferta cultural como resultado } \\
\text { do desenvolvimento regional; } \\
\text { Maior acesso às informações sobre a cultura e } \\
\text { o turismo por meio das novas tecnologias; } \\
\text { Surgimento de novas nações e regióes que } \\
\text { procuram estabelecer uma identidade } \\
\text { cultural distinta; } \\
\text { Problemas de financiamento cultural } \\
\text { relacionados com o aumento da oferta da } \\
\text { cultura. }\end{array}$ \\
\hline
\end{tabular}

Fonte: Marujo (2014, p. 2), baseado em OECD (2009, p. 20).

Esse contexto leva-nos para a discussão do que são as atividades criativas e o turismo criativo e o que têm vindo a representar para as políticas e para o desenvolvimento do território, como geradoras de emprego e promotoras de renda econômico local e da própria participação e integração social.

A designação atividades criativas tem surgido eminentemente associada às "cidades criativas", movimento que releva a importância econômica e social 
das atividades culturais existentes especificamente em cada território e a sua relação com as indústrias criativas, bem como o seu impacto na economia urbana (Landry, 2010; Florida, 2002 e Pratt, 2008, apud Almeida, 2018). Nesse campo, evidenciam-se as especificidades regionais que fomentam a existência de produtos e de ambientes criativos, que crescentemente se vão associando à cultura e ao patrimônio histórico local. Essas especificidades tornam os lugares únicos, sejam eles cidades de grande dimensão ou vilas e municípios de pequeno porte (Landry, 2010, p. 8-9, apud Almeida, 2018).

Quanto ao turismo criativo, este é definido como o "turismo que oferece aos visitantes a oportunidade de desenvolver o seu potencial criativo através da participação ativa em cursos e experiências de aprendizagem que são características do destino de férias onde eles são realizados" (Richards e Raymond, 2000, p. 18). Richards e Wilson (2006, p. 1218) argumentaram que o que distingue o turismo criativo dos espaços criativos ou eventos criativos é que "o turismo criativo depende muito mais do envolvimento ativo dos turistas”. Nesse sentido, a relação entre criatividade e turismo aponta para várias abordagens ao termo criatividade, incluindo o trabalho de pessoas criativas, produtos, processos e ambientes criativos (Richards, 2011, apud Richards, 2013). O mesmo autor destaca que a criatividade tornou-se cada vez mais importante para o desenvolvimento do turismo nas cidades, sendo usado de várias maneiras, incluindo: "o desenvolvimento de produtos e experiências turísticas; a revitalização de produtos existentes; a valorização de ativos culturais e criativos; o fornecimento de desdobramentos econômicos para o desenvolvimento criativo; o uso de técnicas criativas para aprimorar a experiência turística; e considerar a atmosfera aos lugares" (Richards, 2013, p. 3).

Para além do patrimônio cultural, encontramos outras manifestaçôes culturais que são igualmente mobilizadoras do desenvolvimento turístico. É o caso dos eventos culturais, nos quais se incluem festivais de música, teatro e afins, bem como a realização de feiras ou de concursos de natureza diversificada. Essas atividades podem surgir de forma combinada (mostras de gastronomia, feiras de artesanato ou outros eventos ligados à história local, como as feiras medievais), de forma organizada, em municípios ou vilas afastados dos principais centros urbanos, em contexto rural ou menos urbanizado.

Os eventos transformaram-se, assim, num fator muito poderoso de desenvolvimento, pois fornecem a atividade e a motivação necessárias para animar espaços criativos. Richard (2013) refere que, por meio de programação 
cuidadosa e seleção de portfólio de eventos, é possível ligar a criatividade da populaçáo local ao setor cultural e criativo e aos visitantes.

Duxbury et al. (2018, p. 78), no contexto de um projeto de pesquisa "CREATOUR - Desenvolver Destinos de Turismo Criativo em Cidades de Pequena Dimensão e Áreas Rurais”, referem a afirmação do turismo criativo nas pequenas cidades em contexto rural, baseado na promoção da cultural local e na sua expressão artística, "na sua relação com a natureza e os lugares", apontando atividades diversificadas. Aqui, contam-se

oficinas e workshops, atividades de artesanato reportadas aos setores do têxtil, cerâmica, couro, metais, madeira, etc.; oficinas de belas artes relacionadas com pintura, escultura, desenho e ilustração; oficinas de fotografia, vídeo e artes digitais; oficinas de artes cênicas e residências artísticas participativas e comunitárias; sessões de contadores de histórias; oficinas de gastronomia; 'caminhadas e visitas' criativas e interpretativas envolvendo atividades de criação; oficinas de tradições ancestrais e atividades de participação ativa; e a produção de matérias-primas e ciclos de trabalho - de sal, linho, lã, barro, mármore, vime, etc. (Duxbury et. al., 2018, p. 79).

Em termos internacionais, o reconhecimento da importância da criatividade está patente na existência da Rede de Cidades Criativas da Organização das Naçóes Unidas para a Educação, a Ciência e a Cultura (UNESCO), criada em 2004, e com 180 cidades de 72 países. Nestas, o patrimônio é reconhecido como um dos principais fatores impulsionadores da estratégia criativa aplicados a centros urbanos ou vilas com grande envolvência patrimonial, conferindo reconhecimento em termos de conservação e estimulando a procura turística (Almeida, 2018).

Essa estratégia permite evidenciar a afirmação de uma "marca-lugar", onde o processo histórico de evolução do destino turístico condiciona fortemente a imagem a projetar no futuro pelo que o turismo beneficia da cultura pela forma como ela fortalece a identidade de cada destino.Assim, a participação e o forte envolvimento dos agentes e comunidades locais nos processos de planejamento, de desenvolvimento e de execução de atividades de turismo são fundamentais para assegurar a conciliação entre a valorização econômica, a preservação do patrimônio e a preservaçáo dos interesses da comunidade (Mateus, 2010).

Entretanto, não se pode incorrer na ilusão de que são apenas positivas as implicaçóes do turismo. Os desafios para o turismo estão nas escalas municipais, regionais, estaduais e na escala nacional (Barros, 2015). 
O contexto geográfico de afastamento dos grandes centros urbanos levanta também a questão da acessibilidade por parte dos turistas a essas pequenas localidades. Falamos da disponibilidade de serviços de transporte à disposição dos turistas eventualmente enquadrados em roteiros que incluem patrimônio natural e gastronômico e necessariamente apoiados por informação relevante para a sua interpretação. Falamos ainda de alojamentos turísticos, que, nos municípios de pequeno porte, são escassos e pouco diversificados. Por outro lado, a chegada de turistas em pequenas localidades pode acarretar resistência e insegurança por parte dos moradores locais, acostumados com a tranquilidade e o clima familiar dos pequenos centros. A concentraçáo de visitantes pode também aumentar o tráfego, os congestionamentos e a poluição, interferindo na rotina da maioria dos trabalhadores das pequenas cidades, enquanto os benefícios econômicos da chegada desses visitantes ficam restritos a alguns empresários. Porém, quando esses ganhos econômicos são socialmente distribuídos e, ainda, estimulam a valorização e a preservação da natureza e da cultura locais, implicaçóes positivas da atividade podem ser observadas nos pequenos municípios turísticos (Endlich, 2013).

\section{Método de pesquisa}

Em termos metodológicos, o presente texto recorreu a uma revisão bibliográfica apresentada na primeira parte, mas outras fontes foram necessárias para o desenvolvimento das restantes partes: recolha de informação no Instituto Nacional de Estatística relativa a dados demográficos e de emprego; recolha de documentos estratégicos, jornais e outros meios de comunicação que reportem informaçóes dos municípios. Para além das fontes anteriores, foi de extrema relevância o trabalho de campo realizado por meio de visitas e da observação da rotina dos moradores e turistas nesses municípios. A observação priorizou os usos dos espaços públicos, de lazer e de eventos, com atenção às implicaçóes do turismo nas condiçóes sociais dos moradores. Entrevistas não estruturadas, realizadas a gerentes de equipamentos e serviços de hospedagem, alimentação e de organização de eventos, possibilitaram uma melhor compreensão das necessidades dos municípios no domínio da oferta turística, mas também um balanço sobre as novas oportunidades que se abriram com o desenvolvimento de novas atividades 
O presente trabalho tem como base três municípios: Montemor-o-Novo, Coruche e Óbidos. Esses municípios são de pequena dimensão e, para além disso, nos casos de Coruche e Óbidos, as suas sedes municipais não são lideradas por "cidades", mas estão classificadas apenas como "vilas". Importa assim descrever os critérios que estiveram presentes na escolha dos três casos de estudo portugueses.

Mapa 1 - Localização dos casos de estudos - os municípios de Montemor-o-Novo, Coruche e Óbidos - Portugal

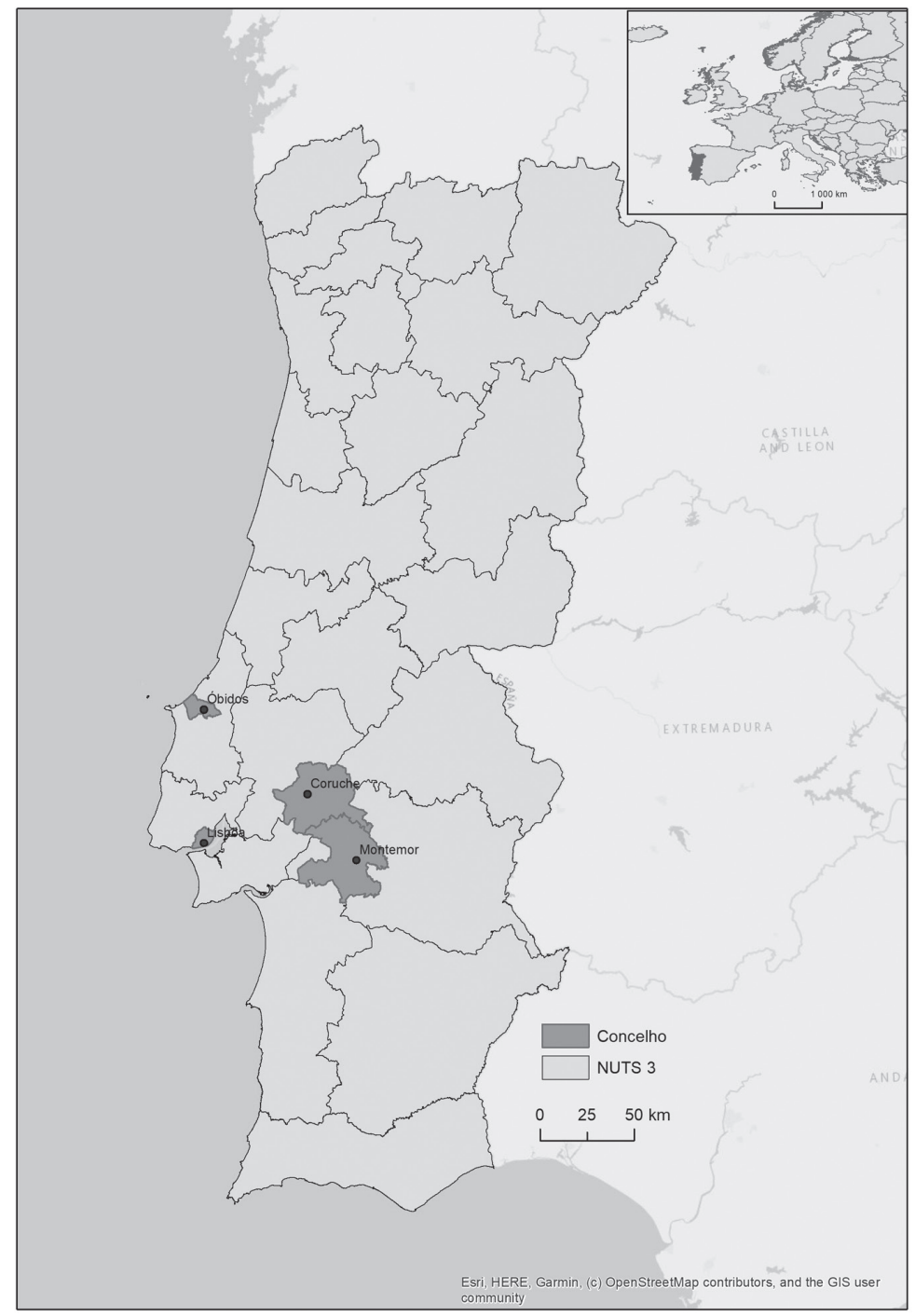

Fonte: CAOP (2014) com elaboração própria. 
O primeiro relaciona-se com os que são considerados municípios de pequeno porte demográfico. Em Portugal, Marques da Costa (2002, 2017) apresenta uma tipologia de cidades, referindo que as cidades de porte médio na realidade portuguesa podem oscilar entre $10 \mathrm{mil}$ habitantes e $100 \mathrm{mil}$ habitantes, enquanto os municípios de pequeno porte, que a autora designa como "polos locais", oscilam entre 5 mil e 15 mil habitantes, consoante se localizam no litoral ou no interior, respectivamente. Assim, a autora refere que, para a realidade portuguesa, é de enorme relevância distinguir as cidade e vila que se integram em municípios do litoral ou na envolvente das grandes metrópoles de Lisboa e do Porto (territórios de maior densidade demográfica e com uma rede urbana e de serviços mais potente) e os municípios do interior ou em contexto territorial de cariz mais rural (o que corresponde a territórios de menor densidade demográfica, envelhecimento e menor expressão e capacitação empresarial). Marques da Costa (2017) refere ainda que a localização geográfica e a inserção regional em termos de acessibilidade e relevância funcional fazem com que aglomerados com menos de 20 mil habitantes e vilas com menos de 10 mil habitantes possam assumir protagonismo na organização regional do território português. Polos com menos de 10 mil a 20 mil habitantes localizados no interior do país assumem papeis de intermediação e estruturação regional, o que aponta para critérios que ultrapassam a dimensão demográfica e se estendem à importância funcional e aos níveis de qualidade de vida que podem ser atingidos nas diferentes aglomerações.

O segundo critério relaciona-se com a existência de patrimônio histórico-cultural. O passado longínquo, as diversas heranças culturais e os monumentos de primeira grandeza, como os castelos, vilas muradas e paisagens singulares, são relativamente comuns em Portugal.

Por fim, o terceiro critério diz respeito ao envolvimento dos agentes locais, que, nos três casos de estudo apresentados, é evidente e assume participaçóes de forma diferenciada. Vejamos com detalhe como o turismo ligado ao patrimônio cultural e à produção de atividades criativas se desenvolveram nos três casos de estudo portugueses. 


\section{Enquadramento demográfico e econômico dos municípios de Montemor- -o-Novo, Coruche e Óbidos, em Portugal}

Montemor-o-Novo tem sua origem em época indeterminada, mas as primeiras notícias de sua existência como urbe são do ano 1181 e se origina como vila intramuros. O Castelo de Montemor, com quase dois quilômetros de muralha, foi um dos maiores de Portugal, palco de decisóes no país e sede de cortes. "Nos séculos XV e XVI, a vila atingiu grande prosperidade e, em 1495, D. Manuel I tomou a decisão, neste castelo, de mandar Vasco da Gama à descoberta do caminho marítimo para a Índia” (Parreira, 2015, p. 39). A vila e o castelo sofreram sérias deterioraçóes com ataques, incêndios e com o terremoto de 1755. Apesar das históricas tentativas de reedificações no castelo e na muralha, a "zona da vila intramuros é actualmente uma zona arrasada, sem vestígios aparentes de uma das cidades mais importantes a nível regional na Idade Media” (Laranjeira, 2011, p. 65). Diferentemente de outras localidades, que, devido ao aumento populacional, cresceram para extramuros, em Montemor-o-Novo, a população abandonou "a zona amuralhada, demolindo casas e aproveitando os respectivos materiais para novas construçóes na zona baixa, situada junto à estrada real, onde se multiplicava a construção de estalagens, casas de comércio, oficinas e onde se realizavam as feiras" (Laranjeira, 2011, p. 58). Após mudança da população, o poder local tentou ainda se manter ali e resgatar as populaçóes, porém acabou também se mudando para fora da zona protegida. Atualmente, da cidade murada, restam ruínas das muralhas e torres e algumas construçóes em crítico estado de conservação, como igrejas e conventos utilizados como centros de interpretação ou fechados para restauro.

Do ponto de vista demográfico, o município de Montemor-o-Novo encontra-se em declínio populacional e elevado processo de envelhecimento.

Quadro 1 - População Residente nos três municípios em estudo, 1991-2018

\begin{tabular}{lcccccc}
\hline & \multicolumn{3}{c}{ N.o } & \multicolumn{3}{c}{ Tx. De Variaçáo (\%) } \\
\hline & $\mathbf{1 9 9 1}$ & $\mathbf{2 0 0 1}$ & $\mathbf{2 0 1 1}$ & $\mathbf{2 0 1 8}$ & $\mathbf{1 9 9 1 - 2 0 1 8}$ & $\mathbf{2 0 1 1 - 2 0 1 8}$ \\
\hline Portugal & 9.950 .029 & 10.394 .669 & 10.542 .398 & 10.276 .617 & 3,3 & $-2,5$ \\
\hline $\begin{array}{l}\text { Montemor- } \\
\text { o-Novo }\end{array}$ & 23.567 & 21.279 & 17.275 & 15.740 & $-33,2$ & $-8,9$ \\
\hline Coruche & 18.692 & 18.545 & 19.762 & 17.629 & $-5,7$ & $-10,8$ \\
\hline Óbidos & 11.203 & 11.004 & 11.768 & 11.719 & 4,6 & $-0,4$ \\
\hline
\end{tabular}

Fonte: INE, Censos e *Estimativas da População. 
Quadro 2 - Densidade Populacional e Índice de Envelhecimento nos municípios em estudo, 1991-2018

\begin{tabular}{|c|c|c|c|}
\hline \multirow[b]{2}{*}{ Concelhos } & \multicolumn{2}{|c|}{ Densidade Populacional } & Índice de Envelhecimento \\
\hline & $\mathrm{N} .{ }^{\circ} / \mathrm{km}^{2}$ & $\begin{array}{c}\text { Tx. Variação } \\
(\%)\end{array}$ & \\
\hline
\end{tabular}

$$
\begin{array}{lllllllll}
11991 & 22001 & 22011 & 22018 & 11991- & 22011- & 119912200122011 & 22018 \\
2018 & 2018 & 1991 & 22018
\end{array}
$$

\begin{tabular}{lcccccccccc}
\hline Portugal & 107,1 & 112,4 & 114,0 & 111,4 & 4,0 & $-2,5$ & 72 & 103 & 128 & 159 \\
\hline $\begin{array}{l}\text { Montemor- } \\
\text { o-Novo }\end{array}$ & 21,1 & 19,1 & 14,0 & 12,8 & $-39,3$ & $-8,6$ & 131 & 216 & 238 & 281 \\
\hline Coruche & 15,1 & 15,1 & 17,7 & 15,8 & 4,5 & $-10,7$ & 129 & 207 & 243 & 300 \\
\hline Óbidos & 78,6 & 76,4 & 83,1 & 82,8 & 5,4 & $-0,4$ & 97 & 142 & 155 & 189 \\
\hline
\end{tabular}

Fonte: INE, Censos e *Estimativas da População.

Por outro lado, regista uma fraca densidade populacional, sendo que o território desse município se encontra integrado regionalmente em territórios rurais. Entre 1991 e 2018, o município perdeu 1/3 dos seus habitantes. Nesse período, acentuou-se a desigualdade do ponto de vista da ocupação do território regional, uma vez que o decréscimo populacional de Montemor-o-Novo $(-8.9 \%)$ foi relativamente superior ao registado no país (-2,5\%). Esse declínio traduz-se numa menor densidade populacional (quase 1/10 da média do país) e num elevadíssimo índice de envelhecimento, que duplicou entre 1991 e 2018.

Olhando a estrutura do emprego, verificamos que o turismo tem pequena participação em Montemor-o-Novo (6,9\% no alojamento, restauração e similares e 4,9\% nas atividades artísticas, de espetáculos, desportivas e recreativas e outras, INE, 2017), sendo dominada pela agricultura e pela produção animal (25,2\%), com destaque à criação de bovinos, mas tais atividades econômicas não foram capazes de evitar o processo chamado em Portugal de desertificação populacional acentuada, que se agrava devido ao envelhecimento da população residente. 
Quadro 3 - Estrutura do emprego por atividade econômica nos municípios em estudo, 2017 (\%)

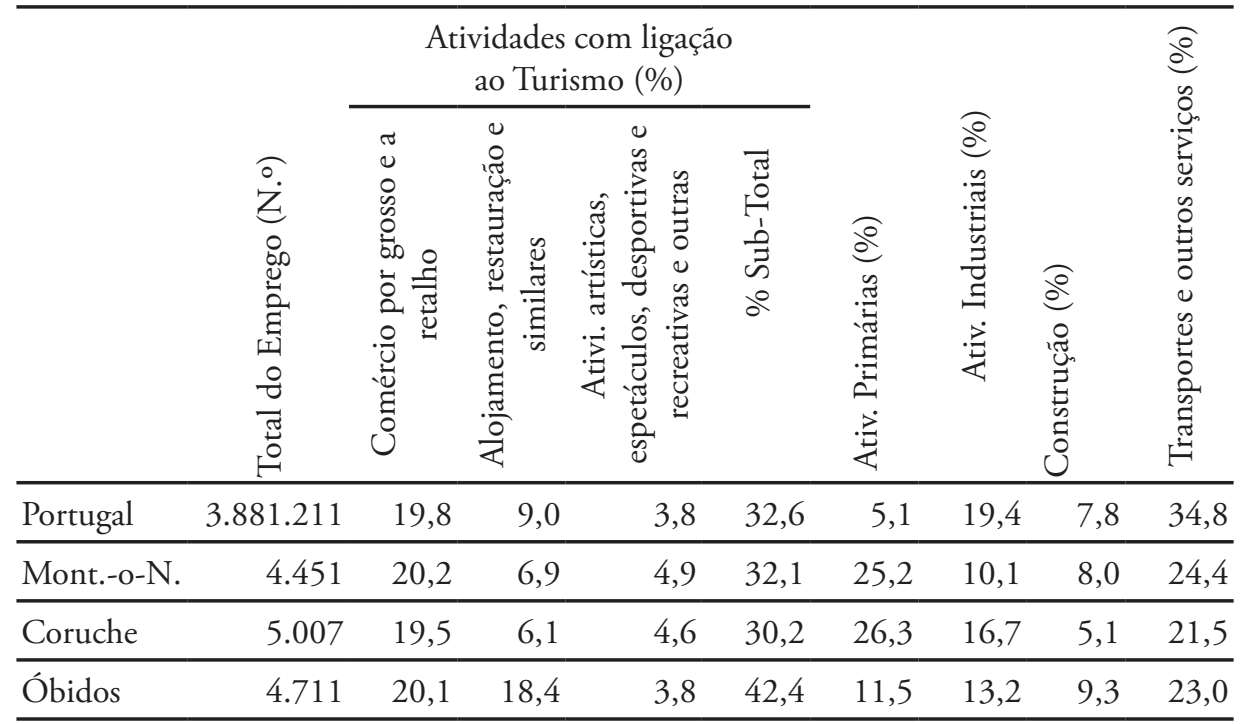

Fonte: INE, Sistema de contas integradas das empresas.

Mudando de caso de estudo, falamos agora do segundo. O município de Coruche, é um concelho vizinho de Montemor-o-Novo, mas já localizado no Distrito de Santarém. A distância da citada cidade vizinha é de 47 quilômetros e está a oitenta quilômetros de Lisboa. A populaçáo do concelho é de pouco mais de 19 mil habitantes, distribuídos em seis freguesias. Na sede do concelho, a Vila de Coruche, vivem 9 mil pessoas, mas os valores de baixa densidade e envelhecimento são muito próximos dos verificados em Montemor-o-Novo (quadros 1 e 2).

Efetivamente, Coruche e Montemor-o-Novo, devido à proximidade, apresentam processos de ocupação semelhantes. No entanto, em Coruche, construçóes como o castelo e as muralhas foram completamente destruídas. Existem poucas evidências sobre a história de Coruche, apenas que era considerada uma vila estratégica por estar localizada nas margens do rio Sorraia - via utilizada, historicamente, para conquistas e comércio.

A agricultura do concelho e tem sua origem durante as ocupaçóes romanas. Coruche é um município predominantemente rural, com uma elevada área florestal, tendo, em 2017, 26,3\% do emprego do concelho ocupado na atividade agrícola. "A especialização produtiva deste concelho apresenta um 
significativo vínculo à herança de um passado marcado por uma profunda ligação à terra e à cultura tradicional, predominando a produção de arroz, milho, tomate e produtos hortícolas" (Câmara Municipal de Coruche, 2009, p. 18). Em relação às suas grandes áreas de floresta, Coruche se destaca como maior produtor mundial de cortiça, "representando 2,2\% do total das exportaçóes portuguesas" (APRCR, 2015, p. 18). A tiragem da cortiça envolve dinâmica de trabalho temporária e informal, que, "apesar de não se reflectirem nas estatísticas oficiais, apresentam efectivos contributos para a economia do concelho" (Câmara Municipal de Coruche, 2009, p. 16).

Diferentemente da frágil contribuição do turismo na economia de Coruche e Montemor-o-Novo, Óbidos tem sua economia fortemente dependente da chegada de turistas. Óbidos, localizada no distrito de Leiria, a 100 quilômetros de Lisboa, é uma das mais famosas vilas intramuros portuguesas, onde vivem 2.200 moradores. Essa freguesia é sede do município com o mesmo nome, que reúne pouco mais de 11 mil habitantes. Contudo, Óbidos é, dos três casos de estudo, o único que registou um decréscimo populacional mais favorável que a média nacional: entre 2011 e 2018, Portugal perde 2,5\%, e Óbidos apenas decresce -0,4\% (Quadros 1 e 2, p. 122-23).

Presente na história do país desde o século XII, foi palco de disputas, batalhas, conquistas e "encruzilhada de diversos povos e culturas - Celtas, Romanos, Visigodos, Árabes e Judeus [...]. Óbidos assume ainda uma especial singularidade pela sua íntima relação com as Rainhas de Portugal" (Fidalgo, 2009, p. 44), que recebiam a vila como presente de casamento. Até o final no século XV, a vila teve projeção real e foi importante centro da cultura e da arte portuguesa. O Castelo volta a ser centro de atençóes em 1910, quando foi classificado como monumento nacional, e novamente em 1930, quando foi cenário de restauros e reconstruçôes com recursos federais. Em 1951, além do castelo, toda a vila muralhada foi classificada como monumento nacional e recebeu, em um de seus edifícios históricos, a primeira pousada portuguesa (Fidalgo, 2009). Segundo Leal (2013), as principais intervenções e transformaçóes na Vila, essencialmente rural, aconteceram nas duas últimas décadas no século XX, entre os anos de 1980 e 2000. Por iniciativa da administração pública municipal, foram realizados investimentos em infraestrutura, educação, restauração do patrimônio material e apoio à produção artística e cultural, como bandas, corais, folclore, literatura, escultura e pintura. Além dos recursos culturais disponíveis na vila, o município também dispóe de recursos naturais, como o mar, a floresta e a 
lagoa, e produtos turísticos ligados a eles, como campos de golfe, condomínios de segunda residência, resorts e spas.

O papel dos agentes e dos instrumentos de planejamento no desenvolvimento do turismo assente nas atividades criativas nos três municípios portugueses

\section{i. Montemor-o-Novo - o setor criativo como o motor do turismo}

Desde o início do século que o quadro de estagnação econômica observou uma pequena mudança, especialmente na sede urbana, devido a uma nova especialização econômica ligada às Artes. Conforme indica diagnóstico elaborado pela Câmara Municipal, Montemor-o-Novo "tem revelado dinâmicas de produção e animação cultural [permitindo] não só dinamizar o setor cultural endógeno como ainda atrair e acolher estruturas de criação artística exógenas" (Câmara Municipal de Montemor-o-Novo, 2015, p. 39).

A nova especialidade produtiva, ligada às artes e que atrai visitantes, surgiu por iniciativa recente de um único artista: Rui Horta. Esse dançarino e coreógrafo português chegou a Montemor-o-Novo no ano 2000, depois de dez anos morando na Alemanha, período que deu ao seu nome projeção internacional. $\mathrm{O}$ artista observou que em Portugal existiam muitos espaços para apresentaçóes culturais, mas poucos espaços reservados como apoio aos produtores de atividades culturais. Em uma parceria com a Câmara Municipal de Montemor-o-Novo, o coreógrafo conseguiu o espaço degradado, no interior das muralhas do Castelo, para instalar seu centro inovador e interdisciplinar de artes performáticas, o Espaço do Tempo (Goulart, 2010).

O projeto congrega, para além da autarquia, quatro estruturas de criação, promoção e difusão artística, a saber: O Espaço do Tempo - Associação Cultural, a Associação Cultural de Arte e Comunicação Oficinas do Convento, o Projecto Ruínas Associação e a Alma d'Arame - Associação Cultural.

A proposta consiste especialmente em uma incubadora de produçôes culturais, que recebe projetos convidados na modalidade de residência, oferecendo treinamentos avançados, espaço para os artistas compartilharem habilidades, visôes, métodos e imersão no processo de produção devido ao espaço inspirador e isolado (O Espaço do Tempo, 2017). 
O espaço recebe artistas iniciantes ou emergentes de toda a Europa, que leva a Montemor-o-Novo visibilidade nacional e internacional, possibilitando também a internacionalização de artistas portugueses (Canelas, 2011). Entre as críticas ouvidas no concelho sobre a ausência de apoio do governo federal está o cancelamento da reforma do local cedido ao projeto. Contudo, mesmo sem as condiçóes financeiras adequadas, o Espaço "recebe os criadores nacionais e estrangeiros para que nele possam criar e realizar projectos; ao seu dispor têm 14 quartos e quatro estúdios". Algumas partes que ameaçam ruir estão em desuso, mas, ainda assim, o Espaço do Tempo "é uma das maiores estruturas do País ao nível das artes performativas e uma referência a nível nacional e internacional" (Goulart, 2010). O projeto recebe aproximadamente 700 artistas, que permanecem entre quinze dias e um mês para a residência, e resulta, em média, em quarenta projetos apoiados anualmente (Goulart, 2010).

Montemor-o-Novo era apresentada por seus moradores como "uma das terras mais atravessadas e menos visitadas de Portugal”, mas, com a instalação do centro cultural, o cenário está mudando. "Montemor-o-Novo recebe cerca de 10 mil turistas por ano, tendo vindo a aumentar gradualmente o número de visitas (dados fornecidos pelo Posto de Turismo Municipal de Montemor-o-Novo)" (Parreira, 2015, p. 47).

Devido à sua história recente, são raros também os estudos e mensuraçóes sobre as implicaçóes socioeconômicas desse projeto a Montemor-o-Novo. No entanto, segundo relatos, é crescente a participação da população nas atividades desenvolvidas no recinto. Trata-se de iniciativa que gera empregos diretos e, indiretamente, os serviços de preparação de cenários e figurinos, som e iluminação e demais equipamentos para eventos, bem como o setor imobiliário e de restauração parecem ensaiar um crescimento motivado pelo projeto. A equipe do Espaço do Tempo conta com 12 colaboradores permanentes, entre técnicos e administrativos, e praticamente todos residem no concelho (Goulart, 2010).

Além das implicaçóes econômicas, o Espaço do Tempo busca imprimir em Montemor-o-Novo avanços socioculturais, realizando trabalhos frequentes com escolas e outros grupos do concelho, oferecendo oficinas, ateliês e buscando a formação, o entretenimento e a sensibilização de públicos para consumo de cultura no concelho e região. A produção cultural é marcante, e outras associaçóes e grupos ligados à música, cultura e artes estão se consolidando no concelho. 
A experiência de Montemor-o-Novo nos permite perceber que, mesmo sem atrativos turísticos de primeira grandeza e sem investimentos públicos, é possível desenvolver o turismo em uma localidade. O impulso para o desenvolvimento de atividades turísticas teve origem no interesse particular e privado de um agente exógeno, que se associa às entidades locais. "Sob uma liderança democrática, mas determinada, sinergias virtuosas foram gradualmente promovidas entre três eixos de desenvolvimento: patrimônio histórico; criação artística; e inclusão social, coesão e emancipação" (André e Abreu, 2010, p. 64).

\section{ii. Coruche - Promover a identidade e cultura local no contexto rural na Leziria do Tejo}

Vários planos de ação foram traçados visando à dinamização socioeconômica de Coruche, porém esses não foram capazes de reverter a estagnação econômica do concelho. Nas entrelinhas de alguns desses documentos, observamos uma tendência no discurso da administração pública em apostar na reinserção econômica de Coruche, por meio do aproveitamento dos transbordamentos das dinâmicas metropolitanas de Lisboa. Muitas expectativas surgiram em torno da construçáo do novo aeroporto de Lisboa, em Montijo, a 56 quilômetros de Coruche, ainda não construído. A possível proximidade do aeroporto também vincula expectativas em relação ao crescimento do turismo regional.

Coruche apresenta uma série de recursos naturais e culturais, que ainda não se concretizaram em produtos turísticos, como áreas protegidas, recursos hídricos como rios, açudes, igrejas, centro histórico, pequenos museus, eventos, paisagem e hábitos bucólicos que remetem ao campo. A ausência de meios de hospedagem também aproxima as localidades de pequeno porte demográfico portuguesas e brasileiras em suas limitaçôes. A demanda por esse serviço é apontada no diagnóstico feito pela Câmara Municipal de Coruche (2009).

Apesar do cenário pouco promissor, Coruche superou um dos principais desafios dos pequenos concelhos portugueses: identificar um segmento de serviços no concorrido mercado turístico europeu, a tauromaquia (Pereira, 2010). A tauromaquia é tradicional em Coruche, e a Praça de Touros, inaugurada em 1966, é um dos principais pontos turísticos da vila. O concelho é reconhecido não só por receber corridas de touros em sua praça, mas também por desenvolver toda uma rede produtiva ligada ao setor. 
A partir dessa característica, Coruche passa a desenvolver esse perfil específico de turismo. Os complexos taurinos são abertos à visitação e permitem apreciar ou realizar atividades ligadas ao touro, ao toureiro e aos cavalos, oferecem serviços de alimentação e, recentemente, inclusive, hospedagem. Outras atividades complementares no ambiente rural comuns, na regiáo, passam a ser oferecidas em Coruche como percursos de caminhada, de bicicleta e a cavalo, descida do rio Sorraia em canoa, birdwatching, pesca esportiva. Alguns eventos realizados em Coruche se destacam por sua particularidade, como o Festival Internacional de Balonismo, em março, Sabores do Toiro Bravo, em abril, e a Feira Internacional da Cortiça, em maio.

Como mencionado, na vila de Coruche, não há nenhum meio de hospedagem tradicional, o que se justifica pela sazonalidade dos eventos realizados e pelo pequeno número anual de visitantes que recebe em relação ao grande investimento que exige a construção de um hotel ou pousada. Dessa forma, surgem, em Coruche, algumas formas de alojamento adequadas aos investidores locais e às demandas dos visitantes regionais, como o autocaravanismo, os alojamentos em casa de moradores das vilas ou fazendas e o turismo de habitação ou aluguel de casas de campo. As fazendas de complexos taurinos abertas à visitação também passaram a ofertar alojamentos característicos do turismo rural. Alojamentos em casa de moradores ou de áreas de lazer poderiam ser uma alternativa para a falta de meios de hospedagem nos pequenos municípios brasileiros que realizam eventos esporádicos de cunho gastronômico, cívico, social e religioso.

A vila, com apenas 9 mil habitantes e sem nenhum hotel, já dispóe de mapa turístico, guia de restaurantes, calendário de eventos e integra rotas de turismo regional, ainda que, na prática, represente apenas local de passagem de turistas.

\section{iii. Óbidos - o Munícipio membro da Rede de Cidades Criativas da UNESCO}

A Vila de Óbidos é conhecida internacionalmente devido aos eventos que realiza por iniciativa da gestão pública, envolvendo diversos agentes locais. Entre eles, merecem destaque a Semana Santa, o Mercado Medieval, o Folio - Festival Literário Internacional de Óbidos -, a Semana Internacional de Piano, o Festival de Ópera, o Maio Criativo, o Junho das Artes, a Temporada de Cravo, o Festival Internacional de Chocolate e a Vila de Natal.

Nesses dois últimos eventos listados, os habitantes da cidade murada de Óbidos recebem aproximadamente 200 mil visitantes (Fidalgo, 2009). Esses 
eventos diversificam-se nos temas abordados e nos públicos que atingem. Os eventos envolvem a comunidade e atraem turistas de lazer, mas também profissionais que vão em busca de conhecimento e qualificação. Para manter sua identidade cultural e artística, a maioria dos eventos realizam, como foco principal ou como atividade paralela, apresentaçôes musicais, culturais e exposiçóes de arte, além de atividades ligadas à educaçáo e às artes, oferecendo desde oficinas de cunho recreativo até cursos de especialização para profissionais. Como exemplo do envolvimento social, a Câmara Municipal cita o evento Maio Criativo, que considera um evento pioneiro ao disseminar a criatividade nos setores formais e informais, da criança ao sênior, envolvendo escolas, associaçóes e o parque tecnológico (Leal, 2013).

Os eventos promovidos pela administração púbica em Óbidos buscam ter algo criativo, um diferencial que não seja replicável em outras localidades. A realização desses eventos busca, mais do que atrair visitantes, estimular o consumo dos produtos e serviços locais, revertendo os benefícios em investimentos locais. Fidalgo (2009, p. 57) verificou que, como geradores de riqueza, esses eventos permitem "ao Município investir na resolução de algumas das suas fragilidades, como a educação, o apoio social a crianças e idosos e as acessibilidades intraconcelhias, e por outro lado apostar em novos eventos". E, ainda, mais do que uma estratégia para receber visitantes em datas específicas, os eventos realizados dão visibilidade ao município, promovendo-o como destino turístico ao longo do ano e atraindo também investidores.

A Câmara Municipal de Óbidos representou papel de agente protagonista do desenvolvimento local ao gerar um ambiente socioeconômico de confiança para investimentos privados, planejar e implementar açôes voltadas à diversificação econômica, bem-estar social, valorização dos recursos locais, estabelecendo relaçôes locais e internacionais. Não só os atrativos turísticos são diversificados, mas toda a economia municipal. Observam-se investimentos, como a criação de parque tecnológico, parque industrial e projetos de irrigação que atingem mais de mil pequenos agricultores.

Suas especialidades, pautadas na identidade, na criatividade, na educação e nas interaçôes locais, permitiram que Óbidos estabelecesse relações mais amplas, participando de redes internacionais de cidades. Entre os exemplos está a relação direta estabelecida entre Óbidos e Gramado, que trocam experiências, especialmente, sobre os festivais de natal e do chocolate e a proteção dos patrimônios culturais e naturais (Leal, 2013). 
Óbidos, devido aos seus investimentos em criatividade, participa em duas importantes redes de cidades. A Rede Internacional Creative Clusters, que integra municípios da Itália, da Romênia, da Espanha, do Reino Unido e da Hungria, e que tem por objetivo encontrar "novas soluçóes e novos actores para rejuvenescer as áreas de baixa densidade" e demonstrar "que a criatividade pode ser o motor do desenvolvimento econômico de pequenos e médios centros urbanos e não apenas das grandes cidades" (Fidalgo, 2009, p. 95). A segunda é a Rede de Cidades Criativas da UNESCO, que reúne outras quatro cidades portuguesas: Óbidos - Cidade Criativa da Literatura (evoluçáo que decorreu do Projeto Vila Literária); Amarante - Cidade Criativa da Música; Barcelos Cidade Criativa do Artesanato e Artes Populares - Braga - Cidade Criativa das Artes e Media; e Idanha-a-Nova - Cidade Criativa da Música.

A influente articulação externa é possível graças ao perfil administrativo, inovador, participativo e com corpo técnico qualificado da Câmara Municipal de Óbidos. Esse perfil é referenciado por meio da criação de empresas municipais específicas para diferentes setores de atuação, que dispóem de maior autonomia e facilidade para estabelecer parcerias. A Óbidos Patrimonium, por exemplo, é uma empresa municipal responsável pela idealização e execução de açóes voltadas para o desenvolvimento do turismo local, que envolve a realização de todos os eventos citados, a promoção turística e a gestão dos espaços turísticos (Disponível em: http://www.obidos.pt/. Acesso em: 26 jun. 2019).

No seu trabalho, Musikyan (2016) apresenta o "Ciclo Criativo de Óbidos", que envolve: os eventos criativos, o turismo criativo, os espaços criativos, a educação criativa, as pessoas criativas e a existência de uma estratégia de desenvolvimento criativo. Para o autor, a conjugaçáo dessas seis componentes confere a Óbidos uma posição estratégica que ultrapassa a escala local.

Essas propostas para o desenvolvimento municipal do turismo apresentam estreitas ligaçóes com documentos orientadores mais amplos, como o Plano Diretor Municipal de Óbidos e o Plano Estratégico Nacional do Turismo de Portugal (Fidalgo, 2009). Os acompanhamentos e os estudos sobre as implicaçóes do turismo no município são indispensáveis instrumentos de gestão. Óbidos realiza açôes de monitoramento não só para ampliar seu público e o alcance de suas açóes, mas também para limitá-los. $\mathrm{O}$ redimensionamento dos objetivos e das metas inclui determinaçóes para controlar o crescimento dos investimentos privados já em andamento, mesmo de capital internacional, como o caso de alguns resorts. 
Óbidos procura, assim, valorizar suas características locais e turísticas de destino ligado à cultura, identidade, tranquilidade e natureza, equacionando, nesse processo, o interesse em manter sua baixa densidade demográfica. Algumas liçốes principais ficam sobre o turismo em Óbidos. Uma lição é que o fato de ter pequeno porte demográfico não impede o desenvolvimento turístico das localidades, bem como o crescimento do turismo náo precisa implicar em crescimento populacional. E a principal lição que fica ao conhecer a realidade do turismo em Óbidos é que ter à disposição recursos naturais e culturais não são suficientes para fazer do turismo uma atividade estratégica ao desenvolvimento local.

Para chegar ao patamar de prestigiado destino turístico da Europa, o município de Óbidos investiu em cultura, conservação ambiental, diversificação econômica e turística, mas principalmente em educação, criatividade, inovação, redes de cooperação e formação de massa crítica, com o objetivo de ter uma sociedade mais atuante.

\section{Considerações finais}

Este trabalho, voltado para o turismo em pequenas localidades, buscou observar as pequenas localidades portuguesas como referenciais para refletir sobre os desafios socioespaciais dos municípios de pequeno porte demográfico. Esses municípios foram, no passado, expressivos centros comerciais e políticos. Contudo, com o passar das décadas, viram seus sistemas econômicos, pautados na atividade agrícola, sofrerem longo período de estagnação e declínio da população. $\mathrm{O}$ turismo se apresenta como uma atividade estratégica ao desenvolvimento local/regional.

Considerando a primeira questão de investigação, verificamos que, nos três municípios em estudo, o turismo assumiu um protagonismo no processo de desenvolvimento desses territórios, caracterizados por perda demográfica e envelhecimento (quadro 4), contribuindo para a diversificação setorial. No caso de Coruche, o percurso vai no sentido de uma valorização da cultura e da identidade local, mas, nos casos de Montemor-o-Novo e de Óbidos, foram mais além, e os caminhos trilhados, que seguem na linha de Richards (2011, 2013), deram lugar ao desenvolvimento de novos produtos e experiências turísticas e contribuíram para a valorização dos ativos culturais e criativos. 
Relativamente à segunda questão de investigação, o papel dos agentes locais, verificamos que o papel do poder público na condução do processo de desenvolvimento parece ter sido a estratégia acertada no caso de Óbidos, onde o turismo tem alcances mais amplos na perspectiva tanto econômica como sociocultural. Os investimentos públicos em educação, cultura, diversificação e inovação são os caminhos para criar uma sociedade crítica e atuante, capaz de determinar seus próprios parâmetros, estratégias e metas de desenvolvimento.

Quadro 4-Síntese dos perfis de desenvolvimento turístico dos três pequenos municípios de Portugal

\begin{tabular}{|c|c|c|c|}
\hline & Montemor-o-Novo & Coruche & Óbidos \\
\hline $\begin{array}{l}\text { Contexto } \\
\text { demográfico }\end{array}$ & $\begin{array}{l}\text { - Declínio populacional } \\
\text { nas últimas décadas e } \\
\text { envelhecimento } \\
\text { - Fraca densidade popu- } \\
\text { lacional e integração } \\
\text { regional em territórios } \\
\text { rurais }\end{array}$ & $\begin{array}{l}\text { - Declínio populacional } \\
\text { nas últimas décadas e } \\
\text { envelhecimento } \\
\text { - Fraca densidade popu- } \\
\text { lacional e integração } \\
\text { regional em territórios } \\
\text { rurais }\end{array}$ & $\begin{array}{l}\text { - Acrescimento popula- } \\
\text { cional e menor grau de } \\
\text { envelhecimento } \\
\text { - Densidade popula- } \\
\text { cional maior que nos } \\
\text { restantes dois muni- } \\
\text { cípios e integração na } \\
\text { rede urbana regional }\end{array}$ \\
\hline Emprego & $\begin{array}{l}\text { - Estrutura de emprego } \\
\text { com peso da atividade } \\
\text { agrícola e do comércio } \\
\text { - Alojamento e res- } \\
\text { tauração com pouca } \\
\text { expressão }\end{array}$ & $\begin{array}{l}\text { - Estrutura de emprego } \\
\text { com peso da atividade } \\
\text { agrícola e do comércio } \\
\text { - Alojamento e res- } \\
\text { tauração com pouca } \\
\text { expressão }\end{array}$ & $\begin{array}{l}\text { - Estrutura de emprego } \\
\text { com peso da atividade } \\
\text { comercial, bem como } \\
\text { forte expressão da res- } \\
\text { tauração }\end{array}$ \\
\hline $\begin{array}{l}\text { Drivers para a } \\
\text { atividade turística }\end{array}$ & $\begin{array}{l}\text { - Patrimônio histórico } \\
\text { e cultural: atividades } \\
\text { no cluster da criativi- } \\
\text { dade e cultura, nome- } \\
\text { adamente desenvol- } \\
\text { vimento artístico, em } \\
\text { áreas como a música, a } \\
\text { dança, a pintura, a lite- } \\
\text { ratura, o artesanato e o } \\
\text { cinema }\end{array}$ & $\begin{array}{l}\text { - Patrimônio cultural } \\
\text { (Gastronomia, Tau- } \\
\text { romaquia e Eventos) }\end{array}$ & $\begin{array}{l}\text { - Patrimônio natural, } \\
\text { histórico-cultural }\end{array}$ \\
\hline
\end{tabular}




\begin{tabular}{|c|c|c|c|}
\hline $\begin{array}{l}\text { Papel do } \\
\text { município }\end{array}$ & $\begin{array}{l}\text { - Atração de agentes e } \\
\text { recursos exógenos } \\
\text { - Existência de uma } \\
\text { agenda cultural muito } \\
\text { forte e incentivo à ati- } \\
\text { vidade }\end{array}$ & $\begin{array}{l}\text { - Aproveitamento de } \\
\text { recursos endógenos } \\
\text { - Existência de uma } \\
\text { agenda cultural muito } \\
\text { dinâmica, tendo em } \\
\text { conta a dimensão do } \\
\text { munícipio, mas a ati- } \\
\text { vidade tem um forte } \\
\text { carácter sazonal }\end{array}$ & $\begin{array}{l}\text { - Aproveitamento de } \\
\text { recursos endógenos } \\
\text { ligados ao setor his- } \\
\text { tórico-cultural, mas } \\
\text { também aos comple- } \\
\text { mentos sol-mar e golf } \\
\text { - Complementaridade } \\
\text { de atividades que ocor- } \\
\text { rem durante todo o ano }\end{array}$ \\
\hline $\begin{array}{l}\text { Instrumentos de } \\
\text { planejamento }\end{array}$ & $\begin{array}{l}\text { - Carta Estratégica de } \\
\text { Desenvolvimento } \\
2025\end{array}$ & $\begin{array}{l}\text { - Plano Estratégico de } \\
\text { Desenvolvimento - } \\
\text { Coruche } 2020\end{array}$ & $\begin{array}{l}\text { - Plano Diretor Muni- } \\
\text { cipal (revisão 2010) e } \\
\text { Membro da Rede de } \\
\text { Cidades Criativas da } \\
\text { Unesco }\end{array}$ \\
\hline
\end{tabular}

\begin{tabular}{llll}
\hline Relevância da & $\bullet$ As atividades assu- & $\bullet$ As atividades assu- & $\bullet$ As atividades assu- \\
atividade & mem relevância para a & mem relevância para & mem relevância para \\
& economia local, regio- & a economia local e & a economia local, \\
& nal e alguma relevân- & regional & regional, nacional e \\
& $\begin{array}{l}\text { cia nacional e interna- } \\
\text { cional de criatividade }\end{array}$ & internacional \\
& cultural & \\
\hline
\end{tabular}

Fonte: Elaboração própria.

Além de Óbidos, outros pequenos municípios portugueses têm o turismo contemplado nos planos de desenvolvimento municipal, além de um plano específico para o desenvolvimento da atividade turística. O turismo está nas agendas do campo público e nas plataformas de campanha, devido ao grande número de pessoas envolvidas com o setor, exigindo atenção para este, influenciando decisóes e demandando gestores qualificados.

Por outro lado, a gestão pública não é o único agente capaz de impulsionar o desenvolvimento do turismo local. Foi observado em Montemor-o-Novo que um único agente exógeno foi capaz de estimular mudanças nas condiçóes de vida de toda a localidade. Em Coruche, observam-se pequenos investimentos locais em serviços turísticos, motivados pelas demandas impostas por visitantes.

As implicaçóes positivas do turismo parecem ser mais evidentes onde há valorização e proteção de atrativos naturais e culturais e onde a gestão do turismo é pautada em planejamento, participação social e investimentos, articulando agentes públicos, privados e a sociedade civil. Com isso, municípios de pequeno porte demográfico, nos atuais processos de redefinição da rede 
urbana, podem ser novas expressóes de centralidade, por meio da oferta de atividades ligadas à criatividade, à cultura e ao turismo.

O triângulo relacional "Cultura-Criatividade-Turismo" assume-se como uma via de promoção da base econômica e social, ao mesmo tempo que potencia a preservação dos valores e das identidades dos lugares, contribuindo para o desenvolvimento dos municípios de pequeno porte demográfico.

\section{Referências}

ALMEIDA, Bernardo. As cidades criativas e a sua importância no desenvolvimento local: Óbidos, uma estratégia de desenvolvimento criativo (dissertação). FCSH, 2018. ANDRÉ, I. e ABREU, A. "Understanding the dynamics of social innovation through arts: the case of Montemor-o-Novo, Portugal". In MOULAERT et al. Social innovation: collective action, social learning and transdisciplinary research. KATARSIS Contract Nr. 029044 (CIT5) WP5 Methodology Development (D5) and Final Report: Towards a Handbook (D6), 2010, p. 60-6.

APRCR. Estratégia de Desenvolvimento Local 2014-2020. Coruche: APRCR, 2015. BARROS, V. G. Turismo em Portugal. Lisboa: Fundação F. Manuel dos Santos, 2015. CÂMARA MUNICIPAL DE CORUCHE. Estratégia de Desenvolvimento $2020 e$ Plano de Aç̧ão 2013 para o concelho de Coruche. Coruche: Câmara Municipal de Coruche, 2009. Turismo. Coruche : Câmara Municipal de Coruche, 2017.

CÂMARA MUNICIPAL DE MONTEMOR-O-NOVO. Atualização da Carta Estratégica - Elementos de Diagnóstico - Relatório de Progresso. Montemor-o-Novo: Câmara Municipal de Montemor-o-Novo, 2015.

CANELAS, Lucinda. "Dez anos e um lugar feliz no Alentejo". Público - Comunicação Social, mai. 2011. Disponível em: https://www.publico.pt/2011/05/28/ jornal/dez-anos-e-um-lugar-feliz-no-alentejo-22158842. Acesso em: $20 \mathrm{dez} .2017$.

CASELLA, A. et al. "Creación de imagen, visibilidad y turismo como estrategias de crecimiento econômico de la ciudad”. Finisterra, v. 45, n. 90, p. 153-72, 2010. Disponível em: https://doi.org/10.18055/Finis1345.

DURMAZ, B. et al. "Creativity, culture tourism and place-making: Istanbul and London film industries". International Journal of Culture, Tourism and Hospitality Research, v. 4, n. 3, 2010.

DUXBURY et al. "Development of rural areas and small cities through creative tourism: the CREATOUR project". Rev. Anais Bras. de Est. Tur., v. 8, n. 3, p.7484, set.-dez 2018. 
ENDLICH, Ângela Maria. Pensando os papéis e significados das pequenas cidades do noroeste do Paraná (tese). Universidade Estadual Paulista Júlio de Mesquita Filho, 2006.

. "Resenha de ROQUES, Jean-Luc. Une sociologie de la petite ville". Biblio 3W, Revista Bibliográfica de Geografia.. Barcelona, v. 18, n. 1.050, 25 nov. 2013.

. "Na trilha conceitual e de definiçôes das pequenas cidades". In BOVO, M. C. e COSTA, F. R. (orgs.). Estudos urbanos: conceitos, definiçóes e debates. Campo Mourão: Fecilcam:Unespar, v. 1, p. 33-53.

FERNANDES, R. et al. "Novas oportunidades para os espaços urbanos de pequena e média dimensão: a centralidade das atividades culturais e criativas no quadro da especialização inteligente”. Actas VII Congresso Luso Brasileiro para o Planejamento Urbano, Regional Integrado e Sustentável: Contrastes, Contradiçôes e Complexidades. Pluris, 2016.

FIDALGO, S. S. Marketing Territorial de Desenvolvimento das Populaçóes: a paisagem cultural de Óbidos (dissertação). Un. Coimbra, 2009.

FLORIDA, Richard. Entrepreneurship, creativity, and regional development. Carnegie Mellon University, 2002.

GOMES, C. S. "O turismo como via de engrandecimento para cidades: dilemas e estratégias de desenvolvimento de quatro cidades médias da Península Ibérica". Atas do VII Congresso Português de Sociologia: Sociedade, Crise e Reconfiguraçôes. Porto: Un. Porto - F. Letras, 2012.

GOULART, Ana. "Espaço do Tempo - Montemor-o-Novo acolhe artes performativas”. Searanova-Cultura, n. 1.712, 2010. Disponível em: http://www.searanova. publ.pt/pt/1712/cultura/168/. Acesso em: 20 dez. 2017.

INTELI. Creative-based strategies in Small and Medium-sized cities: Guidelines for local authorities. Óbidos: Câmara Municipal de Óbidos, 2011.

LANDRY, Charles. Creativity, culture \& the city: a question of interconnection. Ministry of Family, Children, Youth, Culture and Sport of the State of North Rhine - Westphalia, 2010.

LARANJEIRA, A. S. B. Abordagem morfológica no estudo de aglomerados urbanos. Caso de estudo: Montemor-o-Novo (dissertação). Universidade Técnica de Lisboa, 2011.

LEAL, L. C. Fábrica de Criatividade de Óbidos: estudo exploratório e percepçóes sociais (dissertação). Un. Aberta, 2013.

MARQUES DA COSTA, Eduarda. "Cidades médias: contributos para a sua definição". Revista Finisterra, v. 37, n. 74, p. 101-28, Universidade de Lisboa, 2002.

"As pequenas e médias cidades portuguesas - dinâmicas demográficas e funcionais nos últimos quarenta anos". In MATURANA, F. et al. (eds.). Sistemas urbanos y ciudades medias en Iberoamérica. Santiago: Pontificia Universidad Católica de Chile, 2017, p. 258-300. (Serie GEOlibros). 
MARUJO, N. "A cultura, o turismo e o turista: que relação?". TURyDES, Revista de Turismo y Desarrollo, v. 6, n. 15, p. 1-12, 2014.

MATEUS, Augusto (coord.). O sector cultural e criativo em Portugal. Estudo para o Ministério da Cultura, Gabinete de Planeamento, Estratégia, Avaliação e Relações Internacionais. Lisboa: Augusto Mateus \& Associados - Sociedade de Consultores, 2010.

MUSIKYAN, Srbuhi. The influence of creative tourismo on sustainable development of tourism and reduction of seasonality: case study of Óbidos (tese). Leiria: Escola Superior de Turismo e Tecnologia do Mar, 2016.

O ESPAÇO DO TEMPO. "Projetos Estruturantes Montemor-o-Novo", 2017. Disponível em: http:// http://www.oespacodotempo.pt/pt/o-espaco-do-tempo. Acesso em: 03 dez. 2017.

OECD. The impact of culture on tourism. Secretary-General of the OECD, 2009.

PARREIRA, C. J. V. Animação turística no Alentejo: sobre a oportunidade para criar um serviço aeronáutico inovador (dissertação). Universidade de Évora, 2015.

PEREIRA, L. F. M. Tauromaquia: identidade cultural, enquadramento legal e desenvolvimento. (dissertação) ISCTE, 2010.

PRATT, A. "Creative cities". Urban Design Journal, v. 106, p. 35, 2008.

RICHARDS, G. Cultural attractions and European tourism. CABI, Wallingford, 2001. (ed.). Cultural tourism: global and local perspectives. Nova York: Haworth Press, 2007.

. "Tourism development trajectories - from culture to creativity?". Tourism \& Management Studies, n. 6, p. 6-15, 2009.

. "Creativity and tourism: the state of the art". Annals of Tourism Research, v. 38, n. 4, p. 1.225-53, 2011.

. "Creativity and tourism in the city". Current Issues in Tourism, 2013. Disponível em: http://dx.doi.org/10.1080/13683500.2013.783794.

e WILSON, J. "Developing creativity in tourist experiences: a solution to the serial reproduction of culture?". Tourism Management, v. 27, Issue 6, dez. 2006, p. 1.209-23. Disponível em: https://doi.org/10.1016/j. tourman.2005.06.002.

SELADA, Catarina et al. "Creative-based strategies in small cities: a case study approach". Redige, v. 2, n. 2, 2011. 



\section{Capítulo 6 \\ Política urbana no Brasil: \\ a difícil regulação de uma urbanização periférica}

Angela Moulin S. Penalva Santos

\section{Introdução}

Foi somente em 1938, por meio do Decreto Lei 31, que o governo federal estabeleceu a distinção entre território urbano e rural, oportunidade em que, tratando os municípios então estabelecidos, passou a considerar o território urbano como aquele que se constituía pela população residente em sedes municipais ou de distritos, independentemente de sua função na rede urbana ou do tamanho de sua população.

Esse início do tratamento normativo do território urbano coincide com o processo de industrialização brasileiro, num contexto de crise da economia primário-exportadora. A emergência de uma sociedade de base urbano-industrial alterou a natureza da relação entre o rural e o urbano. Antes desse período, as cidades eram face urbana da agroexportaçáo, mas a industrialização tornaria a cidade o locus do capitalismo, o que levou a um intenso processo de migração rural-urbana.

A acelerada urbanização no país não foi acompanhada de políticas públicas adequadas para regular o crescimento das cidades, que experimentaram um processo de expansão urbana periférica. Em consequência, a dinâmica econômica prevaleceu sobre o ordenamento urbano e levou à formação de áreas metropolitanas, nas quais problemas socioambientais emergiram, demandando respostas do poder público. 
Neste capítulo, explora-se a difícil regulação do processo de urbanização brasileiro ao longo do século XX e os desafios que emergem no século XXI. Além da introdução, o capítulo está constituído de mais três seçóes. Na primeira, sintetiza-se o processo de urbanização no Brasil, visando a associar a transformação de uma sociedade rural em outra de base urbano-industrial; na segunda, o objetivo é destacar o avanço na legislação urbanística introduzida no período pós-constitucional, marcado por um aumento dos direitos sociais no país; na terceira, analisa-se a persistência da urbanização periférica, característica do processo de urbanizaçáo brasileiro, o que permite situar o fracasso do avanço normativo das políticas urbanas em ter efetividade em prol de uma urbanização social e inclusiva da população pobre.

\section{O processo de urbanização no Brasil}

No último século, a população brasileira cresceu de 17 milhóes para 170 milhôes de habitantes. No início do século XX, apenas 17\% dessa população vivia em cidades, situação que se inverteu no fim do século, quando esse percentual já era de $81 \%$, elevando-se ainda mais no último censo demográfico, realizado em 2010, que apurou uma taxa de urbanização de $84 \%$. Tamanha mudança demográfica está associada à passagem da dinâmica econômica de base primária e exportadora para uma de base urbano-industrial.

O processo brasileiro de industrialização intensificou-se após 1930, quando a crise da agroexportação desestruturou a atividade rural e liberou a força de trabalho, a qual, assim, passou a buscar na cidade novas oportunidades de emprego. A partir de então, formaram-se áreas metropolitanas nucleadas pelas capitais estaduais, tendo São Paulo e Rio de Janeiro como as mais importantes, nas quais apenas as capitais estaduais respondem por $11 \%$ e 5\%, respectivamente, do PIB brasileiro em 2015 (IBGE, 2017).

Entre 1930 e 1980, a economia brasileira cresceu dinamizada pela Indústria, o que se fez acompanhar pelas migraçóes rural-urbanas. Houve forte diminuição do peso demográfico da população rural, com a concentração da população na regiáo Sudeste, o epicentro da economia industrial. Mas, dentro de cada macrorregião, também se manifestou o processo de concentração em torno das capitais estaduais. Portanto, a população brasileira experimentou uma intensificação de sua taxa de urbanização, com concentração nas maio- 
res cidades. A tabela a seguir apresenta a evolução demográfica no país, no período 1970-2010.

Figura 1 - Evolução da população e taxa de urbanização no Brasil, 1970-2010

\begin{tabular}{lccc}
\hline Anos & $\begin{array}{c}\text { Populaçáo Total } \\
(\mathbf{A})\end{array}$ & $\begin{array}{c}\text { Populaçáo } \\
\text { Urbana }(\mathbf{B})\end{array}$ & (B)/(A)\% \\
\hline 1970 & 93.134 .846 & 52.097 .269 & 55,94 \\
\hline 1980 & 119.011 .052 & 80.437 .327 & 67,59 \\
\hline 1990 & 146.825 .475 & 110.990 .990 & 75,59 \\
\hline 2000 & 169.799 .170 & 137.953 .959 & 81,25 \\
\hline
\end{tabular}

Fonte: Censos Demográficos, IBGE.

Desde a década de 1980, a Indústria vem perdendo peso na formação do PIB, ainda que a polarização espacial se tenha mantido. As grandes cidades se tornaram economias de serviços num contexto em que as novas tecnologias de informação, conjugadas a uma nova divisão social do trabalho, sustentaram a atração locacional dos grandes centros.

Os defensores das grandes cidades as veem como locais que favorecem a diversidade (Jacobs, 2003), que comandam espaços de fluxos (Castells, 1999) e que estimulam a inovação por meio da disseminação do conhecimento tácito que é produzido por seus residentes e, principalmente, por seus laboratórios de pesquisa (Storper e Venables, 2005; Glaeser, 2011). O principal atributo dessas cidades seria sua capacidade de reunir a população com elevados níveis de escolaridade, interagindo e produzindo novidades. A força econômica desses grandes aglomerados seria o burburinho, como apontado por Storper e Veneables (2005), que favorece a diversidade, além dos ganhos de escala associados a economias de escopo.

Tamanha força econômica, por sua vez, traduz-se em elevada participação dessas cidades na distribuição espacial das oportunidades de trabalho, que estariam relacionadas à dinâmica atual do capitalismo contemporâneo. Segundo a teoria urbana, o processo de globalização tem contribuído para modificar de que modo se estrutura o território desde que as finanças sucederam a indústria como atividade dominante (Castells, 1999; Sasken, 2003; Hall, 2004; Harvey, 2011). O resultado tem sido o fortalecimento - e não o enfraquecimento - das 
metrópoles, que se tornaram pontos essenciais na economia contemporânea, tendo em vista a concentração de serviços especializados e de grande porte, os quais permitiriam a conexão com outras metrópoles num mundo cada vez mais interdependente. Trata-se daquilo que Milton Santos (1996) denominou "meio técnico" adequado à acumulação capitalista disponível nas grandes áreas urbanas.

Essa marcada polarização espacial vem sendo experimentada no Brasil. Segundo o Censo Demográfico de 2010, a população brasileira atingiu 191 milhôes de habitantes, dos quais 54,75\% residiam em apenas 283 dentre os 5.570 municípios brasileiros. Esses 283 são os municípios com mais de 100 mil habitantes, dos quais 27 são capitais estaduais, e os demais estão em seu entorno (cidades metropolitanas) ou em áreas fora das regióes metropolitanas (cidades não metropolitanas).

Figura 2 - Participação das maiores cidades na população e PIB brasileiros (2000 e 2010)

\begin{tabular}{lcccc}
\hline Cidades & $\begin{array}{c}\text { População } \\
(\mathbf{2 0 0 0})\end{array}$ & PIB (2000) & $\begin{array}{c}\text { População } \\
(\mathbf{2 0 1 0})\end{array}$ & PIB (2010) \\
\hline Capitais estaduais & 22,54 & 37,06 & 23,83 & 34,03 \\
\hline $\begin{array}{l}\text { Cidades } \\
\text { metropolitanas }\end{array}$ & 15,61 & 18,94 & 15,95 & 19,13 \\
\hline $\begin{array}{l}\text { Cidades não } \\
\text { metropolitanas }\end{array}$ & 14,47 & 16,33 & 14,91 & 17,13 \\
\hline Média & 52,61 & 72,33 & 54,69 & 70,30 \\
\hline Brasil & $100 \%$ & $100 \%$ & $100 \%$ & $100 \%$ \\
\hline
\end{tabular}

Fonte: Elaboração própria com dados do IBGE: Censos Demográficos de 2000 e 2010 e Contas Nacionais.

Na primeira década do século XXI, o já elevado peso desse grupo de apenas $5 \%$ do número de municípios brasileiros experimentou crescimento em seu peso demográfico, mas não no PIB. No entanto, a perda de participação percentual de 72,33\% para 70,30\% é muito incipiente em comparação à grandeza dessa participação. Esse resultado explica por que esses municípios seguem oferecendo 3 a cada 4 empregos (saldo líquido entre admissões e demissões) na referida década (CAGED, 2000 e 2010).

A segunda década do século XXI tem sido marcada por forte crise econômica, que se manifestou em queda no PIB brasileiro a partir de 2014, destacando-se o biênio 2015/2016 quando a perda alcançou -3,8\% e -3,6\%, 
respectivamente. Tamanho declínio afeta mais fortemente a economia dessas grandes cidades, dada a queda na arrecadação tributária, enquanto as cidades de menor porte foram socorridas em seus orçamentos pelo aumento de transferências intergovernamentais (Santos, 2018).

A crise só não foi mais forte devido ao dinamismo do agronegócio, sustentando exportaçóes. Em tal contexto, é possível que tenha diminuído os pesos demográfico e econômico dessas grandes cidades e possa ter havido alguma redistribuição espacial da população. Entretanto, dificilmente terá alimentado o crescimento das pequenas cidades. Muito provavelmente terá se refletido no aumento do peso de cidades de médio porte, particularmente daquelas situadas em áreas produtoras de commoditties primárias. Porém tal hipótese só poderá ser avaliada após a realização do Censo Demográfico de 2020, previsto para setembro deste ano.

As políticas públicas urbanas representam a forma pela qual o Estado se estrutura para ordenar o espaço urbano. Desde a década de 1930, a migração rural-urbana desafia o poder público no sentido de aumentar a provisão de acesso aos meios de consumo coletivo, como a infraestrutura urbana e social. Essa provisão dependeu da competição por alocação de verbas no orçamento com os demais gastos públicos, ganhando maior prioridade apenas quando os efeitos negativos da falta de desenvolvimento urbano se tornaram graves, o que, inclusive, suscitou diversos movimentos sociais voltados à temática urbana, a partir da década de 1960, momento em que a população urbana ultrapassou a rural.

\section{Como é a regulação normativa da urbanização brasileira?}

Se a polarização espacial está disseminada pela maioria dos países, a forma como cada poder público enfrenta essa questão varia muito. No caso brasileiro, as políticas públicas urbanas experimentaram uma fase inicial em que prevaleceu uma "não política", ou seja, o Estado negligenciou os problemas associados à urbanização. Essa realidade seria modificada após 1964, quando um regime autoritário foi instituído e muitas reformas institucionais foram realizadas, incluindo a introdução de políticas urbanas e o reconhecimento legal de nove regióes metropolitanas. Essa etapa se esgota com o retorno da ordem democrática, em 1985, seguida da entrada em vigor de uma nova Constituição, em 1988, que pode ser considerada um ponto de inflexão na regulação urbanística do país. 


\section{Política urbana no Brasil antes da Constituição de 1988}

A partir de 1930, a intensificação da urbanização, com a consolidação das primeiras metrópoles brasileiras, levou a iniciativas do poder público para enfrentar os problemas urbanos. Algumas importantes reformas foram introduzidas nos cenários político e econômico, mas não houve um tratamento institucionalizado da questão urbana, o que foi considerado uma não política (Cintra, 1978). Ainda assim, cabe mencionar a legislação que dificultava a retomada de imóveis para aluguel, justificada como medida para enfrentar o aumento dos valores locatícios, em um contexto de crescente disputa pela terra urbana. Como resultado, houve diminuição do investimento voltado à construção imobiliária, e isso repercutiu na falta de moradia, o que levou a soluções informais de autoconstrução - as quais, em muitos casos, ocuparam áreas públicas e consideradas não edificáveis pela legislação vigente.

O resultado dessa "não política", ou omissão do poder público diante dos desafios da urbanização crescente, foi a produção da "cidade ilegal", aquela que não era reconhecida como parte das cidades, ainda que fosse uma realidade fática. $\mathrm{O}$ não reconhecimento dessa produção informal impedia a execução de políticas públicas que incorporassem essas áreas na política de urbanização da cidade formal.

A informalidade na produção da cidade inclui a formação de favelas, ou seja, aglomerados urbanos irregulares tanto em termos fundiários como em termos urbanísticos, mas também loteamentos irregulares. Estes últimos, em geral, são irregulares em termos urbanísticos, ainda que muitos se refiram a imóveis que têm a propriedade fundiária reconhecida.

As favelas surgiram no início do século XX, na então capital do país, a cidade do Rio de Janeiro. A abolição da escravatura e algumas obras públicas de forte impacto urbanístico levaram os pobres a buscarem moradias na encosta de morros, com a intenção de se manterem próximos aos polos de emprego concentrados no centro da cidade. Essa alternativa de moradia foi a possibilidade encontrada num contexto em que o poder público náo investia em políticas habitacionais e de mobilidade urbana. Assim, em 1950, 7\% da população do Rio de Janeiro vivia em favelas, percentual que seguiu se elevando, vindo a atingir 22\% dos habitantes no fim do século XX. De acordo com os últimos dados censitários, em 2010, aproximadamente 11,4 milhóes de pessoas (6\% da população) viviam em aglomerados subnormais, termo técnico que o IBGE 
utiliza para denominar as favelas. Em todo o país foram identificadas 6.329 favelas localizadas em 323 dentre os 5.565 municípios brasileiros entáo instalados. A favelização é, portanto, um problema presente num grupo pequeno de cidades, naquelas de médio e grande porte demográfico.

De acordo com os resultados censitários de 2010, as capitais estaduais com maior proporção de habitantes que moram em favelas são Belém, que tem mais da metade da populaçáo $(53,9 \%)$ vivendo nesse tipo de aglomeração, seguida por Salvador (26,1\%), São Luís $(24,5 \%)$ e Recife $(23,2 \%)$. As duas maiores cidades do país, São Paulo e Rio de Janeiro, têm 11\% e 22\% da população morando em favelas, respectivamente. Apesar desse percentual menor, é nessas duas cidades que se encontra o maior número absoluto de pessoas faveladas: 2.162.368 em São Paulo e 1.702.073 no Rio de Janeiro.

Os loteamentos resultam da mudança do uso da terra rural nas franjas urbanas para uso residencial. À medida que as migrações rural-urbanas foram se acentuando, alinhadas com o processo de industrialização e com a manutenção de uma estrutura fundiária muito concentrada, ocorreu a expansão urbana por loteamentos irregulares. Assim, houve crescimento extensivo das cidades, com a expansão mais acentuada nas periferias. O poder público, então, tentou ordenar os loteamentos urbanos por meio da edição de uma lei federal (Lei 6.766/79). Trata-se, contudo, de uma legislação muito restritiva, que prevê inúmeras obrigações aos loteadores, onerando significativamente o empreendimento imobiliário, o que inviabiliza financeiramente aqueles voltados à moradia popular (Botelho, 2007; Costa, 2001).

Apesar disso, no entanto, o reconhecimento legal da promessa de compra e venda dos lotes estimulou a disseminação dos loteamentos irregulares destinados à população de baixa renda, na expectativa de que os adquirentes constituíssem força política suficiente para levar o poder público a urbanizar a área loteada, responsabilidade que deveria ser atendida pelos loteadores. Como resultado, houve a realimentação - e não a mitigação - da desordem urbana, o que agravou a crise nas cidades. Em 2001, uma pesquisa do IBGE sobre o perfil da gestáo municipal no Brasil identificou a presença de loteamentos irregulares em 48\% dos municípios. Esse resultado sugere que os loteamentos irregulares proliferaram não apenas nas cidades de médio e grande portes, mas também nos municípios pequenos.

O desafio da forte urbanização da população foi um problema que mereceu enfrentamento pelas políticas públicas após a ruptura institucional ocorrida em 1964. Na década de 1960, foram criados o Serviço Federal de 
Habitação e Urbanismo (SERFHAU) e o órgão financeiro que cuidaria de executar as políticas, o Banco Nacional de Habitação $(\mathrm{BNH})$, responsável não só pelo financiamento da construção habitacional, mas também pela gestão da política de saneamento, instituída pelo Plano Nacional de Saneamento (PLANASA).

A importância do BNH pode ser inferida pelo balanço de sua contribuição ao mercado imobiliário brasileiro: até a sua extinção, em 1986, o banco foi responsável pelo financiamento de $24 \%$ das unidades habitacionais construídas no país. Responsabilizou-se, ademais, pela expansão da cobertura de esgotamento sanitário, transferindo para as companhias estaduais de água e saneamento os recursos com os quais elas financiaram as obras.

Nas décadas de 1960 e 1970, o governo militar usou a malha urbana para articular o território brasileiro, investindo na implantação de um conjunto de redes: viária, de energia e de comunicação (Becker e Egler, 1993). Ademais, reconheceu as metrópoles como territórios que mereciam um tratamento específico, diferente da política municipal, o que levou à institucionalização de nove regióes metropolitanas, responsáveis pela articulação dos serviços públicos no território.

Trata-se de um período (1964-1985) que testemunhou importantes avanços na política urbana, embora ainda muito associados à reorganização do espaço em função das necessidades da industrialização (Monte-Mór, 2005). Assim, por exemplo, as cidades passariam a receber muitas obras viárias, consideradas necessárias para adaptá-las ao uso do automóvel, cuja indústria foi um dos sustentáculos do processo industrial no país. O financiamento dessas obras era assegurado pela criação de um fundo com recursos vinculados a obras viárias: o Fundo Rodoviário Nacional.

Tal como ocorre em todas as reformas urbanas, alguns problemas foram enfrentados, mas logo emergiram outros, como, por exemplo, os derivados da insustentabilidade ambiental da urbanização extensiva. Questôes ainda pendentes de tratamento adequado, caso do saneamento, somaram-se às questóes de mobilidade urbana e segurança pública. Em consequência, a deterioração das condiçóes de vida, especialmente daquela população residente na cidade informal, demandou crescente financiamento para o investimento em serviços públicos. Nesse contexto, reemergiram os movimentos sociais, dentre os quais se destaca o Movimento Nacional pela Reforma Urbana, muito ativo 
nas décadas de 1970 e 1980, tendo sido responsável pela introdução de um capítulo sobre política urbana na Constituição da República de 1988.

\section{Os avanços normativos pós-Constituição de 1988}

A Constituição de 1988 inaugurou uma nova abordagem para a questão urbana. A partir de então, esta deixou de ser entendida como modernização do espaço urbano dentro do processo de industrialização e passou a se identificar com o direito à cidade. Além de elevar o município à condição de ente federativo, a Constituição incluiu dois importantes artigos, alinhando a política urbana como responsabilidade municipal (art. 182) e simplificando a regularização fundiária urbana ao definir em cinco anos o tempo de posse mansa da terra, ou seja, a posse náo conflituosa, para fins de usucapião (art. 183).

A regularização fundiária foi um dos mais relevantes instrumentos para o ordenamento das cidades. Dado o crescimento da população que residia em favelas e em loteamentos irregulares, foi preciso contornar a informalidade desse tipo de ocupação com a criação das chamadas "zonas (ou áreas) especiais de interesse social”. Ao definir o contorno territorial dessas zonas, a legislação municipal tornou possível a identificação de localidades em que as exigências da legislação urbanística seriam especiais, o que permitiria regularizar urbanisticamente comunidades inteiras. Essa estratégia foi um passo importante para que deixasse de ser regra a política de remoção de tais comunidades. Ao contrário, elas passaram a receber investimentos públicos, com projetos de urbanização de favelas, a exemplo do Programa Favela-Bairro, no município do Rio de Janeiro, durante a década de 1990 .

No artigo 182, declara-se o município como responsável pela política urbana, sendo que aqueles com população superior a 20 mil habitantes são obrigados a elaborar o seu Plano Diretor, considerado instrumento básico para a política de desenvolvimento e expansão urbana. A propriedade urbana deixa de ser considerada absoluta, já que precisa cumprir sua função social, entendida como aquela que atende às exigências de ordenação da cidade no Plano Diretor. Ademais, permite que o poder público municipal, mediante lei específica para área incluída no Plano Diretor, exija do proprietário do solo urbano não edificado, subutilizado ou não utilizado, seu aproveitamento adequado.

Ainda que o município seja o ente federativo responsável pela política urbana, o governo federal editou uma série de leis que regulamentaram avanços 
normativos instituídos pela Constituição. Uma síntese de cada uma dessas leis é apresentada a seguir.

\section{i. Lei do Estatuto da Cidade}

A maior parte dos novos instrumentos jurídicos criados para regular o adequado aproveitamento da terra urbana só passaria a ter efetividade após a lei federal que regulamentou os dois artigos constitucionais, a Lei 10.257/2001, denominada Estatuto da Cidade. O novo tratamento do direito de propriedade gerou muita resistência política, motivo pelo qual a referida lei somente seria aprovada 13 anos depois da promulgação da Constituição.

A lei define que a política urbana tem por objetivo ordenar o pleno desenvolvimento das funçóes sociais da cidade e da propriedade urbana mediante algumas diretrizes, com destaque para: i) garantia do direito a cidades sustentáveis, entendido como o direito à terra urbana, à moradia, ao saneamento ambiental, à infraestrutura urbana, ao transporte e aos serviços públicos, ao trabalho e ao lazer, para as geraçôes presentes e futuras; ii) gestão democrática da cidade; e iii) cooperação entre os governos, a iniciativa privada e os demais setores da sociedade no processo de urbanização, em atendimento ao interesse social.

No que tange à diretriz relacionada à ordenação e ao controle do uso do solo, a lei estabelece muitos objetivos. É preciso evitar, principalmente: a utilização inadequada dos imóveis urbanos; o parcelamento do solo, a edificação ou o uso excessivo ou inadequado em relação à infraestrutura urbana; e a retenção especulativa de imóvel urbano que resulte em subutilização ou não utilização. Outras diretrizes que merecem destaque referem-se a: justa distribuição dos benefícios e ônus decorrentes do processo de urbanização; adequação dos instrumentos de política econômica, tributária e financeira e dos gastos públicos aos objetivos do desenvolvimento urbano, de modo a privilegiar os investimentos geradores de bem-estar geral e a fruição dos bens pelos diferentes segmentos sociais; regularização fundiária e urbanização das áreas ocupadas por população de baixa renda, mediante o estabelecimento de normas especiais de urbanização, uso e ocupação do solo e edificação, levando-se em consideração a situação socioeconômica da população e as normas ambientais.

Para alcançar esses objetivos, foram introduzidos instrumentos gerais de política urbana, como a obrigatoriedade do plano diretor e sua articulação com os instrumentos de planejamento para a administraçáo pública - por exemplo, os planos plurianuais e de investimento a cada quatro anos, a lei 
anual de diretrizes orçamentárias e a lei orçamentária anual. Mas foram os novos instrumentos jurídicos que causaram maior impacto na gestão do território urbano. Tais instrumentos incluem: i) parcelamento, edificação ou utilização compulsórios; ii) concessão de uso especial para fins de moradia; iii) direito de superfície; iv) outorga onerosa do direito de construir; v) operaçóes urbanas consorciadas; e vi) transferência do direito de construir, entre os mais importantes. Cada um desses novos instrumentos deve ter uma lei municipal que regule sua utilização no território do município, o que esvazia de conteúdo o instrumento que, embora incluído no Estatuto da Cidade, não conte com regulamentação municipal.

Cabe destacar que o Plano Diretor somente é obrigatório no caso dos municípios que contem com mais de 20 mil habitantes ou que façam parte de regiôes metropolitanas, além dos demais casos estabelecidos no art. 41 do Estatuto da Cidade. Isso significa dizer que a maior parte dos municípios brasileiros está desobrigada de elaborar o principal instrumento de ordenamento urbanístico, como se infere da tabela a seguir, que apresenta a distribuição dos municípios segundo classes de tamanho de sua população.

Figura 3 - Distribuição dos municípios brasileiros segundo as classes de tamanho da população e o respectivo peso na população brasileira, 2010

\begin{tabular}{lcc}
\hline $\begin{array}{l}\text { Municípios/anos (1.000 } \\
\text { habitantes) }\end{array}$ & $\begin{array}{c}\text { Número de municípios } \\
(\mathbf{2 0 1 0 )}\end{array}$ & $\begin{array}{c}\text { Peso percentual na } \\
\text { população brasileira (\%) }\end{array}$ \\
\hline$<20$ & 3.914 & 17,1 \\
\hline Entre 20 e 50 & 1.043 & 16,4 \\
\hline Entre 50 e 100 & 325 & 11,7 \\
\hline Entre 100 e 250 & 184 & 14,5 \\
\hline Entre 250 e 500 & 61 & 11,0 \\
\hline Entre 500 e 2.000 & 32 & 14,8 \\
\hline$>2.000$ & 6 & 14,5 \\
\hline Total & 5.565 & 100,0 \\
\hline
\end{tabular}

Fonte: Censo Demográfico 2010, IBGE.

Ainda que o município seja o responsável pela política urbana mediante a elaboração de seu plano diretor, o Estatuto da Cidade atribui algumas responsabilidades à Uniāo. O governo federal deve editar normas gerais, em especial 
as relativas à cooperação interfederativa e às diretrizes de desenvolvimento urbano, incluindo habitação, saneamento e transporte urbano.

Tais normas gerais foram editadas após uma importante inovação na estrutura do poder público no que concerne à política urbana: em 2003, foi criado o Ministério das Cidades, responsável pela tentativa de coordenar as políticas setoriais com impacto no processo de desenvolvimento urbano.

Cabe destacar que as três esferas de governo devem elaborar planos de ordenação do território em escala nacional (União), regional (estados) e local (municípios). As competências federal e municipal estão bem delimitadas, enquanto, no caso dos estados, a competência é residual. Ainda assim, os estados ficaram responsáveis pelas normas relativas às regióes metropolitanas já existentes desde 1973, instituídas pela Lei Complementar n. ${ }^{\circ}$ 14. O resultado foi a transformação da política urbana em uma arena da política dominada pelo governo federal e os municipais.

\section{ii. Lei dos Consórcios Públicos}

A Lei 11.107/2005 regulamentou a contratação de consórcios públicos, os quais passaram a ter personalidade jurídica, sendo objeto de contrato, o que torna mais difícil que uma das partes o abandone. Já existiam consórcios, especialmente aqueles que reuniam alguns municípios para a execução de políticas que requerem uma escala superior à da maioria dos municípios brasileiros de pequeno porte demográfico, caso do saneamento básico.

Desde a sua regulamentação, em 2007, os consórcios intermunicipais têm sido mais frequentes nas políticas de saneamento e saúde. Têm sido mais frequentes também entre os municípios pequenos e, em especial, entre aqueles de porte demográfico semelhante. Nos demais casos que envolvem um município maior que seus vizinhos, observa-se resistência na formação de consórcios em razão do desequilíbrio de poder exercido pelo município principal. Justamente nesses casos é que se mostra necessária a coordenação dos governos estaduais, ainda muito incipientes. 


\section{iii. Lei do Sistema Nacional de Habitação e Interesse Social}

Ainda no ano de 2005, entrou em vigor a Lei 11.124, que instituiu o Sistema Nacional de Habitação de Interesse Social (SNHIS). Essa lei federal inaugurou uma nova política habitacional ao reconhecer que apenas regular o mercado imobiliário náo seria suficiente para ampliar a cobertura da população com acesso ao direito social à moradia. Era necessário subsidiar parte da produção da moradia voltada à população de baixa renda.

Pesquisa realizada sobre o déficit habitacional brasileiro identificou que as famílias com renda inferior ao equivalente a 3 salários mínimos correspondem a 90\% do total (FJP, 2013). O déficit não é constituído apenas por novas moradias a serem construídas, mas também por aquelas consideradas inadequadas. A inadequação pode ser aferida pela falta de acesso à infraestrutura (acesso à rede geral de abastecimento de água, à rede geral de esgoto e à coleta de lixo) ou pelo peso de seu custo na renda das famílias (gasto superior a $30 \%$ da renda familiar com aluguel, muitos moradores por quarto ou mais de uma família coabitando o mesmo domicílio). Assim, o déficit habitacional pode ser enfrentado mediante: i) construção de novas moradias; ii) expansão da rede de infraestrutura urbana para incluir todos os domicílios permanentes; e iii) controle do preço da terra urbana para não onerar demasiadamente as famílias de baixa renda (rendimento inferior a 3 salários mínimos).

Os municípios contam com instrumentos urbanísticos e jurídicos para induzir o uso social da propriedade urbana, mas não têm autonomia orçamentária para enfrentar um programa de construção de moradia social em larga escala. Por isso, o governo federal instituiu a Política Nacional de Habitação de Interesse Social, a ser financiada com recursos federais. Para executá-la, estados e municípios precisam aderir ao SNHIS, cumprindo três obrigaçóes: i) criar um fundo específico para gerir as receitas; ii) instituir os conselhos gestores desse fundo; e iii) aprovar seus planos de habitação - Plano Estadual de Habitação de Interesse Social (PEHIS) e Plano Local de Habitação de Interesse Social (PLHIS). Trata-se de um modelo de adesão no âmbito da política federal alinhado com a responsabilidade compartilhada entre os três entes federativos.

Para executar a política local de habitação de interesse social foi criado o Programa Minha Casa Minha Vida (PMCMV) pela Lei 11.977/2009. Suas metas iniciais se constituíam em: i) construir 1 milhão de moradias destinadas 
às famílias com renda de até 10 salários mínimos, além de antecipar outros instrumentos e ações previstos no Plano Nacional de Habitação, como a distribuição dos recursos de acordo com o déficit; ii) regionalizar o custo dos imóveis; iii) contar com a contrapartida dos entes federativos; e iv) desempenhar papel significativo na regularização fundiária visando a complementar $\mathrm{o}$ acesso à moradia.

A subvenção econômica é limitada à faixa de 6 salários mínimos, podendo ser acumulada com subsídios dos estados e dos municípios, sendo que as famílias com até 3 salários mínimos recebem subsídio integral. Os adquirentes cuja renda familiar situa-se entre 6 e 10 salários mínimos beneficiam-se com a redução dos custos do seguro e o acesso ao fundo garantidor (garantia de pagamento aos agentes financeiros da prestação mensal do financiamento). Os recursos são destinados exclusivamente à produção ou à aquisição de novas unidades habitacionais nas áreas urbanas ou à requalificação de imóveis já existentes nas áreas já consolidadas.

\section{iv. Lei do Saneamento Ambiental e Resíduos Sólidos}

A Lei 11.445/2007 estabelece as diretrizes nacionais para o saneamento básico e resíduos sólidos. A entrada em vigor dessa norma permitiu que o arcabouço normativo brasileiro passasse não só a contar com conceitos jurídicos importantes, como saneamento básico ou universalização do saneamento, mas também tratou de organizar a atuação dos entes federativos no que tange à implementação das políticas públicas em questão.

Embora seja possível identificar evidente preocupação social na implementação dos sistemas de saneamento e fornecimento de água, boa parte do mencionado instrumento normativo está concentrada em criar um marco regulatório claro para as respectivas questôes operacionais da política pública, especialmente no que se refere à forma de concessão e definição de tarifas.

Como em outras políticas públicas, o Município recebeu obrigaçôes de natureza executiva. Cabe lembrar, todavia, que parte expressiva dos recursos públicos virão da União, como no caso da Política Nacional de Habitação de Interesse Social.

Não obstante, somente em 2010, com a edição da Lei 12.305/10, que instituiu a Política Nacional de Resíduos Sólidos (PNRS), o Brasil passou a contar com um instrumento normativo de caráter nacional para tratar da 
referida política pública. Anteriormente, a regulação sobre o tema estava majoritariamente contida nas resoluções do Conselho Nacional de Meio Ambiente (CONAMA) e em mençôes esparsas previstas em outras normas, como na Lei $11.445 / 2007$.

Apesar do prolongado intervalo até a sua edição (o projeto tramitou por 21 anos no Congresso Nacional), diversos dispositivos normativos importantes foram introduzidos, dentre os quais cabe destacar a divisão de competências para atuação dos entes federativos, a instituição de sistemas de logística reversa e a definição de responsabilidade compartilhada pelo ciclo de vida dos produtos.

Tendo em vista a impossibilidade de dissociar a questão social atinente aos catadores de lixo da questão das políticas públicas de gestão dos resíduos sólidos, o legislador não só previu a extinção dos lixões (cujo prazo expirou em 2014), como também procurou oferecer alternativas jurídicas para esses atores sociais. Por exemplo, a facilitação, por meio da dispensa de licitação, na contratação de associaçôes de cooperativas para integrar os sistemas de coleta seletiva.

Como resultado de um tratamento formalmente igualitário dispensado a todos os municípios brasileiros, a Associação Brasileira de Municípios afirma que parte significativa dos referidos entes, em particular, a maioria deles com menos de 50 mil habitantes, não reúne condiçóes técnicas nem financeiras para cumprir a legislação em vigor. Assim, ao ignorar essa realidade, o legislador federal submete o executivo municipal a condições extremamente precárias de autodeterminação, sujeitando-o à incorrer em crime de improbidade administrativa.

\section{v. Lei da Política Nacional de Mobilidade Urbana}

A Lei $12.587 / 2012$ é um instrumento da política de desenvolvimento urbano que tem por objetivo integrar os diferentes modos de transportes e a melhoria da acessibilidade e da mobilidade no território do município. Em seu artigo 2. ${ }^{\circ}$, declara que visa a "contribuir para o acesso universal à cidade, o fomento e a concretização das condições que contribuem para a efetivação dos princípios, objetivos e diretrizes da política de desenvolvimento urbano". Representa, portanto, um complemento das responsabilidades da União quanto ao processo de desenvolvimento urbano, após legislar sobre a política de habitação de interesse social e sobre a política de saneamento ambiental, conforme previsto no Estatuto da Cidade. 
O transporte público coletivo, no entanto, guarda algumas peculiaridades em relação à habitação. Como o saneamento, trata-se de uma função pública de interesse comum de municípios conurbados, como no caso daqueles situados em regióes metropolitanas ou quaisquer outros aglomerados urbanos. Depende, portanto, de cooperação interfederativa para ter efetividade. Esse é outro desafio da política urbana.

Os princípios, diretrizes e objetivos da política de mobilidade são aqueles estabelecidos pelo Estatuto da Cidade, o que torna imperativo que essa política esteja alinhada com o plano diretor municipal, envolvendo a participação social para uma gestão democrática e ambientalmente sustentável da cidade, além da justa distribuição dos benefícios e dos ônus decorrentes do uso dos diferentes modais e serviços.

É curioso e, ao mesmo tempo, alvissareiro que inclua entre suas diretrizes o incentivo ao desenvolvimento científico-tecnológico e ao uso de energias renováveis e menos poluentes. $\mathrm{O}$ incentivo ao uso dessas energias é inédito e só aparece nas normas urbanísticas a partir da Lei 12.836/2013, que altera o Estatuto da Cidade e modifica três de seus artigos com o objetivo de reforçar a preocupação com o meio ambiente nas políticas urbanas. A lei prevê que a Uniáo preste os serviços de transporte público interestadual de caráter urbano, estimulando também ações coordenadas e integradas entre municípios e estados nas áreas conurbadas, aglomeraçóes urbanas e regióes metropolitanas, além de cidades gêmeas (aquelas que se situam em países fronteiriços).

No que tange aos estados, há previsão de que possam delegar aos municípios a organização e a prestação do serviço intermunicipal de caráter urbano, desde que constituído um consórcio público ou um convênio de cooperação com esse fim. Como já mencionado, a constituição de um consórcio público confere maior estabilidade aos acordos intermunicipais, sendo muito pertinentes nessas políticas.

Assim como ocorre com as políticas de habitação de interesse social e saneamento ambiental, também no caso da mobilidade urbana está previsto um plano: o Plano de Mobilidade Urbana, considerado o instrumento de efetivação da política nacional de mobilidade urbana, devendo ser atualizado a cada 10 anos, assim como o Plano Diretor Municipal. Da mesma forma, a obrigatoriedade do plano também abrange os municípios com mais de 20 mil habitantes, e o prazo para se adequar ao plano diretor é de até 3 anos, findo o qual o município fica impossibilitado de receber recursos orçamen- 
tários federais destinados à mobilidade urbana. Esse prazo foi estendido para 7 anos, numa atualização da norma como ocorrera com outros planos, como o já mencionado anteriormente Plano Nacional de Saneamento e Resíduos Sólidos e do Estatuto da Metrópole, a seguir analisada.

\section{vi. Lei do Estatuto da Metrópole}

A edição da Lei 13.089/2015, conhecida como o Estatuto da Metrópole, foi festejada como um importante avanço normativo para induzir melhor governança de territórios que não são reconhecidos como entes federativos, como o caso das regióes metropolitanas e demais aglomerados urbanos. Nesses territórios, a responsabilidade pela gestão de funçôes públicas de interesse comum demanda melhor coordenação interfederativa, como já tinha sido reconhecida desde os anos 1970, quando foram instituídas as primeiras regiōes metropolitanas pelo governo federal.

Com a redemocratização e a entrada em vigor da Constituição de 1988, as regiôes metropolitanas deixaram de ser criadas pela União, passando para a competência dos governos estaduais. Mas, ao mesmo tempo, os municípios deixaram de ser tutelados pelos estados e foram alçados à condição de entes federativos.

Ao estabelecer critérios para a classificação das aglomeraçôes urbanas e estimular a governança interfederativa nesses territórios, o Estatuto da Metrópole reconheceu os limites da atual estrutura político-territorial e forneceu alternativas para conciliar o federalismo de três entes vigentes no Brasil, considerado cláusula pétrea pela Constituição de 1988.

Em tais condiçóes, a governança desses territórios passou a depender de maior cooperação voluntária entre os entes federativos. A maior fragmentação territorial advinda com a criação de, aproximadamente, 1.500 municípios desde a década de 1980 só faria elevar o desafio da governança territorial (Santos, 2008, 2017a).

Mas como estimular a cooperação interfederativa entre entes considerados igualmente autônomos do ponto de vista jurídico, ainda que muitos desiguais em termos econômicos e demográficos?

O legislador desenvolveu critérios obrigatórios para a condução de uma possível "gestão plena" dessas novas unidades territoriais urbanas, quais sejam: a existência de estrutura de governança interfederativa própria; o plano de 
desenvolvimento urbano integrado aprovado mediante lei estadual; e o compartilhamento de responsabilidades entre entes da Federação em termos de organização, planejamento e execução de funçôes públicas de interesse comum.

Importante notar que, apesar dessa estrutura de governança interfederativa prever a participação da sociedade civil em caráter deliberativo nos processos de planejamento e execução de açóes e políticas públicas, a composiçáo desses representantes não foi prevista, dando margem para os legislativos estaduais desenvolverem diversos modelos de instâncias populares colegiadas.

Como forma de induzir os comportamentos estadual e municipal à elaboração e constante revisão de tais documentos técnicos, a União reproduziu uma estratégia reiteradamente adotada nos últimos governos (2003-2016) e passou a condicionar seu apoio para as iniciativas dos estados e dos municípios à existência dos planos no formato e no conteúdo definidos pelo Estatuto da Metrópole. Ou seja, ainda que a União não realize uma intervenção direta no processo de gestão interfederativa, sua presença e capacidade de centralização se manifestam, principalmente, na medida em que a obtenção de recursos federais está condicionada à obediência estrita dos contornos definidos na legislação federal.

O reconhecimento de novas formas territoriais pelo Estatuto da Metrópole apresentou-se como importante avanço normativo na gestão desses espaços. Apesar disso, se a legislação buscou induzir o comportamento cooperativo interfederativo, ficou por avançar em formas também cooperativas no financiamento dos serviços comuns. Ao vetar a Seção II, onde estava prevista a criação do Fundo Nacional de Desenvolvimento Urbano Integrado (FNDUI), as fontes de financiamento desses serviços não receberam um tratamento adequado, restando inalterado o quadro de forte heterogeneidade existente entre os municípios, o que pode comprometer a participação dos municípios maiores e com maior capacidade de arrecadação orçamentária, resistentes a transferir recursos para beneficiar municípios vizinhos.

\section{Urbanização periférica: autoconstrução e cidadania insurgente}

Após experimentar tais avanços institucionais na política urbana, havia expectativas de que os brasileiros estivessem vivendo em cidades mais bem ordenadas e com melhor oferta de infraestrutura urbanística e social. Temos, afinal, vários novos planos nacionais, além de instrumentos jurídicos e urba- 
nísticos para controlar a dinâmica das nossas cidades. Não é esse, contudo, o cenário atual, pois segue em vigor o processo de urbanização periférico que nos tem caracterizado desde o século passado.

A urbanização periférica é caracterizada pela negligência em relação à política urbana que contribuísse para estimular um processo de urbanização inclusivo. Ao longo das cinco décadas (1930-80) em que a industrializaçáo levou o país a crescer a taxas anuais médias de 7\% do PIB, houve intenso processo de urbanização e formação de áreas metropolitanas. Nesse contexto, as migraçóes rural-urbanas pressionaram a demanda por terra urbana sem que o poder público conseguisse, ou mesmo tentasse, controlar a especulação fundiária. Ao contrário, a política habitacional do $\mathrm{BNH}$ contribuiu para a expansão extensiva das cidades ao localizar nas franjas urbanas os empreendimentos imobiliários para a população de baixa renda. Houve, é verdade, importante oferta de crédito para esses empreendimentos, mas a sua localização periférica sem o cumprimento da legislação, que requeria investimento em infraestrutura urbana, produziu moradias isoladas das redes de infraestrutura.

Para além da contribuição do $\mathrm{BNH}$, houve enorme produção imobiliária baseada na autoconstrução nas periferias urbanas, inclusive apoiada por financiamento do mesmo BNH para compra de material de construção (Programa João de Barro). Essa urbanização extensiva autoconstruída foi percebida como solução para o problema da falta de habitação na década de 1980, em que a moradia era vista sobretudo como construção de casas. Ao longo dos anos 1990, a teoria urbana evoluiu para buscar a moradia adequada, aquela situada em área dotada de infraestrutura urbana. Assim, o lugar dos pobres na metrópole passou a depender primeiramente da autoconstrução, ficando a regularização urbanística para depois.

Nas décadas seguintes ao período de intensa industrialização, a indústria foi perdendo participação na estrutura produtiva, mas as maiores cidades seguiram concentrando espacialmente a população e as atividades econômicas, tornando-se economias de serviços. Esse é um movimento que ainda tem prevalecido sobre a desconcentração regional associada à elevaçáo do peso do agronegócio e do extrativismo mineral.

Depois de quase duas décadas em vigor, o Estatuto da Cidade tem sido avaliado como um avanço normativo que frustrou as expectativas por maior ordenamento urbano (Maricato, 2011). Especialmente as grandes cidades passaram a enfrentar novos desafios, como, por exemplo, insegurança pública 
e mobilidade urbana inadequada. Esta última foi agravada pela ampla expansão das cidades, com a produção de moradia popular em locais cada vez mais distantes das periferias dos principais polos de emprego, gerando mais movimento pendulares por parte da população. A maior distância dessas moradias é explicada pela elevação do preço da terra nos locais que contam com mais serviços públicos. Já o isolamento dessa urbanização periférica torna seus residentes ainda mais vulneráveis a questóes de segurança pública.

Mesmo diante de tal evidência, quando o governo federal instituiu um novo programa habitacional dirigido à população com baixos rendimentos, o Programa Minha Casa Minha Vida, repetiu a experiência do BNH de localizar nas áreas periféricas das cidades seus empreendimentos imobiliários (Santos e Vasques, 2019; Compans, 2012). E a explicação para isso segue sendo o preço da terra urbana, maior nas áreas que contam com infraestrutura urbana e que são polos de oportunidades de trabalho.

Ainda assim, tais empreendimentos são defendidos por contribuírem para diminuir o déficit habitacional e promover a regularização fundiária. Mas há estudos que defendem que, no caso do município do Rio de Janeiro, sede dos Jogos Olímpicos de Verão de 2016, os empreendimentos serviram para realojar pessoas que foram removidas das áreas que receberam investimentos contratados por causa do evento esportivo (Santos e Vasques, 2019; Medeiros, 2013).

Apesar das muitas críticas em relação a sua efetividade, os avanços normativos em prol de um urbanismo social suscitaram novos movimentos sociais, chamados por Holston (2013) de cidadania insurgente. De acordo com esse autor, a urbanização periférica, em contexto de aumento dos direitos sociais recepcionados pela Constituição de 1988, permitiu que os pobres pudessem se defender com a linguagem dos direitos. E, assim, se organizassem para pressionar o Estado a estender até a periferia a infraestrutura urbanística. Esta tem sido a estratégia da urbanização periférica: produzir moradias sem obedecer à legislação que tornou obrigatória a implantação de serviços urbanos; depois, constituir uma força política para defender que o poder público implante esses serviços. Ao lograr sucesso nessa luta, os pobres sentem-se responsáveis pela conquista e passam a ter um sentimento de pertencimento mais forte àquele território. E mais, ainda que não consigam regularizar a posse ou propriedade de suas moradias, a linguagem dos direitos tem impedido remoçóes, em linha com o direito social à moradia (Holston, 2013). 
Essa extensão da cidade até a periferia, no entanto, gera um custo adicional para os governos municipais. Esses já estão comprometidos com o cofinanciamento das despesas com políticas de acesso aos direitos sociais (especialmente Educação e Saúde), políticas descentralizadas e de execução desses governos, embora formuladas pela União. Tais gastos competem com o desenvolvimento urbano por alocação orçamentária, o que tem resultado em perda de sua participaçáo percentual no orçamento municipal (Santos, 2017).

A diminuição do orçamento municipal com o desenvolvimento urbano poderia ser mitigada por políticas que envolvessem maior cooperação interfederativa, pelo menos no que tange aos serviços públicos de interesse comum. Esse era o objetivo do Estatuto da Metrópole. No entanto, constatou-se que, após a entrada em vigor desde 2015, o período obrigatório de três anos para que os municípios que fossem parte de aglomerados urbanos elaborassem seus planos diretores urbanos integrados foi revogado pela Lei 13.683/2018 (Santos et al., 2019). Do mesmo modo, ficou adiada, sem prazo definido, a criação de uma autoridade metropolitana, ainda que já tenham sido criadas ou indicados órgãos já existentes para cumprir as funçôes correspondentes em vários estados da federação. Mas a resistência de cidades maiores em participar desses governos metropolitanos segue em curso, como é o caso do município do Rio de Janeiro, que questionou judicialmente a criação do Instituto Rio Metrópole, alegando afronta ao pacto federativo que garante autonomia dos municípios perante os governos estaduais.

À guisa de conclusão, é possível sugerir que a regulação urbanística desse processo de urbanização periférica tem sido impedida pelo aumento sistemático do preço da terra urbana e que as políticas públicas de habitação social têm produzido moradias que afirmam, e não controlam, a urbanização periférica por conta do mais baixo preço da terra nas localidades em que essas políticas são executadas. Assim sendo, pudemos verificar concretamente, em estudo sobre regularização fundiária, expansão urbana e licenciamentos imobiliários no município do Rio de Janeiro, que a atividade estatal voltada para impedir a reprodução das condiçóes de irregularidade fundiária e urbanística tende a tornar-se um processo de "enxugar gelo", por deixar de voltar-se ao estoque de produção imobiliária irregular para agir como um fluxo crescente dessa produção também (Santos e Cruz, 2018). Como agravante, constata-se a ausência de articulação entre as políticas urbanas para levar "a cidade" 
até suas áreas periféricas, o que tem geralmente ocorrido como resultado da chamada cidadania insurgente.

\section{Referencias}

BECKER, B. e EGLER, C. Brasil: uma potência regional na Economia-Mundo. Rio de Janeiro: Bertrand Brasil, 1993.

BOTELHO, A. O urbano em fragmentos: a produção do espaço e da moradia pelas práticas do setor imobiliário. São Paulo: Annablume/FAPESP, 2007.

CASTELLS, M. A sociedade em rede. Sáo Paulo: Paz e Terra, 1999.

CINTRA, A. O. "Planejando as cidades: política ou não política?". In CINTRA, A. O. e HADDAD, P. R. (orgs.). Dilemas do Planejamento Urbano no Brasil. São Paulo: Zahar, 1978.

COPANS, R. "Minha Casa Minha Vida: o revival do BNH?”. In SANTOS, A. et al. (orgs.). Rio de Janeiro: um território em mutação. Rio de Janeiro: Gramma/ FAPERJ, 2012.

COSTA, S. S. Loteamentos irregulares e clandestinos: a cidade e a lei. Rio de Janeiro: Lumen Juris , 2001.

GLAESER, E. Os centros urbanos: a maior invenção da humanidade. Rio de Janeiro: Elsevier, 2011.

HALL, P. "Megaciudades, ciudades mundiales y ciudades globales". In MARTIN, A. (org.). Lo urbano. Barcelona: Ediciones UPC, 2004.

HARVEY, D. O enigma do capital. São Paulo: Boitempo, 2011.

HOLSTON, J. Cidadania insurgente: disjunçóes da democracia e da modernidade no Brasil. São Paulo: Companhia das Letras, 2013.

JACOBS, Jane. Morte e vida nas grandes cidades. São Paulo: Martins Fontes, 2003.

MARICATO, E. O impasse da politica urbana no Brasil. Petrópolis: Vozes, 2011.

MONTE-MÓR, Roberto Luís. "A questão urbana e o planejamento urbano-regional no Brasil contemporâneo". In DINIZ, C. C. e LEMOS, M. B. (eds.). Economia e território. Belo Horizonte: UFMG, 2005, p. 429-46.

SANTOS, Angela M. S. P. Politica urbana no contexto federativo brasileiro: aspectos institucionais e financeiros. Rio de Janeiro: EDUERJ, 2017.

. "Políticas sociais em xeque: impacto da crise sobre as finanças municipais". Boletim Petróleo, Royalties e Regiáo, ano XVI, n. 61, dez. 2018.

e CRUZ, Carlos Eduardo de Souza. "Regularização Fundiária: de seu avanço institucional à reprodução crescente do problema que a originou”. In CORREIA, Arícia Fernandes (org.). Direito da Regularização Fundiária Urbana Sustentável: pesquisa, teoria e prática sobre a Lei Federal n. ${ }^{\circ}$ 13.465/2017. Juiz de Fora: Editar, 2018, p. 35-53. 
e VASQUES, Pedro. “The Brazilian housing program 'Minha Casa Minha Vida' in Rio de Janeiro: an analysis of its social and urban aspects". Artigo apresentado no Seminário CITTA 2019, Cidade do Porto, Portugal, 20 set. 2019. et al. "Governança Territorial: o que avançou com o Estatuto da Metrópole?". Revista Direito da Cidade, v. 12, n. 2, 2019.

SANTOS, M. A urbanização brasileira. São Paulo: HUCITEC, 1996.

SASSEN, S. Los espectros de la globalización. Buenos Aires: Fondo de Cultura Economica, 2003.

STORPER, M. e VENABLES, A. "O burburinho: a força econômica da cidade". In DINIZ, C. e LEMOS, M. (orgs.). Economia e território. Belo Horizonte: UFMG, 2005.

\section{Fontes consultadas:}

IBGE: Contas Regionais, 2017.

IBGE: Censos demográficos, 2000 e 2010.

IBGE: MUNIC, 2001.

Fundação João Pinheiro. Déficit habitacional, 2013.

Ministério do Trabalho, CAGED, 2000 e 2010. 



\title{
Capítulo 7 \\ Governanças Metropolitanas no Brasil: cooperações intergovernamentais e coparticipações instituintes para a sustentabilidade da gestão dos territórios
}

\author{
Augusto César Pinheiro da Silva
}

\section{Introdução}

As discussões sobre as estratégias espaciais de agentes públicos e privados para a gestão de territórios - processo aqui concebido como o somatório de açôes técnicas, institucionais e econômicas sinérgicas entre atores diversos coordenados por uma agenda de políticas públicas conjunturais, temporalmente delimitadas, e que criam condiçóes socioespaciais para transformaçóes estruturais em fragmentos territoriais - tornam as pesquisas no campo das açóes políticas no espaço geográfico cada vez mais expressivas para os diversos campos do saber. Nas chamadas democracias ocidentais modernas, as tendências apresentadas por geógrafos do quilate de João Ferrão e Eduarda Ferreira (Portugal) e André-Louis Sanguin (França) são as de que o estabelecimento das formas e naturezas de interconexão entre as práticas espaciais e as políticas institucionais pluraliza (e potencializa) as açóes público-privadas em múltiplas escalas, tornando a gestão territorial um campo de aprendizado constante para o desenvolvimento de estratégias de ação por agentes diversos em cidades, regióes e países.

$\mathrm{Na}$ contemporaneidade do século XXI, tais ações sinérgicas são complexas pela sua própria natureza, mas ainda entendidas, por vários pesquisadores e 
gestores, como "meros processos" de ordenamento territorial ${ }^{1}$. Na verdade, se coordenadas por agentes públicos competentes, essas ações tendem a ser "mais democráticas" (no sentido da sua capilaridade social) e intergovernamentais em relação à sua funcionalidade.

$\mathrm{Na}$ realidade cosmopolita e metropolitana do século XXI, as formas e os conteúdos para as gestóes territoriais apresentam-se cada vez mais multiescalares, e delas emergem práticas debatidas no mundo acadêmico e nos ambientes político-institucionais para a compreensão de suas naturezas e impactos em espaços geográficos que são tấo mais distintos "no conteúdo" quanto próximos estão "na sua forma".

Nesse campo da abordagem teórico-conceitual da gestão territorial, destacam-se as dimensôes materiais, políticas e simbólicas das metrópoles ${ }^{2}$ (devido à sua condição intrínseca de "nó central" na rede urbana pela força territorial, econômica, técnica, cultural... em variados espaços), das regióes metropolitanas ${ }^{3}$ (condição político-territorial do espaço conurbado pelo "nó"

1 A simplificação do entendimento sobre os ordenamentos territoriais no Brasil e sua dinâmica "puramente técnica" da tradição francesa dos anos de 1960 foi claramente esclarecida por Egler (1992), Souza (1993), Machado (1997) e Moraes (2005), não sendo a perspectiva deste capítulo nem a visão do seu autor. Um ordenamento territorial robusto na sua base de representação político-institucional e técnico-profissional deve estruturar políticas públicas absolutamente importantes para os temas da gestão dos territórios e das governanças. Como afirma Moraes (2005, p. 44), "[...] a revisão (das ideias sobre os ordenamentos territoriais) pode oferecer ensinamentos férteis para novas concepçóes e iniciativas. A retomada do planejamento integrado de base espacial pode originar um útil instrumento para alavancar o crescimento e a justiça social que a nação requer".

2 Como "nós" do sistema urbano de organização territorial concentradores de milhôes de pessoas em cidades/municípios cada vez mais populosos, as metrópoles atuais são células centrais das regiōes metropolitanas (RM), centralizando as atividades de gestão financeira, econômica, técnico-científica e política regional, nacional e mundialmente. Essa força decisória dá a essas formaçóes espaciais centralidade para definir funçóes para outras unidades territoriais multiescalares que, no caso das RM, são os demais municípios a ela conurbados, que sofrem a sua intensidade superlativa no agregado regional metropolitano definido institucionalmente.

3 No Brasil, as primeiras regióes metropolitanas (RM) foram criadas com base na exclusividade de competência do Governo Federal na matéria e foram instituídas por meio da Lei Complementar Federal n. ${ }^{\circ}$ 14/1973. Dessa lei foram definidas as RM de São Paulo, Belo Horizonte, Porto Alegre, Recife, Salvador, Curitiba, Belém e Fortaleza. A RM do Rio de Janeiro foi delimitada e oficializada no ano seguinte, também por Lei Complementar 20/1974. Ou seja, enquanto perduraram os efeitos dessas leis complementares, o Brasil teve nove regióes metropolitanas instituídas por iniciativa do poder federal. $\mathrm{O}$ formato do seu aparato de gestáo, composto por dois conselhos, o Deliberativo e o Consultivo, era semelhante em todas elas e desconsiderava as particularidades da urbanizaçáo de cada um dos territórios em que elas eram instituídas (Davanzo et al., 2010). 
metrópole em larga região dos espectros escalares do espaço geográfico) e do processo de metropolização ${ }^{4}$ (o transbordamento da força decisória das metrópoles, o que faz com que tais centros sejam indutores desse processo para além dos limites da regiáo metropolitana da qual faz parte política e institucionalmente).

Sendo o seu processo indutor (metropolização) mais impactante do que o seu limite territorial (a regiāo metropolitana), as metrópoles (as core area do espectro territorial) readéquam, constantemente, as suas funçóes político-administrativas e funcionais.

Diante do exposto, este capítulo se propóe a caracterizar um modelo de governança metropolitana baseada em dois pressupostos: o primeiro é o dos arranjos institucionais colaborativos entre os entes federativos, o que Souza, desde 2002, chama de cooperação intergovernamental; e o segundo é o da coparticipação instituinte dos atores sociais, em múltiplas escalas, que, por meio do capital social de Putnam (1996), necessitam participar ativamente das decisões da aplicação das políticas públicas nos territórios instituídos. $\mathrm{O}$ campo espacial de observação para essas duas ações, que doravante serão chamadas de açóes verticais (clivagens federativas dos poderes instituídos) e açóes horizontais (redes de solidariedade e cidadania intra e intermunicípios), será a Regiāo Metropolitana do Rio de Janeiro (RMRJ), já que é um exemplo de espaço regional onde as pesquisas sobre estratégias de gestão territorial podem contribuir para o estabelecimento de modelos de governança metropolitana mais adequadas aos padróes atuais de complexidade nas relaçóes socioespaciais.

Para tanto, o artigo está dividido em três partes, além da introdução em curso. A parte II, a seguir, mostrará o contexto metropolitano fluminense na atualidade e os seus maiores problemas em termos da oferta equânime de serviços de interesse comum com funçôes metropolitanas. Na sua parte III, haverá a proposição de uma estrutura de gestão em rede para ambientes metropolitanos cujas açôes políticas integradas entre agentes e atores reforcem

\footnotetext{
4 Não é o objetivo deste capítulo compreender o fenômeno da metropolização como processo institucional, como divulgado pelo IPEA (2013), que se refere, nesse sentido, aos diferentes processos legais que culminaram no atual arranjo metropolitano brasileiro, nem como indutor do poder das formas e conteúdos urbanos para além das suas regiôes de ação institucional. O termo é bastante apropriado não apenas pelo conteúdo que encerra, mas também por lembrar que o processo de metropolização não se resume aos recortes espaciais, ou mesmo, como aponta parte significativa da literatura sobre o tema pós-Constituição brasileira de 1988, ao processo de concentraçáo espacial de atividades produtivas na metrópole, como apontado por Lencioni (2015).
} 
a proposta de Silva (2018), para quem as governanças democráticas em Regióes Metropolitanas desiguais deveriam seguir os pressupostos da Teoria dos Vasos Comunicantes, já que tal sistema busca o equilíbrio entre espaços desiguais a partir das suas forças e pesos também desiguais. Na sua parte IV haverá, finalmente, a apresentação de um esquema de governança cooperativa na perspectiva do desenho institucional sob a ótica do sistema de gerenciamento inter e intracidades de Camagni (2006). Para ele, os princípios básicos de uma organização territorial adequada e sustentável em cidades (e entre cidades e seus municípios) sempre nos ajudarão a responder a questóes fundamentais sobre a natureza, a estrutura e as leis de movimento do sistema urbano contemporâneo e da sua dimensão socioespacial. As referências bibliográficas (parte V) fecharão o capítulo em questão.

\section{O contexto metropolitano fluminense atual: um polo regional para estu- dos singulares de Geografia Política no Brasil}

A grande expansão urbana brasileira desde 1950, notadamente nas capitais da macrorregiáo Sudeste do país, densificou as relaçóes espaciais entre diversas cidades; todavia as suas capacidades de gestão territorial mantiveram-se fragmentadas devido às competências federativas das escalas administrativas em vigor. Mesmo conurbadas em um processo urbano avassalador denominado de "urbanização terciária” (Santos, 1988), "cidades milionárias” em rede oficializadas como "Regióes Metropolitanas" (RM) ${ }^{5}$ que estabeleceram uma nova ordem hierárquica na rede urbana do país, a partir de 1973, mantiveram importantes serviços públicos territorialmente fragmentados, com competências administrativas difusas e concorrentes, o que tornou a qualidade deles altamente questionável.

\footnotetext{
5 Hoje, a Região Metropolitana do Rio de Janeiro (RMRJ) - também conhecida como Grande Rio e instituída após a fusão dos antigos estados do Rio de Janeiro e da Guanabara, unindo as então Regióes Metropolitanas do Grande Rio Fluminense e da Grande Niterói - tem 13.005.430 habitantes (2018) e é a segunda maior área metropolitana do Brasil (após a Grande São Paulo), a terceira da América do Sul e a 20. ${ }^{a}$ maior do mundo. (IBGE, 2019).
} 
Mapa 1 - Percentual da população total municipal atendida com esgotamento sanitário na Região Metropolitana do Rio de Janeiro - 2017 (SNIS)

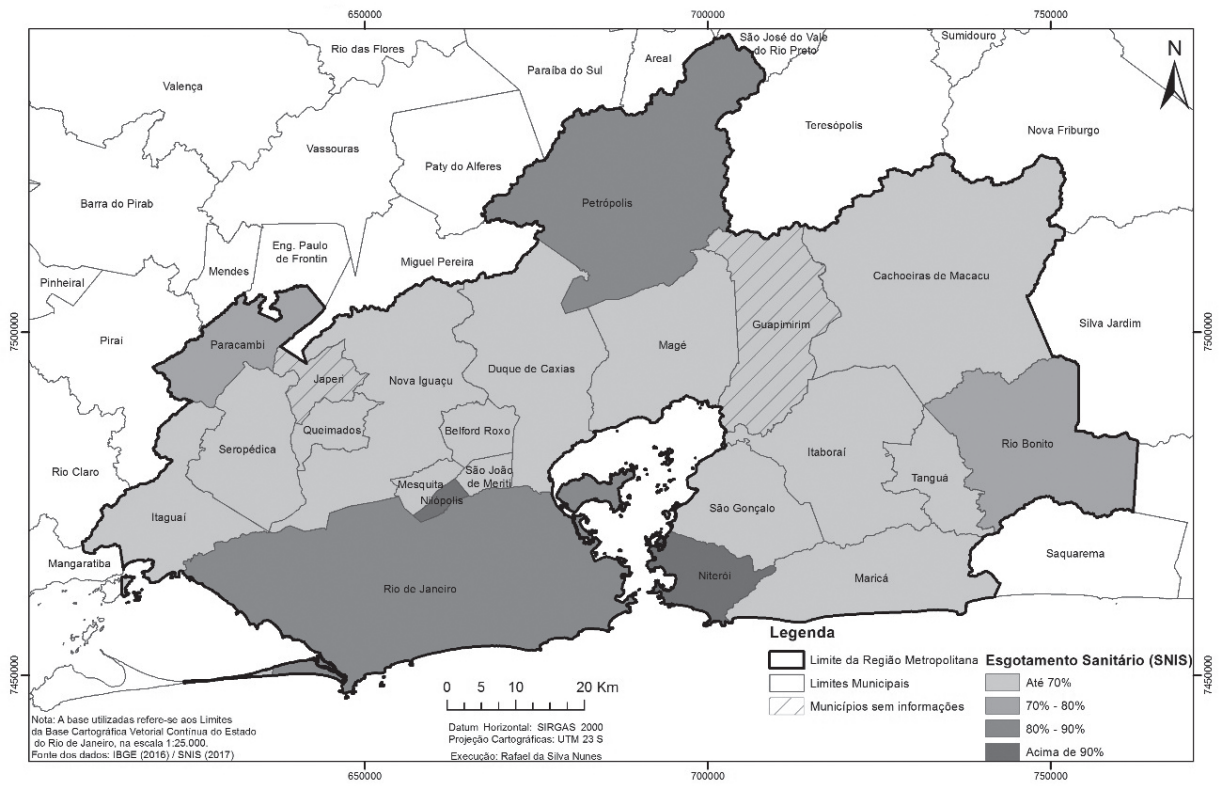

Fonte: Rafael Nunes, GeTERJ (2019).

Levando-se em conta o alto grau de desigualdade socioespacial entre os municípios dessa RM, seus espaços conurbados possuem uma enorme disparidade na distribuição dos sistemas de água potável e de tratamento de esgotos domésticos (mapa 1), de sistemas de coleta, transporte e deposição de resíduos sólidos, segurança pública, e demais serviços. Tal condição afeta o cotidiano de milhóes de pessoas que se aglomeram nos territórios municipais da RMRJ devido à insuficiência desses serviços, que passaram a ser naturalizados como "ineficientes" e mesmo "inexistentes" pelos moradores que estâo à margem de modelos de qualidade de vida geradores de bem estar socioambiental em escala mais ampla. Prefeitos desconectados das dinâmicas regionais nas quais se incluem os seus municípios - o foco da política de representação no Brasil continua a ser a que cabe à parcela territorial do gestor eleito - perdem a oportunidade de tratar os problemas da oferta de serviços essenciais para os habitantes regionais com base nos aspectos espaciais e ecológicos dos territórios geográfica e ecológica dos eventos que, em sua maioria, são muito mais amplos do que o território municipal ${ }^{6}$.

${ }_{6}^{6}$ Para um maior aprofundamento sobre o tema, ler Silva (2018). 
Nesse sentido, os municípios conurbados em uma região metropolitana brasileira continuam a demandar das outras esferas federativas a maior parte dos recursos financeiros que são capazes de resolver (mas não erradicar) os dramas diários gerados pela baixa qualidade dos serviços nos seus territórios. A reduzida cooperação e coparticipação enfraquecem as forças horizontais e verticais que poderiam tornar tais regióes mais autônomas, com projetos de gestáo local capazes de resoluçôes de questôes básicas, como moradia, iluminação pública e saneamento, a partir de práticas geradas pelas expertises de quem vive e atua na regiáo, e afetar as origens estruturantes de tais problemas nos espaços.

Tal incompetência em lidar com problemas locais vem da enorme esquizofrenia territorial do modelo político brasileiro. Este foi reforçado mais ainda pelas deliberaçôes mal alinhavadas da Constituição municipalista de 1988, deixando-se passar, pelos gestores públicos e pela própria população, a percepção espacial a qual Villela Souto (2005, p. 156) se refere no seguinte trecho:

[...] é importante chamar a atenção para o detalhe que uma lei que institui região metropolitana pressupõe um fenômeno econômico, fático, social e urbanístico, que é a conurbação. Portanto, quando existe uma conurbação, os interesses são interpenetrados, não se percebe mais onde termina um município e começa outro, e aí não se pode falar mais em interesse predominantemente local; o interesse passa a ser regional, sendo isso que viabiliza escala entre todos.

No caso da Região metropolitana do Rio de Janeiro, a concentração de cerca de $72 \%$ da população da unidade federada em somente 22 dos seus 92 municípios (IBGE, 2018) faz com que a observação destacada na reflexão do tributarista citado seja ainda mais expressiva, considerando-se a condição demográfica dessa macrorregião no contexto estadual. No mapa 2, é fácil observar a conurbação dos municípios metropolitanos do Rio de Janeiro ${ }^{7}$.

\footnotetext{
Tal distribuição urbana da unidade tem a sua história na constituição do Município Neutro, no Império brasileiro, em 1834. Essa unidade imperial foi transformada em Distrito Federal, em 1891, e permaneceu até 1960, quando, depois de 15 anos como unidade federada também, foi reincorporada ao antigo Estado do Rio de Janeiro, em 1975. A histórica separação territorial iniciada na primeira metade do século XIX e que perdurou 121 anos (Município Neutro - cidade imperial do Rio de Janeiro/Província fluminense - estado do Rio de Janeiro) deixou marcas profundas de ordem sociológica, antropológica e geográfica nos seus habitantes e territórios (Silva, 2018).
} 
Mapa 2 - Densidade Populacional em áreas urbanas na Região Metropolitana do Rio de Janeiro

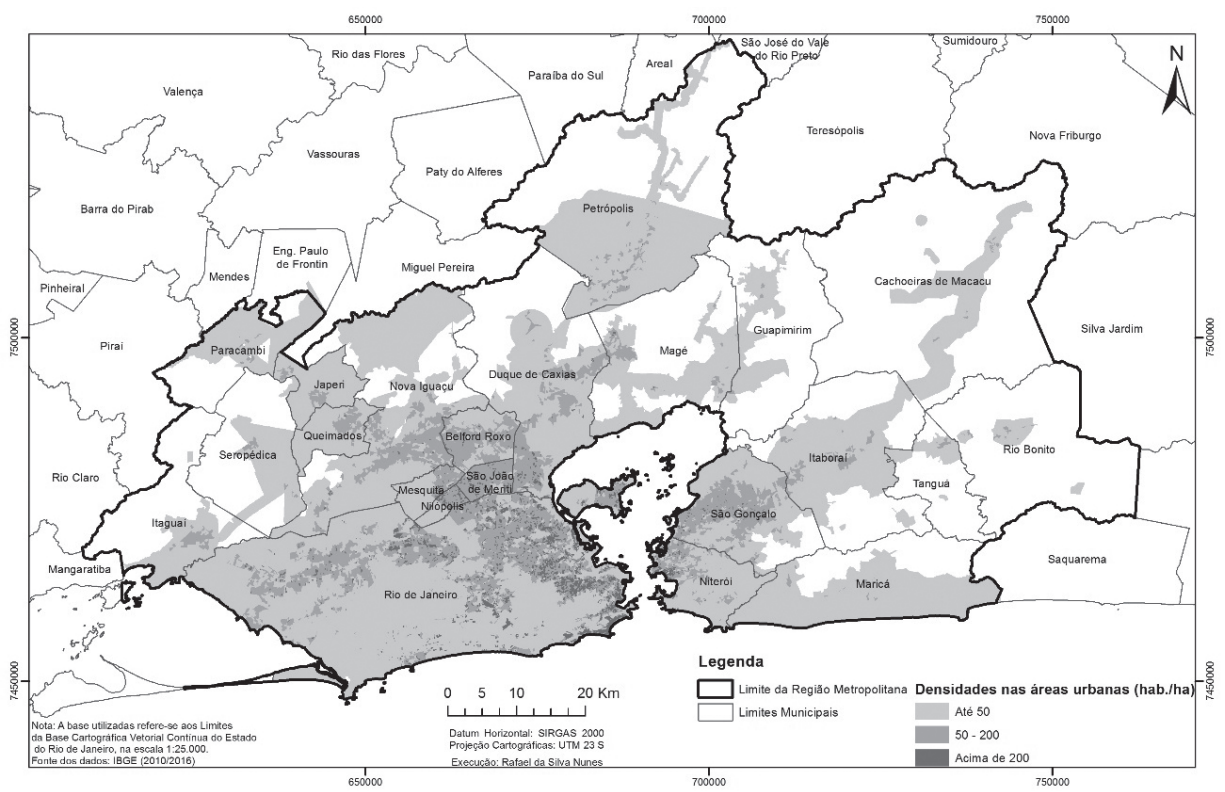

Fonte: Rafael Nunes, GeTERJ (2019).

Apesar das mudanças político-administrativas impostas à cidade do Rio de Janeiro, desde a sua fundação em 1565, e as diferentes arquiteturas de gestáo sofridas pelo seu espaço urbano, em contextos históricos e escalares diferenciados (colonial, imperial, republicano, metropolitano...), o foco da análise aqui proposta deve ser feito com o processo de fusão entre os antigos estados da Guanabara e do Rio de Janeiro, em 1975.

Enquanto o "perfil cosmopolita" atual da cidade do Rio de Janeiro veio se consolidando na população carioca durante os vários momentos político-administrativos vivenciados na cidade-município - ter sido sempre a "sede", desde 1763, criou uma marca da urbanidade e da capitalidade na gestão central do país - o antigo estado do Rio de Janeiro manteve o tradicionalismo de suas atividades rurais ligadas ao modelo agrário-exportador e da história do Brasil como "unidade nacional", e foi pouco modificada até a chegada, via Planos Nacionais de Desenvolvimento (PND I e II), entre 1972 e 1979, dos projetos de modernização logística e energética implementados durante os governos 
militares para o estado, notadamente a partir da fusão político-administrativa e territorial da Guanabara e do Rio de Janeiro, em 1975.

Todavia, deve-se considerar que, desde meados do século XIX, e, com maior intensidade, ao longo do século XX, a periferia imediata do Município Neutro/Distrito Federal foi gradualmente desestruturada do seu perfil rural para outro mais urbano, o que possibilitou a ampliação dos seus núcleos habitacionais mantidos tímidos até o início do século XX (Silva, 2018).

Como reflexo desse processo urbanizador, essa região - que, mais tarde, passaria a ser nomeada de Baixada Fluminense e conhecida, nacional e internacionalmente, pelos seus índices de pobreza crônica e violência explícita - teve a sua população exponencialmente ampliada em um período de menos de um século, recebendo muitos habitantes advindos do território carioca - pobres que se retiravam da cidade do Rio de Janeiro pelo alto valor do solo urbano gerado pelas diversas reformas urbanas da então capital do país e por políticas públicas específicas de urbanização da área com o desmonte, pelo poder central, das atividades primárias dos municípios limítrofes à capital federal - e dos municípios do interior do estado do Rio de Janeiro e de Minas Gerais, além da macrorregião Nordeste do país, populaçóes que eram afetadas por diversos níveis de escassez. Com a ampliação numérica da população dos municípios limítrofes na faixa imediata da fronteira carioca/fluminense, o outrora "cinturão verde da capital do país” conurbou-se ao longo do século $\mathrm{XX}$, ao mesmo tempo que o antigo estado do Rio de Janeiro perdia quantidades absolutas de população, esvaziando-se os municípios, situação que perduraria até os anos de 1990. (Silva, 2016, 2017). O mapa 3, a seguir, reforça a ideia de uma fragilidade em termos do IDH-Municipal entre os 22 municípios que compóem hoje a RMRJ, identificando-se um claro desequilíbrio desse processo de desenvolvimento na faixa imediata da fronteira carioca/municípios fluminenses ao norte da metrópole carioca (Municípios da Baixada Fluminense, como Belford Roxo, Queimados e Japeri), além de grande parte da sub-região do Leste metropolitano, antigas regióes que compunham o Cinturão Verde da atual metrópole carioca. 
Mapa 3 - Índice de Desenvolvimento Humano na Região Metropolitana do Rio de Janeiro - 2010 (PNUD)

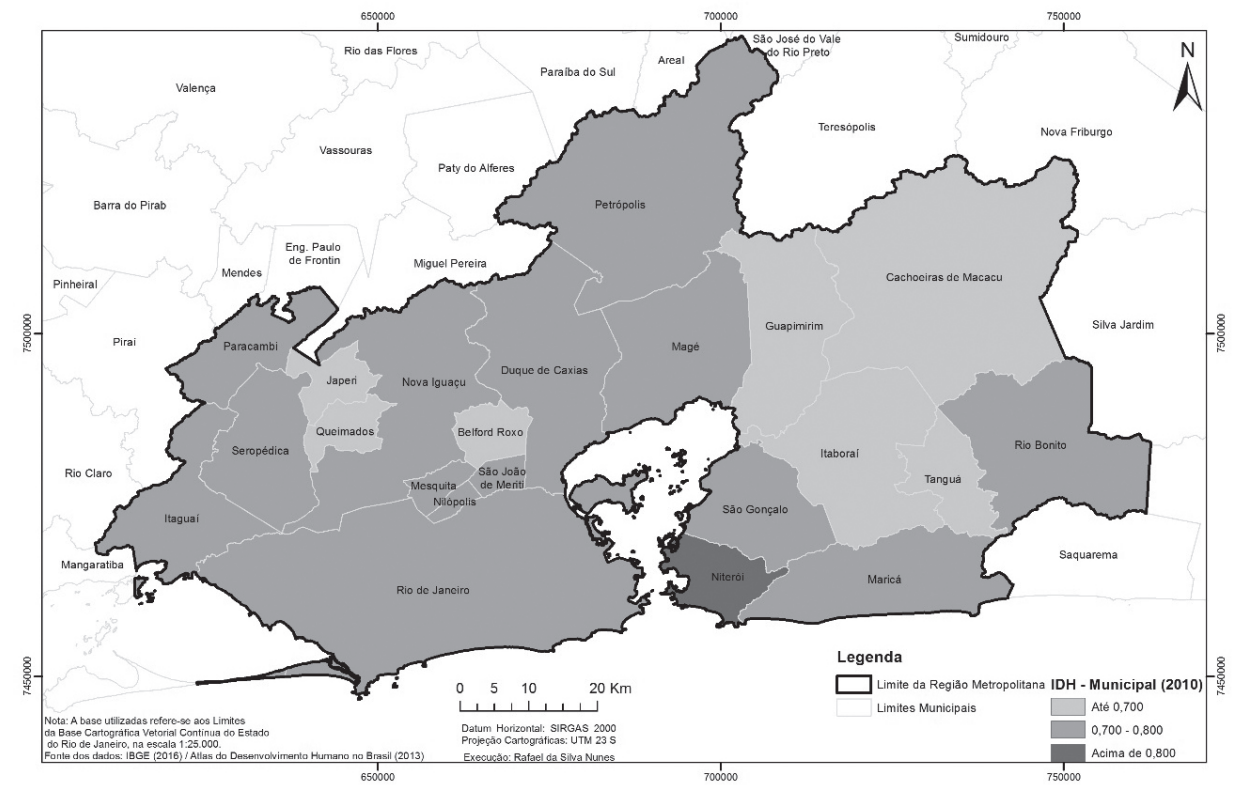

Fonte: Rafael Nunes, GeTERJ (2019).

No atual contexto de crise fiscal e política do país (e, especificamente, a da unidade federada do Rio de Janeiro, depois de quase uma década - de 2006 a 2014 - de uma falsa sensação de pujança econômica com o crescimento "pouco sustentável" de investimentos no território fluminense), é que novas formas de gestão dos territórios voltaram a ser discutidas em um contexto de "mudanças sustentáveis".

A modernização do novo estado do Rio de Janeiro, de 1975, trouxe algumas importantes redes infraestruturais (como as de gás e óleo), rodovias e outros aspectos associados à natureza (projetos de proteção à Mata Atlântica) para o território fluminense; todavia, as maiores transformaçóes foram realizadas no território carioca, desde então, por governos municipais e estaduais, afetando o equilíbrio tanto na RMRJ quanto em toda a unidade subnacional estado do Rio de Janeiro.

Dentre os mais recentes estudos sobre os atuais caminhos para a retomada do crescimento do estado do Rio de Janeiro, destaca-se o discurso institucional e das forças produtivas/entidades de classe de que a "desconcentração" 
(de serviços, investimentos, população...) é um caminho fundamental ${ }^{88}$ para a democratização espacial para as "funçóes metropolitanas". Estas devem servir, com máxima prioridade, a quem vive nos territórios onde a vida cotidiana acontece, e que, quando são coordenadas por agentes exógenos aos espaços regionais metropolitanos, por exemplo, tendem a ser insuficientes e mal gerenciadas. Com base na legislação sobre esse tema, as reflexóes de Grau (1974) são muito pertinentes, pois, para o jurista, no auge dos governos militares brasileiros (1971), as funçôes metropolitanas são:

[...] atividades e serviços urbanos, ou parte destes, que, pela natureza de sua disciplina, implantação ou operação, resultem em conexões e interferências recíprocas entre diferentes municípios, exigindo ação unificada e planejada que ultrapasse seus limites institucionais. Para que o conceito possa ser aplicado, indistintamente, a qualquer realidade metropolitana, basta que se substitua a expressão 'diferentes municípios' por 'diferentes unidades administrativas com atuação na área' [...] (Plano Metropolitano de Desenvolvimento Integrado da Grande São Paulo, 1971, p. 189).

Nas visões de Alves (1998) e Grau (2000), as funçóes metropolitanas são estratégias político-institucionais para que os serviços se tornem públicos e equanimemente espacializados em um dado recorte regional. Para os juristas, as regiốes serão consideradas, de fato, metropolitanas quando certos serviços tenham um tratamento comum e integrado, dando forma pública a eles por meio da rede de municípios conurbados, que os ofertarão de forma horizontal com a participação vertical dos poderes públicos. Tal oferta passaria a ser de "interesse comum entre os poderes municipal e a União (e estadual)", promovendo-se uma "gestão unificada" (Slawinsky, 2006, p. 216) e conjugada

8 O "Mudar a Metrópole" implementado no Rio de Janeiro desde 2015 é um plano de desenvolvimento metropolitano lançado pela Secretaria Estadual de Planejamento e Gestáo (SEPLAG) do Estado do Rio de Janeiro. Também conhecido como o Plano "Modelar a Metrópole", a proposta, subsidiada pelo Banco Mundial, reforça o planejamento metropolitano e sua gestão voltados para a construção de uma metrópole mais ordenada, justa, equânime, próspera e sustentável (SEPLAG, 2017). Observa-se, nos seus documentos oficiais, que o plano resgata um dos principais temas sobre as discussões das competências entre os três níveis de gestão territorial no Brasil (União, Estados e Municípios), em busca da desconcentração dos investimentos da core area metropolitana (no caso, a cidade do Rio de Janeiro) e a melhor articulação regional entre os municípios para que componham as "funçóes metropolitanas" da RMRJ a partir das açóes locais. 
às entidades autônomas no limite da região metropolitana. Tal abordagem se justifica pela necessária confiança político-institucional instituinte, criada com a consolidação de uma sociedade supraterritorializada - entendendo-a como a organização socioespacial cujas açóes conjuntas envolvem atores e agentes que usufruem coletivamente das funçôes metropolitanas da regiáo e para onde a gestáo precisa direcionar as suas açóes principais.

\section{Governanças metropolitanas em espaços desiguais: equilíbrios decisórios em um jogo de "perdas e ganhos" de rendas correntes e ações políticas}

A partir de quadros institucionais de governos em diferentes escalas, seus agentes políticos e atores sociais (cujas intencionalidades, redes e açóes convergem ou divergem em políticas setoriais diversas) é que a governança metropolitana deve ser considerada. $\mathrm{O}$ fator de indução das metrópoles como core areas na definição dos arranjos institucionais voltados para a cooperação poderá ser discursivo, deliberativo ou implementador de políticas públicas, definindo-se o tom e a intensidade das múltiplas gestóes regionais. Nesse contexto, o nível de coesão político-territorial dará o tom das transformações socioespaciais, cuja realização societária estará na realizaçáo de uma justiça social cuja base será a oferta de serviços de melhor qualidade para as populaçóes da região. Nas possibilidades das boas gestóes locais para boas governanças regionais, o conhecimento dos limites dos espaços de escassez, iniquidade e falta de oportunidades se torna a chave para que a esperança comunitária se mantenha na utopia da vida cotidiana.

A definição de boas práticas de governança vem ao encontro das necessidades de serem suprimidas as assimetrias presentes no federalismo brasileiro, assim como na imensa desigualdade socioespacial entre os territórios regionalizados pelo fato metropolitano (em escalas macro e micro), as unidades subnacionais e mesmo os municípios de uma mesma região não metropolitana.

Sob esses aspectos de âmbito territorial, institucional e econômico, Silva (2018) propóe um modelo de governança cooperativa/coparticipativa nas regióes metropolitanas brasileiras, com base na teoria dos vasos comunicantes. Essa referência metodológica tensiona o espaço a conceber, via territórios, arquiteturas complexas de ação política voltadas para "o equilíbrio entre os diferentes” perante as desigualdades socioespaciais dominantes. 
Figura 1 - Sistema de vasos comunicantes. Equilíbrio entre os mesmos conteúdos (serviços, por exemplo) em formas diferentes. Lógica regional para o desenvolvimento de unidades territoriais desiguais

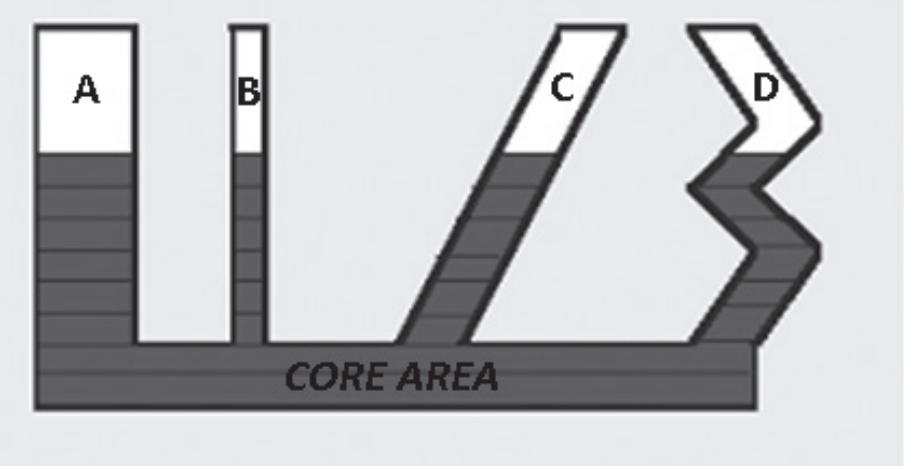

Fonte: Maria Helena Rodrigues GOMES (1985, p. 15). Adaptado.

O mesmo autor refere-se ao sistema de vasos comunicantes como aquele que poderia gerar forte dinâmica associativista entre os vários municípios componentes de uma mesma regiáo metropolitana, a partir da concepção legal que rege os serviços de "funçôes metropolitanas" no Brasil. Considerando-se a figura 1, os vasos A, B, C e D são os municípios desiguais, na sua forma e conteúdo, de uma mesma região metropolitana. Cada um deles exerceria as suas ações de gestão com base nas suas especificidades socioespaciais, culturais e econômicas, buscando-se, com isso, o equilíbrio de acesso de cada um deles aos serviços essenciais à vida metropolitana. Na base do sistema está o município core area da regiáo (a metrópole), que induzirá políticas públicas setoriais na direção das deficiências, dificuldades e potencialidades de cada um dos seus membros, em um processo de autonomização regional via cooperação e colaboração vertical e horizontal.

Portanto, uma governança metropolitana mais equânime se dará a partir das características particulares e singulares (sistema ecológico, estruturas produtivas e de desenvolvimento socioespacial, padróes de infraestruturas, nível de renda, densidade demográfica, padróes de consumo...) das unidades político-territoriais desiguais constituintes do conjunto regional. A posição de destaque desses "nós" metropolitanos será a chave para reequilibrar, regularmente, as forças que definem as prioridades das diversas políticas públicas que buscam o equilíbrio do sistema de "municípios comunicantes entre si". Sendo desiguais e, muitas vezes, complementares, os municípios podem atuar 
como uma "única" força política (de acordo com o sentido da solidariedade horizontal defendida por Santos, em 1993) em prol do reequilíbrio de acesso às funçóes metropolitanas. Os municípios regionalizados, com menores imposiçôes externas (devido ao crescimento da sua autonomia interna e interacional) e abertos ao equilíbrio endógeno, tornar-se-iam os campos, via territórios, para a construção da equidade espacial.

Gráfico 1 - RCL per capita (2009), em R\$, para os 21 municípios da Região Metropolitana do Rio de Janeiro (2014)

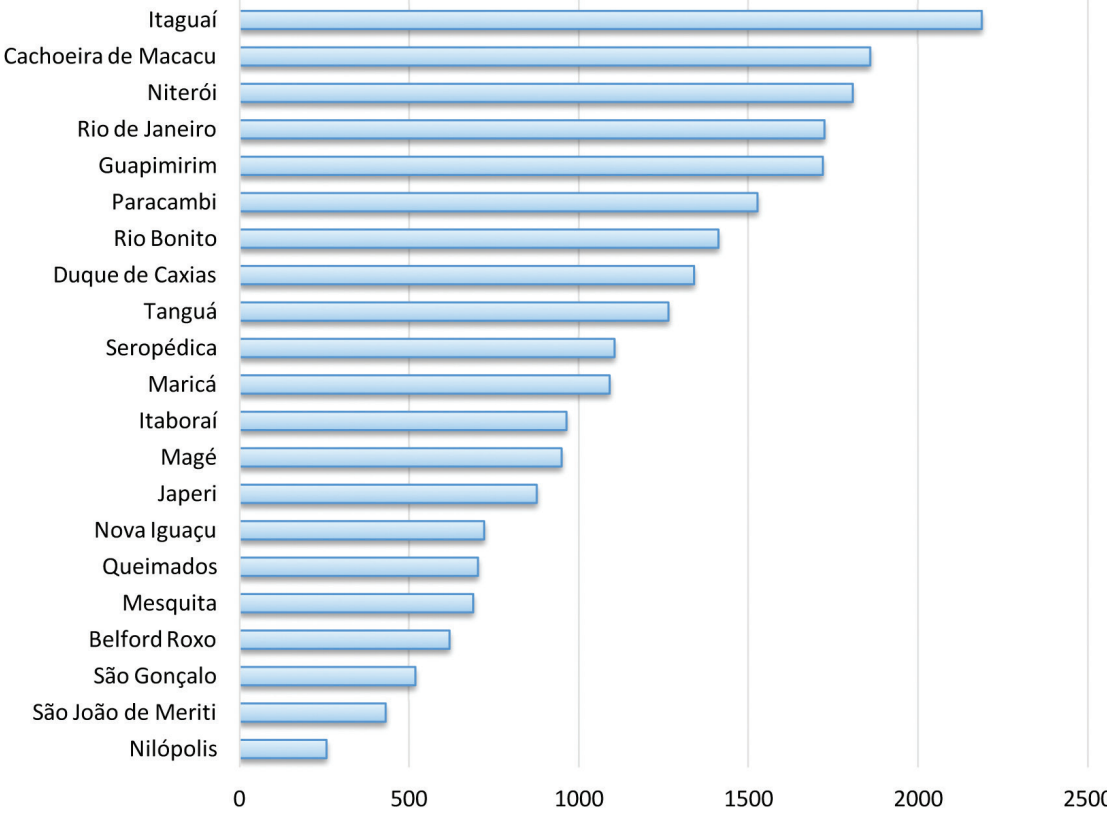

$\square$ RCL per capita em 2009, para os municípios da Região Metropolitana do Rio de Janeiro de 2014

* Dos dados coletados no documento oficial do TCU, de 2009, foram incorporados à RMRJ os municípios de Cachoeiras de Macacu e Rio Bonito, como era em 2014.

Fonte: Secretaria de Planejamento do Rio de Janeiro, 2009.

Um bom exemplo do desafio para o exercício sustentável de governança metropolitana no Brasil é o que pode ser proporcionado pelo uso das diferenças entre as rendas correntes líquidas $(\mathrm{RCL})^{9}$ per capita dos municípios que com-

9 Receita Corrente Líquida (RCL) é o somatório das receitas tributárias de um Governo, referentes a contribuiçóes, patrimoniais, industriais, agropecuárias e de serviços, deduzidos os valores das 
póem essas regiôes brasileiras. Na RMRJ, com base nos dados dos orçamentos municipais de 2009 apresentados no gráfico 1, há expressivas diferenças intermunicipais entre as RCL per capita. Com um orçamento 8,6 vezes maior do que o de Nilópolis (a menor RCL em 2009 da RMRJ), Itaguaí (a maior RCL em 2009 da mesma regiáo) tinha uma população residente quase 1,5 vezes inferior ao do município da Baixada Fluminense, o que ampliava a capacidade do poder local itaguaiense em investir mais recursos em prol dos serviços essenciais no seu território municipal. Nesse contexto, o município carioca do Rio de Janeiro, apesar de possuir $53,4 \%$ de toda a população da RMRJ, ainda manteve uma média corrente de $\mathrm{R} \$ 1.686,63$ per capita, ficando abaixo somente dos municípios metropolitanos de Niterói, Cachoeiras de Macacu e Itaguaí (SECPLAN-RJ, 2009). Seu papel de core area (centralidade) na RMRJ reforça a noção de que é a partir da cidade carioca que grandes sinergias regionais devem ser iniciadas, já que, mais do que arrecadar recursos diversos via captação de investimentos advindos de múltiplas áreas, é o Rio de Janeiro o maior captador de recursos e de força política e interação inter-regional. Já a RMRJ, naquele ano, possuía cerca de $72 \%$ de toda a população do estado, o que tornava a sua ação na unidade subnacional vital para o andamentos dos instrumentos de governança cooperativos e colaborativos aqui defendidos. Sendo assim, se o sentido da governança sustentável é o de fortalecer a base regional das populaçóes conurbadas, então o estabelecimento de lógicas “"comunicantes” no trato regional e intermunicipal dos recursos correntes líquidos é um dos mais importantes exercícios para uma governança voltada para a cooperação entre serviços com funçôes metropolitanas.

O mesmo se repetiu entre outra escala: a das oito Regióes de Governo ${ }^{10}$ do estado do Rio de Janeiro, como se pode observar no gráfico 2. Com uma RCL de R\$ 3.899,24 (a maior do estado no ano de 2009), a Região Norte fluminense, se comparada à RMRJ (a menor renda corrente para o mesmo ano)

transferências constitucionais. Esse dado municipal é fundamental por indicar os recursos que os Governos dispóem a cada exercício para fazerem frente às suas despesas. (FONTE: TCU, 2019)

${ }^{10}$ Houve grandes mudanças na organização regional do estado do Rio de Janeiro, desde 1990. Atualmente, segundo Ribeiro (2017), a Coordenação de Geografia do IBGE (2017) elaborou uma divisão regional do estado identificando cinco Regióes Geográficas Intermediárias (as antigas Mesorregióes) e 14 Regióes Geográficas Imediatas (as antigas Microrregióes). A título de adequar a regionalização do estado aos dados obtidos para este capítulo, a divisão aqui utilizada é a realizada pelo CEPERJ (2014), quando o Rio de Janeiro era uma unidade subnacional dividida, oficialmente, por oito Regióes de Governo, a saber: Metropolitana, Costa Verde, Noroeste, Norte, Serrana, das Baixadas Litorâneas, Centro Sul e Médio Paraíba. 
com seus $\mathrm{R} \$ 1.401,11$, possuía uma população quase 13 vezes menor do que a metropolitana, o que mostra o potencial regional do interior fluminense para o desenvolvimento de arquiteturas mais autônomas de gestão intermunicipal nos municípios mais distantes da core area estadual. A implementação de políticas regionais de desenvolvimento regional pode proporcionar mais equidade na oferta dos serviços essenciais, a partir da emergência de novos agentes econômicos forjados na confiabilidade e comunitarismo regional, desonerando as regióes metropolitanas e outras escalas verticais do poder instituído por açóes políticas ligadas aos cotidianos regionais na escala estadual.

Gráfico 2 - RCL per capita (2009), em R\$, para as oito Regióes de Governo do Estado do Rio de Janeiro

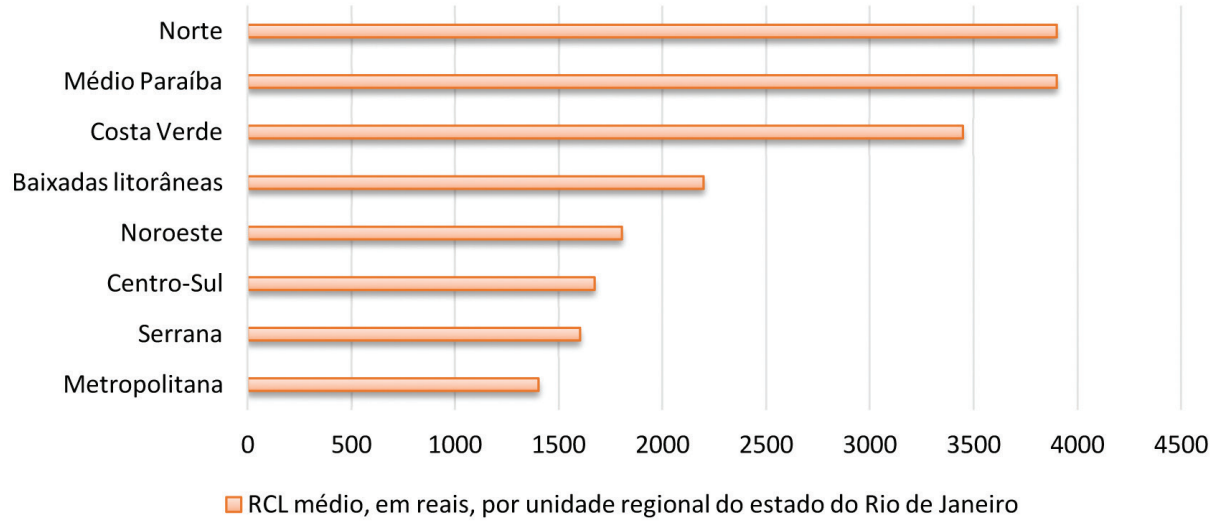

Fonte: Secretaria de Planejamento do Rio de Janeiro, 2009.

Ainda em relação às oito Regiōes de Governo vistas no gráfico 2, a Região Metropolitana fluminense tem os municípios com os menores valores de RCL per capita, apesar de toda a sua importância. No extremo oposto estão a Costa Verde e a Regiáo Norte - cujos municípios se destacam pela notável desigualdade de recursos públicos - com os três "mais ricos" governos municipais de todo o estado (Quissamã, São João da Barra e Macaé). As Baixadas Litorâneas se sobressaem igualmente pela desigualdade intermunicipal, uma vez que possuem três municípios entre os dez "mais ricos" do estado e três entre os 20 de menor RCL per capita (SECPLAN-RJ, 2009).

O gráfico 3 mostra uma situação estrutural bastante preocupante em termos das redes de solidariedade horizontais: a sobrecarga da core area metro- 
politana na participação política instituída nesse espaço regional. Com mais de $40 \%$ dos eleitores regionais em seu território, o município do Rio de Janeiro se torna o "grande problema político" a ser resolvido na escala regional metropolitana. Com os votos para governador da unidade subnacional Rio de Janeiro se concentrando, majoritariamente, no município carioca (e 73\% na RMRJ em relação às demais Regióes de Governo), a dimensão regional do poder instituído é fundamentalmente gerada no território carioca. Portanto, para efeitos de ação regional, as açôes do Legislativo municipal necessitam criar mecanismos de articulaçáo intermunicipal para que as açóes das representaçóes políticas na escala metropolitana possam ser mais equilibradas entre os seus pares.

Gráfico 3 - Porcentagem (\%) de eleitores por município da Região Metropolitana do Rio de Janeiro (2011)

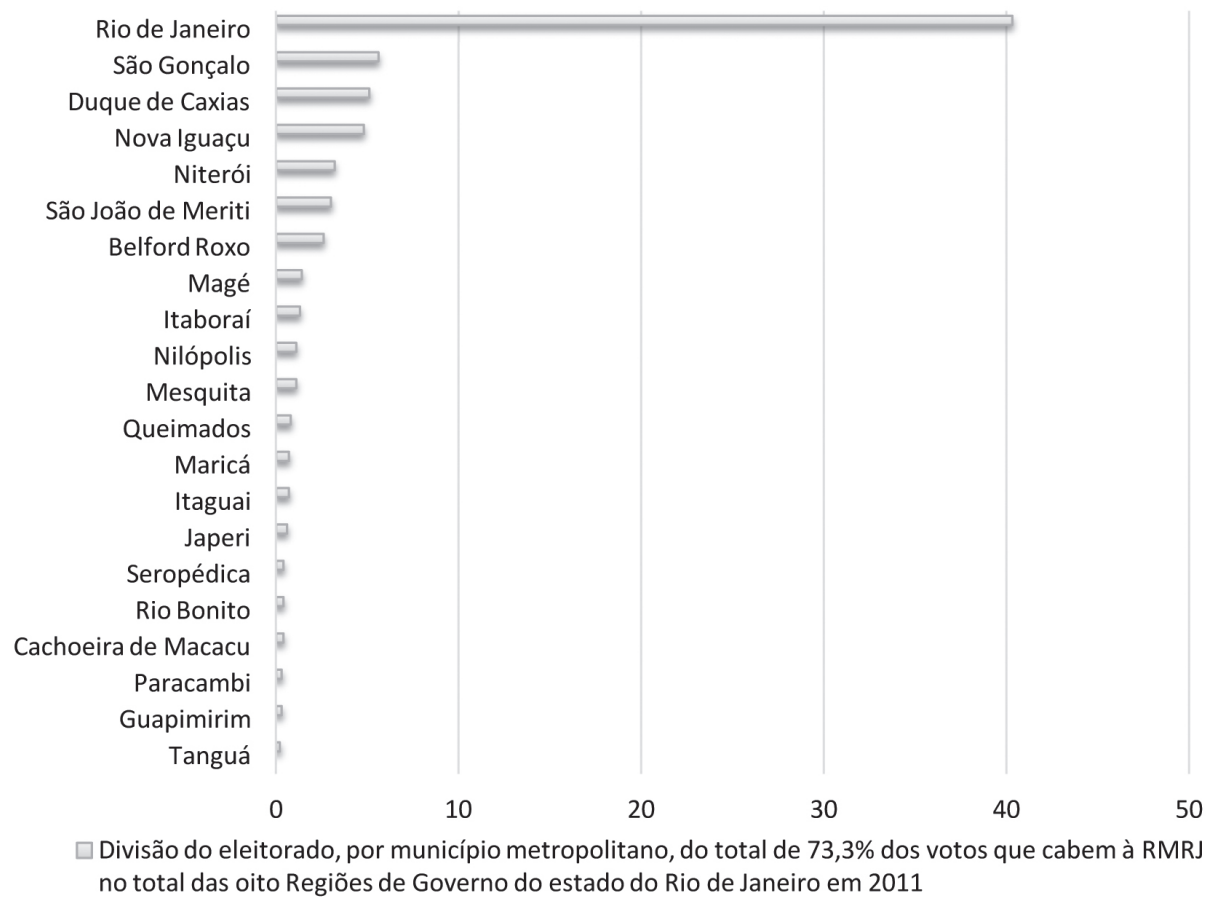

* Dos dados coletados no documento oficial do TCU, de 2009, foram incorporados à RMRJ os municípios de Cachoeiras de Macacu e Rio Bonito, como era em 2014.

Fonte: Secretaria de Planejamento do Rio de Janeiro, 2009.

Os problemas estão postos e caberá aos estudiosos buscarem estratégias diversas para a aplicação concreta de políticas públicas regionais baseadas 
na capacidade de administração de problemas e recursos financeiros líquidos comuns em prol da coletividade conurbada. A governança cooperativa, nesse sentido, seria um conjunto de mecanismos e redes regionais, internos e externos, que permitiriam aos municípios definir e assegurar a execução dos objetivos dos sistemas cooperativados de serviços públicos comuns. Estes, sistemicamente articulados, garantiriam as condiçóes gerais de isonomia dos serviços essenciais, a partir dos conceitos de segurança, eficiência e redução de riscos.

Priorizadas as condiçóes essenciais para a qualidade de vida dos seus habitantes, e não nas prerrogativas políticas e econômicas de sistemas decisórios exógenos, a gestão metropolitana basear-se-ia em uma lógica regional conectada às dinâmicas demográficas e de renda corrente de cada unidade, cujo sistema metropolitano (e demais sistemas regionais) fosse voluntário e livremente comprometido com os cidadãos para uma gestão democrática como princípio basilar.

\section{Exercitando a capacidade de governança metropolitana: uma arquitetura em construção}

Para que sejam definidas arquiteturas regionais de governança cooperativa e coparticipativa baseadas em gestões criadoras de sinergias e interdependências entre unidades políticas instituídas para a resolução de variados problemas espaciais, os estudiosos da Geografia política brasileira precisam focalizar suas investigações em três grandes problemas, inicialmente. O primeiro deles se refere à escala de ação da prática de gestão. Este é o ponto mais discutido neste capítulo, pois o seu foco se refere à escala metropolitana, um dos eventos mais expressivos das tramas demográficas e populacionais da democracia brasileira atual - cerca de 130 dos 210 milhões de brasileiros vivem hoje, 2019, em Regióes Metropolitanas e RIDES, o que torna as RM fontes expressivas de recursos políticos, econômicos e humanos para práticas políticas instituídas e instituintes. Chama-se atenção, contudo, que mesmo a extensão expressiva desses espaços regionais não dão conta da natureza de certos fenômenos geográficos, o que impõe outras assertivas espaciais que envolvem dinâmicas e forças para "além dos territórios instituídos"; o segundo ponto refere-se aos marcos normativos das gestões, tema sobre o qual o país se debruçará nos anos vindouros, pois o atual modelo federativo brasileiro deixa sem solução problemas significativos com relação aos modelos de gestão 
dos territórios, com competências conflitivas e competitivas, e modelos políticos sem redes de conexão sistêmica entre os corpos administrativo e burocrático do Estado, por exemplo; e um terceiro e fundamental ponto, o dos modelos mais dinâmicos, heterodoxos e propositivos de arquiteturas de gestão, que escasseiam nos ambientes institucionais e acadêmicos do país na atualidade.

Esquema 1 - Governanças Metropolitanas

GOVERNANÇAS METROPOLITANAS

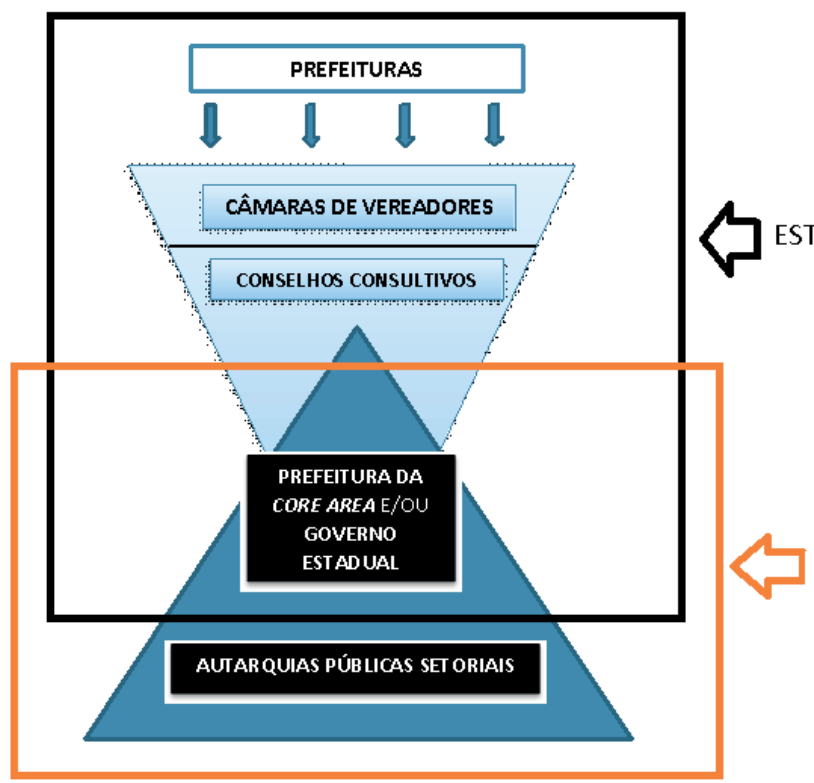

ESTRUTURA DE GESTÃO

Fonte: Camagni, 2006 (adaptado).

Nesse sentido, o esquema 1, adaptado neste capítulo, mesmo que voltado para as relaçóes cidade-cidade, propóe-se a ser um primeiro ensaio de aproximaçáo entre as gestóes e as governanças na escala regional metropolitana. Espera-se que esse exercício possibilite modelos mais alinhados com estratégias de cooperação e coparticipação em espaços conurbados no espectro urbano-metropolitano. O modelo do esquema adaptado estimula mecanismos de açóes políticas capazes de propor autonomias em momentos cruciais das decisões sobre projetos de desenvolvimento em múltiplas escalas. Entendendo as metrópoles pela sua desigualdade no Brasil contemporâneo, as tensôes crescem velozmente em problemas comuns e, às vezes, altamente imbricados no coti- 
diano das manchas metropolitanas. Assim sendo, o esquema em análise pode ser dividido em três partes: A) a estrutura da gestão da core area da RM; B) a estrutura da governança da RM; e, finalmente, C) a governança metropolitana propriamente dita, no seu conjunto de interseçóes escalares.

No seu tópico A, a ação do governo municipal metropolitano proporcionará o nível vertical das relaçóes políticas entre as demais esferas do poder instituído (no caso brasileiro, os governos estadual e federal) na busca por sinergias e contrapartidas que possibilitem, com clareza, a definição das competências institucionais geradas por uma rede institucional de poder. Para tanto, a coleta e mensuração de dados precisa ser mais bem pensada em rede, pois os dados derivados por metodologias díspares dos poderes instituídos no levantamento de informaçóes socioespaciais geram diagnósticos conflituosos sobre as demandas espaciais, afetando a clareza dos problemas comuns a serem resolvidos/melhorados na escala metropolitana ${ }^{11}$. Tão complexo quanto as decisôes setoriais entre os executivos municipal, estadual e federal são os acordos entre as autarquias dessas esferas decisórias, seja pelo perfil das burocracias dominantes - as forças partidárias são importantes nesse contexto -, seja pelo acesso e domínio das técnicas de controle dos dados espaciais.

No seu tópico B, os prefeitos dos municípios componentes da RM em questão devem vislumbrar mecanismos políticos instituintes e instituídos possíveis para que sejam alavancados os desejos e as necessidades das populaçôes regionais. Assessorados por vereadores e movimentos sociais diversos e mobilizadores das questóes mais prementes dos seus municípios, a força de coesão entre os legisladores municipais e a sociedade civil dará o tom da pressão política sobre os executivos, tanto o da core area regional (o município-sede) quanto o do governo estadual e os representantes do Executivo federal (suas autarquias, por exemplo). Nesse jogo entre forças políticas diversas, os vereadores do município central passam a ser os vetores imprescindíveis para a criação de um fórum regional de significância metropolitana, cujo somatório de forças e intencionalidades impulsionaria as açôes estruturantes para problemas comuns. Sem esses vereadores, não há força de coesão política

${ }^{11}$ É comum haver muitos problemas nas bases de dados apresentados por autarquias diversas. Além de distorçóes enormes e discrepâncias que afetam a credibilidade dos dados dos problemas apresentados pelos atores políticos, as agências oficias atrasam muito o levantamento de informaçôes socioespaciais, além, de muitas vezes, utilizarem metodologias distintas e incongruentes para diagnoses necessárias para o enfrentamento dos problemas a serem resolvidos. 
regional capaz de dar suporte às demandas regionais. Nesse sentido, cabe chamar a atenção para a importância dos deputados estaduais eleitos com os votos metropolitanos, que se tornam responsáveis pela pressão política junto ao governo estadual voltada para uma agenda regional metropolitana de fato. $\mathrm{O}$ mesmo se refere aos deputados federais em relação à pressão do Executivo nacional para reforçar a ação política sobre agentes e atores diversos.

No seu tópico C, o da governança metropolitana em si, a sinergia mais importante para o modelo apresentado é a intensa comunicação entre os três níveis do Executivo: os prefeitos dos municípios centrais, governadores de estado (no caso das RIDES, os governadores das unidades da federação envolvidos) e os representantes das autarquias federais. A governança metropolitana assessorada por comitês regionais - como defendido por Alves (1986) - reduz a centralidade da core area e, mesmo que os seus sócios (leia-se: os municípios) não tenham os mesmos objetivos e interesses, eliminam-se problemas comuns no que se refere apenas à relação entre gestores e cidadãos. Estes podem não ter os mesmos objetivos e interesses dos prefeitos, mas a sua força de coesão em rede com os vereadores pode conduzir as políticas públicas de acordo com as decisóes dos conselhos consultivos e, nesse sentido, caberá aos prefeitos cederem às pressóes populares que, por naturezas diversas, tornam-se o problema clássico para a governança regional sustentável: a capacidade das mudanças de planos para a aplicação dos processos de gestão cooperativa.

Não há receitas prontas que indiquem quais são os modelos de gestáo que garantem sucesso para uma governança metropolitana sustentável. Mas o fato é que a gestão das funçóes metropolitanas tende a ter menor ou maior sucesso em razão da capacidade local de se estabelecer a articulação entre, de um lado, os esforços legislativos para atender a demandas já estabelecidas com serviços e investimentos, especialmente aquelas que resultam de passivos urbanos e sociais preexistentes e reconhecidos, e, de outro, a atenção dos prefeitos de municípios com melhores RCL em formular estratégias de competitividade e inovação que permitam, a tais espaços, exercer suas funçóes de polos nas economias regionais e no mundo globalizado.

Trata-se de um modelo de gestáo estratégica fundamentado nos valores e princípios cooperativistas, que estabelece práticas éticas, visando a garantir a consecução dos objetivos sociais e assegurar a governança cooperativa de modo sustentável em consonância com os interesses dos habitantes regionais. Os impactos desse modelo deverão proporcionar: a) ampliação da transparên- 
cia da administração dos governos locais; b) facilitação da colaboração entre as unidades municipais envolvidas; c) contribuição para a sustentabilidade e perenidade do modelo cooperativista e coparticipativo; d) aprimoramento da participação dos moradores e suas representações no processo decisório (não há sustentabilidade sem corresponsabilidade); e) obtenção de melhores resultados diante dos problemas estruturais de origem econômica e financeira; f) incentivaçáo da inovaçáo e da melhoria da qualidade dos serviços metropolitanos; e g) aplicação da responsabilidade social e do comunitarismo como estratégia política instituinte e de coesão social.

No âmbito espacial, as governanças metropolitanas cooperativas e coparticipativas possibilitarão: a) a explicação da noção de aglomeração (ou sinergia) pela concentraçáo de pessoas e equipamentos em lugares determinados, contrapondo-se à noção de dispersão e diferenciação cidade-campo; b) a acessibilidade ou concorrência espacial contribuindo para definir a localização das diversas atividades, residenciais e produtivas, no espaço intra e interurbano; c) a interação espacial (demanda por mobilidade e conexôes) efetivada por fluxos entre pontos fixos situados em distintas localizaçóes em uma ou diferentes cidades, a partir do usufruto de serviços diversificados e especializados; d) a definição de uma hierarquia (ou ordem) das cidades baseada nas leis de organização de espaços urbanos ampliados nas mais distintas escalas (local, regional e estadual); e e) a competitividade inter-regional que responderá pelo dinamismo de um centro metropolitano em relação aos demais centros urbanos/metropolitanos diferenciados.

Com esse exercício de arquitetura para a governança metropolitana, espera-se que novas realidades urbano-regionais, baseadas em esforços coletivos para a melhoria da qualidade de vida no Brasil nas próximas décadas, sejam apresentadas e exercitadas por Estados, agentes e atores dos mais diversos e em múltiplas escalas, para uma reorganização espacial sustentável da atualidade.

\section{Referências}

ALVES, A. C. Saneamento básico: concessões, permissões e convênios públicos. Bauru: EDIPRO, 1998.

CAMAGNI, R. Economía urbana. Barcelona: Antoni Bosch, 2006.

CEPERJ. Mapas regionais. Disponível em: http://www.ceperj.rj.gov.br/. Acesso em: 07 out. 2018. 
DAVANZO, A. M. Q. et al. "O fato metropolitano e os desafios para sua governança”. Revista Paranaense de Desenvolvimento, n. 119, p. 65-83, jul.-dez. 2010.

EGLER, C. A. G. "As escalas da economia: uma introdução à dinâmica territorial da crise". Revista Brasileira de Geografia, v. 53, p. 229-45, 1992.

GOMES, M. H. R. Apostila de Mecânica dos Fluidos. Juiz de Fora: UFJF, 1985.

GRAU, E. R. Regiões Metropolitanas: regime jurídico. São Paulo: José Bushatsky, 1974. . A ordem econômica na Constituição de 1988: interpretação e crítica. 5. ed. rev. atual. São Paulo: Malheiros, 2000.

IBGE - Instituto Brasileiro de Geografia e Estatística. Censo demográfico de 2010. Portal do IBGE. Disponível em: https://ibge.gov.br/. Acesso em: 30 set. 2019.

IPEA - Instituto de Pesquisa Econômica Aplicada. Território metropolitano, politicas municipais: por soluçôes conjuntas de problemas urbanos no âmbito metropolitano, 2013.

LENCIONI, S. "Urbanização difusa e a constituição de megarregiões. O caso de São Paulo-Rio de Janeiro". E-metropolis: Revista eletrônica de Estudos Urbanos e Regionais, ano 6, p. 6-15, 2015.

MACHADO, L. O. "Sociedade urbana, inovação tecnológica e a nova geopolítica". Revista Brasileira de Geografia, v. 55, p. 5-31, 1997.

MORAES, A. C. R. M. Território e História no Brasil. São Paulo: AnnaBlume, 2005.

PLANO METROPOLITANO DE DESENVOLVIMENTO INTEGRADO DA GRANDE SÃO PAULO, Grupo Executivo da Grande São Paulo, GEGRAN, 1971.

PUTNAM, R. Comunidade e democracia: a experiência da Itália moderna. Rio de Janeiro: Fundação Getúlio Vargas, 1996.

RIBEIRO, M. A. C. "Estado do Rio de Janeiro: das Capitanias Hereditárias a uma nova divisão regional”. GeoUERJ, v. 1, p. 249-79, 2017.

SANTOS, M. Metamorfoses do espaço habitado. São Paulo: Hucitec, 1988.

- A urbanização brasileira. São Paulo: Hucitec, 1993.

SECPLAN-RJ - Secretaria de Planejamento do Estado do Rio de Janeiro. Municípios em Dados. Rio de Janeiro, 2009.

SEPLAG - Secretaria de Planejamento e Gestão do Estado do Rio de Janeiro. Disponível em: http://www.rj.gov.br/web/seplag/exibeconteudo?article-id=257671. Acesso em: 21 jul. 2017.

SILVA, A. C. P. "Uma trajetória de investigação de geografia política na Região Metropolitana do Rio de Janeiro”. GEOgraphia, v. 18, p. 95-114, 2016.

. "Governanças cooperativas sustentáveis na gestão metropolitana fluminense: desafios geográficos”. GeoUERJ, v. 1, p. 280-301, 2017.

SILVA, A. C. P. Geografia politica, geopolitica e gestão do território: a integração sul-americana e a inserção das regióes periféricas. 1. ed. Porto Alegre: Editora Letra1, 2018, v. 1.

SLAWINSKI, P. G. R. "Regiões Metropolitanas e serviços públicos de interesse comum”. Revista de Dir. Proc. Geral, n. 60, p. 214-39, 2006. 
SOUZA, M. L. "Reflexão sobre as limitações e potencialidades de uma reforma urbana no Brasil atual". Actas Latinoamericanas de Varsóvia, v. 15, p. 207-28, 1993. . Mudar a cidade: uma introdução crítica ao planejamento e à gestão urbanos. Rio de Janeiro: Bertrand Brasil, 2002.

TCU - Tribunal de Contas da União. Dados econômicossetoriais. Disponível em: https:// portal.tcu.gov.br/controle-e-fiscalizacao/\#tcu-nos-estados. Acesso em: 14 mai. 2019. VILLELA SOUTO, M. J. "Parcerias decorrentes do Programa Estadual de Desestatização”. Revista de Dir. Proc. Geral, v. 59, p. 155-6, 2005. 



\section{Parte III}

Temas-chave no quadro dos novos desafios para os territórios 



\section{Capítulo 8 \\ Agricultura em espaço metropolitano: dinâmicas, tipologias e políticas espaciais para a sustentabilidade}

Patrícia Abrantes

Eduardo Gomes

\section{Introdução}

Numa perspectiva multiescalar, a agricultura tem estado sempre relacionada com a cidade. Da antiguidade à revolução industrial, a cidade de limites bem definidos e extensão reduzida articulava-se com o campo, e este assegurava as trocas de produtos agrícolas com a cidade (Magalhães, 1994).

Com a revolução industrial e a urbanização crescente, dá-se o que muitos autores referem como uma ruptura com esse modelo (Telles, 1994). A agricultura não somente diminuiu em termos gerais, em virtude da modernização das práticas e das técnicas agrícolas, como também a cidade deixou de necessitar dos campos agrícolas envolventes em razão dos novos modelos de organização do sistema agrícola alimentar por via da internacionalização dos mercados, pelo desenvolvimento dos transportes e das vias de comunicação rápidas, assim como pela massificação do retalho (Aubry e Kebir, 2013).

Mas, se olharmos para o interior da cidade, verificamos que a agricultura nunca desapareceu, por exemplo, nos bairros e vilas operárias da cidade industrial, e à medida que a cidade se estendeu, algumas bolsas agrícolas parcialmente urbanizadas permaneceram.

Atualmente, se pensarmos a escala da cidade mais alargada, fragmentada e consumidora de solo natural e agrícola, verificamos a introdução de novas relações e dinâmicas complexas com o espaço rural envolvente. Na cidade alargada, há uma diversidade de funções, atores e usos do solo que se interligam (Lardon, 
2009). A agricultura mistura-se com o uso do solo urbano, a atividade agrícola reinventa-se e frequentemente passa a juntar produção, venda direta e turismo; o novo habitante desses espaços, em alguns casos, também ele passa a ser agricultor. Novos modelos e configurações socioespaciais passam a articular-se nesses espaços (Loudiyi et al., 2017; Pascale, 2009; Zasada, 2011).

Por sua vez, o consumo excessivo de solo agrícola e natural pelo aumento da urbanização dispersa, sobretudo em contextos metropolitanos (EEA, 2006), tem também conduzido a um aproximar da cidade e do campo nos discursos científico e político. As procupaçóes relacionadas com a salvaguarda dos recursos naturais, com as alterações climáticas ou com a alimentação e a segurança alimentar por meio da produção local fazem com que haja, hoje, um maior reconhecimento à escala mundial sobre a importância da Agricultura em contexto Urbano e Periurbano para o desenvolvimento urbano sustentável (Lin et al., 2015; Mok et al., 2014; Opitz et al., 2016).

A Agricultura Urbana e Periurbana (AUP), entendida como o cultivo de alimentos e a criação animal localizada em contexto urbano e periurbano (Mougeot, 2005; Tornaghi, 2014), é multidimensional. Abarca diferentes técnicas de produção (e.g. aquaponia, hidroponia, permacultura) e finalidades (e.g. pedagogia, consumo, venda). Envolve questóes relacionadas com a governança, por exemplo, no acesso ao solo, que pode ser público ou privado, ou na forma de organização que pode ser mais espontânea ou mais instituucional (e.g. hortas comunitárias). Envolve questóes como o acesso aos alimentos, a saúde, o rendimento, o ambiente ou os recursos naturais, como, por exemplo, a gestão da água. Em termos espaciais, envolve diferentes localizaçóes e escalas, pois tanto pode ser praticada nos telhados dos edifícios como em terrenos agrícolas com mais de 50 hectares.

Assim sendo, a AUP, para a construção de uma cidade mais sustentável, deve passar pela sua consideração numa perspectiva ampla e integrada, reconhecendo o seu valor ambiental, econômico, social e de saúde e bem- estar e implicando muito a sua integração no processo de planeamento urbano e ordenamento do território (Loudiyi et al., 2017; Mok et al., 2014; Paül e Mckenzie, 2013; Santo et al., 2016). Ora, dada a sua diversidade, é por muitos autores considerada de difícil medida (Mok et al., 2014). Aliás, como medir a agricultura praticada nos terraços e telhados dos edifícios? Ou como quantificar a agricultura praticada num terreno classificado para 
urbanização, mas ocupado por práticas agrícolas espontâneas? Ou como articular a agricultura com as dinâmicas urbanas em curso?

Em Portugal, escasseiam estudos sobre a Agricultura Urbana e Periurbana (AUP) e sobre a sua relação com as dinâmicas urbanas e periurbanas. Por um lado, a agricultura é tida numa perspectiva setorial e muito ligada ao desenvolvimento rural. Por outro lado, os estudos são muito centrados na agricultura urbana, por exemplo, nos projetos associativos e municipais em curso e na sua integração no planeamento municipal, tendo como exemplo paradigmático o caso do munícipio de Lisboa (Cancela, 2014; Delgado, 2018).

Este capítulo de livro aborda a relação entre urbanização, metropolização e agricultura, com particular destaque para Portugal e para a região metropolitana de Lisboa (RML). A partir duma leitura desses conceitos, propóe-se uma tipologia para medir as configuraçôes e dinâmicas socioespaciais agricultura-urbanização no contexto metropolitano. No final, discute-se como as políticas espaciais, nomeadamente de urbanismo e ordenamento do território, podem enquadrar os diferentes tipos encontrados na RML.

\section{Urbanização e agricultura}

A revolução industrial marcou profundas alterações no processo de urbanização, sendo este um dos fenômenos espaciais mais marcantes do século XX. Marcou também a passagem de uma população predominantemente rural, para uma população vivendo maioritariamente em cidades. Em 2015, na Europa, estimava-se que $75 \%$ da população vivia em áreas urbanas (EUROSTAT, 2016).

Sobretudo nos países ditos mais industrializados, o processo de urbanização alterou inevitavelmente os padrôes de povoamento e, por conseguinte, as relaçóes campo-cidade, tornando-as mais complexas e com novas expressóes espaciais. É sobre o ciclo evolutivo das cidades e como este tem vindo a marcar as relaçóes cidade-campo que nos dirigimos seguidamente (esquema 1).

Embora com intensidades e ritmos diferentes, várias fases marcaram o processo de urbanização. Van der Berg associa as fases demográficas das cidades às alteraçóes no sistema econômico e no modelo de transportes, nomeadamente: Urbanização, Suburbanização, Desurbanização e Reurbanização (Marques da Costa, 2007, p. 73). 
Esquema 1 - Principais processos de urbanização ao longo do século XX

\begin{tabular}{|c|c|c|c|c|}
\hline & $\begin{array}{c}\text { Antig. -> Rev. } \\
\text { Ind. (XIX) }\end{array}$ & $\begin{array}{c}\text { XIX->Anos } \\
1950 / 60\end{array}$ & $\begin{array}{c}\text { Anos } 1970- \\
>80\end{array}$ & $\begin{array}{c}\text { Anos 1980/Séc. } \\
\text { XXI }\end{array}$ \\
\hline $\begin{array}{l}\text { Fases do } \\
\text { desenvolvimento } \\
\text { urbano }\end{array}$ & & $\begin{array}{l}\text { Urbanização/ } \\
\text { suburbanização }\end{array}$ & $\begin{array}{l}\text { Desurbanização } \\
\text { • Contra-urbanização }\end{array}$ & $\begin{array}{l}\text { Reurbanização } \\
\text { • Metropolização (grandes cidades) }\end{array}$ \\
\hline $\begin{array}{l}\text { Dinâmica cidade- } \\
\text { agricultura }\end{array}$ & $\begin{array}{l}\text { Agricultura na } \\
\text { próxima da } \\
\text { cidade }\end{array}$ & $\begin{array}{l}\text { Agricultura } \\
\text { afasta-se da } \\
\text { cidade }\end{array}$ & $\begin{array}{l}\text { - Rurbanização } \\
\text { A cidade } \\
\text { aproxima-se do } \\
\text { campo (na } \\
\text { dimensão } \\
\text { sociocultural) }\end{array}$ & $\begin{array}{l}\text { - Periurbanização } \\
\text { (processo generalizado de extensão da } \\
\text { população em espaço rural na influencia } \\
\text { de uma cidade) } \\
\text { A cidade aproxima-se da } \\
\text { agricultura }\end{array}$ \\
\hline $\begin{array}{l}\text { Padrões } \\
\text { de uso } \\
\text { do solo }\end{array}$ & $\begin{array}{l}\text { Modelo Von- } \\
\text { Thunen } \\
\text { (escala de } \\
\text { proximidade) }\end{array}$ & $\begin{array}{c}\text { Separação de } \\
\text { usos } \\
\text { vs. } \\
\text { Agricultura no } \\
\text { interior da } \\
\text { cidade }\end{array}$ & $\begin{array}{l}\begin{array}{l}\text { Agricultura } \\
\text { afasta-se da } \\
\text { cidade }\end{array} \\
\text { Consumo de } \\
\text { solo agrícola }\end{array}$ & $\begin{array}{l}\text { Acentua-se o consumo de solo e } \\
\text { Mix de usos (larga escala) }\end{array}$ \\
\hline & & $\begin{array}{l}\text { Consumo de } \\
\text { solo agrícola }\end{array}$ & & \\
\hline
\end{tabular}

Fonte: Adaptado de Marques da Costa (2007).

Assim, podemos identificar uma primeira fase de "urbanização" associada ao processo de industrialização que desencadeou um desenvolvimento urbano sem precedentes. A cidade cresceu muito à custa de um forte êxodo rural da população, e o campo afastou-se da cidade. Com o desenvolvimento dos sistemas de transporte urbano (coletivo), sobretudo até meados dos anos 1950, a urbanização caracterizou-se por um processo que muitos autores designaram por suburbanização, ou seja, de expansão da população pela periferia imediata da cidade, em razão do desenvolvimento das atividades econômicas no centro urbano e dos custos associados à habitação.

Essa fase caracteriza-se, do ponto de vista espacial, por um modelo de expansão urbano compacto e radial a partir do centro da cidade, sobretudo por conta dos eixos de transporte coletivo (rodoviário e ferroviário). $\mathrm{O}$ transporte também permitiu afastar o campo da cidade. A produção agrícola deixou de necessitar de estar próxima da cidade, registrando-se aqui uma ruptura com o modelo de von Thunen. Por exemplo, o cultivo de produtos hortícolas afasta-se da cidade porque os custos de transporte são mais baixos e há escoamento mais facilitado (Moindrot, 1992). Há, assim, uma separação clara das funções agrícola e urbana, embora subsista alguma agricultura, de muito pequena escala na cidade, muito associada a questóes culturais ou de segurança alimentar (Loudiyi et al., 2017; Tornaghi, 2014).

A partir de 1970, com o advento da globalização, concretamente, com a revolução dos transportes e das telecomunicações, o fenômeno de urbaniza- 
ção intensifica-se, marcando uma ruptura profunda na organização espacial. Emergem novos processos e formas de urbanização. De fato, a generalização do transporte individual (automóvel) e o crescente aumento da mobilidade contribuíram para o afastamento das populaçôes dos centros das cidades, seguindo-se mais tarde as atividades econômicas.

Dois conceitos tendem a definir os processos em curso desde essa década até meados dos anos 1980, marcando o que se poderá caracterizar, grosso modo, como a "saída" da população para as áreas rurais ou "contraurbanização" (counter-urbanization) e rurbanização (rurbanization).

Os dois conceitos, teorizados por Brian Berry (1974) e Bauer et Roux (1976), respectivamente, o primeiro numa perspetiva anglo-saxônica, o segundo numa perspetiva francófona, referem-se ao declínio da população das cidades e à procura de espaços rurais por parte da população urbana, marcando, para alguns autores, o fim das cidades e da tradicional oposição cidade/campo pelo emergir do urbano generalizado. Esse processo deveu-se à perda de atratividade das áreas mais centrais (mais poluídas, congestionadas e caras) e à desconcentração do sistema produtivo em virtude do crescente aumento da mobilidade (transportes).

O processo de disseminação da população urbana sobre o espaço rural foi amplamente estudado, principalmente ao longo dos anos 1980, concretamente, na sua dimensão socioeconômica, concluindo-se que define sobretudo um processo social de difusão de modos de vida urbanos em espaço rural, tanto na proximidade como em áreas mais afastadas da cidade (Merlin, 2009). Fenômenos de segunda residência, de população emigrante que retorna à sua aldeia de origem, de citadinos que recuperam imóveis para turismo rural são exemplos de situaçóes que trazem novos modos de vida urbana ao espaço rural sem, no entanto, alterar grandemente a estrutura espacial das áreas rurais. $\mathrm{Ou}$ seja, a cidade aproxima-se do campo, numa dimensão sociocultural, mas a agricultura mantém-se separada, e o consumo de solo começa a evidenciar-se.

Nos anos 1980, as aglomeraçóes urbanas começaram a atrair novamente população, entrando numa fase que se designou de reurbanizaçáo. Mas esse processo prende-se com o alargamento das áreas de influência funcional das cidades. Dois conceitos estão associados:

1) Metropolização. $O$ processo de metropolização, emergente sobretudo a partir da década de 1980 com a globalização da economia, caracteriza, segundo Merlin e Choay (1996), o retorno das populaçóes às cidades de hierarquia superior 
(metrópoles) e, sobretudo o desenvolvimento de atividades de terciário superior nessas cidades (i.e. sedes sociais de empresas, atividades financeiras e serviços conexos, entre outros). Em certa medida, poderá opor-se ao processo de contraurbanização/ rurbanização referido anteriormente. Contudo, o que se define como retorno das populaçôes e atividades às grandes cidades, não é mais que o entendimento de que a cidade se alargou espacialmente, visto que atividades e população vivem mais afastadas do centro das cidades, embora na (inter)dependência destas. De fato, a disponibilidade fundiária na periferia, associada ao custo do imobiliário nas imediaçóes da cidade, e a maior facilidade das deslocaçóes pendulares em automóvel devido à melhoria considerável das vias de comunicação rápidas dão origem à noção de cidade alargada, regiāo metropolitana, região urbana funcional, metápole, entre outras terminologias (Abrantes, 2011).

São as grandes cidades que recebem a maior parte das infraestruturas de transporte e telecomunicaçóes; é aí que se desenvolvem e diversificam as atividades econômicas; e é aí que as populações procuram emprego, num processo que acaba por ser cumulativo e quase irreversível (i.e. metropolização). Assim, é nas grandes cidades (metrópoles) que os processos tendem a ser mais complexos e intensos (Abrantes, 2011). O conceito de metropolização refere-se a um conjunto de processos, sobretudo econômicos e espaciais, e a uma perspectiva multiescala (da escala global à escala local), sendo muito específico de certas cidades, as metrópoles. Abarca, no entanto, um processo espacial designado de periurbanizaçâo, sendo que esse conceito é mais adaptado aos processos que têm vindo a ocorrer na maior parte das cidades de escaláo inferior.

2) Periurbanização. Este processo foi, sobretudo, teorizado no início da década de 1990 por (Dézert et al., 1991), traduzindo a expansão da população urbana sobre o espaço rural, mas, ao contrário do conceito de rurbanização/contraurbanização, pressupondo a existência de uma relação intrínseca com a cidade (ex. deslocaçôes casa-trabalho), causando importantes transformações espaciais.

O conceito de periurbanização traduz o processo pelo qual a população se expande sobre o espaço rural na influência de uma "cidade-centro". "La périurbanisation est une expansion, une croissance de la ville vers ses campagnes environnantes, mais qui à la difference de la banlieue traditionnelle aglomerée à la commune-centre, se fait de manière relativement diffuse dans un espace qui garde partiellement son caractère rural" (Hervouët, 2001, p. 124). O conceito de periurbanização foi, sobretudo, teorizado pela escola 
francófona, numa perspectiva de entender o processo nas suas várias dimensões, socioeconômica, funcional e espacial.

A tradução espacial ou a expressão física do processo de metropolização e de periurbanização é a urbanização dispersa (ou urban sprawl). Esse conceito torna-se banalizado desde finais da década de 1990, embora tivesse surgido, bem antes mesmo do conceito de periurbanizaçáo, por via da escola norte-americana (Berry, 1974). Este refere-se ao "physical pattern of low-density expansion of large urban areas, under market conditions, mainly into the surrounding agricultural areas" (EEA, 2006, p. 6). Ou seja, trata-se de uma forma espacial difusa, extensiva e alargada, na maioria dos casos, descontínua e fragmentada em relação à cidade, sendo marcada pela coexistência e, portanto, pela mistura de diferentes usos e ocupaçóes do solo (urbano, agrícola e florestal). Em algumas cidades (sobretudo nas metrópoles) é pontuada por centralidades secundárias.

Se, por um lado, os processos de metropolização e periurbanização contribuem para o excessivo consumo de espaço agrícola, alguns autores afirmam, por outro lado, que permitem aproximar novamente os espaços urbano e rural, mas a uma escala mais alargada.

Esse novo estágio de urbanização contribui para uma maior complexidade espacial e relacional. Os espaços agrícolas diversificam-se, misturam-se com o urbano, têm novas práticas muito associadas à multifuncionalidade da atividade e há uma multitude de atores intervenientes e escalas de ação (Lardon, 2009; Loudiyi et al., 2017). É sobre a agricultura em contexto urbano e periurbano em Portugal que nos dedicamos seguidamente.

\section{O panorama da agricultura urbana e periurbana em Portugal Continental}

A agricultura, em Portugal, sofreu um forte decréscimo, à semelhança da generalidade dos restantes países. Tal situação deveu-se à rápida terciarização da economia e à urbanizaçáo. Em cinquenta anos, Portugal passou de uma matriz rural, para uma matriz urbana. Nos anos 1960, com a rápida industrialização da economia, dá-se um forte êxodo rural, sobretudo para Lisboa e para o Porto, fazendo crescer os seus subúrbios. O sistema urbano bipolariza-se nessas duas cidades. Posteriormente, a expansão urbana alarga-se ao litoral, havendo, sobretudo na década de 1990, uma consolidação de algumas cidades médias, essencialmente as capitais de distrito. $\mathrm{O}$ interior praticamente esvazia-se e torna-se envelhecido (Abrantes, 2011; Marques da Costa, 2002; Marques da Costa, 2017; Sá Marques, 2004). 
De fato, a população urbana, em Portugal, aumentou consideravelmente nos últimos cinquenta anos. De acordo com Peixoto (1987), esta era de cerca de 22\% em 1960; em 2011, esse valor aumentou para 72\% (INE, 2011b). Já de acordo com os dados censitários sobre a agricultura, passamos de cerca de $50 \%$ da população ativa a trabalhar no setor agrícola nos anos 1950 para cerca de $5 \%$ em 2009.

Os dados dos censos agrícolas mostram, relativamente à superfície agrícola utilizada (SAU), que, em 2009, existiam 3,6 milhões de hectares de SAU, tendo-se perdido cerca de 400 mil hectares de 1989 para 2009 (INE, 2011a). Houve grandes perdas no litoral. Por exemplo, a Área Metropolitana do Porto perdeu 15 mil hectares de SAU em 20 anos; o Oeste perdeu cerca de 35 mil hectares; e a Área Metropolitana de Lisboa perdeu 10 mil hectares. A mão de obra agrícola e o número de exploraçôes agrícolas seguiram a mesma tendência.

Não obstante, é no Litoral, nomeadamente no Oeste, na Lezíria do Tejo e no Litoral Norte, que encontramos grande parte da agricultura altamente competitiva e de exportação do país, sobretudo de produtos hortícolas e frutas. Assim, apesar do decréscimo, a agricultura no litoral urbanizado de Portugal detém ainda alguma relevância.

De fato, considerando a tipologia de áreas urbanas para fins estatísticos, proposta em 1998 pelo INE/DGOTDU ${ }^{1}$, que classifica o território nacional em três categorias com base no grau de urbanização, verifica-se que existe uma percentagem relevante de SAU, mão de obra e exploraçóes agrícolas em áreas predominantemente urbanas (APU), cerca de 14\% em todos os casos (tabela 1 e mapa 1). Essas APUs localizam-se essencialmente no litoral, sobretudo nas Áreas Metropolitanas de Lisboa e do Porto. Note-se que mesmo as áreas medianamente urbanas (AMU) apresentam valores consideráveis de SAU, mão de obra e exploraçóes agrícolas e localizam-se também elas, no essencial, no litoral, entre o Minho e Sines e na regiáo do Algarve.

1 De acordo com o INE/DGOTDU (1998), são “Áreas Predominantemente Urbanas” as:

- freguesias urbanas, ou seja, freguesias que possuam uma densidade populacional superior a 500 $\mathrm{hab} / \mathrm{km}^{2}$ ou que integrem um lugar com população residente igual ou superior a 5.000 habitantes;

- freguesias semiurbanas contíguas às freguesias urbanas, segundo orientaçóes e critérios de funcionalidade/planeamento, sendo consideradas freguesias semiurbanas todas as freguesias não urbanas que possuam densidade populacional superior a 100 e inferior ou a $500 \mathrm{hab} / \mathrm{km}^{2}$ ou que integrem um lugar com população residente igual ou superior a 2.000 habitantes e inferior a 5.000 habitantes;

- freguesias sedes de concelho com mais de 5.000 habitantes. 
Tabela 1 - Percentagem de SAU, agricultores e exploraçôes por tipologia de áreas urbanas

\begin{tabular}{cccc}
\hline & SAU (\%) & N. $^{\circ}$ de agricultores (\%) & N. ${ }^{\circ}$ de exploraçôes (\%) \\
\hline APU & 13.80 & 14.02 & 14.27 \\
\hline AMU & 20.50 & 26.36 & 26.36 \\
\hline APR & 65.60 & 59.62 & 59.37 \\
\hline
\end{tabular}

Fonte: INE, 2011.

Mapa 1 - Tipologia de áreas urbanas em 2009, por freguesia, em Portugal Continental

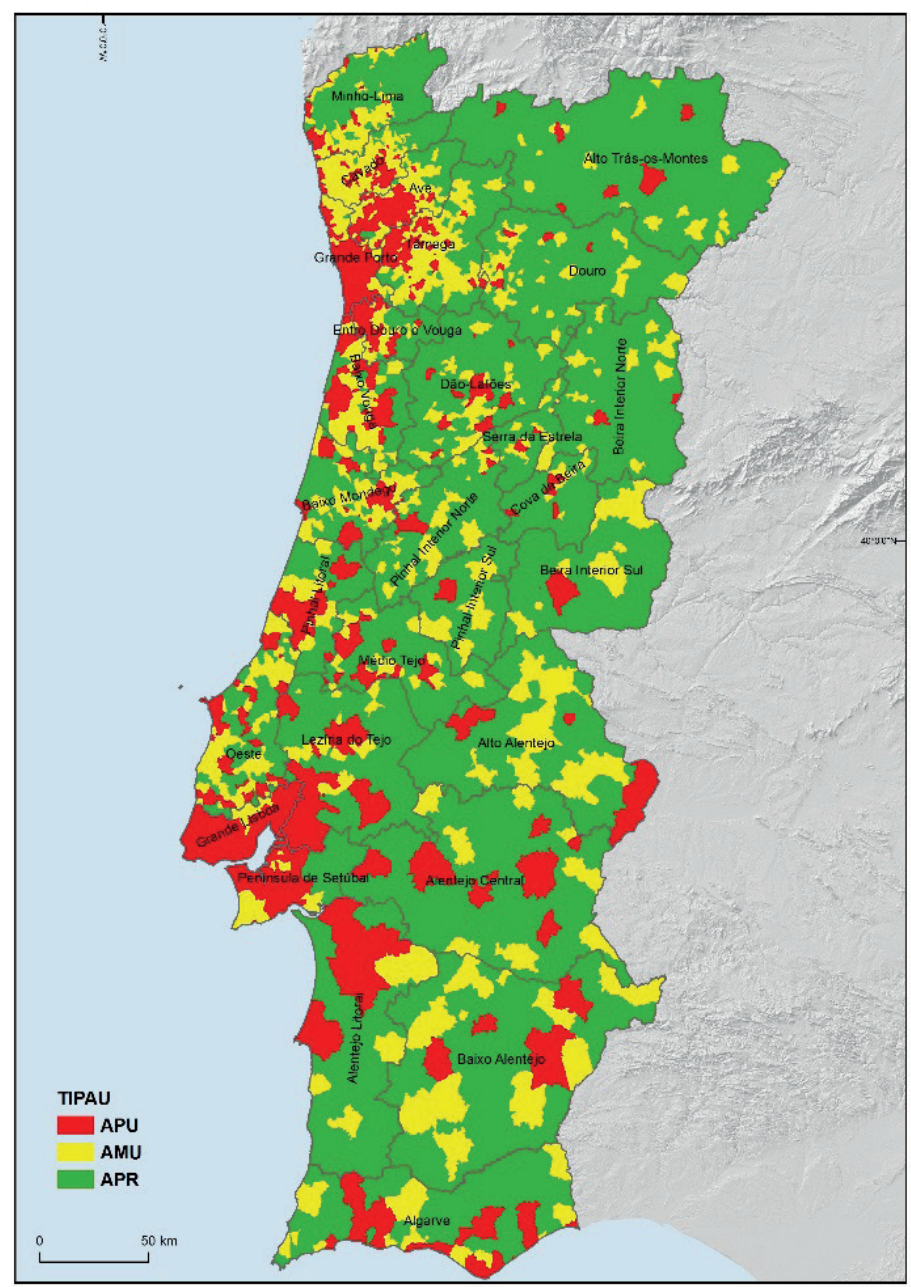

Fonte: INE, 2011. 
Os dados aqui apresentados referem-se ao recenseamento agrícola e, como tal, consideram apenas a atividade profissionalizada realizada em área com uma dimensão mínima, na generalidade dos casos de um hectare (INE, 2011a). A SAU inclui a classe horta familiar que compreende a cultura de produtos hortícolas, frutos e flores destinados ao autoconsumo (INE, 2011a).

No entanto, acontece que, em grande parte das áreas periurbanas e sobretudo urbanas, parte considerável da agricultura é informal, de muito pequena escala, e pratica-se em terrenos não pertencentes ao agricultor. Como tal, esse tipo de agricultura não é considerada pelas estatísticas oficiais. Exemplificando, no caso da cidade de Lisboa, a estatística do INE indicava cerca de 58 hectares de SAU em 2009. Contudo, os dados da Câmara Municipal de Lisboa ${ }^{2}$ revelavam a existência de cerca de 165 ha de área com hortas urbanas tanto de natureza espontânea e informal como de projeto institucional.

A partir de 2008, quando da crise econômica, a agricultura em contexto urbano, sobretudo nas duas Áreas Metropolitanas de Lisboa e Porto, intensificou-se em lotes para construção que foram abandonados, nas bermas das estradas, junto às linhas ferroviárias, em áreas incultas, muitas delas, da Reserva Agrícola Nacional (RAN) e da Reserva Ecológica Nacional (REN).

Foto 1 - Agricultura urbana no vale de Chelas (Cidade de Lisboa) em área de Estrutura Ecológica Municipal (Lisboa)

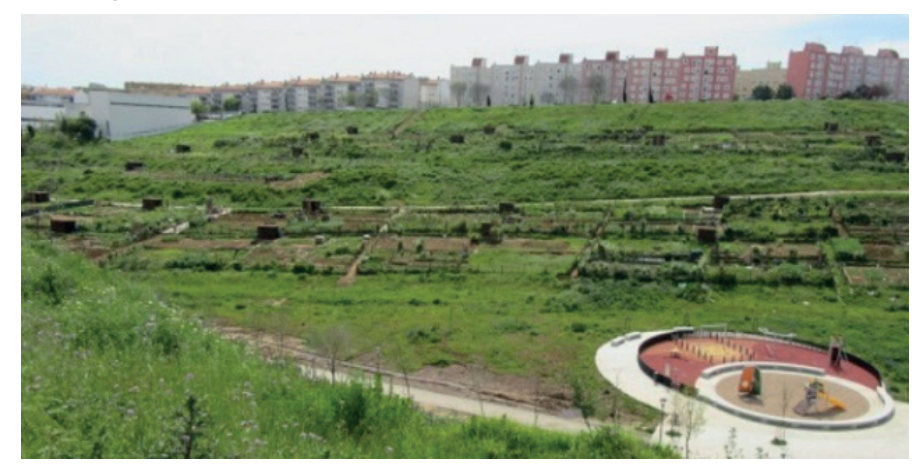

Fonte: Os autores, 2018.

2 Câmara Municipal de Lisboa, dados abertos. Disponível em: http://lisboaaberta.cm-lisboa.pt/ index.php/pt/. Acesso em jun. 2019. 
Foto 2 - Agricultura urbana junto ao Almada Forum em terrenos privados (Município de Almada, Área Metropolitana de Lisboa - Margem Sul)

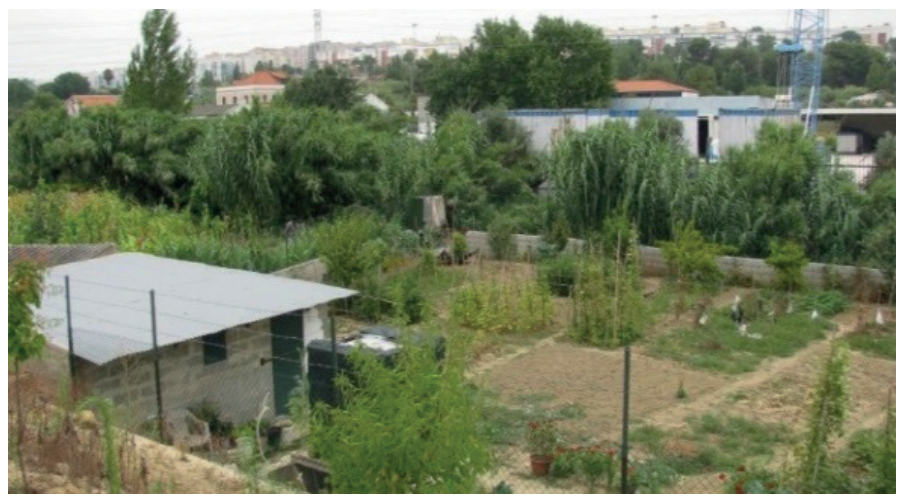

Fonte: Os autores, 2018.

Também a agricultura em contexto periurbano sofreu uma dinâmica socioespacial decorrente da crise. Embora essa situaçáo náo seja muito visível em termos quantitativos, nomeadamente, em aumento de SAU ou de número de exploraçóes (o recenseamento mais recente data de 2009), verificou-se por meio de entrevistas a vários atores dos municípios do Oeste e da Lezíria do Tejo para o projeto AGRIMET-MOD², a vinda de novos agricultores, na maior parte, jovens e empreendedores e, na sua maioria, filhos de antigos agricultores das regióes em estudo.

\section{Tipologia de relações agricultura e urbanização na RML}

Os estudos articulando cidade e agricultura são escassos, sobretudo em Portugal. No presente capítulo, para entender as configuraçóes socioespaciais em curso entre agricultura, urbanização e metropolização analisou-se a região metropolitana de Lisboa (RML).

A RML é composta por 41 municípios distribuídos por quatro NUTS III (Nomenclaturas de Unidades Territoriais): Grande Lisboa e Península de Setúbal (formando a Área Metropolitana de Lisboa - AML), Oeste e Lezíria do Tejo (mapa 2). Nessa área de cerca de 9.500 km², com um clima temperado de influência marítima, de relevo pouco acentuado, com uma vasta área de aluvião e com alguns elementos topográficos não excedendo os 670 metros, vivem 3.436.948 habitantes (INE, 2011). É uma região que 
conhece uma forte urbanização muito à custa dos espaços agrícolas, onde, entre 1990 e 2007, cerca de 29 mil hectares de solo agrícola foram transformados em área urbana (Abrantes et al., 2016). O mapa 2b e 2c, mostrando a densidade populacional e a percentagem de área construída, respetivamente, evidenciam claramente uma distribuição muito mais concentrada dos valores nos municípios de Lisboa e envolventes ribeirinhos. Em 2011, Lisboa possuía uma densidade populacional de $6.500 \mathrm{hab} / \mathrm{km}^{2}$ e uma percentagem de área construída de 98\%.

A atividade agrícola é muito diversificada nessa região, sendo mais intensiva nas NUTS III do Oeste e Lezíria do Tejo, onde predominam a produção de hortícolas, a fruticultura, assim como a vinha. O setor agroindustrial tem uma presença importante na região. Por meio dos mapas $2 \mathrm{~d}$ e $2 \mathrm{e}$ podemos verificar que a dimensão média das explorações (mapa $2 \mathrm{~d}$ ) aumenta à medida que nos afastamos do "core" metropolitano, com destaque para a margem sul do Tejo. O VAB por população empregada no setor primário (mapa 2e) segue o mesmo padrão, havendo uma tendência para maiores valores na NUT III Oeste e em alguns municípios da margem Sul (Benavente, Alcochete, Montijo e Moita). Lisboa apresenta valores elevados por concentrar as sedes das empresas agrícolas. 
Mapa 2 - Enquadramento da Área de Estudo (a); Densidade Populacional em 2011 (b); Percentagem de Área Construída em 2012 (c); Dimensão Média da Exploração em 2009 (d); Valor Acrescentado Bruto por população empregada no setor primário em 2009 (e)

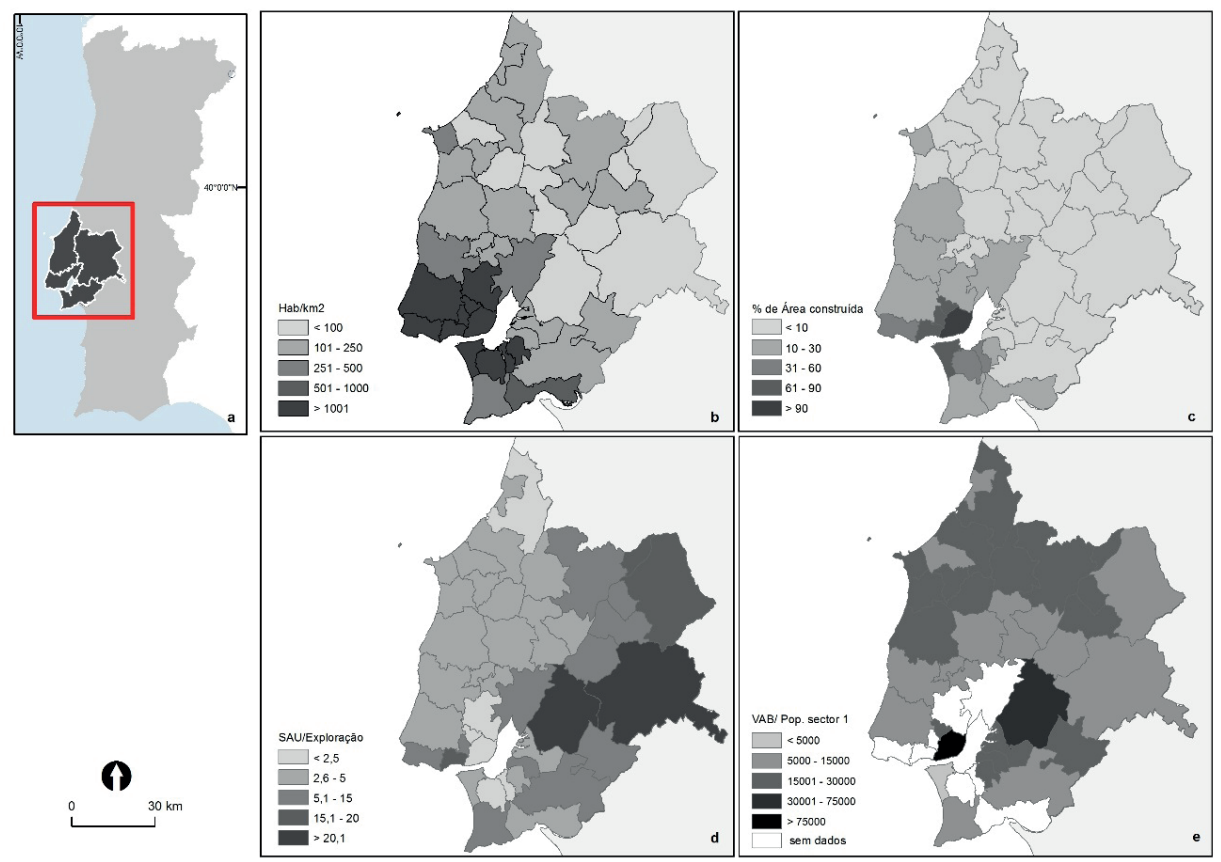

Fonte: INE, 2009 e 2011; DGT, 2012.

A opção pelo estudo dessa área mais alargada deve-se, por um lado, por essa grande regiáo englobar os municípios que compóem a área funcional de Lisboa, i.e., onde as deslocaçóes casa-trabalho são mais intensas (Marques da Costa e Marques da Costa, 2009), dando-nos conta dos processos de metropolização e periurbanização. Essa escolha é corroborada pelo esquema territorial do Plano de Ordenamento do Território da área metropolitana de Lisboa, que define três grandes espaços metropolitanos de interdependência com Lisboa (mapa 3). Por outro lado, engloba também a agricultura praticada no interior da cidade. A priori, encontraremos aqui os diferentes tipos de AUP. 
Mapa 3 - Esquema de Polarização Metropolitana do PROT-AML

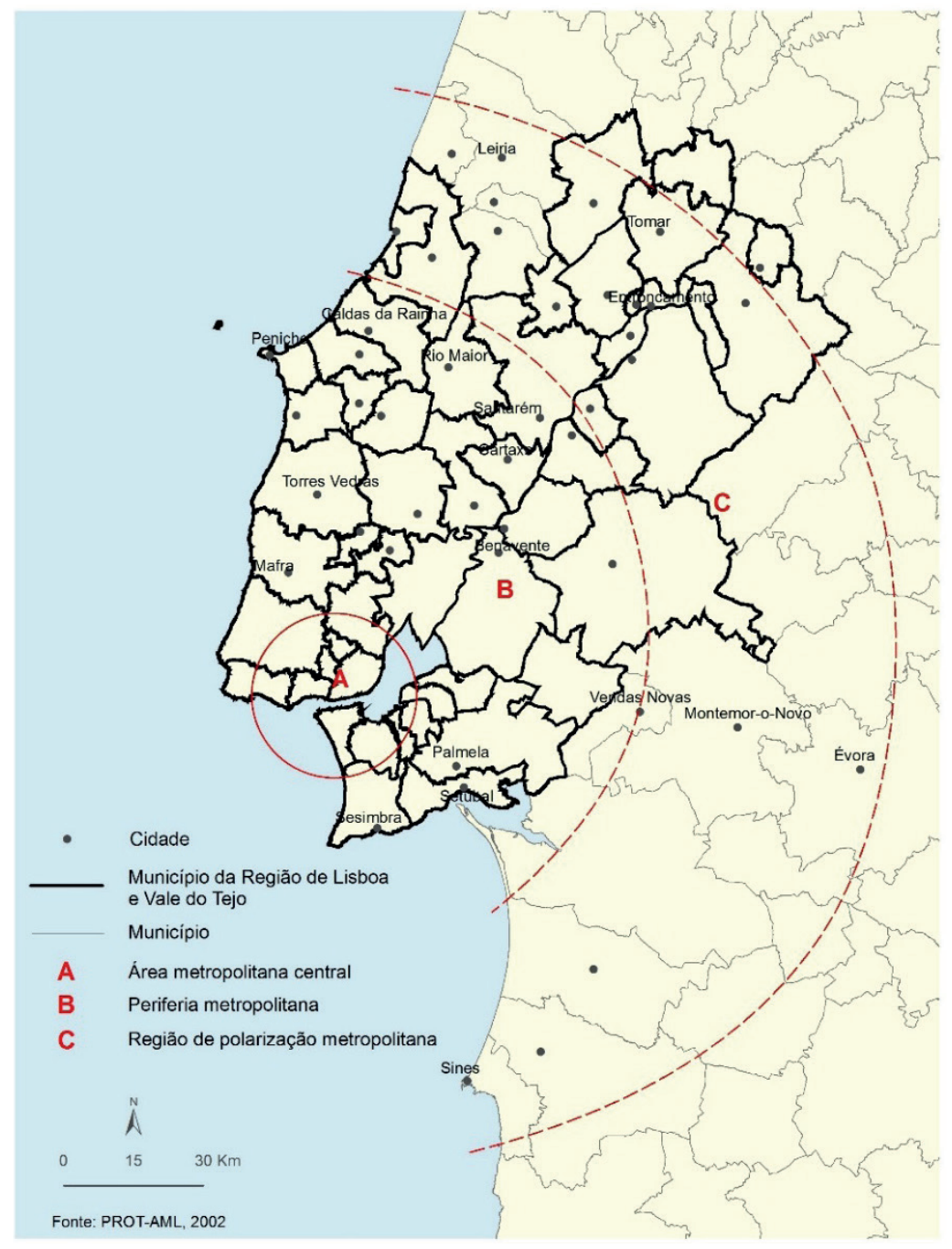

Fonte: CCDR-LVT, 2002.

Para cruzar as duas realidades, escolheu-se um conjunto de indicadores multidimensionais, permitindo medir que tipos de agricultura existem em contextos urbano e periurbano e como estes se relacionam com as dinâmicas de urbanização. 
A escolha de indicadores remete para a revisão bibliográfica desenvolvida no âmbito do projeto AGRIMET-MOD, ${ }^{3}$ sendo os mais comumente utilizados para medir essas realidades. Por sua vez, foi tida em conta a disponibilidade dos dados a uma determinada escala (município) e a possibilidade de analisar a dinâmica ao longo do tempo.

Foram, assim, definidos 36 indicadores organizados em três domínios de análise:

1. indicadores agrícolas, organizados em dois subdomínios (população agrícola e suas características: sexo, idade, nível de escolarização, tipo de mão de obra, exploraçóes e SAU: dimensão média da propriedade, natureza jurídica, tipo de cultura);

2. indicadores de uso e ocupação do solo (sobretudo relacionados com métricas de paisagem: \% e densidade de uso urbano e de uso agrícola, diversidade da paisagem, compacidade, distância ao uso urbano e agrícola e ao vizinho mais próximo);

3. indicadores demográficos e socioeconômicos gerais (escolarização, emprego, atividade profissional, deslocaçóes pendulares, densidade populacional, condiçóes de habitabilidade, tipo de edificado).

Os indicadores foram organizados numa base espacial em SIG no nível do município e para os anos 2011, variaçóes 1991-2001 e 2001-2011. O método utilizado para identificar e analisar as relaçôes de interdependência entre os indicadores foi a análise em componentes principais, e os grupos de municípios foram definidos a partir de uma análise de clusters. A análise em componentes principais consiste na transformação de um conjunto de variáveis iniciais correlacionadas num subconjunto de variáveis independentes, por combinação linear das variáveis originais, eliminando-se assim a redundância de informação, e a análise de clusters permite, posteriormente, agrupar os municípios pela proximidade estatística dos indicadores/componentes.

A partir dessas análises foram definidos e mapeados nove grupos de concelhos para a região metropolitana de Lisboa, como observado no mapa 4.

\footnotetext{
3 AGRIMET-MOD: Metropolitan Agriculture Spatial MODeling: contribution to the construction of an analysis model to support spatial planning and land use decision-making - financiado pela Fundação para a Ciência e a Tecnologia Portuguesa (PTDC/ATP-EUR/4910/2012). Para mais informaçôes, consultar o site do projeto, disponível em: http://agrimet.ul.pt/.
} 
Mapa 4 - Tipologia de configurações urbanas e agrícolas na Região Metropolitana de Lisboa

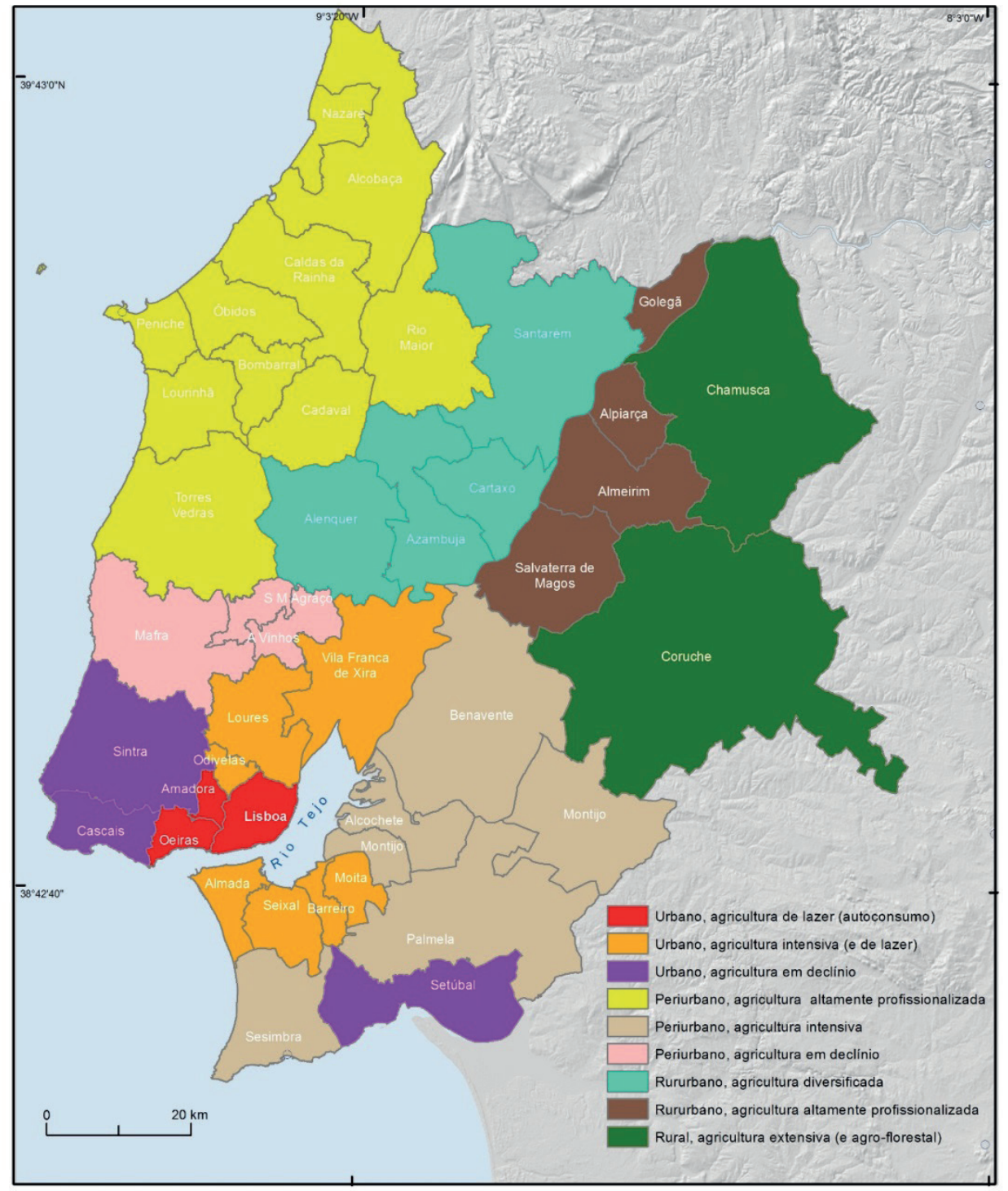

Fonte: AGRIMET-MOD, 2015.

Três grupos apresentam um perfil urbano, i.e., densidades de área urbana e populacional elevadas e uma população com atividade sobretudo no setor terciário. Nesse perfil mais urbano existem três padróes agrícolas: agricultura 
de lazer; agricultura intensiva, em simultâneo com agricultura de lazer; e agricultura em declínio.

Tabela 2 - Descrição do perfil agrícola urbano

\begin{tabular}{|c|c|c|}
\hline AGRICULTURA DE LAZER & $\begin{array}{l}\text { AGRICULTURA INTENSIVA } \\
\text { (E DE LAZER) }\end{array}$ & $\begin{array}{l}\text { AGRICULTURA EM } \\
\text { DECLÍNIO }\end{array}$ \\
\hline Lisboa, Amadora e Oeiras & $\begin{array}{l}\text { Odivelas, Loures, Vila Franca } \\
\text { de Xira, Almada, Seixal, } \\
\text { Barreiro, Moita }\end{array}$ & Cascais, Sintra e Setúbal \\
\hline $\begin{array}{l}\text { População agrícola } \\
\text { envelhecida, mão de obra } \\
\text { essencialmente familiar } \\
\text { e o principal rendimento } \\
\text { é exterior à exploração. } \\
\text { SAU é composta, } \\
\text { fundamentalmente, por } \\
\text { hortas familiares. } \\
\text { - Área urbana compacta e } \\
\text { densa. } \\
\text { - População residente com } \\
\text { elevado nível de formação, } \\
\text { desempregados a aumentar } \\
\text { e elevada percentagem } \\
\text { de residentes com } \\
\text { nacionalidade estrangeira. } \\
\text { - Oeiras apresenta um maior } \\
\text { peso de agricultores jovens } \\
\text { a partir do ano de } 2001 .\end{array}$ & $\begin{array}{l}\text { - População agrícola } \\
\text { com mão de obra } \\
\text { maioritariamente não } \\
\text { familiar a tempo parcial, } \\
\text { e o principal rendimento } \\
\text { é exterior à exploração. } \\
\text { A SAU é composta, } \\
\text { fundamentalmente, por } \\
\text { culturas temporárias, sendo } \\
\text { a exploração intensiva. } \\
\text { - As áreas agrícolas estão } \\
\text { fragmentadas. } \\
\text { - Há um aumento da } \\
\text { densidade populacional } \\
\text { com elevado número } \\
\text { de residentes com } \\
\text { nacionalidade estrangeira } \\
\text { (1991, 2001) e de } \\
\text { alojamentos precários. } \\
\text { Vila Franca de Xira tem } \\
\text { pouca agricultura e a mão } \\
\text { de obra é envelhecida. }\end{array}$ & $\begin{array}{l}\text { - População agrícola } \\
\text { envelhecida, em que } \\
\text { a principal fonte de } \\
\text { rendimento é exterior à } \\
\text { exploração. } \\
\text { - A densidade urbana } \\
\text { aumentou desde } 1990 \text {. }\end{array}$ \\
\hline
\end{tabular}

Fonte: AGRIMET-MOD, 2015.

Outros três grupos apresentam um perfil periurbano, i.e., têm uma variação da população positiva e um aumento da densidade desta, e a dimensão média da família é mais elevada em face das restantes tipologias. Também os movimentos pendulares são elevados. Dentro desses três grupos existem municípios onde a agricultura está em declínio, com agricultura intensiva e altamente especializada (caso do Oeste), ou ainda com agricultura intensiva, mas num contexto de forte pressão urbana. 
Tabela 3 - Descrição do perfil agrícola periurbano

\begin{tabular}{|c|c|c|}
\hline agricultura em declínio & $\begin{array}{c}\text { AGRICULTURA COM } \\
\text { FORTE ESPECIALIZAÇÃ̃O }\end{array}$ & $\begin{array}{c}\text { AGRICULTURA INTENSIVA } \\
\text { EM CONTEXTO DE FORTE } \\
\text { EXPANSÃO URBANA }\end{array}$ \\
\hline $\begin{array}{l}\text { Sobral de Monte Agraço, } \\
\text { Arruda dos Vinhos, Mafra }\end{array}$ & $\begin{array}{l}\text { Bombarral, Cadaval, } \\
\text { Alcobaça, Rio Maior, Nazaré, } \\
\text { Peniche, Torres Vedras e } \\
\text { Caldas da Rainha }\end{array}$ & $\begin{array}{l}\text { Sesimbra, Palmela, Alcochete, } \\
\text { Montijo e Benavente }\end{array}$ \\
\hline $\begin{array}{l}\text { - População agrícola em } \\
\text { declínio e essencialmente a } \\
\text { tempo parcial. } \\
\text { - Elevada percentagem de } \\
\text { paisagem agrícola. } \\
\text { - População residente a } \\
\text { aumentar. }\end{array}$ & $\begin{array}{l}\text { - População agrícola com } \\
\text { mão de obra não familiar a } \\
\text { tempo completo. } \\
\text { - Crescimento significativo } \\
\text { da produção de hortícolas } \\
\text { e do arrendamento } \\
\text { agrícola entre } 2001 \text { e } 2011 \text {. } \\
\text { - População residente a } \\
\text { aumentar desde } 2001 \text {. }\end{array}$ & $\begin{array}{l}\text { - População agrícola } \\
\text { envelhecida e o trabalho } \\
\text { agrícola é essencialmente } \\
\text { não familiar. Aumento } \\
\text { da dimensão média da } \\
\text { exploração agrícola. } \\
\text { - Forte crescimento da } \\
\text { população residente e do } \\
\text { número de elementos por } \\
\text { família, mas também da sua } \\
\text { qualificação e emprego. } \\
\text { - Alcochete, Palmela e } \\
\text { Sesimbra são compostas } \\
\text { maioritariamente por } \\
\text { culturas temporárias. }\end{array}$ \\
\hline
\end{tabular}

Fonte: AGRIMET-MOD, 2015.

Seguidamente, dois grupos apresentam um perfil rurbano, ou seja, munícipios com alguma relevância dos indicadores de população, dos movimentos pendulares, da população com ensino superior, da dimensão média da exploração e da percentagem de área agrícola. O primeiro apresenta uma agricultura diversificada, e o segundo, uma agricultura mais profissionalizada.

\section{Tabela 4 - Descrição do perfil agrícola rurbano}

agricultura diversificada

\begin{tabular}{ll}
\hline Alenquer, Azambuja, Cartaxo, Santarém & \multicolumn{1}{c}{ PROFISSIONALIZAÇão } \\
\hline - População agrícola com mão de obra & $\begin{array}{c}\text { Almegã, Alpiarça, Salvaterra de } \\
\text { Magos }\end{array}$ \\
$\begin{array}{l}\text { familiar significativa. Explorações com } \\
\text { grande produtividade, com registro de }\end{array}$ & $\begin{array}{l}\text { - Explorações muito produtivas (sobretudo } \\
\text { depois de 2001). }\end{array}$ \\
$\begin{array}{l}\text { um aumento de pequenos agricultores. A } \\
\text { produção é variada. }\end{array}$ & $\begin{array}{l}\text { Fragmentação das manchas de solo } \\
\text { agrícola. Aumento da população. Taxa } \\
\text { de desemprego elevada e aumento da } \\
\text { - Diversidade de uso/ocupação do solo. }\end{array}$ \\
$\begin{array}{l}\text { - Ligeiro aumento da densidade } \\
\text { populacionão ativa nos serviços entre 2001- }\end{array}$ & 2011. \\
\hline
\end{tabular}
PROFISSIONALIZAÇÃO

gã, Alpiarça, Salvaterra de

AGRICULTURA INTENSIVA COM FORTE

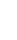


Finalmente, um último perfil, o rural, em que predominam as grandes exploraçóes agrícolas e agroflorestais. Esse grupo é composto pelos municípios de Chamusca e Coruche e caracterizam-se por uma redução da mão de obra agrícola familiar, um aumento da dimensão média das exploraçôes e uma paisagem com grandes manchas agrícolas e áreas urbanas distantes entre si.

Constata-se que existe uma diversidade enorme na RML, com territórios mais urbanos, onde há agricultura de lazer, de subsistência, intensiva e profissionalizada e agricultura em declínio. E territórios periubanos e rurbanos, onde a agricultura altamente intensiva, muitas vezes não sustentável do ponto de vista ambiental, está lado a lado com municípios onde a agricultura está em declínio devido à forte pressão urbana.

Essa diversidade é uma riqueza, mas também é um desafio do ponto de vista da salvaguarda, proteção, integração e ordenamento dos espaços.

\section{Como integrar agricultura e urbanização na política de ordenamento na RML?}

No final do século XX, a questão da dispersão urbana com o consumo excessivo de solo natural e agrícola altamente produtivo e a questáo do desenvolvimento urbano sustentável fizeram emergir o debate conceitual e político em nível global sobre a importância da agricultura para a cidade e como esta e a cidade deveriam estar mais articuladas. Já, na década 2010, a percepção da vulnerabilidade dos sistemas globais, seja por via das alteraçóes climáticas, seja pela dependência excessiva das oscilaçôes do preços dos mercados, veio reforçar ainda mais essa importância (Curry et al., 2014).

É inegável o reconhecimento global sobre a relevância da agricultura em contextos urbano e periurbano (FAO, 2015). Contudo, de acordo com Curry et al. (2014), escasseia uma agenda concreta para a AUP nas orientaçôes de política da Uniâo Europeia (UE). Um dos argumentos apontados pelo mesmo autor é que esta abrange uma perspectiva tão multidimensional que acaba por ser difícil de integrar nas orientaçóes de política. A AUP surge pontualmente em estudos e recomendaçóes de algumas direçóes gerais, com particular destaque para (Curry et al., 2014): i) a Direção Geral do Ambiente, que releva as questóes da agricultura para a infraestrutura verde das cidades e para o desenvolvimento urbano sustentável; ii) a Direção Geral da Política Regional e Urbana, em que a questão da agricultura é considerada para assegurar a contenção do urbano, a preservação dos espaços verdes e o reforço das 
relaçôes entre cidades e espaços rurais; e iii) a Direção Geral da Agricultura e Desenvolvimento Rural, em que, apesar da Política Agrícola Comum (PAC) negligenciar a agricultura na cidade, há uma preocupação pelas cadeias de valor locais e regionais.

A política Europeia considera a agricultura numa perspectiva setorial, de desenvolvimento dos espaços rurais e ambientais como forma de preservação dos espaços verdes da expansão urbana. Em Portugal, a situação não é muito diferente da UE, pois esta orienta grande parte da política desenvolvida pelos países membros.

O desenvolvimento agrícola português faz-se por meio de políticas setoriais com impacto espacial representadas nos programas para o desenvolvimento agrícola e rural e no seu financiamento comunitário (e.g. via PAC, i.e. Política Agrícola Comum e Programa Leader, i.e., um programa comunitário para a promoção de açóes para o desenvolvimento da economia rural).

Em termos de política de urbanismo e ordenamento do território, a agricultura é, desde meados dos anos 1990, considerada numa ótica de zonamento dos espaços por intermédio da figura do Plano Diretor Municipal (PDM), sendo a RAN (Reserva Agrícola Nacional) e a REN (Reserva Ecológica Nacional) duas figuras de integração obrigatória nesses planos. A RAN preserva os solos com maior aptidão, proibindo a sua construção; a REN preserva os solos com maior valor e sensibilidade ecológica; e os Planos Diretores Municipais (PDM) regulam a ocupação, o uso e a transformação do solo municipal.

No final do milênio, a Lei de Bases da Política de Ordenamento do Território e do Urbanismo (1998) e o Regime Jurídico dos Instrumentos de Gestáo do Território (1999) definiram que o urbanismo e o ordenamento do território devem ser articulados em três escalas: nacional, regional e municipal. As escalas nacionais e regionais passam a definir as estratégias para a escala municipal, de acordo com as linhas orientadoras europeias, e o país passa a dispor de um sistema articulado entre as diretrizes estratégicas e setoriais de âmbito nacional e regional e o sistema estratégico e regulamentar local.

O Programa da Política Nacional de Ordenamento do Território (PNPOT), aprovado em 2007 e alterado em 2018, é o instrumento mais importante desse sistema, pois define o modelo de organização do território nacional. Os programas setoriais devem estar articulados com este, assim como os programas regionais e os regulamentos locais (e.g. os PDM). O modelo de organização do território do PNPOT defende o policentrismo para fazer face 
aos desequilíbrios estruturais do sistema urbano nacional. Defende ainda a contenção urbana e a densificação. Nesse documento, a agricultura é tida em conta para manter os espaços livres da urbanização e para conter a fragmentação urbana. Os documentos de escala regional, os Planos Regionais de Ordenamento do Território (PROT), seguem essas linhas orientadoras e, nos seus modelos de organização regional, mantém-se a ótica de salvaguarda dos espaços agrícolas.

Na Região Metropolitana de Lisboa existem dois PROT em vigor: o PROT para a região Oeste e Vale do Tejo (PROT-OVT), aprovado em 2009, e o PROT para a Área Metropolitana de Lisboa (PROT-AML), de 2002. O primeiro defende a criação e a preservação de zonas agrícolas prioritárias e a delimitação de zonas preferenciais para o desenvolvimento agrícola a realizar pelos municípios. O segundo defende uma maior competitividade da agricultura e também o papel desta na salvaguarda dos solos em face das pressóes urbanísticas. Por sua vez, todos os municípios têm PDM em vigor, a maior parte deles há mais de 20 anos, alguns estão em processo de revisão, e todos contemplam o zonamento dos espaços agrícolas e agroflorestais.

Contudo, apesar de haver uma estratégia para a agricultura, um zonamento e uma proteção legal dos espaços agrícolas, a verdade é que estes foram sendo urbanizados. Os estudos de Abrantes et al. (2016) para a RML mostram que, entre 1990 e 2007, 14\% do solo classificado em PDM como agrícola foi urbanizado e que $21 \%$ do solo classificado como RAN e REN também foi urbanizado, revelando um não cumprimento de objetivos.

Desde logo, a dificuldade em transpor as orientaçóes estratégicas para a prática, a não ser pela via do zonamento. Mas o zonamento per si não é suficiente para a proteção e usabilidades desses espaços, já que o urbano avançou largamente sobre estes. Por sua vez, as orientaçóes estratégicas mais recentes estão desfasadas diante da antiguidade dos PDM; são também vagas e pouco integradoras da importância da agricultura para as cidades e metrópoles. Numa conferência em Coimbra, ${ }^{4}$ o professor Jorge Gaspar criticava o fato do PNPOT náo discutir o planeamento alimentar das cidades e regióes. A visão sobre agricultura permanece setorial e, como tal, não é integrada ao planeamento municipal.

4 "Alimentação, geografia e ordenamento do território", em I Encontro de Estudantes de Geografia, 20 de fevereiro de 2019, Coimbra. 
Cruzando-se a tipologia obtida anteriormente (mapa 4) com as opções de política de ordenamento do território e urbanismo, assiste-se a duas realidades distintas. Em municípios mais urbanos, e caso a caso, existe uma preocupação pela agricultura urbana com o proliferar de projetos para desenvolvimento de hortas municipais no interior da cidade. Lisboa é o exemplo paradigmático com a integração das hortas no PDM em revisão, revelando uma preocupação com a estrutura verde da cidade. Nos espaços periurbanos, rurbanos e mesmo rurais da RML, o que prevalece é a política setorial para a agricultura. Ora, esses espaços têm sido problemáticos do ponto de vista da perda de solo agrícola (Abrantes et al., 2016).

Como integrar agricultura e urbanização nesses territórios? Em Portugal, existe consagrada na lei de bases a figura do programa ou plano intermunicipal (PIOT), contudo não é aplicada. Essa figura considera um ordenamento do território pensado à escala intermunicipal, permitindo o diálogo e a participação em torno de um projeto comum. A França é o exemplo mais emblemático onde essa opção - os SCOT (Schèmas de Cohérence Territoriale) - tem funcionado bem para o desenvolvimento da agricultura em contexto periurbano (Duvernoy e Paradis, 2016; Perrin et al., 2016). É, aliás, o entendimento de alguns autores que a salvaguarda e o reforço da agricultura em contexto periurbano se faça pela via do projeto (planeamento alimentar, corredor metropolitano agrícola, circuitos de venda direta etc.) e da instauração de uma política de ordenamento mais participativa (Loudiyi et al., 2017).

Existindo a figura PIOT em Portugal, há que utilizá-la, articulando o financiamento comunitário setorial com a política espacial, aumentando ao mesmo tempo a sensibilização e a formação dos técnicos de planeamento, da agricultura e de desenvolvimento rural e os dirigentes políticos para o reforço da relevância da agricultura a essa escala. Uma tipologia como a obtida denota a diversidade de espaços e como pode dar orientações para que os territórios possam funcionar em torno de uma problemática e projeto comuns. A RML, com os seus diversos territórios, poderia funcionar como projeto piloto para o desenvolvimento de PIOTs em torno da integração "agriurbana". 


\section{Considerações finais}

O objetivo deste capítulo de livro foi de analisar a relação entre urbanização, metropolização e agricultura, com particular destaque para a região metropolitana de Lisboa (RML). A partir da análise desses conceitos, desenvolveu-se uma tipologia para medir as configuraçóes e as dinâmicas espaciais entre agricultura e urbanização. Adicionalmente, mostrou-se como as políticas espaciais, nomeadamente de urbanismo e ordenamento do território, estão a enquadrar a agricultura nesses contextos urbano e periurbano.

Verificou-se que o discurso sobre a agricultura em contextos urbano e periurbano tem ganhado relevância nos últimos anos, sobretudo numa ótica de sustentabilidade. Os governos estão mais sensíveis para essas questôes, embora, em termos práticos ou operacionais, as políticas de ordenamento do território e o urbanismo não têm tido a flexibilidade suficiente para articular e preservar a agricultura na cidade, mas sobretudo na periferia.

A tipologia desenvolvida para a RML mostra dinâmicas e configuraçóes diversas no que concerna a agricultura e urbanização. Há uma agricultura de lazer, subsistência e profissional em contexto mais urbanizado, mas o mesmo também se observa em contexto mais periférico. E há uma agricultura em declínio em áreas onde a expansão urbana é mais intensa. Esses talvez sejam os territórios mais problemáticos do ponto de vista da perda da "cultura" agrícola. Partindo dessa análise, propóe-se que a questão de articulação da agricultura e urbanização possa ser entendida, à escala intermunicipal, em torno de projetos e territórios mais próximos.

\section{Referências}

ABRANTES, Patrícia. La métropolisation au Portugal: processus et politiques spatiales. Lisboa: Universidade de Lisboa, Centro de Estudos Geográficos, 2011. Disponível em: https://repositorio.ul.pt/handle/10451/38909. Acesso em: 30 jul. 2019. et al. "Compliance of land cover changes with municipal land use planning: evidence from the Lisbon metropolitan region (1990-2007)". Land Use Policy, v. 51, p. 120-34, 1 fev. 2016. Disponível em: https:/www.sciencedirect.com/science/ article/abs/pii/S0264837715003348. Acesso em: 30 jul. 2019.

AUBRY, Christine e KEBIR, Leila. "Shortening food supply chains: a means for maintaining agriculture close to urban areas? The case of the French metropolitan area of Paris". Food Policy, v. 41, p. 85-93, 1 ago. 2013. Disponível em: https:// 
www.sciencedirect.com/science/article/abs/pii/S0306919213000456. Acesso em: 30 jul. 2019.

BAUER, Gérard e ROUX, Jean-Michel. La rurbanisation ou la ville éparpillée. Paris: Éditions du Seuil, 1976.

BERRY, Brian J. L. Do variations in urban form affect environmental quality? Final report of the project land use forms and the environment. University of Chicago, 1974.

CANCELA, Jorge Manuel Frazão. A agricultura urbana na operacionalização da estrutura ecológica municipal: o estudo de caso do parque agricola da Alta de Lisboa (tese). Universidade de Lisboa, 2014. Disponível em: https://www.repository.utl. pt/handle/10400.5/7183. Acesso em: 30 jul. 2019.

CURRY, N. et al. "Urban agriculture and the policies of the European Union: the need for renewal". Spanish Journal of Rural Development, v. 5, n. 1, p. 91-106, 2014. Disponível em: http://www.sjruraldevelopment.org/en/journal/390/urban-agriculture-and-the-policies-of-the-european-union-the-need-for-renewal/. Acesso em: 30 jul. 2019.

DELGADO, Cecília. "Contrasting practices and perceptions of urban agriculture in Portugal”. International Journal of Urban Sustainable Development, v. 10, n. 2, p. 170-85, 4 maio 2018. Disponível em: https://www.tandfonline.com/doi/full/ 10.1080/19463138.2018.1481069. Acesso em: 30 jul. 2019.

DÉZERT, Bernard et al. La périurbanisation en France. SEDES, 1991.

DUVERNOY, Isabelle e PARADIS, Sylvie. "Les producteurs de grandes cultures dans le périurbain toulousain. Quelle insertion dans les territoires de la demande urbaine ?". Cybergeo: European Journal of Geography, Espace, Societé, Territorire, n. 768, 26 jan. 2016. Disponível em: http://journals.openedition.org/cybergeo/27478. Acesso em: 30 jul. 2019.

EEA. Urban Sprawl in Europe: the ignored challenge. EEA Report n. ${ }^{\circ}$ 10/2006. Copenhagen: [s.n.], 2006. Disponível em: http://www.eea.europa.eu/publications/ eea_report_2006_10.

EUROSTAT. Urban Europe: statistics on cities, towns and suburbs. Statistica ed. Luxembourg: Publications Office of the European Union, 2016. Disponível em: https:// ec.europa.eu/eurostat/statistics-explained/index.php/Urban_Europe___statistics_on_cities,_towns_and_suburbs. Acesso em: 30 jul. 2019.

FAO. FAO's role in urban agriculture. Disponível em: http://www.fao.org/urban-agriculture/en/.

HERVOUËT, Vincent. La sémantique périurbaine : ou comment se repérer dans un dédale de mots et d'expressions. Nantes: CESTAN - Université de Nantes, 2001. Disponível em: http://eso.cnrs.fr/_attachments/n-15-mars-2001-travaux-et-documents/14VHervouet.pdf?download=true. Acesso em: 30 jul. 2019.

INE. Recenseamento Agricola 2009. Lisboa: Instituto Nacional de Estatística, 2011a. 
XV Recenseamento Geral da População. Lisboa: Instituto Nacional de Estatística, $2011 \mathrm{~b}$.

INE-DGOTDU. Tipologia das Áreas Urbanas. Lisboa: INE-DGOTDU, 1998.

LARDON, Sylvie et al. Peri-urbanisation and peri-urban agriculture: issues and proposals. 2009.

LIN, Brenda B. et al. "The future of urban agriculture and biodiversity-ecosystem services: challenges and next steps”. Basic and Applied Ecology, v. 16, n. 3, p. 189201, 1 maio 2015. Disponível em: https://www.sciencedirect.com/science/article/ pii/S1439179115000067. Acesso em: 30 jul. 2019.

LOUDIYI, Salma et al. "The Integration Between Mediterranean Cities and Agriculture in Local Projects. A Conceptual Framework". Springer, Cham, 2017, p. 129-43. Disponível em: http://link.springer.com/10.1007/978-3-319-710372_8. Acesso em: 30 jul. 2019.

MAGALHÁES, Manuela Raposo. "Paisagem urbana e interface urbano-rural”. In: ALVES, A. et al. (orgs.). Paisagem. Lisboa: DGOTDU, 1994, p. 97-118.

MARQUES DA COSTA, Eduarda. "Cidades médias: contributos para a sua definição". Finisterra, v. 37, n. 74, 13 dez. 2002. Disponível em: http://revistas. rcaap.pt/finisterra/article/view/1592. Acesso em: 30 jul. 2019.

"As pequenas e médias cidades portuguesas: dinâmicas demográficas e funcionais nos últimos quarenta anos". In MATURANA, Francisco et al. (eds.). Sistemas urbanos y ciudades medias en Iberoamérica. Santiago: Pontificia Universidad Católica de Chile, 2017, p. 258-300. (Serie GEOlibros, n. 26).

e MARQUES DA COSTA, Nuno. "Mobilidade e forma urbana: o caso da Área Metropolitana de Lisboa”. Sociedade e Território, v. 42, p. 75-85, 2009.

MARQUES DA COSTA, Nuno. Mobilidade e transporte em áreas urbanas: o caso da Área Metropolitana de Lisboa (tese). Universidade de Lisboa, 2017. Disponível em: https://repositorio.ul.pt/handle/10451/556. Acesso em: 30 jul. 2019.

MERLIN, Pierre. L'exode urbain, de la ville à la campagne. Edição 5303 de Études de la Documentation française. Paris: Documentation Française, 2009.

e CHOAY, Françoise. Dictionnaire de l'urbanisme et de l'aménagement. Paris: Presses Universitaires de France, 1996.

MOINDROT, Claude. "Les systemes agraires". In BAILLY, Antoine et al. (orgs.). Encyclopédie de la géographie. Paris: Éditions Economica, 1992, p. 463-87.

MOK, Hoi-Fei et al. "Strawberry fields forever? Urban agriculture in developed countries: a review”. Agronomy for Sustainable Development, v. 34, n. 1, p. 21-43, 30 jan. 2014. Disponível em: http://link.springer.com/10.1007/s13593-0130156-7. Acesso em: 30 jul. 2019.

MOUGEOT, Luc J. A. AGROPOLIS: the social, environmental and political dimensions of urban agriculture. Londres: Earthscan, 2005. Disponível em: https:// 
idl-bnc-idrc.dspacedirect.org/bitstream/handle/10625/28341/IDL-28341.pdf? sequence $=47 \&$ isAllowed $=y$. Acesso em: 30 jul. 2019.

OPITZ, Ina et al. "Contributing to food security in urban areas: differences between urban agriculture and peri-urban agriculture in the Global North". Agriculture and Human Values, v. 33, n. 2, p. 341-58, 28 jun. 2016. Disponível em: http://link. springer.com/10.1007/s10460-015-9610-2. Acesso em: 30 jul. 2019.

PASCALE, Alfonso. "Coi concetti di urbano e rurale non si riscopre il senso del luogo". Agriregionieuropa, v. 12, n. 45, p. 16, 2009. Disponível em: https:// agriregionieuropa.univpm.it/it/content/article/31/18/coi-concetti-di-urbano-erurale-non-si-riscopre-il-senso-del-luogo.

PAÜL, Valerià e MCKENZIE, Fiona Haslam. "Peri-urban farmland conservation and development of alternative food networks: insights from a case-study area in metropolitan Barcelona (Catalonia, Spain)". Land Use Policy, v. 30, n. 1, p. 94105, 1 jan. 2013. Disponível em: https://www.sciencedirect.com/science/article/ abs/pii/S0264837712000294. Acesso em: 30 jul. 2019.

PEIXOTO, João. "O crescimento da população urbana e a industrialização em Portugal”. Revista Crítica de Ciências Sociais, v. 22, p. 101-13, 1987.

PERRIN, Coline et al. "La gouvernance du foncier agricole périurbain : entre planification urbaine et projets de développement". Revue d'Économie Régionale \& Urbaine, n. 4, p. 713-36, 2016. Disponível em: http://www.cairn.info/revue-deconomie-regionale-et-urbaine-2016-4-page-713.htm. Acesso em: 30 jul. 2019.

SÁ MARQUES, Teresa. Portugal na transiçâo do século : retratos e dinâmicas territoriais. 1. ed. Porto: Afrontamento, 2004.

SANTO, Raychel et al. "Vacant lots to vibrant plots: a review of the benefits and limitations of urban agriculture". Baltimore: Johns Hopkins Center for a Livable Future, 2016. Disponível em: https://www.jhsph.edu/research/centers-and-institutes/johns-hopkins-center-for-a-livable-future/_pdf/research/clf_reports/ urban-ag-literature-review.pdf. Acesso em: 30 jul. 2019.

TELLES, Gonçalo Ribeiro. "Paisagem global”. In ALVES, A. et al. (orgs.). Paisagem. Lisboa: DGOTDU, 1994, p. 31-45.

TORNAGHI, Chiara. "Critical geography of urban agriculture". Progress in Human Geography, v. 38, n. 4, p. 551-67, 2014. Disponível em: https://journals.sagepub. com/doi/pdf/10.1177/0309132513512542. Acesso em: 30 jul. 2019.

ZASADA, Ingo. "Multifunctional peri-urban agriculture: a review of societal demands and the provision of goods and services by farming". Land Use Policy, v. 28, n. 4, p. 639-48, 1 out. 2011. Disponível em: https://www.sciencedirect.com/science/ article/abs/pii/S0264837711000184. Acesso em: 30 jul. 2019. 


\section{Capítulo 9 \\ Transporte e Cidades Saudáveis: realidades, políticas e intervenções em Portugal}

Nuno Marques da Costa

Ana Louro

Eduarda Marques da Costa

\section{Introdução}

O transporte é um elemento central das cidades, pois permite o movimento de pessoas e de bens e, simultaneamente, ocupa uma superfície significativa da própria cidade (Thomson, 1977). As elevadas densidades de residentes, emprego e atividades econômicas, que caracterizam as áreas urbanas, têm promovido o consumo e a procura de transporte, sendo que o seu atual modelo de procura, centrado no transporte individual motorizado, tem gerado impactos negativos, tais como congestionamento, sinistralidade rodoviária, poluição atmosférica e sonora, excessivo consumo de recursos naturais finitos, entre outros. Por outro lado, vários movimentos de planeamento urbano têm procurado o desenvolvimento de territórios e comunidades mais sustentáveis, inclusivas e, dessa forma, proporcionar melhor qualidade de vida aos seus residentes. Um deles, o Movimento Cidades Saudáveis, considera que a saúde dos indivíduos é também influenciada pela sua envolvente, ou seja, pelas condições de vida, de trabalho, de ambiente físico e socioeconômico, sendo que o transporte, a acessibilidade e a mobilidade por ele proporcionadas têm constituído um elemento central para a concretização daqueles objetivos.

Da relação entre esses dois domínios - transporte e cidades saudáveis - surgem frequentemente a debate três problemas: a motorização excessiva, a sinistralidade rodoviária e a poluição causada pelo transporte. O presente 
capítulo tem como objetivo compreender de que forma aqueles problemas têm sido considerados nas políticas e intervenções no âmbito do Projeto Cidades Saudáveis em Portugal.

Este capítulo estrutura-se em cinco partes. Após esta introdução, na primeira parte, é discutida a relação entre o transporte e a Cidade Saudável. $\mathrm{Na}$ segunda, apresenta-se um breve olhar sobre a realidade em Portugal Continental relativo aos três tópicos: motorização, sinistralidade e poluição. $\mathrm{Na}$ terceira, discutem-se as orientaçóes de alguns instrumentos de política nacional. $\mathrm{Na}$ quarta, são apresentados alguns exemplos de intervençóes relacionadas com o transporte e enquadradas pelo Projeto Cidades Saudáveis. Na quinta e última parte, são apresentas as conclusôes.

\section{O transporte e a Cidade Saudável}

O transporte permite que o espaço entre dois ou mais pontos seja transposto num determinado período de tempo, respondendo às necessidades e motivaçóes dos indivíduos e sendo dependente da distância, do modo de transporte e de diferentes constrangimentos físicos e humanos (Rodrigue et al., 2006; Holden, 2007). Entre os vários modos de transporte, o automóvel, ícone do século XX e um dos principais produtos de consumo individual, imagem do estatuto social, liberdade e conforto, tem vindo a alterar a procura de transporte, bem como tem impactado no desenvolvimento urbano (Melo dos Santos, 2015). O aumento da sua utilizaçâo para as deslocaçôes urbanas tem conduzido à elevada quota que o transporte individual motorizado detêm na repartição modal de muitas das cidades mundiais. Essa crescente utilização é vista como um dos problemas das áreas urbanas, acarretando uma grande diversidade de impactos negativos e condicionando a sustentabilidade do sistema de transporte (Black, 2010; Banister, 2005; Holden, 2007; United Nations, 2016; Marques da Costa, 2007).

Uma das consequências negativas da excessiva motorização é a poluição atmosférica e os seus impactos diretos (Litman, 2008; Pacione, 2009). De acordo com a quadro1, é vasto o número de efeitos que alguns dos poluentes associados ao tráfego e ao quotidiano das áreas urbanas provocam na saúde, particularmente no sistema respiratório, sublinhando-se efeitos mais acentuados em grupos sociais mais sensíveis, como crianças e idosos. 
O transporte na Europa é responsável por cerca de um quarto das emissóes de gases com efeito de estufa (GEE) (26,7\%) e por cerca de um terço das emissões de CO2 (32,1\%). É o modo rodoviário o principal responsável por $72 \%$ das emissóes associadas ao transporte de GEE e de CO2 (EU, 2018). Assim, torna-se fundamental monitorizar a qualidade do ar pela sua influência na prevalência de doenças respiratórias, cardiovasculares, neurológicas e cancerígenas (Black, 2010; Rodrigue et al., 2006).

A sinistralidade rodoviária constitui outro dos elementos relevantes que se associam ao aumento da motorização. Como referiu Black (2010), um sistema de transporte que contribua para a mortalidade dos seus utilizadores apresenta problemas de sustentabilidade. As causas da sinistralidade são várias, desde o erro humano devido à falta de experiência, condução agressiva, excesso de velocidade, cansaço ou distração, ou à condução sob influência de álcool ou drogas, até a fatores ambientais, como fenômenos atmosféricos, chuva extrema, neve ou nevoeiro. Contam-se ainda fatores infraestruturais relacionados com as condiçôes e o perfil das vias, sinalização e semaforização ou com as condições técnicas dos veículos (Rodrigue et al., 2006; Black, 2010; Pacheco, 2004).

Quadro 1 - Fontes e efeitos dos principais poluentes atmosféricos $\left(\mathrm{CO}, \mathrm{NO}_{2}\right.$, $\mathrm{O}_{3}, \mathrm{PM}_{10}$ e $\mathrm{PM}_{25}$ )

\begin{tabular}{|c|c|c|}
\hline Poluente & Fontes & Efeitos \\
\hline Monóxido de Carbono (CO) & $\begin{array}{l}\text { Tráfego } \\
\text { Indústria }\end{array}$ & $\begin{array}{l}\text { Afeta sistema cardiovascular e nervoso: } \\
\text { - asfixia } \\
\text { - tonturas, sonolência, dores de cabeça }\end{array}$ \\
\hline Dióxido de Azoto $\left(\mathrm{NO}_{2}\right)$ & $\begin{array}{l}\text { Tráfego } \\
\text { Indústria }\end{array}$ & $\begin{array}{l}\text { Afeta sistema respiratório, especialmente } \\
\text { de crianças: } \\
\text { - lesões nos brônquios e alveolos } \\
\text { pulmonares } \\
\text { - aumento da reatividade a alergênicos } \\
\text { naturais } \\
\text { - redução da visibilidade } \\
\text { - acidificante }\end{array}$ \\
\hline Ozônio $\left(\mathrm{O}_{3}\right)$ & & $\begin{array}{l}\text { Afeta sistema respiratório: } \\
\text { - congestão nasal, asma, danos nos } \\
\text { pulmões e tosse } \\
\text { - irritação nos olhos } \\
\text { - dores de cabeça } \\
\text { - dores no peito }\end{array}$ \\
\hline
\end{tabular}




\begin{tabular}{ccl}
\hline & Tráfego & Afeta sistema respiratório: \\
& Indústrial & - bronquites crônicas, crises respiratórias, \\
Partículas $\left(\mathrm{PM}_{10}\right.$ e $\left.\mathrm{PM}_{25}\right)$ & Construção & irritação das vias respiratórias \\
& civil & - crises cardíacas \\
& Agricultura & - redução da visibilidade \\
& Fogos florestais & - irritação das mucosas dos olhos \\
\hline
\end{tabular}

Fonte: adaptado de CCDRC (2009a e 2009b) e CCDRN (2011).

Tal como a utilização do automóvel, a sinistralidade rodoviária tem apresentado uma tendência crescente, tendo sido, em 2016, a oitava causa de morte em nível mundial (WHO, 2018a). Se, em alguns países com elevada taxa de motorização, a taxa de sinistralidade está a decrescer, noutros, a taxa de sinistralidade tem vindo a aumentar a par do aumento da taxa de motorização (Rodrigue et al., 2006; Black, 2010). Dessa sinistralidade, são os peões e os utilizadores de bicicleta os que se encontram mais expostos e vulneráveis pela sua reduzida capacidade de reação e resposta. Desse modo, para além dos comportamentos como condutor, os comportamentos seguros como peão ou ciclista devem fazer parte das competências sociais dos indivíduos para a minimização da sinistralidade (Morrongiello e Barton, 2009; Mcmillan, 2013; Leandro e Marques da Costa, 2013).

Figura 1 - Determinantes da saúde

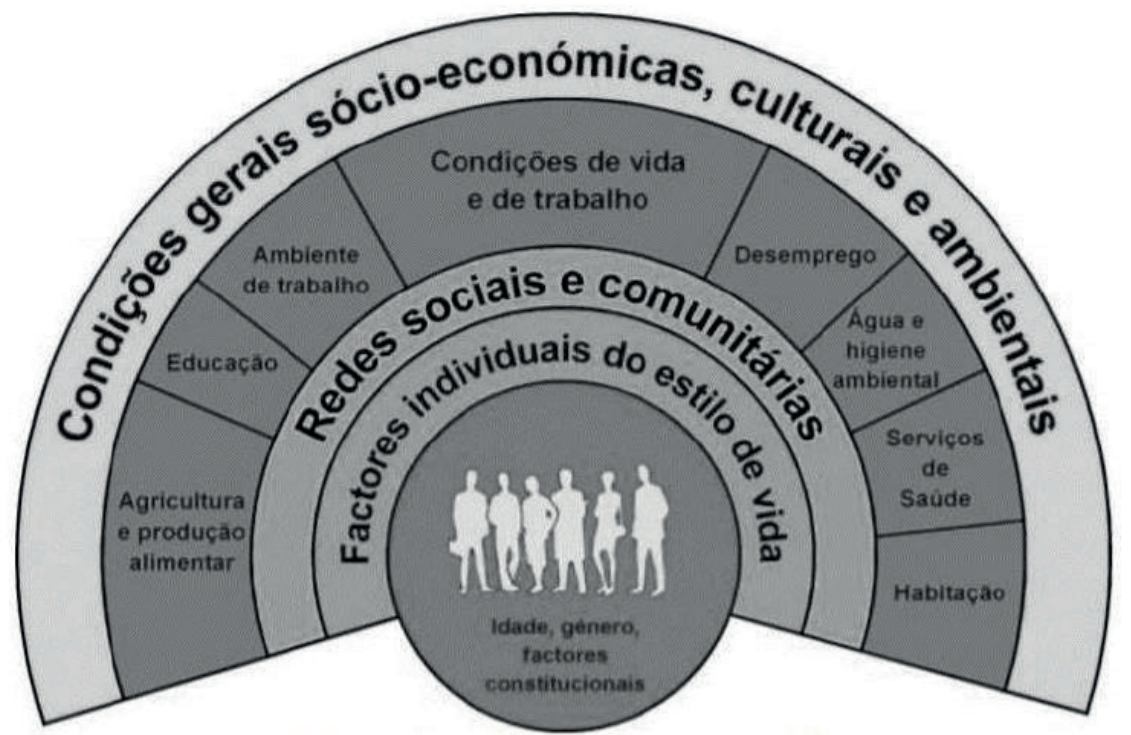

Fonte: Whitehead e Dahlgren, 1991, apud Miranda (2013, p. 6). 
A questão da saúde da população em áreas urbanas não é uma preocupação recente, tendo sido associado ao papel dos determinantes sociais na saúde (Vlahov et al., 2004; Williams, 2013; Marques da Costa, 2013; Louro et al., 2019). Os determinantes da saúde têm sido analisados, ao longo das últimas décadas, ancorados no esquema proposto por Whitehead e Dahlgren (1991) (figura 1), que considera não apenas os fatores do indivíduo e do seu estilo de vida, mas também as características das suas redes sociais e da inserção comunitária, bem como as suas condiçôes socioeconômicas, culturais e ambientais.

Em 2010, a OMS-Europa apresentou um modelo conceitual para a saúde urbana, no qual se sugere que a promoção da saúde é beneficiada não apenas pelas melhorias nos serviços de saúde, mas também com intervenções no âmbito dos diferentes determinantes nos ambientes físico, social e ambiental (Marques da Costa, 2013).

A OMS-Europa propôs igualmente um outro esquema dos deter-minantes da saúde e bem-estar nas cidades (figura 2), numa abordagem que conjuga vários níveis, do individual ao ecossistema global. Em todos os níveis, podemos identificar ligaçóes diretas e indiretas do transporte na saúde. No nível individual, surge o efeito da sinistralidade, enquanto a importância do transporte ativo no combate ao sedentarismo e na preven-ção de doenças cardíacas, diabetes e depressão, entre outras, é associada aos estilos de vida.

No nível da comunidade, é sublinhada a importância do transporte para a coesão social e o reforço da rede social de apoio. O fácil acesso a habitação de qualidade, a equipamentos coletivos de saúde, educação, cultura e lazer e, ainda, ao comércio é destacado no contexto da economia local, onde o transporte detém um papel fundamental. $\mathrm{O}$ transporte é ainda importante no acesso ao emprego, permitindo o alargamento ou a redução da área de procura para cada indíviduo, de acordo com a sua capacidade de transpor a distância entre o local de residência e a do trabalho, e recorrendo aos diferentes modos de transporte. 
Figura 2 - Determinantes da saúde revisitados

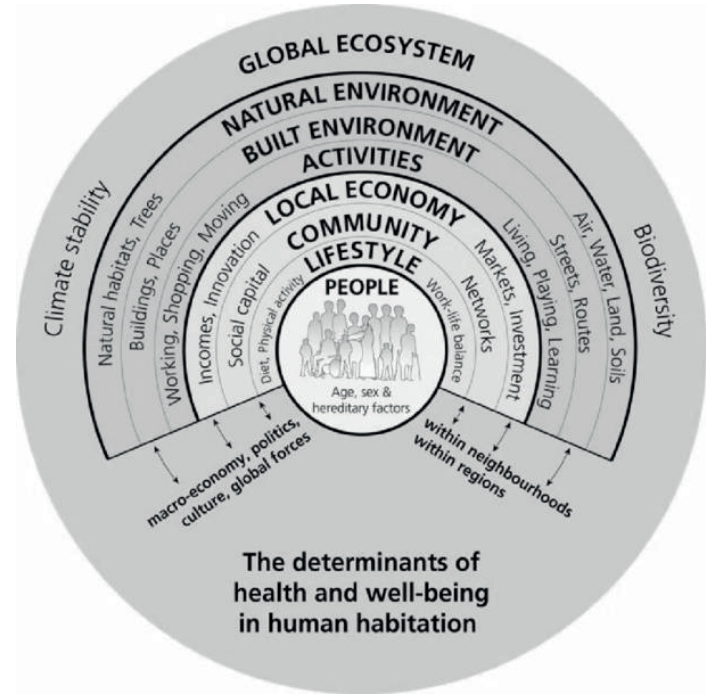

Fonte: WHO-Europe, 2010, p. 29.

No nível do ecossistema global, o transporte tem sido considerado como um dos principais promotores de poluição atmosférica, nomeadamente de emissôes de $\mathrm{CO}_{2}$ e de outros poluentes, com impacto negativo no aquecimento global e, consequentemente, na saúde da população (ex.: asma, doenças cardíacas e pulmonares).

Nesse sentido, tais determinantes relacionam-se intimamente com o planeamento urbano, considerando a conjugação dos condicionantes de natureza global, regional e local nos domínios dos ambientes físico e social e do acesso aos serviços (Marques da Costa, 2017).

Essa perspetiva, centrada nos determinantes de saúde, alicerçou a noção de cidade saudável, recentrando a abordagem da saúde ligada ao indivíduo numa abordagem da saúde ligada à comunidade urbana e sustentada na melhoria dos diferentes fatores que determinam a saúde das populaçóes. Assim, não é possível dissociar o transporte com o planeamento das intervençôes relacionadas com a saúde e com a concretização da cidade saudável.

Segundo Hancock e Duhl (1988), a cidade saudável é “aquela que está continuamente a criar e desenvolver os seus ambientes físico e social, e a expandir os recursos comunitários que permitem às pessoas apoiarem-se mutuamente nas várias dimensóes da sua vida e no desenvolvimento do seu 
potencial máximo” (Glouberman et al., 2006, p. 327). Nessa perspetiva, não se pretendia apenas atingir uma meta, mas também implementar uma estratégia de curto e longo prazo, em que a saúde seria integrada em todas as políticas (Lawrence, 2005).

O Movimento Cidades Saudáveis surge em 1987, liderado pela OMS, com a realização do debate "Saúde para Todos no Século XXI", a que se sucede o lançamento do Projeto Cidades Saudáveis (PCS), globalmente reconhecido pela promoção da saúde e dos seus determinantes em todas as políticas (OMS, 1997).

Os PCS são desenvolvidos no seio da Rede Europeia de Cidades Saudáveis (RECS) e de outras redes regionais da OMS, bem como pelas Redes Nacionais de Cidades Saudáveis. A RECS reúne cerca de 1.400 cidades de 30 países diferentes e promove a saúde nas agendas social, econômica e política dos governos locais, baseada na equidade, governança participativa e solidária, colaboração intersetorial e ação sobre os determinantes de saúde (WHO-Europe, s.d. a).

Em Portugal, foi em 1997 que se formalizou a associação de municípios que constituiu a Rede Portuguesa de Cidades Saudáveis, denominação que viria a ser alterada para Rede Portuguesa de Municípios Saudáveis (RPMS), dada a membresia ser exclusiva a autarquias municipais, refletindo o cariz municipal de atuação dos PCS. A RPMS tem como objetivos: "apoiar e promover a definição de estratégias locais suscetíveis de favorecer a obtenção de ganhos em saúde" e "promover e intensificar a cooperação e a comunicação entre os municípios que integram a Rede e entre as restantes redes nacionais participantes no PCS da OMS” (RPMS, s.d.).

\section{Breve olhar sobre as realidades de Portugal Continental}

Como referido anteriormente, três grandes problemas - motorização, sinistralidade rodoviária e poluição atmosférica - destacam-se na discussão do papel do transporte para o desenvolvimento de territórios saudáveis (Louro e Marques da Costa, 2017). Importa então olhar para a realidade nacional recente, considerando algumas tendências em nível municipal.

Acompanhando a evolução geral, o aumento da motorização dos portugueses foi bastante significativo, tendo passado dos 455 veículos ligeiros por 1.000 habitantes em 2008, para 579 em 2017, e aumentado na maioria dos municípios do Continente, com exceção dos municípios de: Monchique, na 
regiāo do Algarve; do Barreiro, na Área Metropolitana de Lisboa; de Ansião e Sernancelhe, da regiáo Centro; e de Lousada, Porto e Mesão Frio, na região Norte (mapa 1).

Mapa 1 - Taxa de motorização municipal em Portugal Continental (2008 e 2017) (n. ${ }^{\circ}$ de viaturas por 1.000 habitantes)
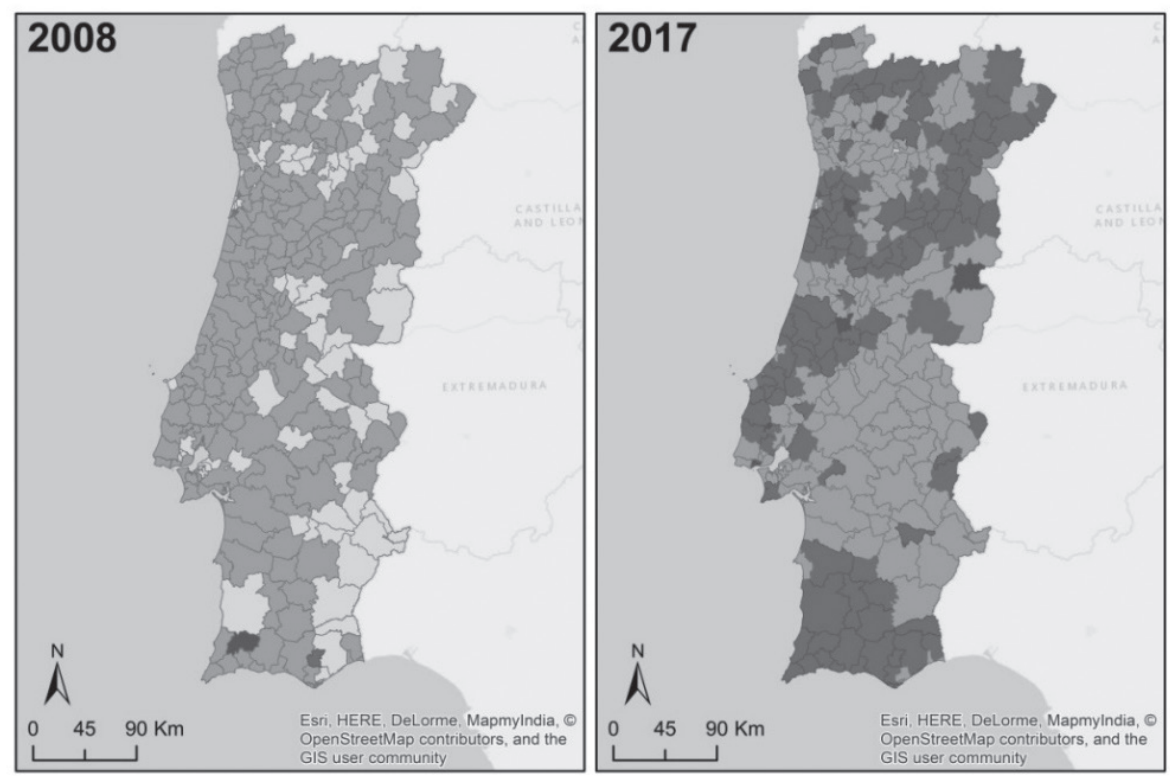

Taxa de Motorização (\%)

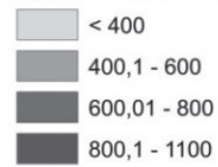

Fonte: Parque Automóvel Seguro. Cálculo e elaboração própria.

Concomitantemente, verificou-se o aumento da utilização do automóvel para as deslocaçóes quotidianas, passando de $46 \%$ das deslocaçóes pendulares no Continente em 2001, para 62\% em 2011. O padrão territorial da utilização do automóvel não se alterou siginificativamente, tendo-se antes registado um aumento generalizado da sua utilização em todos os municípios (mapa 2).

A utilização do automóvel permitiu o aumento da amplitude das deslocaçôes, pela velocidade e a maior autonomia de escolha por parte dos indivíduos, o que provocou uma alteração das bacias de emprego, alargando-as 
e gerando uma relação entre origens e destinos mais diversa e complexa e dificultando a resposta por parte do transporte público (Louro e Marques da Costa, 2016).

A transferência modal a favor do automóvel deu-se essencialmente à diminuição da utilização de modos suaves (a pé ou de bicicleta), de 28\% para $18 \%$ entre 2001 e 2011, e pela reduçáo da utilização do transporte público, que passou dos 25\% para os 20\%, no mesmo período. Apesar do decréscimo generalizado, a região de Lisboa destaca-se pela maior utilização desses modos (35\% em 2001 e 30\% em 2011), contrapondo com regióes onde essa opção é consideravelmente menor (10\% no Algarve, 12\% no Alentejo e 13\% no Centro, em 2011).

Mapa 2 - Taxa de utilização do automóvel em deslocações pendulares (2001 e 2011) (\%)
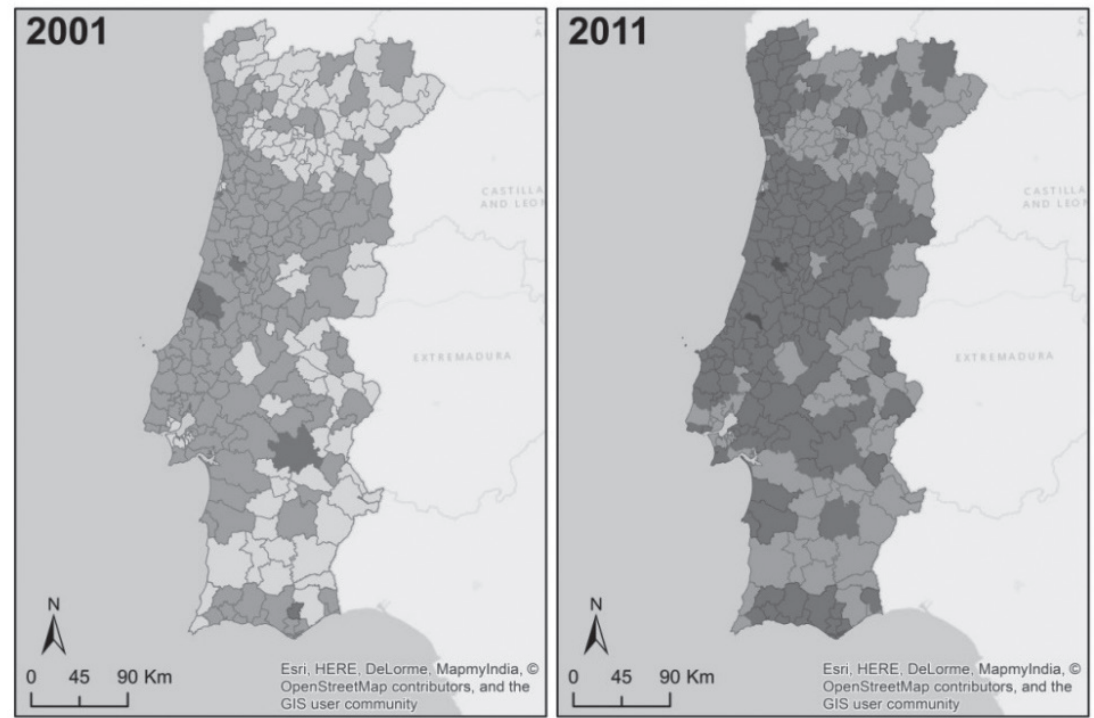

\% utilização de automóvel em deslocações pendulares

(2001 - 2011)

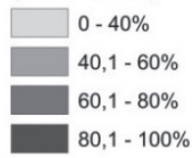

Fonte: INE. Cálculo e elaboração própria. 
Relativamente à sinistralidade rodoviária, verificou-se em Portugal um ligeiro decréscimo, de 32.732 acidentes de viação com vítimas por ano entre 2009 e 2013, para 32.318 entre 2014 e 2017. O mesmo se verifica para o número total de vítimas de acidentes de viação, que passaram de 43.103 por ano entre 2009-2013, para 41.841 no período 2014-2017, redução especialmente significativa em relação ao número de mortos, que diminuiu de 663 por ano entre 2009-2013, para 478 no período 2014-2017.

Mapa 3 - Número médio de vítimas de acidentes de viação por ano (20092013 e 2014-2017)
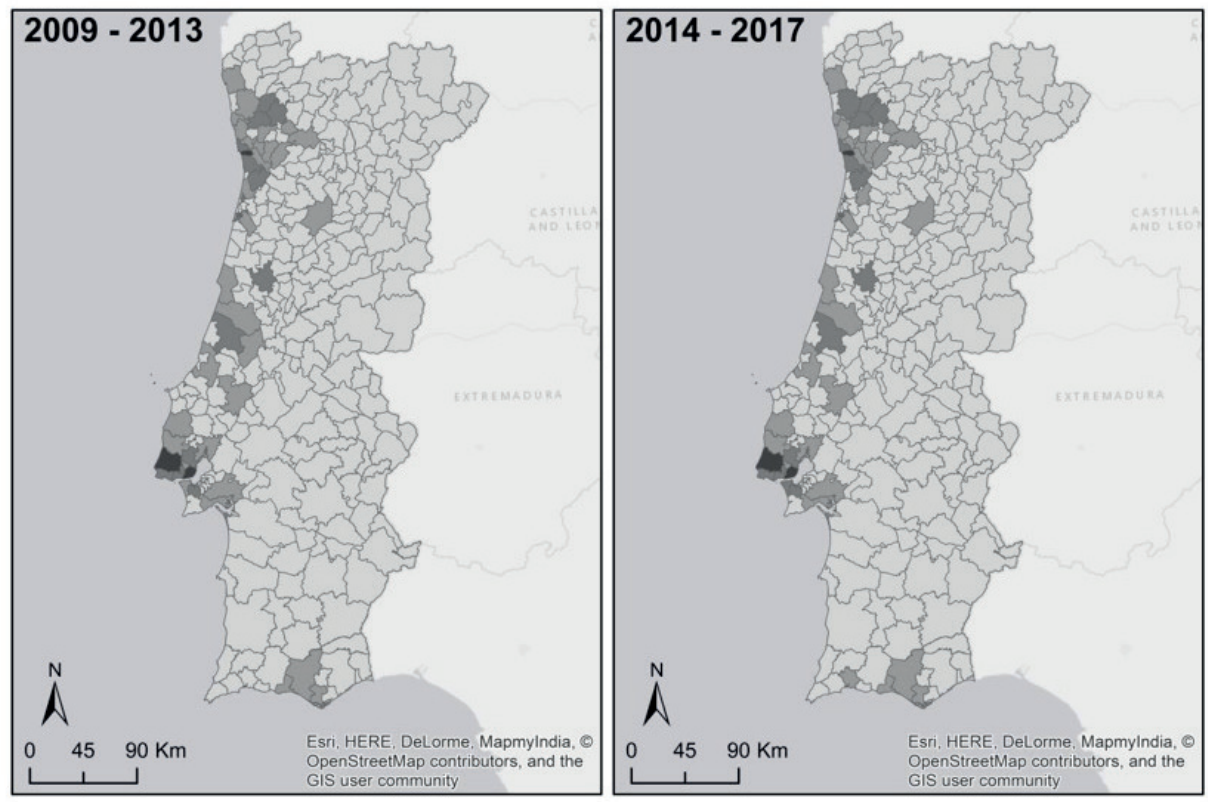

Número médio de vítimas de acidentes de viação por ano

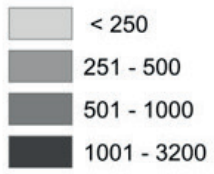

Fonte: INE. Cálculo e elaboração própria.

No nível municipal (mapa 3), o maior número médio de vítimas de acidentes de viação por ano nos munípios do litoral, seguindo a maior concentração populacional e o padrão do sistema urbano nacional. 
O terceiro aspecto a considerar no contexto da realidade portuguesa prende-se com a poluição atmosférica, na qual o transporte surge como uma das principais fontes. Embora não esteja disponível uma rede de recolha de informação sistemática muito densa, é possível dispor de informação relativa aos poluentes diretamente associados ao transporte, nomeadamente, monóxido de carbono $(\mathrm{CO})$, dióxido de azoto $\left(\mathrm{NO}_{2}\right)$, ozônio $\left(\mathrm{O}_{3}\right)$, e outras partículas inaláveis com diâmetro inferior a 10 micrômetros $\left(\mathrm{PM}_{10}\right)$. Considerando as regióes de medição da qualidade do ar (QualAr) da Agência Portuguesa do Ambiente (APA), verificou-se que, relativamente ao monóxido de carbono (CO), os níveis resgistados revelaram qualidade elevada do ar relativamente a esse poluente. Relativamente à medição do dióxido de azoto $\left(\mathrm{NO}_{2}\right)$, embora se tenham registado valores elevados de qualidade do ar associado a esse poluente na maioria das regiôes do país, verificaram-se em Braga, Porto e Lisboa os níveis de qualidade mais baixos, correspondendo a áreas de maior densidade populacional e de maior volume de tráfego rodoviário. Relativamente às mediçóes de partículas inaláveis, tanto as relativas às $\mathrm{PM}_{10}$ como $\mathrm{PM}_{25}$, registaram-se valores igualmente bons de qualidade do ar relativamente a esses elementos. No entanto, as mediçóes de Ozônio $\left(\mathrm{O}_{3}\right)$ revelam uma tendência negativa, tendo-se vindo a registar o aumento do número de dias em que os valores não atingem os máximos de qualidade do ar em relação a esse poluente.

\section{Instrumentos de política nacional para o transporte e mobilidade urbana}

Os três problemas anteriormente referidos - motorização excessiva, sinistralidade rodoviária e poluição atmosférica proveniente do transporte -, têm sido uma preocupação expressa em diferentes instrumentos de política nacionais, de cariz territorial e setorial. Neste capítulo, teremos em consideração:

1. documento de política territorial - Programa Nacional da Política de Ordenamento do Território - Revisão 2018 (PNPOT, DGT, 2018) ${ }^{1}$;

\footnotetext{
"Instrumento de topo do sistema de gestão territorial, define objetivos e opções estratégicas de desenvolvimento territorial e estabelece o modelo de organização do território nacional". Disponível em: http://pnpot.dgterritorio.pt/pnpot e https://www.parlamento.pt/ActividadeParlamentar/Paginas/DetalheIniciativa.aspx?BID=42949.
} 
2. documentos de política de transporte - Plano Estratégico de Transportes 2008-2020 (PET 2008-2020) e Diretrizes Nacionais para a Mobilidade do Pacote de Mobilidade (DNM-PM);

3. documentos de política em saúde - Plano Nacional de Saúde - Revisão e Extensão a 2020 (PNS 2020) e Programas de Saúde Prioritários (PSP 2020). Uma síntese da interpretação dos mesmos encontra-se na tabela 1 .

Tabela 1 - Transposição dos problemas relacionados ao transporte para os objetivos e medidas presentes nos instrumentos de política pública

\begin{tabular}{|c|c|c|c|c|c|c|}
\hline \multirow{2}{*}{ Instrumentos } & \multicolumn{2}{|c|}{ Motorização excessiva } & \multicolumn{2}{|c|}{$\begin{array}{l}\text { Sinistralidade } \\
\text { rodoviária }\end{array}$} & \multicolumn{2}{|c|}{$\begin{array}{l}\text { Poluiçáo atmosférica } \\
\text { oriunda do transporte }\end{array}$} \\
\hline & $\begin{array}{c}\text { Diagnós- } \\
\text { tico }\end{array}$ & $\begin{array}{c}\text { Inter- } \\
\text { vençáo }\end{array}$ & $\begin{array}{c}\text { Diagnós- } \\
\text { tico }\end{array}$ & $\begin{array}{c}\text { Inter- } \\
\text { vençáo }\end{array}$ & $\begin{array}{c}\text { Diagnós- } \\
\text { tico }\end{array}$ & $\begin{array}{c}\text { Inter- } \\
\text { vençáo }\end{array}$ \\
\hline \multicolumn{7}{|c|}{ 1) Instrumento de política territorial } \\
\hline PNPOT & $* * *$ & $* * *$ & * & $*$ & $* * *$ & $* * *$ \\
\hline \multicolumn{7}{|c|}{ 2) Instrumentos de política de transporte } \\
\hline $\begin{array}{c}\text { PET 2008- } \\
2020 \\
\end{array}$ & * & $* * *$ & $* * *$ & ** & $* * *$ & * \\
\hline DNM-PM & - & $* * *$ & - & * & - & $*$ \\
\hline \multicolumn{7}{|c|}{ 3) Instrumentos de política de saúde } \\
\hline PNS 2020 & - & - & - & - & - & - \\
\hline PSP 2020 & - & * & - & * & - & $*$ \\
\hline
\end{tabular}

Legenda: ${ }^{*}$ presença reduzida; ${ }^{* *}$ presença considerável; ${ }^{* * *}$ presença forte Fonte: Elaboração própria.

No PNPOT, os três problemas de transporte e mobilidade anteriormente identificados são considerados, especialmente no desafio territorial "4.2. Reforçar e integrar redes de acessibilidades e de mobilidade”, onde se assume que, após um período centrado na construção de novas infraestruturas rodoviárias, os desafios devem ser: por um lado, a manutenção e a conservação da rede, tendo em vista a redução da sinistralidade rodoviária; por outro, a promoção da descarbonização dos transportes por via dos veículos elétricos e a promoção da partilha de veículos, orientaçóes que terão impacto na redução do congestionamento e na diminuição da utilização de automóvel. A excessiva motorização é ainda referenciada como uma limitação à evolução para um padrão de mobilidade mais sustentável, com 
custos negativos nos níveis ambiental e de saúde, por via da excessiva emissão de poluentes e sinistralidade rodoviária (DGT, 2018).

Do ponto de vista das soluçóes, o PNPOT (DGT, 2018) responde aos problemas em estudo, especialmente em duas medidas: “4.4. Renovar, requalificar e adaptar as infraestruturas e os sistemas de transporte"; e "4.5. Promover a mobilidade metropolitana e interurbana”, surgindo como objetivos operacionais:

- reduzir externalidades negativas e aumentar a sustentabilidade ambiental por via da redução das emissões de poluentes atmosféricos e GEE;

- promover a descarbonização do setor de transporte;

- diminuir o descongestionamento por meio da melhoria da oferta e da qualidade do transporte público e da aposta nos modos mais sustentáveis;

- e viabilizar soluçóes para mobilidade mais eficiente, universal e inclusiva.

Tais medidas e objetivos operacionais têm em vista impactar na redução do congestionamento e suas externalidades, como as emissôes do sistema de transporte, no aumento da quota de mercado associada a modos mais sustentáveis, na diminuição da utilização do transporte individual motorizado e na redução das emissóes no setor de transporte.

No domínio da política de transporte, destacam-se três documentos. No primeiro, o Plano Estratégico de Transportes 2008-2020, a segurança rodoviária e as emissóes de GEE e gases poluentes provenientes do transporte e o seu impacto na saúde são identificados como problemas, enquanto a motorização excessiva surge como causa desses e de outros problemas. Por conseguinte, são apresentados quatro objetivos específicos e respectivos objetivos operacionais, bem como indicadores de resultado e de realização nos quais essas temáticas se enquadram ${ }^{2}$. A preocupação com a excessiva motorização repercute de forma muito evidente no amplo número de objetivos operacionais que promovem:

2 Objetivos:

- Objetivo Geral - Sistema de transportes que contribua para a coesão social e territorial, para uma economia nacional robusta e bem integrada a nível europeu e mundial, cómodo e seguro, respeitador do ambiente e eficiente do ponto de vista energético; 
- um melhor sistema de transporte público, seguro, acessível, com boa cobertura e adaptado à procura (objetivos 2.2, 3.1 e 3.2);

- a transferência modal do transporte individual para o transporte público, tendo em vista a redução do congestionamento (objetivo 3.3);

- e a promoção de modos suaves (objetivo 3.4), mensurado pela extensão das ciclovias e vias pedonais.

A sinistralidade rodoviária surge apenas como indicador, com a quantificação dos acidentes com peôes e ciclistas, num único objetivo operacional associado à segurança do transporte público (objetivo 3.2) e como indicador de impacto do objetivo geral do PET. Por fim, a única referência explícita à poluição atmosférica surge num indicador de impacto do objetivo geral do instrumento - diminuição das emissões de GEE e de poluentes pelo setor do transporte -, pese embora, referido como problema, a minimização do congestionamento vem beneficiar a redução das emissóes oriundas do transporte (objetivo 3.3).

No conjunto de Diretrizes Nacionais para a Mobilidade (Pacote da Mobilidade, 2012) $)^{3}$ são apresentadas onze linhas de orientação e os respectivos objetivos. Nesse contexto, a questão da motorização excessiva é central

- Objetivo Específico 2 - Melhor articulação entre os centros urbanos que compóem os diferentes níveis do sistema urbano nacional e entre cada centro e a restante área de influência;

- Objetivo Operacional 2.2 - Redes e serviços de transporte público em permanente adequação à dinâmica da procura e estruturados de forma a promover a cobertura supramunicipal e a utilização dos modos de transporte mais adequados às características das deslocaçôes;

- Objetivo Específico 3 - Mobilidade urbana mais compatível com uma elevada qualidade de vida;

- Objetivo Operacional 3.1 - Redes de Transporte Público urbano e suburbano em permanente adequaçáo à dinâmica da procura, assegurando boa cobertura territorial e a conectividade das periferias entre si e entre estas e os centros principais, maximizando as ligaçóes directas e potenciando a intermodalidade e as vocaçóes de cada modo;

- Objetivo Operacional 3.2 - Serviços de TP facilmente inteligíveis, acessíveis, seguros e cómodos para o cliente;

- Objetivo Operacional 3.3 - Repartição modal TI/TP mais equilibrada a favor do transporte público, sem congestionamentos de tráfego significativos;

- Objetivo Operacional 3.4 - Acentuado crescimento da utilizaçáo dos modos suaves na mobilidade urbana.

3 As Diretrizes Nacionais definem as principais Linhas de Orientação para a Política Nacional de Mobilidade e devem ser entendidas como instrumento que identifica e enquadra as várias figuras de planeamento da Mobilidade e Transportes (Pacote da Mobilidade, 20, p. 4). 
na medida em que surge na maioria das linhas de orientação, em diversas perspetivas:

- uma primeira prende-se com a abordagem ao transporte individual, onde se promove a contenção do volume global de viagens motorizadas, especialmente em transporte individual (linha de orientação D), e o aumento da taxa de ocupação dos veículos (linha de orientação F);

- uma segunda perspectiva relaciona-se com a promoção da transferência modal do transporte individual para modos mais sustentáveis (linha de orientaçãa F), onde se incluem o transporte coletivo e os modos suaves. A promoção do transporte público por meio de uma boa cobertura territorial, qualidade do serviço e eficiência econômica e ambiental é bastante evidente (linhas de orientação A, B, D, G), havendo ainda preocupaçóes voltadas para a utilização de modos suaves por meio da existência de boas condiçóes de serviço para peóes e ciclistas (linha de orientação E).

- a perspectiva relacionada aos temas da sinistralidade rodoviária e da poluição atmosférica nunca surgem de forma explícita, mas são enquadradas na linha de orientação "D. Melhorar a qualidade de vida dos cidadãos pela redução dos impactes negativos da mobilidade", que objetiva a evoluçáo da mobilidade urbana pelo uso de modos de transporte mais limpos e mais seguros e pela redução dos custos de externalidade geradas pelo congestionamento pela promoção da diversidade de soluçóes de mobilidade, e ainda nas linhas de orientação associadas ao transporte coletivo e aos modos suaves (linhas de orientação A, B, D, E, G).

Outros documentos à escala local, tais como os Planos de Mobilidade Urbana Sustentável, foram analisados noutros estudos à luz das premissas do movimento Cidades Saudáveis (Louro et al., 2019).

Há ainda a referir o quadro de instrumentos de planeamento da saúde. Este é um vasto conjunto de documentos (Marques da Costa, 2016), onde se incluem o Plano Nacional de Saúde 2020 e os Programas de Saúde Prioritários ${ }^{4}$.

4 Programas de Saúde Prioritários: a) Prevenção e Controlo do Tabagismo; b) Promoção da Alimentação Saudável; c) Promoção da Atividade Física; d) Diabetes; e) Doenças Cérebro-cardio- 
No caso do PNS 2020 (DGS, 2015), não se verifica qualquer referência direta às questóes em estudo. Contudo, destaca-se no eixo estratégico "Políticas saudáveis" um conjunto de propostas que podem, direta ou indiretamente, integrar o transporte e seus impactos para a Cidade Saudável, designadamente a promoção da "Saúde em Todas as Políticas" e de estratégias intersetoriais de minimização de alguns fatores de risco como o alcoolismo ou a promoçáo de modos suaves (andar a pé ou de bicicleta) para a realizaçáo de atividade física.

Quanto aos vários Programas de Saúde Prioritários, dos 12 existentes, apenas um, o Programa Nacional para a Promoção da Atividade Física (DGS, 2016), relaciona-se com este estudo, na medida em que promove a mobilidade por modos suaves, como prática de atividade física para um estilo de vida fisicamente ativo, como também sinal de saúde e bem-estar. Para tal, é sublinhada a importância da criação de ambientes urbanos seguros e de qualidade no nível das ciclovias e passeios, procurando evitar a sinistralidade rodoviária e considerando os peões e ciclistas como os elementos mais sensíveis, destacando-se ainda que a promoção dos modos suaves minimizaria a quota de deslocaçóes motorizadas e emissóes poluentes associadas.

\section{Intervenções no transporte e mobilidade urbana para a Cidade Saudável}

A RPMS reúne atualmente 59 municípios em Portugal, representando, no seu conjunto, $19 \%$ da superfície do território nacional e $40 \%$ da população residente (RPCS, s.d.).

A atuação dos PCS, embora vocacionada para os níveis local e municipal, integra as orientaçóes provenientes da OMS e da RPMS, da legislação e diretivas nacionais, e das políticas públicas nacionais e regionais. No nível de cada município, dependem ainda da estrutura orgânica e de competências das autarquias locais, dos recursos humanos e técnicos disponíveis e, ainda, das características do território e da comunidade servida (Louro et al., 2018).

No contexto dos PCS, identifica-se um conjunto de áreas de intervenção mais frequentes - "Equidade no acesso à Saúde”, "Ação/Inclusão Social”, "Literacia e Educação para a Saúde", "Edificado e Espaço Público" e "Mobilidade

\footnotetext{
vasculares; f) Doenças Oncológicas; g) Doenças Respiratórias; h) Hepatites Virais; i) Infecção VIH/SIDA; j) Prevenção e Controlo de Infecçôes e de Resistência aos Antimicrobianos; k) Saúde Mental; e l) Tuberculose. Disponível em: https://www.sns.gov.pt/institucional/programas-de-saude-prioritarios/.
} 
Urbana”, bem como se sublinha a diversidade de grupos-alvo a que se destinam as intervenções, desde grupos dependentes, como as crianças, jovens e idosos, grupos sensíveis, como população social e economicamente carenciada, ou a comunidade em geral (Louro et al., 2017) (figura 3).

Figura 3 - Perspetivas de intrevenção, áreas de intervenção e grupos-alvo dos PCS

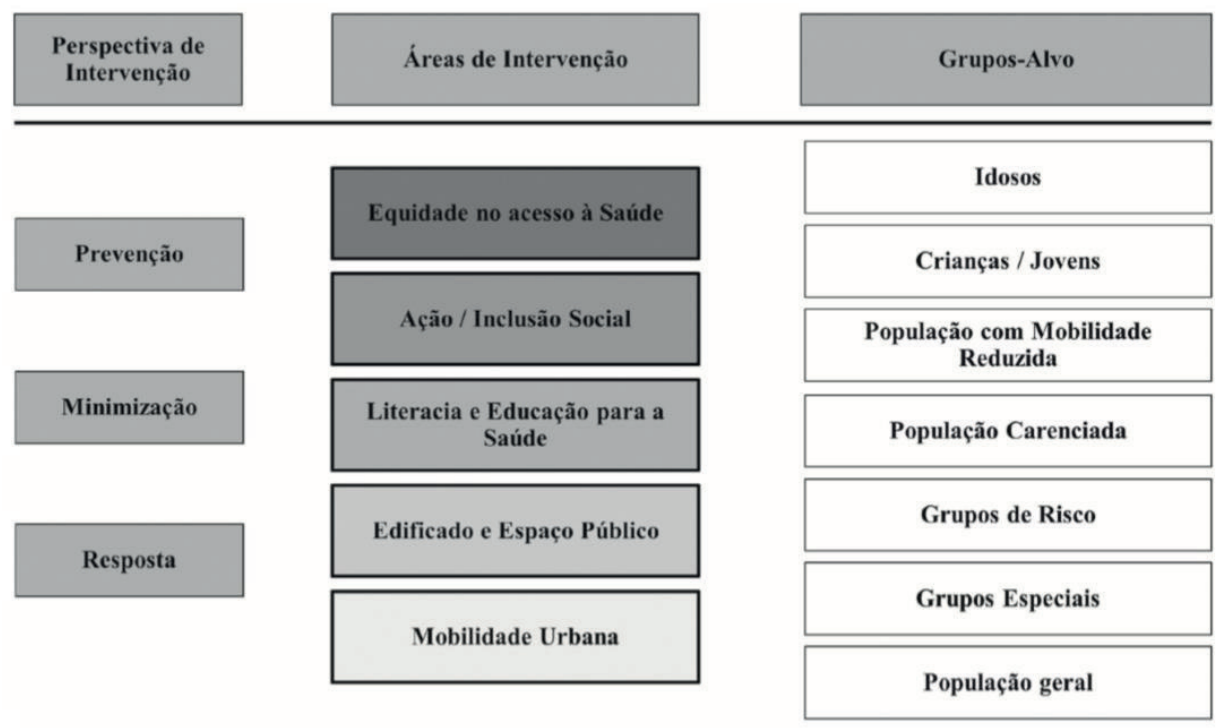

Fonte: Louro et al., 2017, p. 52.

Considerando a listagem de projetos dos municípios membros da RPMS, à data de agosto de 2019, são relativamente escassos aqueles que diretamente se relacionam com o transporte e a mobilidade urbana (33 projetos, num total de 544) (tabela 2). Embora em número diminuto, os projetos distinguem-se em três eixos distintos: 1) projetos diretamente associados ao transporte e à mobilidade urbana; 2) projetos de promoção de modos de deslocação suaves (a pé ou de bicicleta); e 3) projetos de cariz social associados ao transporte e à mobilidade. 
Tabela 2 - Listagem dos projetos na área do transporte dos PCS

\begin{tabular}{|c|c|}
\hline Município & Denominação dos projetos \\
\hline Alfândega da Fé & $\begin{array}{l}\text { Percursos Pedestres (lazer e atividade física) } \\
\text { Unidade Móvel de Saúde } \\
\text { Unidade Domiciliária de Cuidados Paliativos de A. Fé }\end{array}$ \\
\hline Amadora & $\begin{array}{l}\text { Amadora Bikes (lazer e competição) } \\
\text { Amadora Caminha (lazer e atividade física) }\end{array}$ \\
\hline Barreiro & TCBike (rede de bicicletas elétricas) \\
\hline Bragança & Percursos Pedestres Rurais (lazer e atividade física) \\
\hline Castro Marim & Unidade Móvel de Saúde \\
\hline Coimbra & $\begin{array}{l}\text { Renovação da frota dos SMTUC através de Autocarros Elétricos } \\
\text { Ciclovia de Coimbra }\end{array}$ \\
\hline Figueira da Foz & Serviço de Transporte Municipal \\
\hline Lisboa & A Segurança Começa em Ti \\
\hline Lousã & Lousã a Pedalar \\
\hline Miranda do Corvo & Unidade Móvel de Apoio ao Cidadão \\
\hline Monção & Rede de Percursos Pedestres \\
\hline Odemira & Caminhadas \\
\hline Oeiras & Programa Oeiras Município Acessível \\
\hline Palmela & Loja Móvel do Cidadão \\
\hline Seixal & $\begin{array}{l}\text { Projeto Municipal de Segurança Rodoviária } \\
\text { Saúde sobre Rodas }\end{array}$ \\
\hline Serpa & $\begin{array}{l}\text { Semana Europeia da Mobilidade } \\
\text { Projetos de implementação de ciclovias }\end{array}$ \\
\hline Torres Vedras & Porta a Porta \\
\hline Viana do Castelo & $\begin{array}{l}\text { ABC da Caminhada } \\
\text { Pegada Saudável }\end{array}$ \\
\hline Vila Real & Unidade Móvel de Saúde \\
\hline
\end{tabular}

Fonte: RPMS, s.d. a. Elaboração própria.

No primeiro eixo identificam-se os projetos diretamente associados ao transporte e à mobilidade urbana, apresentando alguma diversidade de tipologias. Os projetos "TCBike" no Barreiro, "Ciclovia de Coimbra" e "Ciclovias em Serpa” estão ancorados à promoção da utilização da bicicleta por meio da criação de infraestruturas e existência de sistemas de veículos partilhados associados ao sistema de transporte público. Relativamente ao transporte público municipal, destaca-se o projeto "Renovação da frota dos SMTUC (Serviços 
Municipalizados de Transportes Ubanos de Coimbra) através de Autocarros Elétricos”, em Coimbra. Relativamente à segurança rodoviária, destaca-se o "Projeto Municipal de Segurança Rodoviária", no Seixal, ao qual se associa o projeto “A Segurança Começa em Ti”, em Lisboa, que sensibiliza para a importância de comportamentos seguros na condução, nomeadamente a influência do consumo excessivo de álcool. Finalmente, em Serpa, sublinha-se a participaçáo na "Semana Europeia da Mobilidade" como forma de sensibilizaçáo para a mobilidade sustentável por parte de toda a comunidade (participação verificada aual por vários municípios portugueses).

Tabela 3 - Projetos associados ao transporte e à mobilidade urbana desenvolvidos em municípios saudáveis

\section{TCBike (Barreiro)}

O QUE É? Integração de uma rede de bicicletas elétricas, inicialmente $10 \mathrm{em}$ duas estaçóes de recolha/entrega, na rede de transportes públicos do município.

O QUE FAZ? Permite aos utilizadores de transporte público aceder à utilização da rede de bicicletas elétricas dos TCB, com recurso ao seu título de transporte. Permite deslocaçóes impossíveis de realizar em veículos pesados, como o casco antigo do Barreiro, com recurso a soluçóes suaves de mobilidade e integradas na lógica de disponibilização de transporte público do município.

A QUEM SE DESTINA? A todos os cidadãos.

QUAIS AS PARCERIAS? Câmara Municipal do Barreiro e fornecedores de serviço, designadamente a Bewegen, a $3 \mathrm{~W}$ e a Clever Way Mobile international.

Fonte: RPMS, s.d. b.

\section{Renovação da frota dos SMTUC através de Autocarros Elétricos (Coimbra)}

O QUE É? Renovação da frota de autocarros dos Serviços Municipalizados de Transportes Urbanos de Coimbra (SMTUC) com veículos mais eficientes e que utilizem fontes de energia com melhor desempenho ambiental. [...] Há ainda o compromisso dos SMTUC de abaterem um autocarro em fim de vida por cada autocarro elétrico recebido. A Câmara Municipal de Coimbra tem conseguido comparticipaçáo europeia na aquisição dos veículos elétricos, através da candidatura ao Programa Operacional Sustentabilidade e Eficiência no Uso de Recursos (POSEUR) para a "Promoção da eficiência energética nos transportes coletivos de passageiros incumbidos de missóes de serviços público". 
O QUE FAZ? Reduz-se o impacte negativo das emissões de gases com efeitos de estufa e de outros poluentes atmosféricos. Através da renovação da frota dos SMTUC, recorrendo a veículos com melhor desempenho ambiental, teremos uma cidade mais saudável, com menos gases e menos poluição atmosférica.

A QUEM SE DESTINA? A todos os cidadãos do concelho.

QUE RESULTADOS FORAM ATINGIDOS? Melhoria da qualidade do ar e do ambiente urbano. Com a aquisição de 10 veículos elétricos (oito autocarros e dois miniautocarros) para os SMTUC, foram abatidos 10 autocarros em fim de vida e conseguiu-se reduzir a emissão de gases com efeitos de estufa produzidos pelos transportes públicos municipais. O objetivo é prosseguir com esta aposta na aquisição de veículos com melhor desempenho ambiental, tendo já a autarquia avançado com outra candidatura ao POSEUR para reforçar a frota dos SMTUC com mais 14 novos autocarros elétricos. O estudo de viabilidade financeira realizado demonstrou a sustentabilidade do projeto, realçando-se o facto dos autocarros elétricos permitirem uma redução de $68 \%$ nos custos energéticos, relativamente aos Diesel convencionais que serão substituídos.

QUAIS AS PARCERIAS? Câmara Municipal de Coimbra e Serviços Municipalizados de Transportes Urbanos de Coimbra.

Fonte: RPMS, s.d. c.

\section{A Segurança Começa em Ti (Lisboa)}

O QUE É? Açôes de Formação e Sensibilização para a temática Álcool e Condução.

O QUE FAZ? Formação - sessóes destinadas a adquirir conhecimentos sobre os principais efeitos do álcool; Sensibilização - consciencialização e responsabilização dos jovens para a adoção de comportamentos seguros enquanto utilizadores da via pública. Trabalhos práticos realizados com os alunos: - Exposiçóes de trabalhos; - Campanhas no âmbito da disciplina de Formação Cívica/Educação para a Cidadania [...].

A QUEM SE DESTINA? Aos alunos do 8. ${ }^{\circ}$ e $90^{\circ}$ ano do ensino básico.

QUAIS AS PARCERIAS? Câmara Municipal de Lisboa, PSP Escola Segura.

Fonte: RPMS, s.d. d. 
No segundo eixo, surgem os projetos de promoção de modos de deslocação suaves. Alguns exemplos promovem a deslocação pedonal, como acontece nos projetos "Percursos Pedestres" em Alfândega da Fé, "Amadora Caminha" na Amadora, "Percursos Pedestres Rurais" em Bragança, "Rede de Percursos Pedestres" em Monção, "Caminhadas" em Odemira e, finalmente, "ABC da Caminhada" e "Pegada Saudável” em Viana do Castelo, enquanto outros promovem a utilização da bicicleta, como nos projetos "Amadora Bikes" na Amadora e "Lousã a Pedalar" na Lousã. Pese embora a maioria desses projetos apresente uma natureza lúdica, estes servem para promover os modos suaves como atividade física aliada ao lazer e competição e, de forma menos explícita, à sensibilização da sua possível utilização para a realização de deslocaçóes quotidianas.

Tabela 4 - Projetos de promoção de modos de deslocação suaves desenvolvidos em municípios saudáveis

\section{Projeto Pegada Saudável (Viana do Castelo)}

O QUE É? [...] foi criado em 2008, com o principal objetivo de introduzir a prática regular de atividade física no quotidiano da população, incentivando-a a caminhar e, ao mesmo tempo, potenciar a vivência dos espaços pedonais da cidade.

O QUE FAZ? Consiste em seis percursos urbanos [...], sinalizados com um pé marcado no chão, pintado com 6 cores diferentes (amarelo, verde, azul, rosa, laranja e branco) [...]. Estão sinalizados com a sinalética homologada para os Percursos Pedestres, com identificação de Percurso Local, o grau de dificuldade, a distância e acessibilidade. Os percursos são utilizados livremente pela comunidade ou em caminhadas organizadas pelo Gabinete Cidade Saudável. [...] grupos organizados, em caminhadas solidárias [...], escolas, Escuteiros e associaçóes desportivas e de lazer.

A QUEM SE DESTINA? População em geral.

QUAIS AS PARCERIAS? Escola Superior de Desporto e Lazer e Escola Superior de Saúde do Instituto Politécnico de Viana do Castelo e Associaçóes Desportivas.

Fonte: RPMS, s.d. e.

Por fim, o terceiro eixo diz respeito a projetos de cariz social associados ao transporte e à mobilidade, em grande parte na minimização de problemas ligados à exclusão ao acesso aos serviços de saúde por meio da deslocação de profissionais 
e equipamentos de saúde a áreas e comunidades mais sensíveis. Assinalam-se neste eixo vários projetos, tais como "Unidade Móvel de Saúde" em Alfândega da Fé, Castro Marim e Vila Real, "Unidade Domiciliária de Cuidados Paliativos de A. Fé" em Alfândega da Fé e "Saúde sobre Rodas" no Seixal. Numa perspetiva mais alargada, mas também promovendo a substituição das deslocaçôes dos utentes mais sensíveis, surgem os projetos "Unidade Móvel de Apoio ao Cidadáo" em Miranda do Corvo e "Loja Móvel do Cidadão" em Palmela. Finalmente, no "Programa Oeiras Município Acessível", é disponibilizado um Serviço de Transporte Adaptado para pessoas com mobilidade reduzida, assim como nos projetos "Serviço de Transporte Municipal” na Figueira da Foz, assegura-se o transporte para serviços de saúde por municípios em situação de carência e, no "Porta a Porta" em Torres Vedras, a deslocação aos vários equipamentos e serviços públicos por parte dos cidadãos com mobilidade condicionada.

Tabela 5 - Projetos de cariz social associados ao transporte e à mobilidade desenvolvidos em municípios saudáveis

\section{Saúde sobre Rodas (Seixal)}

O QUE É? O projeto Saúde sobre Rodas, iniciado em setembro de 2004, é um projeto de intervenção comunitária, através do qual é efetuada a prestação de cuidados de saúde primários e apoio social a populaçóes carenciadas do Município do Seixal.

O QUE FAZ? Este projeto é promovido por uma equipa multidisciplinar, composta por técnicos de saúde e da área social, que se desloca a bairros carenciados, utilizando para tal uma unidade móvel especialmente apetrechada para o efeito. Atua em diferentes áreas, nomeadamente no controle da saúde infantil e na vacinação, na prevenção da gravidez na adolescência e na articulação com os restantes cuidados de saúde primários.

A QUEM SE DESTINA? Crianças, jovens e mulheres (sobretudo em situações de risco), grávidas e puérperas constituem os grupos-alvo prioritários deste projeto. 
QUE RESULTADOS FORAM ATINGIDOS? Em termos gerais, os resultados positivos alcançados evidenciaram a importância desta resposta, tendo-se alargada a mesma a mais zonas do concelho. [...] verificou-se que este projeto gerou importantes ganhos, designadamente ao nível da saúde das pessoas (observável através da melhoria dos indicadores de saúde); nas dinâmicas sociais (através da criação de novas redes e da consolidação das já existentes); e na vertente interpessoal (através do desenvolvimento de competências pessoais e sociais determinantes em qualquer processo de promoção da saúde). [...] no ano de 2011, foram atendidos na unidade móvel de saúde 3.392 indivíduos, com especial incidência das camadas mais jovens da população. Entre os cuidados mais procurados pelos utentes, encontram-se as áreas do planeamento familiar e da saúde infanto-juvenil.

QUAIS AS PARCERIAS? Câmara Municipal do Seixal; Agrupamento de Centros de Saúde Seixal-Sesimbra/Unidade de Cuidados na Comunidade do Seixal; Hospital Garcia de Orta; Direção-Geral de Saúde.

Fonte: RPMS, s.d. f.

\section{Conclusão}

Este capítulo centrou-se na relação entre o transporte e a Cidade Saudável. Desta emergem três problemas especialmente concentrados em áreas urbanas motorização excessiva, sinistralidade rodoviária e poluição atmosférica causada pelo transporte. Assim, procurou-se compreender de que forma tais problemas são considerados nas realidades, políticas e intervenções dos Projetos Cidades Saudáveis em Portugal Continental. Quanto à realidade portuguesa, verificamos tendências contrárias no que respeita aos três problemas em estudo. Enquanto o crescimento da motorização é bastante evidente, já os fenômenos de sinistralidade rodoviária e de poluição atmosférica registam tendências favoráveis.

A partir da análise realizada, podemos sintetizar os três tópicos que orientam este capítulo - motorização excessiva, sinistralidade rodoviária e poluição atmosférica proveniente do transporte, segundo as três perspetivas abordadas - realidades, políticas e intervenções em Portugal (tabela 6). 
Tabela 6 - Síntese entre os problemas e as perspectivas estudadas (realidades, políticas e intervenções)

\begin{tabular}{lccc}
\hline & $\begin{array}{c}\text { Realidades em } \\
\text { Portugal }\end{array}$ & $\begin{array}{c}\text { Políticas de } \\
\text { transporte } \\
\text { saúde }\end{array}$ & $\begin{array}{c}\text { Intervenção } \\
\text { dos PCS }\end{array}$ \\
\hline Motorização excessiva & $* *$ & $* *$ & $* *$ \\
\hline Sinistralidade rodoviária & $* *$ & $*$ & $* *$ \\
\hline $\begin{array}{l}\text { Poluição atmosférica proveniente do } \\
\text { transporte }\end{array}$ & $* *$ & $*$ & $*$ \\
\hline
\end{tabular}

Legenda: * presença reduzida; ${ }^{* *}$ presença considerável; ${ }^{* * *}$ presença forte

Fonte: Elaboração própria.

Assim, na análise das realidades em Portugal, é possível observar a existência de alguns indicadores que refletem a evoluçáo dos problemas associados à relação entre os transporte e a saúde no nível municipal. A excessiva motorizaçáo torna-se muito evidente em Portugal pelo claro aumento da taxa de motorização, bem como do uso do automóvel para deslocaçóes pendulares. Pelo contrário, a sinistralidade rodoviária (acidentes rodoviários com feridos ou mortos) apresenta um decréscimo tanto em número absoluto como em termos relativos. Finalmente, acerca da avaliação do nível de qualidade do ar, esta tem apresentado tendências positivas quanto à maioria dos poluentes estudados $\left(\mathrm{CO}, \mathrm{NO}_{2}, \mathrm{PM}_{10}\right.$ e $\left.\mathrm{PM}_{25}\right)$, situação contrária à verificada na medição do ozônio $\left(\mathrm{O}_{3}\right)$.

Contudo, tal informação tem ainda algumas limitações. Por exemplo, a quantificação do fenômeno da motorização das deslocaçóes é relativamente limitada, pois apenas as deslocaçóes pendulares são passíveis de análise pela sua recolha sistemática pelos Censos, ficando toda a dinâmica complexa de deslocaçóes não pendulares por quantificar. Essa questão tem sido desenvolvida em alguns trabalhos para áreas mais restritas (Marques da Costa, 2007; Louro, 2019) e nos recentes inquéritos à mobilidade nas áreas metropolitanas de Lisboa e do Porto. Relativamente à sinistralidade rodoviária, apesar da existência de dados no nível municipal, esta omite as desigualdades entre áreas intramunicipais, sendo que a sua georreferenciação seria uma mais-valia para a análise (Braceiro, 2015; Sousa, 2017). Finalmente, a questão da poluição atmosférica é tida em grande consideração por um potente sistema de monitorização da Associação Portuguesa do Ambiente. Contudo, a distribuição das estaçôes de monitorização da qualidade do ar pelo país não é homogênea, obviamente 
concentrada em áreas mais sensíveis. Também a agregação de informação para a formação de indicadores no nível municipal ou por regiôes, como é o caso, esconde diferenças entre territórios e até entre situaçóes distintas durante o dia (ex.: momentos de congestionamento $v$ s momentos de pouca afluência).

No conjunto dos instrumentos de política analisados, onde se incluem instrumentos territoriais (PNPOT) e setoriais na área do transporte (PET 2008-2020 e DNM-PM) e da saúde (PNS 2020 e PSP 2020), observam-se situaçóes distintas. A primeira é a verificação de uma grande preocupação relativa à excessiva motorização, especialmente patente nas intervençóes propostas pelos instrumentos, enquanto as questóes da sinistralidade e da poluição atmosférica, embora frequentemente referenciadas nos diagnósticos associados aos instrumentos de política, estão pouco explícitas no conjunto das intervençôes sugeridas. Uma segunda situação a destacar é a evidente preocupação com os três problemas em estudo no PNPOT, instrumento de política territorial nacional e, obviamente, nos instrumentos de política de transporte, enquanto os mesmos surgem de forma muito diminuída nos instrumentos de política de saúde, mesmo sendo a relação transporte e saúde amplamente estudada e considerando que a Política Nacional de Saúde em Portugal promove a abordagem "Saúde em Todas as Políticas".

Por fim, no conjunto de intervençóes inseridas nos Projetos Cidades Saudáveis em Portugal, a proporção de projetos associados ao transporte é ainda reduzida. Na sua maioria, estes procuram, de várias formas, minimizar o fenômeno da motorização excessiva, promovendo, por exemplo, os modos suaves (a pé ou de bicicleta), inicialmente como atividade de lazer que pode eventualmente ser transposta no futuro como modo de deslocaçáo para as deslocaçôes diárias. Pouco abordada é a temática da sinistralidade, com um número escasso de projetos, enquanto a questão da poluição atmosférica é ainda menos referida. Todavia, é importante destacar que os municípios desenvolvem outras intervençóes em várias áreas do governo local que promovem a relação transporte e cidade saudável, nomeadamente nos departamentos associados ao transporte e ao planeamento urbano, bem como estáo patentes noutros instrumentos de política ou legislação nacional que integram essas preocupaçóes (Louro et al.; 2019; Louro, 2019).

Conclui-se, assim, haver certa coerência entre a leitura das realidades em Portugal quanto à relação transporte e Cidade Saudável, na medida em que o crescente fenômeno de excessiva motorização identificado estatisticamente é 
também a temática que demonstra ser a maior preocupação nos instrumentos de política territorial e de transporte, bem como nas intervençóes dos PCS. Por sua vez, e embora sejam ainda externalidades do transporte a ter em atenção, os fenômenos de sinistralidade rodoviária e de poluição atmosférica têm revelado melhorias, considerando a análise estatística da realidade portuguesa no nível municipal, estando menos evidentes nos instrumentos de política e nos PCS e beneficiando ainda todas as medidas de combate a um sistema de transporte ancorado no automóvel.

\section{Referências}

APA. "Ar e ruído: índice de qualidade do ar". s.d. Disponível em: https://rea.apambiente. pt/content/\%C3\%ADndice-de-qualidade-do-ar. Acesso em: 10 jun. 2019.

APP QUALAR. “Zonas de medição da qualidade do ar”. Cartografia. Disponível em: https://qualar.apambiente.pt/dashboard/observado/mapa/hoje. Acesso em: 3 maio 2019.

BANISTER, David. Unsustainable transport: city transport in the New Century. Londres: Routledge - Taylor \& Francis Group, 2005.

BLACK, William. R. Sustainable transportation: problems and solutions. Nova York: The Guilford Press, 2010.

BRACEIRO, Diana. Acumulação de acidentes rodoviários em Portugal Continental: contributo dos sistemas de informação geográfica (relatório de estágio de mestrado). UNL, 2015.

CCDRC. "Fontes e efeitos dos poluentes atmosféricos". 2009a. Disponível em: http:// www.ccdrc.pt/index.php?option $=$ com_content $\& v i e w=$ article\&id $=260$ : fontes-e-efeitos-dos-poluentes-atmosfericos\&catid=275\&Itemid=183. Acesso em: 2 ago. 2019.

. "Qualidade do ar”. 2009b. Disponível em: https://www.ccdr-n.pt/servicos/ ambiente/qualidade-ar. Acesso em: 2 ago. 2019.

CCDRN. "Relatório de Análise Estatística dos Dados de Qualidade do Ar, da Região Norte”. 2011. Disponível em: https://www.ccdr-n.pt/sites/default/files/ficheiros_ccdrn/ambiente/relatorio_qar_2011.pdf. Acesso em: 2 ago. 2019.

DGS. Plano Nacional de Saúde. Revisão e Extensão a 2020. Lisboa: DGS, 2015.

. Programa Nacional para a Promoção da Atividade Física. Lisboa: DGS, 2016.

DGT - PNPOT. Alteração: uma agenda para o território (Programa de Ação). Lisboa: DGT, 2018.

EU. Transport in figures. Luxemburgo: Publication Office of the European Union, 2018. GLOUBERMAN, Sholom et al. "A framework for improving health in cities: a discussion paper". Journal of Urban Health, Bulletin of the New York Academy of 
Medicine, v. 83, n. 2, p. 325-38, 2006. Disponível em: http://doi.org/10.1007/ s11524-006-9034-9.

HANCOCK, T. e DUHL, L. "Promoting health in the urban context". WHO Healthy Cities Papers, n., 1988.

HOLDEN, Erling. Achieving sustainable mobility: everyday and leisure-time travel in the EU. 10. ed. Hampshire: Ashgate, 2007.

IMTT. Directrizes Nacionais para a Mobilidade: Pacote de Mobilidade. Lisboa: IMTT, 2012.

INE. XIV Recenseamento Geral da População/IV Recenseamento Geral da Habitação. Lisboa: INE, 2001, Estatística.

.XV Recenseamento Geral da População/V Recenseamento Geral da Habitação. Lisboa: INE, 2011, Estatística.

LAWRENCE, Roderick J. "Building Healthy Cities: the World Health organization perspective”. In GALEA, Sandro e VLAHOV, David (eds.). Handbook of Urban Health: populations, methods, and practice. Nova York: Springer, 2005, p. 479-501.

LEANDRO, Hugo e MARQUES DA COSTA, Nuno. "Road Safety and Healthy Cities: the Seixal case study. CITTA 6th Annual Conference on Planning Research - Responsive Transports for Smart Mobility Road, at Coimbra, 2013.

LITMAN, Todd. "Sustainable Transportation Indicators: a Recommended Research Program for Developing Sustainable Transportation Indicators and Data". Transportation Research Board Annual Meeting, November 2008. Washington: TRB, 2008.

LOURO, Ana. Contributos da Gestão e Planeamento da Mobilidade Urbana para a construção de Cidades Saudáveis (tese). ULisboa, 2019.

e MARQUES DA COSTA, N. "Commuting flow patterns in LMA: towards an effective contribution to Sustainable Development. 12th International Symposium on Urban Planning and Environment. Lisboa: IGOT-ULisboa, 2016.

$\mathrm{e}$ "Indicadores de Transporte e Mobilidade Urbana para as Cidades Saudáveis: caso da Área Metropolitana de Lisboa, Portugal". GeoUERJ, v. 30, p. 99121, 2017. Disponível em: http://doi.org/10.12957/geouerj.2017.29735.

et al. "A Cidade Saudável no planeamento municipal: exemplos de atuação na AML, Portugal”. In RIBEIRO SOARES, Beatriz et al. (eds.). Construindo Cidades Saudáveis: utopias epráticas. Uberlândia: Assis Editora, 2017, v. II, p. 35-72.

et al. "Projetos Cidades Saudáveis na Área Metropolitana de Lisboa: exemplo da 'mobilidade urbana' como área de intervenção". Confins [online], v. 38, 2018. Disponível em: http://doi.org/10.4000/confins.16834.

et al. "Sustainable Urban Mobility Policies as a path to Healthy Cities: the case study of LMA, Portugal”. Sustainability, v. 31, n. 10, maio 2019Disponível em: http://doi.org/10.3390/su11102929.

MARQUES DA COSTA, Eduarda. "Cidades Saudáveis, saúde e sustentabilidade: dos conceitos às orientações de política na União Europeia”. In LIMA, Samuel do 
Carmo e MARQUES DA COSTA, Eduarda (eds.). Construindo Cidades Saudáveis. Uberlândia: Assis Editora, 2013, p. 45-64.

. “Da ação em saúde à ação para a saúde”. In OLIVEIRA, José A. e ALVES DE

SOUSA, Geraldo (eds.). Geografia da saúde: ambientes e sujeitos sociais no mundo globalizado. Manaus: EDUA, 2016, p. 71-94.

"Desconstruir utopias e construir novas práticas para um planejamento urbano saudável”. VI Simpósio Internacional Saúde Ambiental para Cidades Saudáveis. Uberlândia: UFU, 2017.

MARQUES DA COSTA, Nuno. Mobilidade e transporte em áreas urbanas: o caso da Area Metropolitana de Lisboa (tese). ULisboa, 2007.

MCMILLAN, T. Children and youth and Sustainable Urban Mobility. Nairobi: UNHABITAT, 2013.

MEE. Plano Estratégico dos Transportes e Infraestruturas 2014-2020. Lisboa: MEE, 2011. MELO DOS SANTOS, Sofia. Das pessoas e seus lugares: mobilidade quotidiana e desigualdades socioterritoriais na Lisboa metropolitana (tese). ISCTE-IUL, 2015.

MIRANDA, Natércia. "Investigação em promoção da saúde”. In MINISTÉRIO DA SAÚDE. Instituto Ricardo Jorge. Lisboa, 2013.

MOPTC. Plano Estratégico de Transportes 2008-2020. Lisboa: MOPTC, 2009.

MORRONGIELLO, Barbara e BARTON, Benjamin K. "Child pedestrian safety: parental supervision, modeling behaviors, and beliefs about child pedestrian competence". Accident; Analysis and Prevention, v. 4, n. 5, p. 1.040-6, 2009. Disponível em: https://doi.org/10.1016/j.aap.2009.06.017.

OMS. “A Declaração de Jacarta sobre Promoção da Saúde no Século XXI”. 1997. Relatório. Disponível em: http://www.who.int/healthpromotion/conferences/previous/ jakarta/en/hpr_jakarta_declaration_portuguese.pdf. Acesso em: 11 jul. 2019.

PACHECO, Elsa. "Alteração modal e política de transportes no NW português”. Portugal: Territórios e Protagonistas, Universidade do Minho Ed., Guimarães, p. 1-16, 2004.

PACIONE, Michael. Urban Geography: a global perspective. 3. ed. Routledge. Oxon: Routledge-Taylor \& Francis Group, 2009.

PARQUE AUTOMÓVEL SEGURO. "Parque Automóvel”. Lisboa: Parque Automóvel Seguro, 2008-2018. Estatística. Disponível em: https://www.asf.com.pt/NR/exeres/7D383D46-9431-416E-98C7-395B0A9E7080.htm. Acesso em: 3 mai. 2019.

RODRIGUE, Jean et al. The Geography of Transport Systems. Oxon: Routledge-Taylor \& Francis Group, 2006.

RPMS. “Apresentação”. Seixal: RPMS, s.d. a. Disponível em: http://redemunicipiossaudaveis.com/index.php/pt/apresentacao\#c. Acesso em: 12 jun. 2019.

. "Projetos dos Projetos Cidades Saudáveis". Seixal: RPMS, s.d. a. Disponível em: http://redemunicipiossaudaveis.com/index.php/pt/projetos\#c. Acesso em: 12 jun. 2019. 
SOUSA, Gonçalo. A georreferênciação dos acidentes de viação - o seu papel na prevenção de sinistros rodoviários: estudo de caso no Comando Territorial de Leiria (tese). Academia Militar, Lisboa, 2017.

THOMSON, J. M. Great cities and their traffic. Londres: Victor Gonzalez Ltd., 1977. UNITED NATIONS. "Mobilizing Sustainable Transport for Development: analysis and policy recommendations from the UN Secretary-General's High-Level Advisory Group on Sustainable Transport”. 2016. Relatório. Disponível em: https:// sustainabledevelopment.un.org/content/documents/2375Mobilizing Sustainable Transport.pdf. Acesso em: 11 jul. 2019

VLAHOV, David et al.. "Cities and health: history, approaches, and key questions". Academic Medicine, v. 79, n. 12, p. 1.133-8, 2004. Disponível em: http://doi. org/10.1097/00001888-200412000-00003.

WHO-EUROPE. "Health topics - Healthy Cities". s.d. a. Disponível em: http://www. euro.who.int/en/healthtopics/environment-and-health/urban-health/activities. Acesso em: 23 abr. 2019.

. "The top ten causes of death". Notícia. Disponível em: https://www.who.int/ news-room/fact-sheets/detail/the-top-10-causes-of-death. Acesso em: 27 mai. 2019. . Urban planning, environment and health: from evidence to policy action. Copenhagen: WHO-Europe, 2010.

WILLIAMS, Lisa Marie. Between health and place: understanding the built environment. Toronto: Wellesley Institute, 2013. 



\title{
Capítulo 10 \\ Mobilidade e segurança em contexto urbano: contributos para a redução do risco em populações idosas
}

\author{
Paulo Nuno Nossa \\ Anabela Mota-Pinto
}

O futuro da população mundial é urbano. Mais de metade da população mundial vive em áreas urbanas pelo que, a urbanização, determina a distribuição espacial da população constituindo uma das quatro megatendências demográficas, conjuntamente com o crescimento da população mundial [regional], o envelhecimento e as migrações internacionais (UN (d), 2019, p. 3).

Assistimos, de um modo persistente e continuado, ao aumento da população urbana nos níveis mundial e regional, sendo que, em 2020, estima-se que $56,2 \%$ população mundial resida em áreas urbanas. Essa tendência é historicamente liderada pelos países de rendimento elevado e, mais recentemente (1990 e seguintes), pelo grupo de países de rendimento médio-elevado (figura 1). 
Figura 1 - Evolução da população residente em áreas urbanas por região do globo (1950-2050)

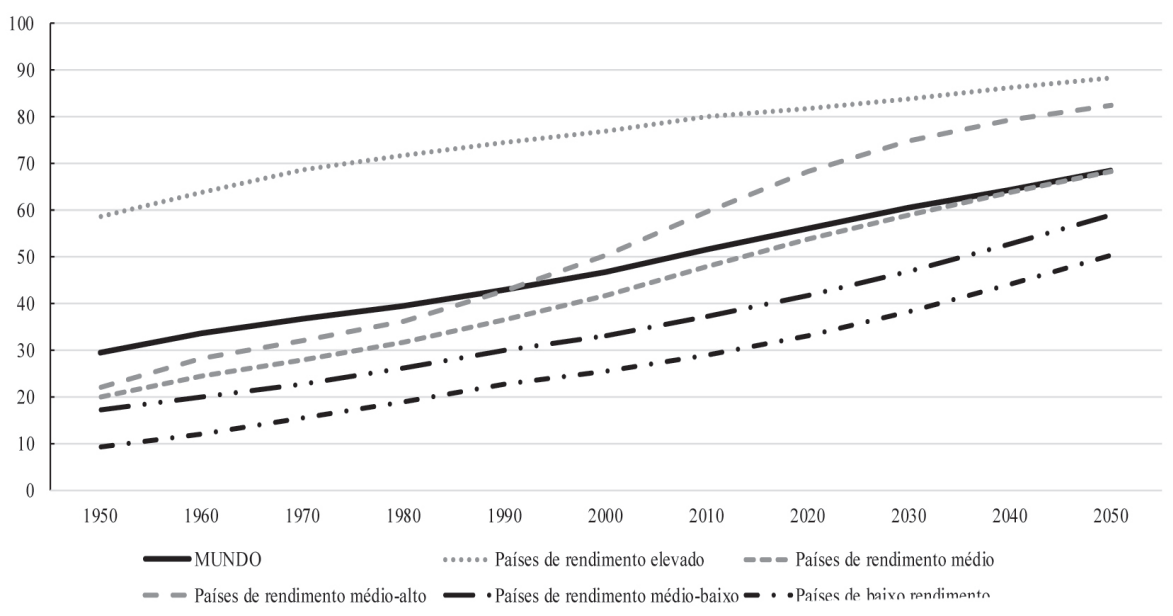

Fonte: UN-POP/DB/WUP/Rev.2018.

Organização: Autor

Apesar dos contrastes regionais que ainda podem ser observados, com catorze países a exibirem taxas de urbanização próximas dos 20\% (Exs.: Burundi, Maláui, Níger, Ruanda; 2018), as estimativas da Organização das Naçóes Unidas (ONU) para a população (2018) previam para esses territórios uma duplicaçáo da parcela de população urbana pelo que, em 2050, espera-se que 101 países tenham $80 \%$ da sua população a habitar em áreas urbanas (UN, 2019). Simultaneamente, ainda que de um modo regionalmente mais diferenciado, assistimos a uma tendência sustentada de redução das taxas de fecundidade (Taxa Global de Fecundidade: 3,2 nascimentos, 1990; 2,5 nascimentos, 2019; 2,2 nascimentos, 2050), a par do aumento da esperança de vida, contribuindo para a difusão do envelhecimento da população mundial. Em 2019, 1 em cada 11 pessoas no mundo terá 65 e mais anos (65 +anos; 9\%), esperando-se que, em 2050, essa razão seja de 1 em cada 6 pessoas (16\%). África do Norte, Ásia Ocidental, Ásia Central e do Sul, Ásia Oriental e do Sudeste, América Latina e Caribe são as regióes onde a parcela da população com 65 +anos deve duplicar entre 2019 e 2050 (UN, 2019). 
O forte crescimento da população urbana com idades 65 +anos tem gerado preocupação e discussão, quer em contexto acadêmico quer em contexto político, questionando-se se a cidade ou as áreas metropolitanas em geral são territórios aptos para potenciarem bem-estar a esses residentes. A OECD (2015) perspectiva para os países membros que, até 2050, ocorra um aumento de $25,1 \%$ de idosos a residir em áreas urbanas, sendo que, no presente, 43,2\% da população com mais de 65 anos já vivem em cidades (OECD, 2015, p. 5). Hoof et al. (2018, p. 2) retomam a discussáo sobre o potencial de bem-estar dos idosos na cidade, admitindo que, em determinadas circunstâncias: "Envelhecer no lugar (i.e., viver na comunidade, com algum nível de independência e não em cuidado residencial), é muitas vezes visto como um ideal". Autores como Smedley (2018, apud Hoof et al, 2018) admitem que a cidade pode ser "o lugar certo" e "amigável para os idosos" se, intencionalmente, esses territórios passarem por um processo de adaptação orientado para as necessidades desses residentes. A questão de se "envelhecer no lugar" como um ideal toca a problemática da identidade territorial dos grupos e, particularmente, as condições da sua coexistência, tema classicamente abordado pela geografia. Tal como nos recorda Haesbaert (1997), os espaços expressam mais do que a manifestação concreta do visível. Para Poche (1983, apud Haesbaert, 1997), os "espaços de referência identitária”, urbanos ou não, estão na base de leituras simbólicas que conjugam processos de apropriação estética, de pertença cultural coletiva e que contribuem para dar caráter e identidade a um território, no qual os sujeitos se fundem e, nesse caso, os sujeitos idosos se identificam, fruto de um processo mais ou menos longo de apropriação, constituindo-se como elementos vitais para o seu equilíbrio socioemocional ancorados nas redes de vizinhança, na (re)visitação de espaços de pertença e de "espaços sagrados", carregados de simbolismo, onde existe a capacidade de ver uma coisa diferente do que ela é. Naturalmente, a diversidade etária e social presente na cidade, e que é por definição uma das suas características, detém o potencial de gerar fricçôes entre as diversas identidades que a compóem, mas que, em alguns casos, se confrontam, apartando e segregando sutilmente as mais frágeis porque já menos adaptadas à sua tendência totalizante, podendo tornar incógnitos alguns dos seus residentes e rompendo mesmo com os vínculos sociais em razão de um conjunto de limitaçóes que advém com a idade e para as quais a "personalidade urbana”, na designação de Wirth (1979), está pouco disponível para fazer concessôes. 
Por outro lado, o nível de desenvolvimento econômico e social parece condicionar a pertença e a adequação dos territórios "amigos dos idosos". Hoof et al. (2018, p. 2), citando estudos produzidos por Easterlin et al. (2011) e Sorensen et al. (2014), sublinham que, no contexto da União Europeia (UE), em territórios com baixos níveis socioeconômicos, as áreas urbanas são mais favorecidas do que as áreas rurais em termos de rendimento, educação e estrutura ocupacional, potenciando uma melhor qualidade de vida para os idosos. Porém, em territórios com níveis de desenvolvimento socioeconômico mais elevado, as áreas rurais aproximam-se ou excedem os níveis de satisfação proporcionados pelas cidades para esses residentes.

Nesse contexto, assume particular relevância debater de que modo a mobilidade e a segurança habitacional da pessoa idosa pode ser alcançada e melhorada em contexto urbano, discutindo-se um conjunto de potenciais açóes orientadas para a redução de risco em populações idosas (65 +anos), seja em contexto de envelhecimento ativo, seja num contexto de promoção da saúde, e procurando ampliar ou conservar a sua autonomia.

\section{Envelhecimento ativo e saudável: mobilidade e permanência em contexto urbano}

O processo de envelhecimento demográfico, que se traduz num maior peso da população idosa $(65$ +anos) sobre a população jovem (0-14 anos), assume-se como uma conquista civilizacional, que é, cumulativamente, tributária da melhoria das condiçôes higiênico-sanitárias e assistenciais, com reflexo na mortalidade geral e infantil, de uma dieta alimentar mais adequada, acompanhada por avanços significativos na qualidade da habitação e do rendimento disponível, aos quais também se devem associar progressos na escolaridade, sobretudo feminina, e um aumento significativo da autonomia da mulher em diferentes domínios, que passam pela sexualidade, conjugalidade, emprego e participação social.

Ainda que evidenciando algum desfasamento temporal, Portugal e o Brasil buscam, a diferentes escalas, soluçóes para os desafios relacionados com o envelhecimento demográfico e o aumento da esperança de vida. Tal como é demonstrado na figura 2, em Portugal, o envelhecimento populacional concretizou-se na transição do século (2001), estando prevista ainda que com algum atraso, uma trajetória semelhante para o Brasil, em que estimativas da World 
Health Organization (WHO, 2010) apontavam 2037 como o ano em que o número de idosos ultrapassará a população jovem. Estima-se que, em 2025, o Brasil será o quinto país do mundo com maior número absoluto de idosos (33,4 milhóes) (OPAS/OMS, 2005). De acordo com um relatório publicado pelo Banco Mundial (2011) - Growing Old in an older Brazil: "A população idosa aumentará em cerca de $11 \%$ na total população em idade ativa em 2005, atingindo $49 \%$ até 2050 , enquanto a população em idade escolar diminuirá em cerca de 50\%, cifrando-se em 29\% da população em idade ativa em 2050 (Gragnolati et al.; 2011, p. XXVI).

Figura 2 - Projeção da relação percentual entre jovens e idosos em Portugal e Brasil (1950-2050)

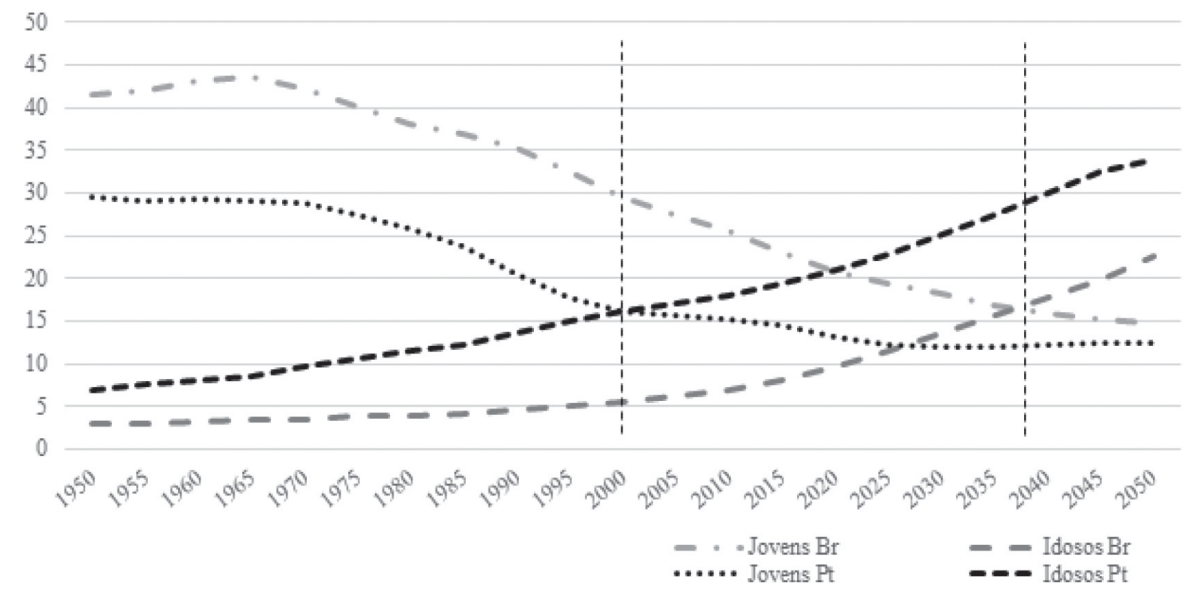

Fonte: WHO - World Population Prospects, 2010.

Organização: Sartor, 2014.

Embora não deva ser ignorada a abordagem crítica apresentada por Tornstam (1992), sobre o envelhecimento e o(s) estereótipo(s), que recai sobre os idosos nas sociedades ocidentais, ancorada no enraizamento da valorização do trabalho (sociedade industrial e pós-industrial), da produtividade econômica e do "bom envelhecimento", que, em alguns casos, remete de um modo falacioso para uma procura arrebatada de juventude eterna, em que o envelhecimento e os seus "efeitos associados" são apresentados como uma doença que é preciso combater (Blech, 2006), o conceito de envelhecimento ativo, hoje defendido pela OMS como Plano de Açáo Global e promovido 
pelos Estados no nível de políticas, evidencia um conjunto de objetivos cuja bondade e benefício merece ser averiguada.

O conceito de atividadelativo, que quase se "opóe” ao declínio físico gerado pelo envelhecimento biológico, foi inicialmente defendido por Robert Havighurst (1961) e adotado pela OMS no final dos anos 1990, demonstrando a existência de vantagens mensuráveis, físicas, emocionais e psicológicas, para os idosos, caso se mantivessem ativos e socialmente integrados, condiçóes essas que contribuíam para retardar o processo de envelhecimento e melhorar a qualidade de vida. Essa posição surge como reação ao paradigma de desinvestimento e conformação da pessoa idosa, atribuído a Cumming e Henry (1961), conhecido por Disengagement theory of aging, assente em nove postulados, nos quais, entre outros, se reconhecia passivamente que, sendo o envelhecimento uma etapa inevitável, o processo de declínio das aptidóes físicas e o estreitamento das relaçôes sociais consistiam num percurso natural e inelutável, resultando na inata e natural diminuição da interação entre o idoso e os outros no sistema social em que estava inserido.

O moderno conceito de envelhecimento ativo coloca novos desafios para a saúde e para os gestores urbanos, uma vez que é entendido como:

Um processo contínuo de otimização das oportunidades para a saúde, participação e segurança, contribuindo para a melhoria da qualidade de vida à medida que as pessoas envelhecem, bem como do seu processo de desenvolvimento e manutenção da capacidade funcional, cooperando para a construção do conceito de bem-estar da pessoa idosa, sendo a capacidade funcional o resultado da interação das capacidades intrínsecas da pessoa (físicas e mentais) com o meio (DGS, 2017, p. 6, WHO, 2015).

Como facilmente se infere, o que aqui se projeta é a construção de condiçóes capazes de possibilitarem a participação contínua na vida social, econômica, cultural, espiritual e cívica, indo para além da mera possibilidade de ser física e profissionalmente ativo. $\mathrm{O}$ envelhecimento ativo baseia-se no reconhecimento dos direitos humanos e no respeito pelos princípios de independência, dignidade, assistência, participação e autorrealização (WHO, 2015). Assim, o envelhecimento ativo assume-se como um conceito mais abrangente do que o envelhecimento saudável, pois compreende o processo de otimização das oportunidades em saúde, 
participação e segurança, sendo a manutenção da capacidade funcional um aspecto instrumental ${ }^{1}$ crucial, com implicaçóes diretas no contexto de bem-estar, tributário de múltiplas interaçóes entre o idoso/a e o meio (OPAS/OMS, 2005). Garantir os contextos adequados para estimular o envelhecimento ativo emerge como um imperativo ético que congrega políticas transversais, envolvendo estratégias de atuação multidisciplinares, flexíveis e de proximidade, que permitam que todas as pessoas idosas possam desfrutar de uma vida ativa e saudável:

As condições de saúde são determinantes no envelhecimento ativo, mas a promoção do envelhecimento ativo não se restringe à promoção de comportamentos saudáveis. É essencial considerar os fatores ambientais e pessoais, como os determinantes económicos, sociais e culturais, o ambiente físico, o sistema de saúde, o sexo e outros determinantes (WHO, 2002). A família, a comunidade e a sociedade têm um forte impacto na forma como se envelhece (Cabral et al., 2013).

Na generalidade das sociedades ocidentais que evoluíram para o último estádio de transição em saúde (fase IV), à medida que progredimos etariamente (>50 anos), as principais causas da carga de doença e de mortalidade estão relacionadas com doenças não transmissíveis (DNT’s). Nos países com elevado indice sociodemográfico (IDS), a hierarquia das principais causas de morte em população 50-69 anos é dominada pelas DNT's que ocupam os cinco primeiros lugares, fato que se mantém inalterado na população com 70 e mais anos, exceto na 5 . $^{a}$ posição, onde emerge uma doença infeciosa - Infecção Respiratória e Tuberculose com comorbidades graves que agravam o risco de morte por patologia cardíaca no idoso (figura 3).

\footnotetext{
A capacidade funcional (como capacidade ventilatória, força muscular e débito cardíaco) aumenta durante a infância e atinge seu máximo nos primeiros anos da vida adulta, entrando em declínio em seguida. A velocidade do declínio, no entanto, é fortemente determinada por fatores relacionados ao estilo de vida na vida adulta - como, por exemplo, tabagismo, consumo de álcool, nível de atividade física e dieta alimentar - assim como por fatores externos e ambientais. [...] A aceleração no declínio pode sofrer influências e ser reversível em qualquer idade através de medidas individuais e públicas (OMS, 2005, p. 15).
} 
Figura 3 - Principais causas de morte em países com elevado índice sociodemográfico, em população $\geq 50$ anos (2017; Óbitos $10^{5}$ hab.)

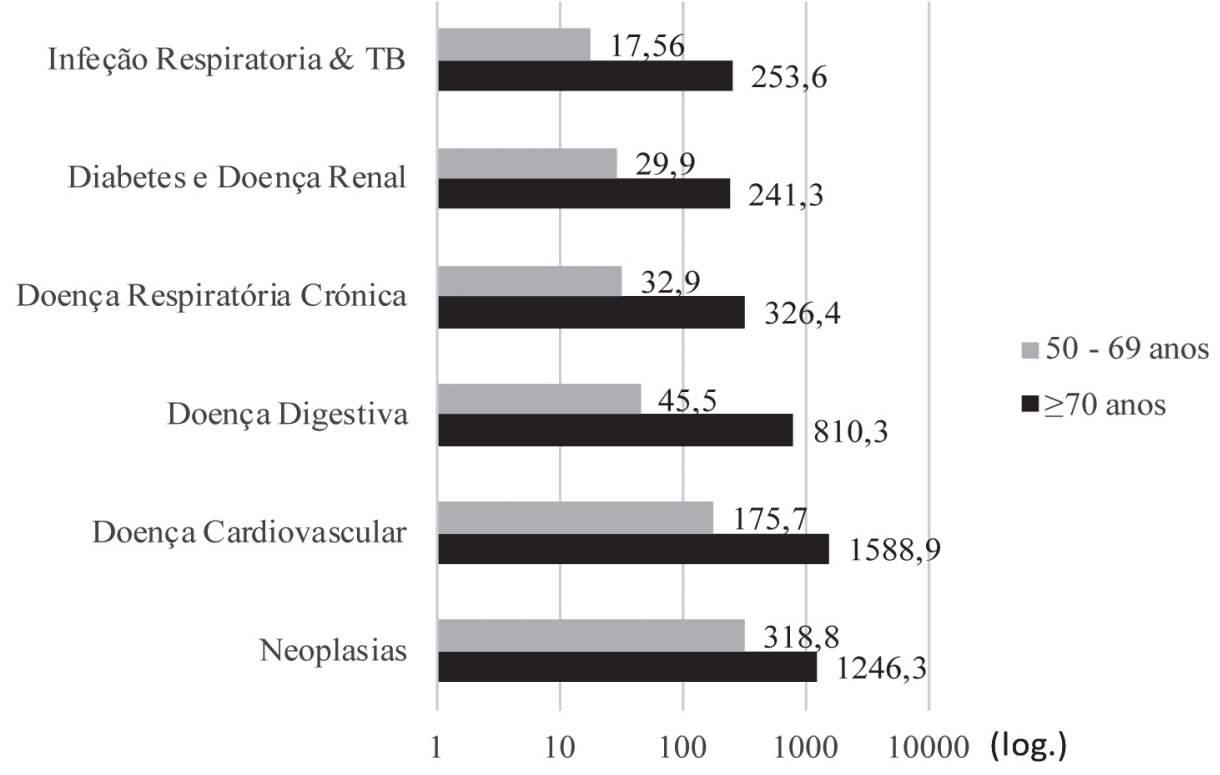

Fonte: Institute for Health and Evaluation - GBD 2017; University of Washington.

Organização: Autor.

Nesse contexto, as linhas orientadoras para a prevenção primária nessa categoria de patologias (DNT) passam pelo equilíbrio da responsabilidade individual com programas transversais de envelhecimento ativo que interagem com os determinantes desse envelhecimento (OPAS/OMS, 2005) (figura 4). 
Figura 4 - Determinantes do envelhecimento ativo

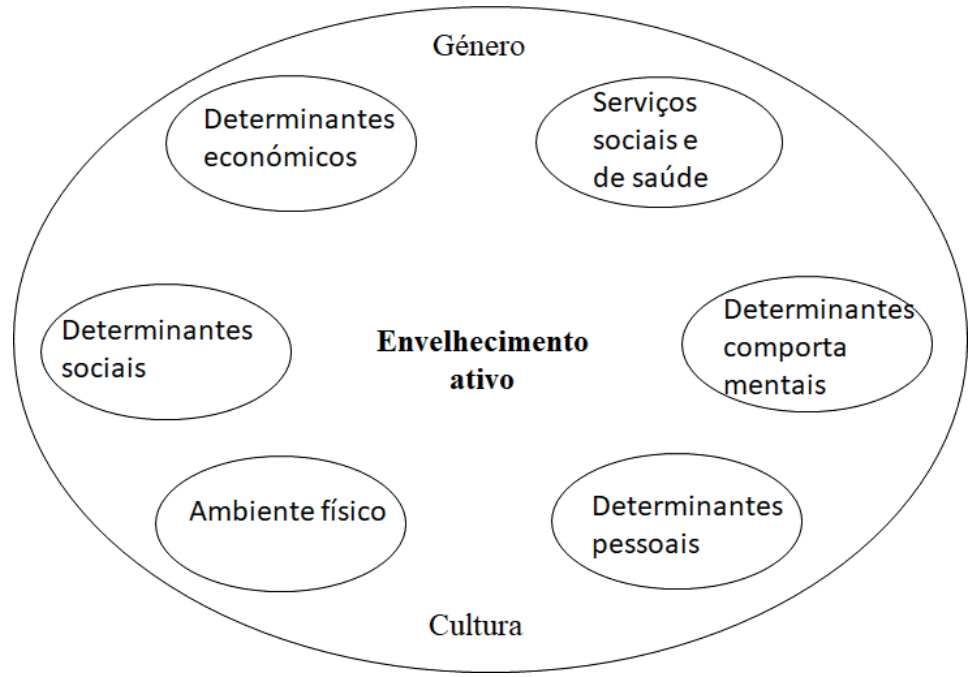

Fonte: OPAS/OMS, 2005, p. 19.

Indo para além de determinantes transversais, como a cultura e o gênero, interessa-nos, nesse contexto, focalizar o papel que fatores comportamentais $e$ ambiente físico têm na adoção dos estilos de vida ${ }^{2}$ saudáveis em contexto urbano, onde o aumento da proporção de moradores com 65 +anos acarreta riscos de segurança e de exclusão. Simultaneamente, o processo de êxodo rural da população mais jovem pode resultar num aumento e isolamento das pessoas idosas não só em zonas de baixa densidade demográfica, mas também em áreas urbanas, cujos contornos importa compreender e mitigar.

No nível da prevenção de DNT’s, encontramos na literatura diversas associações positivas entre a atividade física ${ }^{3}$, o exercício físico e a saúde

2 Estilo de vida: conjunto de hábitos e comportamentos de resposta a situaçóes do dia a dia, aprendidos por meio do processo de socializaçáo e constantemente reinterpretados e testados ao longo do ciclo de vida e em diferentes situaçóes sociais (Programa Nacional de Saúde Escolar, 2006, p. 15).

3 Atividade física: contempla qualquer movimento realizado pela musculatura esquelética do corpo (os principais músculos) que resulte num dispêndio energético acima dos valores de repouso. Exercício físico compreende toda a prática consciente de atividade física, realizada com um objetivo específico (ex.: melhorar a saúde) e bem delineada no tempo, com ou sem prescriçáo. É geralmente uma prática planeada. Os idosos devem fazer pelo menos 150 minutos de atividade física aeróbica de intensidade moderada durante a semana ou fazer pelo menos 75 minutos de 
humana em qualquer idade (Lagerros, 2007; Magalhães et al., 2016; Pereira, 2017; Rebelo- Marques et al., 2018). No caso da pessoa idosa (65 +anos), também existem evidências de que a atividade física está associada com maiores níveis de capacidade funcional, menor risco de quedas e melhor função cognitiva. Em idosos com mobilidade reduzida, reconhece-se que a participação em atividade física, pelo menos três dias por semana, contribuiu para melhorar o equilíbrio, devendo a atividade aeróbica ser realizada em períodos de pelo menos 10 minutos de duração, num total de 150 minutos semanais (WHO, 2010, p. 8 e 30).

Como forma de potenciar a atividade física, num contexto de prevenção primária em espaço urbano, o Movimento das Cidades Saudáveis (1986), nomeadamente a partir da sua Fase IV (2003-2008), reforçou a necessidade de se desenvolver um plano de saúde para as cidades que desenhasse um conjunto de respostas orientadas paras as necessidades dos grupos mais vulneráveis, nos quais se incluem os idosos, incorporando conceitos de desenvolvimento sustentável, vida ativa e governança participativa e democrática, propondo quatro grandes áreas de atuação: envelhecimento saudável, planeamento saudável, avaliação do impacto na saúde e atividade física e vida ativa (Marques da Costa, 2013; WHO, 2017; Nossa, 2017; Sá-Moura et al., 2018). Assim, as metas desenhadas para a concretização da Fase VI do projeto Cidades Saudáveis (2013-2018) passaram por um reforço das estratégias de inclusão e participação, objetivando a correção de assimetrias de poder, nesse caso particular, envolvendo adultos idosos. Como reconhece Phillipson (apud Pereira, 2015), as cidades estão pensadas para quem está em idade ativa: "Se observarmos à escala local, à escala do bairro, $80 \%$ do tempo das pessoas com 70 +anos é passado em casa e na vizinhança”.

Todavia, deve referir-se que, em períodos anteriores, nomeadamente a partir da década de 1980, mais por via de preocupaçóes provenientes do planeamento urbano e menos por via da prevenção em saúde, vários movimentos urbanísticos produziram uma abordagem crítica à necessidade de se desenharem cidades sustentáveis, capazes de combaterem a expansão urbana dominante - urban sprawl - marcada por elevados impactos ambientais associados ao crescimento horizontal da cidade e das periferias economicamente

atividade física aeróbica de intensidade vigorosa durante a semana ou uma combinação equivalente de atividade moderada e de intensidade vigorosa (ENPAF-DGS, 2016). 
segregadas, bem como à utilização crescente do automóvel como forma privilegiada de deslocação, agravando modos de vida progressivamente mais sedentários, que ganharam crescente relevância com os modos de vida industriais (Pereira, 2017). Numa fase anterior, na década de 1970, o conceito urbanístico Livable Communities já havia aparecido nos Estados Unidos da América (EUA), enfatizando as vantagens decorrentes do desenho da cidade à escala humana, fomentando a diversidade de usos do solo, diversidade de transportes, favorecendo formas de mobilidade suave, nas quais se incluem a deslocação pedonal, bem como a criação de espaços públicos apropriáveis e de bairros com “caráter”. Tal como esclarece Pereira (2017, p. 19):

Este movimento promove, assim, a caminhabilidade, a criação de assentamentos urbanos diversificados quer na sua estrutura funcional como na sua forma, que procura através da criação de uma vasta gama de equipamentos e estruturas urbanas tornar as cidades mais habitáveis.

Os conceitos de habitável (livable) e caminhável (walkable) sofreram uma apropriação e uma deriva, figurando, progressivamente, como sinônimos de estratégias promotoras de espaços amigáveis para idosos, onde a habitabilidade e a caminhabilidade são condiçôes indispensáveis à geração de bem-estar e à manutenção de uma atividade física necessária para manter níveis de mobilidade, equilíbrio e cognição benéficos para o processo de envelhecimento ativo.

De acordo com Hwang e Ziebarth (2015), o termo habitável (livable), após a apropriação do conceito proveniente do planeamento urbano, é hoje extensamente utilizado nos Estados Unidos da América (EUA) para designar comunidades sustentáveis e verdes (Livable communities), onde os principais focos dos instrumentos jurídicos de planeamento têm como objetivo gerir de um modo mais eficiente e sustentável questóes relacionadas com o uso do solo, crescimento (sub)urbano de baixa densidade ou expansão urbana. A eficiência alcançada nesses domínios beneficia, de modo direto e indireto, o paradigma do envelhecimento ativo:

Ao planear uma comunidade habitável, a eficiência do transporte é estabelecida, os ativos locais são desenvolvidos e os bairros populares e habitáveis e acessíveis são enfatizados (Geller, 2003). Todo esse contexto pode ajudar as pessoas mais 
velhas a realizarem atividades quotidianas com opções de mobilidade compatíveis com as suas necessidades que mudam com o tempo.

[...]

A habitabilidade [livability] também está ligada à criação de mais oportunidades para os idosos ficarem mais tempo em sua própria comunidade (Associação Nacional de Agências de Área Envelhecimento, 2007 apud Hwang e Ziebarth, 2015, p. 208, tradução livre).

Tal como enfatiza a American Association of Retired Persons (AARP, 2005), uma comunidade habitável tende a oferecer habitação acessível e apropriada, recursos e serviços comunitários de apoio e opções de mobilidade adequadas para facilitar a independência pessoal e o envolvimento comunitário dos moradores. Para que esse conceito seja definitivamente conquistado e estendido a todas as idades (livable communities for all ages), existem seis áreas-chave que devem ser desenvolvidas:

1. Acesso a habitação variada (unidades de alojamento acessório; partilha residencial), apropriada e acessível (física e economicamente: gabinetes técnicos de adaptação residencial; custo despendido pelo agregado familiar com um residente $65+$ anos $\leq 30 \%$ rendimento anual);

2. Ajustar o ambiente físico de modo a promover a inclusão e a acessibilidade;

3. Garantir transporte seguro, apropriado e acessível (física e economicamente);

4. Garantir o acesso aos principais serviços prestadores de cuidados;

5. Promover oportunidades de trabalho, educação e voluntariado;

6. Encorajar a participação em atividades cívicas, culturais, sociais e recreativas (Stanford Center on Longevity, 2013, p. 6, tradução livre).

De modo semelhante, o conceito de caminhabilidade/pedonalidade (walkability), hoje associado a sustentabilidade (uso racional dos modos de transporte) e qualidade de vida urbana, também sofreu uma apropriação e uma deriva, qualificando-se como um conceito transdisciplinar. Sendo originário da tributação imobiliária (Ghidini, 2011), passou a ser usado para caracterizar bairros e cidades, até figurar nas modernas recomendações de saúde pública, ganhando crescente 
relevância à medida que a associação entre o sedentarismo, a obesidade e as comorbidades ganharam espaço na agenda de saúde.

De acordo com Ghidini (2011), o aumento da tributação sobre a propriedade imobiliária urbana ocorrida em Ottawa (1992), tendo como base os valores de mercado, levou a que alguns proprietários questionassem a sua adequabilidade e proporcionalidade e argumentando que, em muitos bairros, a necessidade e o uso de infraestruturas de circulação, subsidiadas por impostos imobiliários, era significativamente inferior, pois a maior parte dos habitantes desses bairros simplesmente caminhava para efetuar as suas deslocações quotidianas. Perante esse desafio/oportunidade, Chris Bradshaw (1993, apud Ghidini, 2011, p. 7) pensou em servir-se da possibilidade de mensurar o potencial de deslocação pedonal no quarteirão ou no bairro, usando-o como um sistema de avaliação ou índice portável para calcular o valor tributário em razão das deslocações pedonais que pressionavam aos residentes - caminhabilidade. Inicialmente, Bradshaw (1993) utilizou 10 itens como indicadores de mensuração de "caminhabilidade":

1. Densidade de pessoas nas calçadas;

2. Estacionamento para veículos;

3. Disponibilidade e quantidade de bancos (mobiliário urbano) utilizáveis pelos habitantes do bairro;

4. Oportunidade para estabelecer relaçóes sociais (conversar, conhecer...);

5. Idade com que a crianças podem fazer percursos pedonais autônomos;

6. Avaliação feminina da segurança do bairro;

7. Sensibilidade do serviço de trânsito local;

8. Quantidade de locais importantes do bairro que possam ser enumerados pela vizinhança;

9. Estacionamento, acessibilidade e disponibilidade;

10. Calçadas: tamanho e conservação (Ghidini, 2011, p. 9).

Hoje, o conceito contemporâneo de caminhabilidade refere-se à capacidade que uma determinada área urbana apresenta para suportar, promover ou incentivar o caminhar, sendo medido frequentemente por meio de cinco características (5 D): densidade; diversidade; design; acessibilidade ao destino; e distância aos transportes (Pereira, 2017, p. 33): 
A densidade refere-se aos atributos de interesse por área geográfica, a diversidade à mistura de usos do solo, o design diz respeito ao desenho das ruas, a acessibilidade dos destinos refere-se à disponibilidade de destinos para viajar para, como e.g. comércio, serviços... e a distância aos transportes corresponde à distância física aos transportes públicos. Outras características, como a estética ou nível de segurança de um determinado espaço, que se considera como podendo também promover o caminhar, são frequentemente descritas como fazendo parte do nível de caminhabilidade de uma determinada área.

À medida que os modelos ecológicos alcançaram relevância na interpretação e compreensão dos comportamentos em saúde, enfatizando, entre outros, a influência da dimensão ambiental e política sobre o comportamento, como estando implicada na compreensão da motivação para desenvolver atividade física (Pereira, 2017; Edwards e Dulai, 2018), a dimensão qualitativa do ambiente construído, nomeadamente o conceito de caminhabilidade, entrou na equação dos fatores potenciadores de locomoção. Para Ghidini (2010, p. 2), a caminhabilidade é uma qualidade do lugar, e essa característica deve influenciar a motivação dos sujeitos, induzindo mais pessoas a adotarem a pedonalização como uma forma frequente de mobilidade para a resolução de tarefas e necessidades quotidianas (instrumental walking), ou para melhorar os seus índices de saúde física e mental (health or leisure walking), ao mesmo tempo que contribui para o (r)estabelecimento das relaçóes de interdependência com as ruas e com os bairros. Para além dos benefícios físicos que estão associados ao caminhar ou andar de bicicleta (cycling), Edwards e Dulai (2018) admitem que, indiretamente, bairros mais acessíveis também têm sido associados a uma maior coesão e conectividade de vizinhança, menor isolamento social, maior segurança e menor criminalidade.

No entanto, existem algumas preocupaçóes sobre a capacidade de caminhar como um construto, particularmente no que se refere aos idosos (65 tanos), fato que adiante vamos discutir. 


\section{A caminhabilidade como estratégia para promoção da saúde na pessoa idosa}

Reconhecendo-se que um dos objetivos do projeto Cidades Saudáveis reside no combate à segregação dos residentes vulneráveis, importa, pois, compreender que as medidas preconizadas para promover o bem-estar e a qualidade de vida não devem estar exclusivamente orientadas para um segmento demográfico específico. Tal como sublinham Hoof et al. (2018, p. 3), uma cidade verdadeiramente amiga das pessoas idosas não está enfocada na satisfação das necessidades de uma geração específica, mas deve incluir e abranger todas as geraçôes: "Idealmente, os lugares para viver devem ser organizados para facilitar a interação social e promover um sentido da comunidade".

Todavia, são diversos os autores que mencionam a necessidade de refletirmos criticamente sobre a demonstração dos benefícios que a caminhabilidade e as práticas de sociabilização em espaço público têm sobre a população idosa (Van Cauwenberg et al., 2011; Van Holle et al., 2014; Hwang e Ziebarth, 2015; Edwards e Dulai, 2018), encontrando metodologias de ajuste para identificação e avaliação das suas necessidades específicas, sobretudo por meio de estudos qua avaliem os ambientes de forma objetiva e subjetiva.

Apesar de ser inquestionável a lista de benefícios que a atividade física têm para a saúde da pessoa idosa, nomeadamente na manutenção de níveis de mobilidade, equilíbrio e cognição, para além da redução do risco para algumas patologias (doença coronária, hipertensão, diabetes tipo 2, carcinoma do cólon e da mama, entre outras) (WHO, 2010), a literatura é menos abundante em estudos que examinem a associação específica entre a caminhabilidade e os benefícios da atividade física de baixa intensidade para a populaçôes idosas, tendo sido publicados pela primeira vez em 2014 os resultados de um estudo envolvendo a população europeia, realizado por Van Holle et al. (2014).

Uma revisão da literatura sobre a temática da caminhabilidade $v$ s atividade física produzida por Orstad (2017, apud Edwards e Dulai, 2018) sublinha a importância metodológica de se compararem medidas objetivas de fatores ambientais que influenciam a caminhabilidade e a atividade física com medidas subjetivas, nomeadamente por meio de questionários validados para a idade e gênero: "o ambiente de vizinhança percebido e o ambiente de vizinhança medido objetivamente são construtos relacionados, mas distintos e essa distinção explica a variação única na atividade física” (Orstad, 2017, apud Edwards e Dulai, 2018, p. 2). 
Van Cauwenberg et al. (2011) havia alertado para as desigualdades de relação encontradas entre diferentes grupos etários quando avaliavam atividade física - ambiente construído. A associação mais fraca verificada em grupos de idosos demonstrava a necessidade de se produzirem avaliaçôes mais detalhadas do ambiente físico para que melhor se conheça a relação das pessoas idosas com a atividade física. Caminhar por lazer é uma forma relativamente comum de atividade física encontrada entre idosos (Van Holle et al., 2014), todavia a presença de obstáculos físicos, como escadas, piso irregular ou ambientes pouco iluminados e inseguros ao longo do percurso, podem ser particularmente problemáticos para uma população que detém níveis de restrição na sua mobilidade:

As medidas geográficas [utilizadas] podem não capturar variações locais nas características ambientais, que influenciam o modo como as pessoas mais velhas são capazes de se deslocar no seu ambiente externo ou formularem opções.

[...] As perceções subjetivas levam em consideração a facilidade ou dificuldade de mobilidade no ambiente tendo como base vários atributos pessoais: saúde física ou mental; medo de cair; confiança e domínio do meio ambiente e a perspetiva de possíveis benefícios (Edwards e Dulai, 2018, p. 2, tradução livre).

No que diz respeito aos principais resultados alcançados pelo primeiro estudo europeu produzido por Van Holle et al. (2014), envolvendo a população idosa belga $(65+$ anos), no qual se avalia a caminhabilidade $v$ s atividade física, releva o fato de que, para além das qualidades ambientais que qualificam a caminhabilidade, fatores como rendimento e ocupação influenciam a frequência, duração e intensidade dessa mesma atividade física, predominando, nessa faixa etária, a atividade física de baixa intensidade, cuja prática decresce em pessoas com menores rendimentos e maior ocupaçáo adicional na reforma.

Nessa investigação, observou-se que os idosos residentes em bairros de caminhabilidade mais elevada acumulavam semanalmente mais minutos de atividade física pedonal associados com a satisfação de rotinas quotidianas (instrumental walking), evidenciando uma associação positiva e esperada com atividade física de baixa intensidade, quando comparados com os seus pares residentes em bairros de baixa caminhabilidade. Van Holle et al. (2014, p. 6) justificam esse fato por, presumivelmente, os moradores de bairros de baixa caminhabilidade gastarem mais tempo em atividades realizadas em ambientes fechados, como limpar ou 
realizar tarefas domésticas, uma vez que essas atividades podem ser fisicamente menos exigentes e de duração mais curta do que as atividades realizadas ao ar livre envolvidas nas deslocaçóes quotidianas. Por outro lado, idosos residentes em bairros de renda e caminhabilidade mais elevada evidenciavam níveis mais altos de atividade física de baixa intensidade, objetivamente medidos, do que os seus pares residentes em bairros menos favorecidos, com diferenças estatisticamente significativas, ao passo que estes últimos acumulavam mais minutos em práticas recreacionais envolvendo atividade física moderada ou vigorosa.

Ainda de acordo com os investigadores (Van Holle et al., 2014), 65\% dos participantes admitiram acumular pelo menos duas limitaçôes físicas, com consequentes implicaçóes na realização de atividades instrumentais da vida diária (AIVD: ir às compras, gerir dinheiro, uso de telefone, limpar, cozinhar, usar transportes), fato que pode justificar a maior prevalência de atividade física de baixa intensidade associada a deslocaçôes necessárias para a rotina diária:

O acesso a destinos (por exemplo, lojas, serviços públicos, locais de interação social) nas proximidades da residência podem constituir um correlato ambiental essencial por de trás dessa relação significativa. [...] No entanto, ter destinos próximos refere-se apenas a um dos três componentes da capacidade de mobilidade (ou seja, diversidade do uso do solo), enquanto que o índice de caminhabilidade também inclui a conectividade de ruas e a densidade residencial. Ambos os fatores têm sido associados positivamente com a caminhada relacionada ao transporte de idosos em alguns estudos anteriores (Van Holle et al., 2014, p. 6).

Embora, neste estudo, a qualidade de caminhabilidade do lugar não estivesse associada com práticas de atividade física para lazer ou recreaçáo, ou com qualquer uso de mobilidade em bicicleta (cycling), fato provavelmente consequente com as incapacidades físicas relatadas pelos participantes, Van Holle et al. (2014) alertam para o potencial significado que outros aspectos do ambiente físico podem ter na explicação da prática de atividade física recreativa entre idosos, como a presença de parques, ou espaços de circulação e níveis de tráfego seguros. Adicionalmente, fatores socioecológicos que estão para além do ambiente físico, como o apoio social ou a força da rede social onde o sujeito se insere, podem estar mais relacionados com a atividade física de recreação nessa faixa etária. 


\section{A importância da segurança da pessoa idosa no ambiente físico}

De acordo com a WHO (2002), a segurança é um dos pilares do envelhecimento ativo e saudável, sendo essencial para a manutenção da capacidade cognitiva e funcional das pessoas idosas. Nesse contexto, o ambiente físico detém um forte impacto na segurança das pessoas idosas, quer em espaços públicos ou no domicílio, sendo importante produzir estratégias e programas orientados para a adaptação responder às necessidades e limitaçôes deste público-alvo (DGS, 2017).

De acordo com a literatura (Gyllencreutz e Saveman, 2015), metade de todas as quedas entre idosos ocorrem em ambientes exteriores (públicos ou privados), sendo que a sua maioria está associada com atividades de mobilidade quotidiana, como caminhar, andar de bicicleta e participar em atividades de socialização.

Tal como já foi mencionado, para além das condiçóes objetivas relacionadas com a caminhabilidade, importa que as condiçóes físicas dos traçados, dos espaços públicos e das residências sejam seguras e não coloquem em risco a pessoa idosa. De acordo com o Programa Nacional de Prevenção de Acidentes (2012), sabe-se que, em Portugal, o grupo etário de 65 +anos representa 14\% das vítimas de acidentes de trânsito, sendo que o fator idade contribui de forma significativa para a mortalidade em geral e representando os idosos $29 \%$ dos peões mortos. Relativamente aos acidentes domésticos, 14\% das vítimas são idosos, maioritariamente mulheres, uma vez que o espaço doméstico é o principal local de ocorrência de sinistralidade.

No caso dos EUA, de acordo com o Center for Disease Control and Prevention (CDC), citando um relatório de 2012 produzido pelo HCUPnet ${ }^{4}$, contabilizam-se 3 milhôes de atendimentos de emergência gerados por quedas de pessoas idosas, o que corresponde a, aproximadamente, 800 mil internamentos/ano. Por esse motivo, as questóes que envolvem a segurança da pessoa idosa em espaço urbano devem envolver quer o espaço público - adaptaçóes da rede de transporte coletivo, sinais de trânsito, qualidade das calçadas entre outros -, como também o espaço doméstico, que, progressivamente, deve estar adaptado às condiçóes físicas e cognitivas da pessoa idosa (Bodstein et

${ }^{4}$ HUCUPnet - Health Care Cost and utilization Project. Disponível em: https://hcupnet.ahrq. gov/\#setup. 
al., 2014). Para além dos efeitos físicos e imediatos associados às quedas nos idosos, esse tipo de acidente acarreta consequências psicológicas significativas, quer para o idoso quer para os seus cuidadores ou familiares. De acordo com Carmo (2014), mesmo não havendo lesão física associada à queda, o "medo de cair", que se caracteriza por: "Uma preocupação exagerada de queda que leva ao excesso de restrição de atividades" (Lach, 2005, p. 45, apud Carmo, 2014, p. 26), pode estar associado a um conjunto de consequências que impactam negativamente a funcionalidade e a qualidade de vida da pessoa idosa:

- Diminuição da autoconfiança e redução da interação social;

- Restrição do nível de atividade;

- Perda de autonomia;

- Confusão e depressão.

Importa, pois, ampliar esforços para garantir um ambiente físico seguro para a pessoa idosa, de modo a reduzir os efeitos incapacitantes que podem secundar esse tipo de ocorrência: "No que temos sido menos bons é a pensar nos efeitos incapacitantes da doença. Temos de pensar mais na redução da incapacidade. Muitas pessoas têm mais medo de ficar incapacitadas, dependentes, do que de morrer" (Jagger, 2018, apud Pereira, 2018).

Um estudo realizado na Suécia, com recurso a coinvestigação por meio do uso de grupos focais envolvendo idosos ativos, publicado por Gyllencreutz e Saveman (2015), com o objetivo de melhorar a segurança de espaços públicos frequentados por idosos em percursos pedonais habituais, sugeriu às autoridades municipais a adoção de um conjunto de medidas, entre as quais se destacam:

1. Dotar os percursos urbanos [partilhados] de sinalização consistente, informando adequadamente pedestres e ciclistas;

2. Melhorar a iluminação ambiente noturna em trajetos pedonais e clicáveis, ampliando a sensação de segurança para além da introdução de sinalizaçáo horizontal por meio de leds incrustados no pavimento;

3. Melhorar a aderência nas transiçóes de plano em calçadas, evitando degraus, mas colocando piso não escorregadio, com limitaçáo de velocidade paras os ciclistas em trajetos partilhados; 
4. De acordo com a estação do ano, a limpeza das calçadas/trajetos deveria ser melhorada, tornando-as menos escorregadias, fato que obriga muitos pedestres a procurarem o eixo pedonal central para contrariar esse efeito.

De acordo com os participantes, a adoção dessas medidas, a aplicar em espaços públicos urbanos, ampliaria o grau de atividade física por meio de caminhada destinada a organizar a sua rotina diária.

De igual modo, os níveis de segurança dentro das habitaçóes onde residem pessoas idosas também devem ser avaliados e progressivamente adaptados às suas limitaçóes e necessidades. Para além de um conjunto de itens de segurança externos (iluminação, aderência do piso e calçado adequado), alguns autores identificam fatores de risco endógenos do envelhecimento com impacto no risco de queda: diminuição da acuidade visual e auditiva, mudança de postura e má mobilidade, uso de medicação ou polimedicação (Oliveira et al., 2017).

Num estudo realizado na área urbana de Coimbra, Portugal, e publicado por Almeida et al. (2019), envolvendo uma amostra de 115 idosos com a idade média de 80,4 anos (min. 65 anos, max. 98 anos), verificou-se que 48,7\% (n= 56) dos sujeitos viviam sozinhos. Observou-se que apenas 22,6\% ( $\mathrm{n}=26)$ dos participantes ainda detinham autonomia para efetuar deslocaçóes quotidianas, utilizando preferencialmente transporte público. Dos idosos não autônomos em termos de mobilidade quotidiana, 24,3\% ( $\mathrm{n}=28)$ dependiam da família/ amigos para satisfazer as suas necessidades de deslocação, e 48,7\% ( $\mathrm{n}=56)$ dependiam de instituiçóes cuidadoras de idosos para suprir essa necessidade. Esse valor pode ser justificado pelas restriçóes de mobilidade que enfrentavam $14,8 \%(\mathrm{n}=17)$ dos idosos participantes, necessitando diariamente do uso de andarilho ou cadeira de rodas para se moverem. No total, 46,1\% da amostra $(\mathrm{n}=53)$ não realizavam qualquer atividade física semanal, e apenas $9,6 \%$ realizavam atividade física com frequência adequada ( $\geq 3$ vezes por semana, pelo menos 20 minutos), ainda que de baixa intensidade.

Quando foi avaliada a segurança na habitação, verificou-se que 76,5\% $(\mathrm{n}=88)$ já havia sofrido algum tipo de queda, tendo esta ocorrido maioritariamente no espaço residencial $(41,7 \%, n=48)$, ao passo que $34,8 \%(n=40)$ declarram ter caído na rua. 
Nesse contexto, relativamente aos idosos que declararam já ter caído, $36,5 \%(n=42)$ informaram que esse incidente ocorreu nos últimos 12 meses. Quando foi pedida a apreciação subjetiva sobre a existência de algum tipo de limitação relacionada com esse tipo de acidente, 19,1\% ( $n=22)$ declararam ter ficado com algum tipo de sequela que implicava alteração da marcha ou da mobilidade (figura 5). Adicionalmente, encontrou-se uma relação significativa entre as AIVD e os prejuízos causados por quedas ( $\bigotimes 2=14,261 ; \mathrm{p}=0,027)$, com maiores níveis de dependência encontrados entre idosos com sequelas pós-queda, com alteraçóes na marcha ou na mobilidade e consequente aumento da incapacidade.

Figura 5 - Limitaçóes físicas geradas por quedas numa amostra de idosos

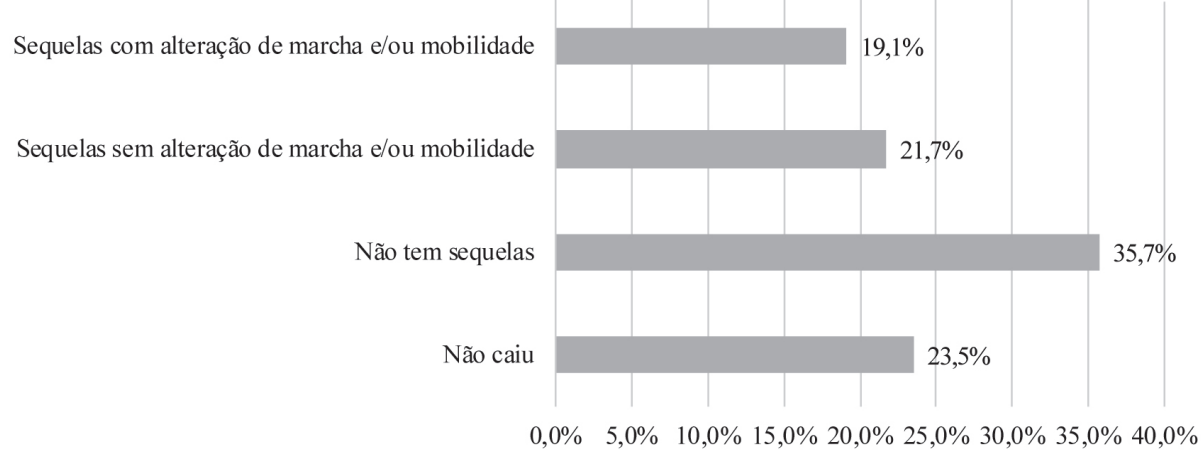

Fonte: Oliveira et al., 2019.

Nota: Amostra composta por 115 idosos residentes na área urbana de Coimbra, Portugal (2017).

De modo a minorar o risco de acidentes em espaço doméstico e correspondendo a boas práticas referenciadas pela OMS (2007) e pela American Association of Retired Persons (2005), identificamos em Portugal, no domínio das políticas públicas municipais, a autarquia de Pombal, que desenvolveu um programa de apoio à adaptação da habitação da pessoa idosa ou com incapacidade, com o objetivo de fomentar a capacidade de permanência autônoma na habitação da pessoa idosa ou com incapacidade, reduzindo riscos funcionais e adequando os espaços e as suas acessibilidades às suas restriçóes ou necessidades - Programa de Apoio Municipal para Adaptação e Requalificação de Habitaçôes (AMPARHA, 2016). Esse programa, em vigor no último quadriênio, tem como destinatários privilegiados idosos (65+anos) ou pessoas com 
incapacidade, que residam em habitação própria, arrendada ou cedida a título gratuito (comodato) e que evidenciem insuficiência econômica (rendimento per capita $\leq 2 \times$ IAS [Indexante de Apoio social= 435.76€] 2019). Os recursos financeiros afetos a esse programa encontram-se devidamente inscritos no Plano de Atividades Municipais, podendo o valor máximo de apoio por intervenção atingir os $2.500 €$ por candidatura anual.

Esse tipo de política pública municipal, baseado em boas práticas de apoio à autonomia da pessoa idosa e com deficiência, fomentando a sua autonomia e reduzindo o risco de acidente no anterior da habitação, constitui um exemplo que, depois de avaliado, deveria ser replicado e ampliado como instrumento de atuação "amigo da pessoa idosa e/ou com incapacidade".

\section{Considerações finais}

Demonstrou-se que, de um modo paulatino, o processo de envelhecimento demográfico segue uma tendência crescente de consolidação regional, observando-se uma prevalência superior nas áreas urbanas com consequências diretas na qualidade de vida dos residentes, na sua autonomia e no modo como estes organizam as suas rotinas quotidianas.

Desde a década de 1960, como reação ao modelo de crescimento urbano do pós-guerra que se antevia ineficaz e insustentável, que os conceitos de livable communities, entre outros, foram amplamente discutidos, transferindo os seus argumentos, em fase posterior, para a saúde pública, em face da alteração observada no perfil de saúde das sociedades ocidentais, onde algumas das morbimortalidades evitáveis poderiam ser minoradas pela adoção de estilos de vida saudáveis, fato enfatizado pelo projeto Cidades Saudáveis.

Por imperativos de sustentabilidade e de autonomia, os novos conceitos de mobilidade urbana exigem que o desenho da cidade e a sua gestão sejam reformatados à medida que são confrontados com as exigências do envelhecimento e das mudanças climáticas, numa lógica de sustentabilidade. É agora inquestionável a prioridade que deve ser dada à satisfação das múltiplas necessidades dos residentes urbanos sem comprometer a fruição, a pertença e a autonomia. As ruas, importantes eixos de circulação, onde a prioridade automóvel está a ser revista, devem acomodar estratégias potenciadoras de mobilidade suave e sustentável centrada nas pessoas. A cidade e os espaços públicos de circulação e lazer têm um importante papel social a cumprir, 
repensando o contexto de multifuncionalidade, acessibilidade e habitabilidade e contribuindo para ligar pessoas, melhorar as condiçóes de segurança, autonomia e pertença de todos os habitantes, mas, particularmente, dos mais vulneráveis. Para tornar o espaço público seguro e fruível, é importante que os diferentes modos de transporte a acomodar na cidade assegurem conectividade entre lugares, permitindo uma utilização diária e confortável. No caso dos idosos, a necessidade de conectividade parece estar ligada à satisfaçáo de necessidades quotidianas, contribuindo para o acumular de minutos de atividade física e socializaçáo: "A população idosa deseja realizar suas atividades com independência e participa ativamente de eventos sociais, culturais e familiares, necessitando de autonomia e segurança, para garantir mobilidade e qualidade de vida" (Micheletto, 2011).

A par dos novos hábitos associadas à mobilidade suave/alternativa em meio urbano, tal como demonstraram Gyllencreutz e Saveman (2015), é urgente e necessário que novas regras sejam definidas, especialmente quando abordamos a problemática de percursos urbanos partilhados por peões e por veículos elétricos com motor, sejam bicicletas ou trotinetas. Sáo diversas as cidades europeias que, num passado recente, passaram a disponibilizar esse tipo de transporte alternativo, ainda que com graves lacunas legislativas, nomeadamente quando se trata de harmonizar a sua presença com a segurança dos peóes e com os respectivos códigos rodoviários, nacionais ou locais. Essa questão ganhou crescente relevância após a divulgação daquilo que parece ter sido, à data, o primeiro acidente mortal em espaço europeu, ocorrido após a colisão de uma trotinete com um peão (cidadã com 90 anos), na cidade de Barcelona (Garcia, 2018). Um estudo produzido por Trivedi et al. (2019), tendo como universo dados recolhidos em unidades de emergência médica de dois hospitais do sul da Califórnia, (setembro de 2017 a agosto de 2018), revelou que, dos 249 acidentes validados, 8,4\% ( $\mathrm{n}=21)$ envolviam ferimentos em peóes.

Para além da crescente reformulação que as questôes de segurança devem merecer a propósito do uso partilhado do espaço público, demonstrou-se, de igual modo, a pertinência e a oportunidade de melhoria no que se refere às questóes de segurança da pessoa idosa na habitação, protagonizadas por políticas públicas locais orientadas para a proteção dos mais vulneráveis.

O envelhecimento da população e a urbanização são o culminar bem-sucedido de um processo de desenvolvimento humano, uma conquista civili- 
zacional, pelo que temos a responsabilidade ética e moral de continuar uma discussão prolífica e partilhada capaz de contribuir para a sua melhoria contínua.

\section{Referências}

ALMEIDA, A. Avaliação da capacidade funcional e fatores associados nos idosos em centro de dia e apoio domiciliário no concelho de Coimbra (dissertação). Universidade de Coimbra, 2017. et al. (eds.). Manual de Boas Práticas: prevenção de quedas em idosos. Coimbra: Cáritas Diocesana de Coimbra, 2017.

AMPARHA - Programa de Apoio Municipal para Adaptação e Requalificação de Habitações. Câmara Municipal de Pombal; 2016. https://www.cm-pombal.pt/2016/03/30/programa-de-apoio-municipal-para-adaptacao-e-requalificacao-de-habitacoes/.

BLECH, J. Os inventores de doenças. Porto: AMBAR, 2006.

BODSTEIN, A. et al.. "A vulnerabilidade do idoso em situaçóes de desastres: necessidades de uma política de resiliência eficaz". Ambiente \& Sociedade, v. XVII, n. 2, p. 157-74, abr.-jun. 2014.

CABRAL, M. V. et al.. Processos de envelhecimento em Portugal: usos do tempo, redes sociais e condiçôes de vida. Lisboa: Fundação Francisco Manuel dos Santos, 2013.

CARMO, I. Risco de queda em idosos na comunidade: contributo para a construção de um instrumento de avaliação (dissertação). Escola Superior de Enfermagem do Porto, 2014.

CUMMING, E. e Henry, W. E. Growing old: the process of disengagement. Nova York: Basic Books, 1961.

DGS - Direção-Geral da Saúde. Ministério da Saúde. Programa Nacional de Saúde Escolar; Divisão Saúde Escolar. 2006. Disponível em: https://www. dgs.pt/paginas-de-sistema/saude-de-a-a-z/saude-escolar/ficheiros-externos/ programa-nacional-de-saude-escolar-pdf.aspx.

- Estratégia Nacional para a Promoção da Atividade Física, da Saúde e do Bem-estar (ENPAF). 2016.

. Ministério da Saúde. Estratégia para o envelhecimento ativo e saudável: 2017-2025. Jul. 2017. Disponível em: https://www.sns.gov.pt/wp-content/ uploads/2017/07/ENEAS.pdf. 
EASTERLIN, R.A. et al. "The impact of modern economic growth on urban-rural differences in subjective well-being”. World Development, v. 39, 2.187-98, 2011.

EDWARDS, N. e DULAI, J. "Examining the relationships between walkability and physical activity among older persons: what about stairs?". BMC Public Health, v. 18, n. 1, p. 1.025. Disponível em: https://doi.org/10.1186/ s12889-018-5945-0.

GARCIA, J. "Muere un peatón arroldao por un patinete eléctrico por pimera vez en España”. El País, 29 nov. 2018. Disponível em: https://elpais.com/ ccaa/2018/11/28/catalunya/1543417335_555775.html.

GHIDINI, R. "A caminhabilidade: medida urbana sustentável”. Revista dos Transportes Públicos - ANTP, ano 33, 2011.

GRAGNOLATI, M. et al. Growing old in an older Brazil: implications of population aging on growth, poverty, public finance and service delivery. Washington: The World Bank Publications, 2011.

GYLLENCREUTZ, L. e SAVEMAN, B. "Everyday outdoor mobility in old age: focus group interviews with active senior citizens". Healthy Aging Research 4:32, 2015.

HAESBAERT, R. "Território, poesia e identidade". Espaço e cultura, n. 3, , 1997. Disponível em: https://www.epublicacoes.uerj.br/index.php/espacoecultura/article/viewFile/6708/4786.

HAVIGHURST, R. "Successful Aging”. The Gerontologist, v. 1, p. 8-13, 1 mar. 1961. Disponível em: https://doi.org/10.1093/geront/1.1.8.

HOOF, Joost van et al. "The challenges of urban ageing: making cities age-friendly in Europe". International Journal of Environmental Research and Public Health, v. 15, n. 11, nov. 2018.

HWANG, E. e ZIEBARTH, A. "Walkability features for seniors in two livable communities: a case study". Housing and Society, v. 42, n. 3, p. 207-21, 2015. Disponível em: http://dx.doi.org/10.1080/08882746.2015.1121681. INSTITUTE FOR HEALTH AND EVALUATION. GBD 2017. University of Washington. Disponível em: http:/www.healthdata.org/.

LAGERROS, Y. T., LAGIOU, P. "Assessment of physical activity and energy expenditure in epidemiological research of chronic diseases". European Journal of Epidemiology, v. 22, n. 6, p. 353-62, 2007. 
MAGALHÁES, A. et al. "Vicinity of schools, but not of residences, seems to regulate physical and sports activities of 13-year-old teenagers in a South European setting”. J Phys Act Health, p. 1-20, 24 out 2016.

MARQUES DA COSTA, E. "Cidades Saudáveis, saúde e sustentabilidade: dos conceitos às orientaçôes de política na UE”. In e LIMA, S. C. (orgs.). Construindo Cidades Saudáveis. Uberlândia: Assis, 2013, p. 41-59. MICHELETTO, T. "O risco do idoso pedestre nas vias urbanas". São Paulo: Companhia de Engenharia de Tráfego, 2011. Disponível em: http://www. cetsp.com.br/media/96549/nt219.pdf.

PROGRAMA NACIONAL DE PREVENÇÃO DE ACIDENTES. Projeto: com mais cuidado. Ministério da Saúde, 2012.

NOSSA, P. "Participação, governação e inclusão: os contributos da rede de Cidades Saudáveis no domínio da saúde e do trabalho". In SOARES, B. et al. (orgs.). Construindo Cidades Saudáveis: utopias e práticas. Uberlândia: Ed. Assis, 2017, p. 123-60.

OECD. Ageing in the cities. Paris: OECD Publishing, 2015. Disponível em: http://dx.doi.org/10.1787/9789264231160-en

. Ageing: debate the issues. Paris: OECD Publishing, Paris, 2015. (OECD Insights). Disponível em: http://dx.doi.org/10.1787/9789264242654-en.

OLIVEIRA, A. et al. "Assessing functional capacity and factors determining functional decline in the elderly: a cross-sectional study". Acta Med Port, v. 32, n. 10, p. 654-60, out. 2019. Disponível em: https://actamedicaportuguesa.com/revista/index.php/amp/article/view/11974.

OPAS/OMS. Envelhecimento ativo: uma política de saúde. Brasília; 2005.

PEREIRA, A. "Formar idosos para trazerem as vozes de idosos mais excluídos". Público, 16 out. 2015. Disponível em: http://www.publico.pt/sociedade/ noticia/formar-idosos-para-trazerem-as-vozes-de-idosos-mais-excluidos-1711314 ? page $=-1$.

. "E se os hospitais tivessem um serviço só para idosos?”. Público, 21 jun. 2018. Disponível em: https://www.publico.pt/2018/06/21/sociedade/ noticia/um-servico-hospitalar-so-para-os-mais-velhos- 1835293.

PEREIRA, S. Ambiente construido - atividade física: uma equação para a saúde - perspetiva interdisciplinar sobre a construção da cidade saudável (tese). Universidade de Lisboa, 2017.

REBELO-MARQUES, Alexandre et al. "Aging hallmarks: the benefits of physical exercise". Frontiers in Endocrinology, v. 9, p. 1-15, 2018. 
RESENDE-OLIVEIRA, C. et al.. "Growing old in Portugal”. In LI, Yushi (Boni) (ed.). Global aging issues and policies: understanding the importance of comprehending and studying the aging process. Springfield, Illinois: Charles Thomas - Publishers, Ltd., 2013, p. 196-209.

SÁ-MOURA, Bebiana et al. "Bridging health and social care with the citizens - the case of EIT Health Project 'Healiqs4cities' and 'Praça Vida+', in Portugal”. Care Weekly, v. 2, 2018, p. 21-24. SARTOR, B. A prevalência da violência contra idosos no contexto do envelhecimento populacional e dos cuidados continuados de saúde no Brasil com uma contribuição da experiência portuguesa (dissertação). Universidade de Coimbra, 2014.

SMEDLEY, T. "Are urban environments best for an ageing population? Disponível em: https://www.theguardian.com/sustainable-business/blog/ urban-environments-ageing-population-design.

SORENSEN, J. F. L. "Rural-urban differences in life satisfaction: evidence from the European Union”. Regional Studies, v. 48, p. 1.451-66, 2014.

STANFORD CENTER ON LONGEVITY. Livable community indicators for sustainable aging place. 2013. Disponível em: http://longevity3.stanford. edu/wp-content/uploads/2013/03/mmi-livable-communities-study.pdf.

TORNSTAM, L. "The quo vadis of gerontology: on the scientific paradigm of gerontology". The Gerontologist, v. 32, p. 318-26, 1992.

TRIVEDI et al. "Injuries associated with standing electric scooter use". JAMA Network Open, v. 2, n. 1, 2019.

UNITED NATIONS (A). Department of Economic and Social Affairs, Population Division. World Urbanization Prospects: the 2018 Revision (ST/ESA/ SER.A/420). Nova York: United Nations, 2019. Disponível em: https:// www.un.org/development/desa/publications/2018-revision-of-world-urbanization-prospects.html.

(B). Department of Economic and Social Affairs, Population Division. Population Facts, n. ${ }^{\circ}$ 2019/2, abr. 2019.

(C). Department of Economic and Social Affairs, Population Division. World Population Prospects 2019: Highlights, jun. 2019. Disponível em: https://population.un.org/wpp/.

(D). Department of Economic and Social Affairs, Population Division. World Urbanization Prospects 2018: Highlights (ST/ESA/SER.A/421). Nova York, 2019. Disponível em: https://population.un.org/wup/Publications/ Files/WUP2018-Highlights.pdf. 
VAN CAUWENBERG, . et al. "Relationship between the physical environment and physical activity in older adults: a systematic review". Health Place, v. 17, p. 458-69, 2011.

VAN HOLLE et al. "Relationship between neighborhood walkability and older adults' physical activity: results from the Belgian Environmental Physical Activity Study in Seniors (BEPAS Seniors)". International Journal of Behavioral Nutrition and Physical Activity, n. 11, 2014. Disponível em: http://www.ijbnpa.org/content/11/1/110.

WIRTH, L. "O urbanismo como modo de vida". In VELHO, O. (org.). O fenómeno urbano. 4. ed. Rio de Janeiro: Zahar, 1979.

WHO. Active ageing: a policy framework. Geneva, 2002.

. Global recommendations on physical activity for health. Geneva, 2010. Disponível em: https://www.who.int/dietphysicalactivity/publications/9789241599979/en/.

. World Population Prospects: the 2010 Revision. Disponível em: http:// www.esa.un.org/unpd/wpp.

. Draft 1: global strategy and action plan on ageing and health. Geneva, 2015.

. European Healthy Cities Network. Geneva, 2017. Disponível em: http:/www.euro.who.int/en/health-topics/environment-and-health/urban-health/who-european-healthy-cities-network. 


\title{
Capítulo 11 \\ Atuação da rede de gestão empresarial no território brasileiro no início do século XXI
}

\author{
Paulo Wagner Teixeira Marques \\ Miguel Ângelo Ribeiro
}

\section{Considerações iniciais}

Uma das principais preocupaçóes atuais da Geografia é a busca de entendimento sobre as formas de organização do território. Nesse sentido, é inegável que as formas de organizaçáo em rede ganharam destaque no período histórico atual, em grande parte impulsionadas pelo acentuado avanço nas tecnologias de comunicação e de transportes. Entretanto, o padrão clássico centro-periferia não perdeu por completo a sua utilidade e é, em muitos casos, a melhor forma de explicação para as influências exercidas sobre o território. A descrição desses padróes e o entendimento de sua lógica e de suas propriedades tornam-se fundamentais para a compreensão do próprio território.

Simplificadamente, o Estado e o Mercado são as duas instituiçôes com o maior poder estruturador do espaço, atuando por meio de suas organizaçóes: de um lado, os organismos públicos criados para atender a população, levantar dados e informaçóes e recolher tributos; de outro, as empresas, sejam elas privadas, estatais ou sob qualquer outro arranjo societário funcionando no mercado, com suas estratégias particulares.

Tais empresas configuram uma das manifestaçóes da rede urbana brasileira em seu arranjo espacial, no qual os nós dessa rede - as cidades - apresentam papel de gestão (controle do território), materializando articulaçóes entre si em diferentes setores da economia e escalas espaciais (Corrêa, 2018). 
Nesse contexto, o presente capítulo aborda o tema dos nós e das conexões entre as cidades brasileiras e a articulação entre os espaços baseado na atuação das empresas, tanto privadas quanto públicas, desde que possuam sedes e filiais localizadas em municípios distintos, e em sua rede de filiais espalhadas pelo país. Interessa-nos analisar de que maneira o mercado, ao atuar por meio de empresas multilocalizadas, estabelece e cristaliza centralidades e hierarquias, organizando o território segundo interesses específicos que, muitas vezes, diferem da lógica de atuação do Estado na realização de suas tarefas específicas.

A principal questáo que se buscará responder aqui é a de como se apresenta estruturada a rede de gestão empresarial no território brasileiro neste início de século XXI. Tal questão está fundamentalmente atrelada ao papel de gestáo dos centros (organização) que configuram essa rede e sua atuação (escalas espaciais).

Sendo assim, este capítulo é dividido em três partes. Na primeira encontram-se as bases históricas e conceituais que o ancoram, nas quais o conceito de rede tem papel de destaque, organizando e reorganizando o território nacional a partir dos nós e de suas articulaçóes em diferentes escalas espaciais. A segunda diz respeito à operacionalização, a qual se constitui na apresentação da metodologia empregada (fontes e procedimentos) e da base de dados utilizada, enquanto a terceira mostra os resultados da articulação entre teoria, operacionalização e empiria. Por fim, nas consideraçóes finais, novas indagações serão apontadas, bem como uma agenda para futuras pesquisas.

\section{Uma visão geográfica do conceito de redes}

Convém de imediato explicitar o que estamos entendendo por redes geográficas. Para tal, apoiamo-nos em Corrêa (2018, p. 50) quando, de forma breve, aponta que se trata do "conjunto de localizaçóes humanas articuladas entre si por meio de vias e fluxos", ou seja, de uma rede social que se torna geográfica quando esta é considerada em sua espacialidade, expressa em localizaçóes qualificadas e articulaçóes espaciais entre elas. Como aponta o autor, "as redes geográficas estáo em toda parte" (p. 52).

Após essa breve conceituação das redes geográficas, convém explicitar o nosso entendimento sobre o que seriam as redes de gestáo. Segundo Ribeiro (2001), a partir de Miossec (1976), os lugares, ao mesmo tempo que apresentam uma hierarquia nacional e internacional que interage com a organização 
do trabalho e com as formas organizacionais de produção das grandes firmas, especializam-se num processo de divisão territorial do trabalho que vem se acentuando, e estáo cada vez mais submetidos a um controle centralizado em alguns raros pontos do território. Esse controle advém das decisões tomadas por dois entes que interagem no espaço: o Estado e a empresa privada.

A figura 1 apresenta a distinção entre as três possibilidades de um centro (nó) exercer seu papel em uma das três redes identificadas por Miossec (1976) e esquematizadas por Ribeiro (2001). Conforme aponta Corrêa (2018, p. 60), "a inserção de um centro urbano em diversas redes geográficas traz à tona o problema de suas posiçóes relativas em cada rede". Essa afirmativa ratifica o papel dos centros urbanos nos três tipos de rede.

Nesse sentido, a ascensão de novas formas de organização empresarial e as políticas de localização das redes de filiais das empresas, com a consequente influência exercida até mesmo sobre a atuação do Estado, tornam o tema da rede de gestão essencial para o entendimento do comportamento da sociedade e das formas e fluxos que se estabelecem no território brasileiro (Santos, 2002). Entretanto, apesar de sua centralidade para a compreensão das relações de poder, o tema permaneceu à margem de estudos aprofundados no Brasil nos últimos anos, a despeito de sua importância e dos trabalhos e avanços ocorridos no exterior e do próprio histórico de pesquisas sobre o tema realizados no país nas décadas de 1960, 1970 e 1980. As poucas exceçóes, que não podemos deixar de mencionar, incluem as pesquisas de Roberto Lobato Corrêa (1982, 1997a, 1997b, 1997c, 1997d, 2006), do IBGE (1987) e de Milton Santos (1979, 1999, 2002, 2008a, 2008b).

No contexto atual, fortemente influenciado pela evolução das formas gerenciais e de produção, consequência lógica da mobilidade e da facilidade de comunicação proporcionada pela revolução da eletrônica e da informática, os agentes econômicos - as empresas - passaram a se aproveitar dos recursos dispersos pelas diversas localidades, contornando as barreiras espaciais. Testemunha-se esse processo observando-se o padrão locacional formado pelas unidades locais das empresas, ou seja, a rede de filiais dispersas pelo país que se relacionam com as suas sedes nacionais, configurando os centros de gestáo e comando da rede nacional. Ainda que existam variaçóes nesse padrão em rede devido às diversas estratégias particulares de atuação no mercado, os padróes agregados de atuação são, ao mesmo tempo, uma configuração influenciada 
pelos padrôes espaciais pretéritos e uma força modeladora sobre a organização do espaço, em um movimento contínuo de reforço mútuo.

Figura 1 - Tipos de redes

\section{Tipos de Redes}

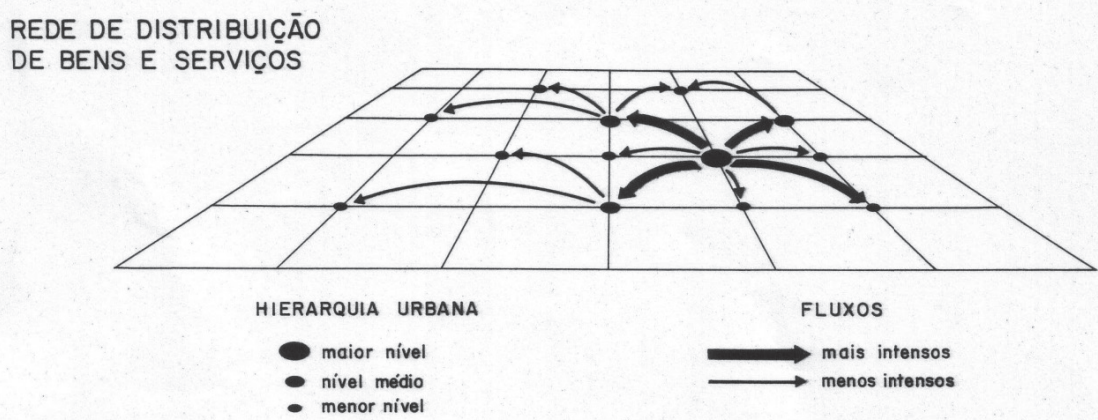

REDE DE PRODUC̄ĀO

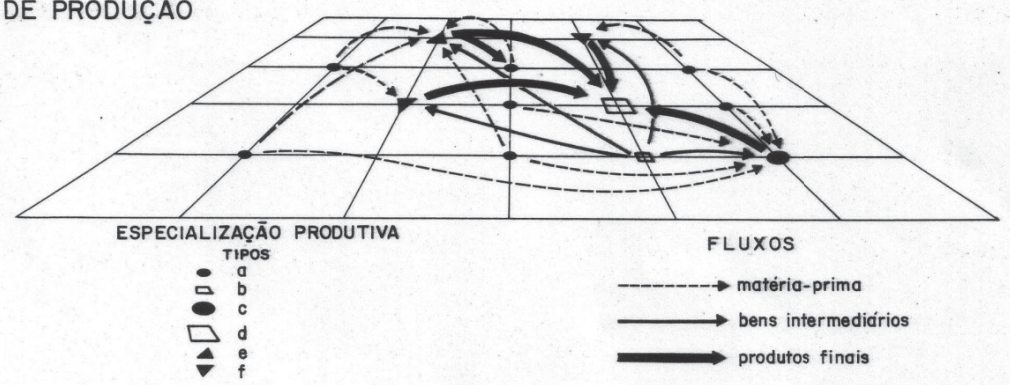

REDE DE GESTĀO

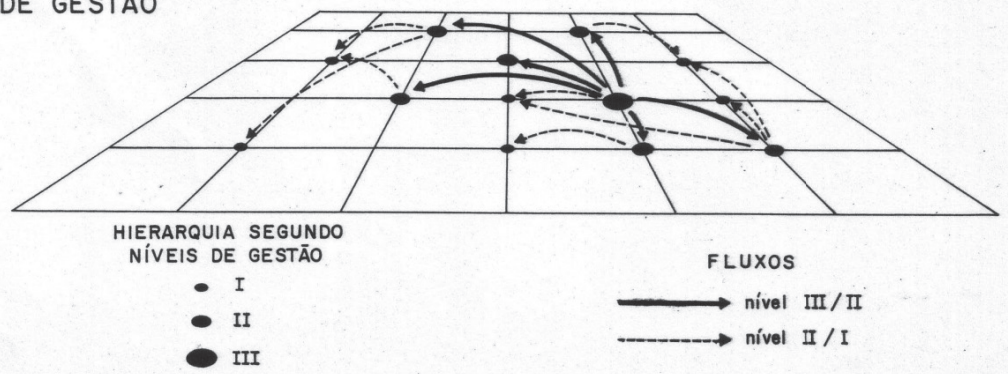

Fonte: Organizado por Ribeiro, 1995

Desenho: Paulo A. M. Silva 
De acordo com Hall (1996), a geografia regional e a geografia urbana resultante das organizaçóes em rede caracterizam-se por nítidas divisóes espaciais de trabalho, com a descentralização das funções de produção. Entretanto, cada vez mais as funçóes de comando e gestão encontram-se concentradas em poucos lugares: poucas cidades comandam as cadeias produtivas cruciais e de maior rentabilidade, e o poder de decisão de alto nível acha-se cada vez mais centralizado; outras atividades acabam descentralizadas ou situadas localmente, dentro das áreas metropolitanas principais, ou espalham-se de forma mais aberta pelo território nacional, pelas cidades médias e outras categorias de cidades (Corrêa, 1989b, 2007) ou por outros países (Castells, 1989).

Dessa forma, a tendência da reorganização espacial das empresas, que já vem ocorrendo desde o final do século XX, é a dispersão de unidades pelo território nacional e fora dele, em uma incessante busca por melhores condições de rentabilidade. Essa dispersão indica uma fuga da produção dos antigos centros industriais, que já não oferecem um retorno satisfatório. Paralelamente, ocorre uma descentralização local do trabalho de escritório, embora a atividade financeira e as transaçôes de serviços, especialmente os avançados, tornem-se cada vez mais concentradas em poucas cidades (Sassen, 1991). No caso brasileiro, essa concentração acontece principalmente nas metrópoles nacionais e regionais.

Quanto mais central for a posição de uma cidade na hierarquia urbana, maior será a possibilidade de desenvolver uma infraestrutura técnica e social sofisticada, capaz de atender às necessidades de sua população e das populaçóes vizinhas. Obviamente, ocorrem justaposiçóes no território, ou seja, ao mesmo tempo que o Estado age em consonância com padrôes clássicos de conformação de hinterlândias, o mercado atua no estabelecimento de redes. Assim, a centralidade passa a ser definida não apenas pelo acúmulo de funçóes urbanas, mas também pela capacidade das cidades de atrair, desenvolver e consolidar novas infraestruturas, permitindo maiores interaçóes com outras cidades, configurando uma complexidade que se manifesta em múltiplos circuitos, na qual o ciclo de reprodução do capital tem papel expressivo e, em se tratando da rede de empresas, entre elas, as corporações, há uma divisão territorial do trabalho, na qual cada centro especializa-se em dado papel, no qual produção, circulação e consumo capitalista são realizados (Corrêa, 2018). Serão essas estruturas que possibilitarão um aumento da oferta de bens e serviços para a população dispersa no território, atraindo o mercado e o próprio Estado e viabilizando a 
implantação de serviços cada vez mais sofisticados, capazes de abrigar novas funçôes de alto nível. Consequentemente, essa centralidade "reforçada" tenderá, a longo prazo, a ampliar as desigualdades entre as cidades, reforçando o desenvolvimento desigual entre elas.

De uma forma geral, as empresas, sejam elas públicas ou privadas, podem se territorializar de duas maneiras distintas e não excludentes entre si: em ligaçôes curtas, que reforçam centralidades preexistentes; e em ligaçóes mais distantes, por meio das redes descritas por Miossec (1976). Essa dupla orientação, que se reflete de diversas formas no território brasileiro, gera implicaçóes específicas para as populaçóes envolvidas. Grosso modo, no primeiro caso, o das ligaçôes curtas, o acúmulo de empresas cria pressôes consideráveis na rede de transportes e nos sistemas de saúde, habitação e educação das aglomerações urbanas; no segundo caso, é possível que as pressóes sobre o território ocorram na rede de escoamento da produção, havendo concomitantemente a subordinação da população e da política local a decisóes que ocorrem a dezenas, centenas ou milhares de quilômetros de distância.

Obviamente, esses são exemplos não exaustivos das possíveis consequências da ação das empresas em distintas localidades, sendo necessário um exame aprofundado das demais variáveis presentes para se chegar a uma análise mais próxima da realidade de cada uma delas.

Após essas breves consideraçôes teórico-conceituais, passemos à operacionalização.

\section{A operacionalização: fontes e procedimentos}

A metodologia empregada neste trabalho foi proposta inicialmente por Corrêa (1968). Utilizando o Registro Industrial de 1962, o autor pesquisou 42 mil fichas, anotando a localização da sede e do município em que se encontrava a sua filial, sempre que elas estivessem dissociadas espacialmente. Além dessa informação, ele também anotava a quantidade de trabalhadores da filial, o que constituiria um dos principais indicativos do alcance do comando de cada metrópole sob o território nacional.

Com essa abordagem, Corrêa buscou identificar o número de "assalariados externos” comandados pelas metrópoles, a sua distribuição espacial e os tipos de indústrias em que trabalhavam. Dessa forma, ele descortinava as relações de dependência dos municípios brasileiros em relação a cada 
uma das metrópoles brasileiras da época e o alcance espacial do poder de comando destas.

O trabalho desse pesquisador apresentou algumas limitaçóes que se devem à qualidade e à quantidade dos dados disponíveis à época e à tecnologia de processamento existente no final dos anos 1960. Resumidamente, as principais restriçóes da pesquisa estão na sua abrangência, que se limitou às metrópoles brasileiras, e no tipo de empresa pesquisada - apenas indústrias. $\mathrm{O}$ autor reconheceu a dificuldade de avaliar a localização das empresas filiais, pois o Registro Industrial indicava apenas uma ligação estática entre os estabelecimentos locais e a sede da empresa, conforme apontou:

vale assinalar também que o Registro Industrial indica apenas uma ligação estática entre estabelecimento e empresa, não havendo considerações sôbre a absorção de uma emprêsa por outra, nem a transferência da sede da emprêsa do lugar de produção, onde permaneceu o estabelecimento, para uma metrópole, como se verificou em diversos casos através de informações obtidas diretamente em algumas empresas ou em outras fontes (Corrêa, 1968, p. 58).

A metodologia utilizada por ele foi replicada, com poucas mudanças, em dois importantes trabalhos do IBGE, já no século XXI: Região de Influência das Cidades - REGIC 2007 (2008) e Gestão do Território (2014). Ambos se beneficiaram de uma extensa base de dados e da capilaridade do Instituto na coleta de informação sobre os municípios brasileiros.

Para este artigo, a base de dados que permitirá avançar no tema proposto é o Cadastro Central de Empresas - CEMPRE, divulgado anualmente pelo Instituto Brasileiro de Geografia e Estatística - IBGE. O CEMPRE é um acervo de dados sobre as empresas e demais organizações formais do Brasil. Nele encontram-se informações cadastrais e econômicas derivadas de pesquisas anuais do IBGE (Indústria, Construção Civil e Comércio e Serviços) e da Relação Anual de Informações Sociais - RAIS, do Ministério do Trabalho e Emprego. Essas informações apresentam-se desagregadas de acordo com os níveis de detalhamento da Classificação Nacional de Atividades Econômicas - CNAE 2.0 (ver quadro $1 \mathrm{e}$ anexo 1) e podem ser pesquisadas por Grandes Regiões, Unidades da Federação e Municípios. Estão disponíveis informações sobre pessoal ocupado total, pessoal ocupado assalariado, salários e outras remunerações e salários médios mensais, em salários mínimos. Outras informações importantes incluídas no CEMPRE 
são os indicadores de diversificação de atividade econômica e espacial e de concentração de pessoal ocupado total, relativos a indústria, comércio e serviços.

A estrutura do CEMPRE permite compor um quadro detalhado das relaçóes de controle e subordinação de pontos do território nacional e estabelecer uma hierarquização entre esses pontos. Considera-se, conforme mencionado anteriormente, o município como a escala de análise, e, consequentemente, os pontos representados serão o somatório das empresas cujas sedes ou filiais estejam presentes em um dado município.

O cadastro CEMPRE 2013, ano base utilizado neste trabalho, apresenta 5,2 milhôes de empresas e outras organizaçóes formais ativas para o ano de referência de 2012, que ocuparam, em 31 de dezembro, 53,4 milhóes de pessoas, sendo 46,2 milhões $(86,6 \%$ ) como pessoal ocupado assalariado e 7,1 milhóes $(13,4 \%)$ na condição de sócio ou de proprietário.

Quadro 1 - Classificação Nacional de Atividades Econômicas Grandes Categorias

\begin{tabular}{cl}
\hline & \multicolumn{1}{c}{ Seções } \\
\hline A & Agricultura, pecuária, produção florestal, pesca e aquicultura \\
\hline B & Indústrias extrativas \\
\hline C & Indústrias de transformação \\
\hline D & Eletricidade e gás \\
\hline E & Água, esgoto, atividades de gestão de resíduos e descontaminação \\
\hline F & Construção \\
\hline G & Comércio, reparação de veículos automotores e motocicletas \\
\hline H & Transporte, armazenagem e correio \\
\hline I & Alojamento e alimentação \\
\hline J & Informação e comunicação \\
\hline K & Atividades financeiras, de seguros e serviços relacionados \\
\hline L & Atividades imobiliárias \\
\hline M & Atividades profissionais, científicas e técnicas \\
\hline $\mathrm{N}$ & Atividades administrativas e serviços complementares \\
\hline $\mathrm{O}$ & Administração pública, defesa e seguridade social \\
\hline P & Educação \\
\hline
\end{tabular}




\begin{tabular}{cl}
\hline $\mathrm{Q}$ & Saúde humana e serviços sociais \\
\hline $\mathrm{R}$ & Artes, cultura, esporte e recreação \\
\hline $\mathrm{S}$ & Outras atividades de serviços \\
\hline $\mathrm{T}$ & Serviços domésticos \\
\hline $\mathrm{U}$ & Organismos internacionais e outras instituições extraterritoriais \\
\hline
\end{tabular}

Fonte: IBGE.

Obs.: No nível mais agregado, as categorias individuais da CNAE 2.0 estão organizadas em 21 seções.

Por fim, do cadastro inicial, foram selecionadas apenas as informaçóes referentes às empresas multilocalizadas, ou seja, aquelas que possuíam filiais em municípios diferentes dos municípios de suas sedes.

Os resultados produzidos pela agregação por município dos dados contidos no cadastro CEMPRE 2013, bem como a análise dos resultados, serão apresentados na próxima parte deste capítulo.

\section{Análise da rede de gestão empresarial no território brasileiro}

A metodologia empregada permitiu elaborar dois mapas distintos da atuação das empresas sobre o território brasileiro: o primeiro apresenta a situação atual da cadeia de comando e controle das empresas multilocalizadas no Brasil; o segundo apresenta os espaços opacos, ou seja, aqueles onde as empresas multilocalizadas estão ausentes ou não têm uma presença considerável a ponto de exercer uma influência significativa sobre esses espaços.

Basicamente, o que foi representado é o equivalente ao que é denominado "Intensidade" no trabalho Gestão do Território (IBGE, 2014). A "Intensidade" seria o equivalente ao somatório das empresas sediadas em um dado município X, das filiais dessas empresas localizadas em outros municípios diferentes de $\mathrm{X}$, das filiais de empresas com sede em municípios diferentes de X localizadas em X e das respectivas sedes dessas empresas (ver anexo 2).

Assim, o mapa 1 apresenta a dimensão espacial da gestão empresarial no Brasil para o ano de 2013. Ele representa o somatório das sedes e filiais de empresas multilocalizadas presentes em cada município brasileiro. A tabela contendo os 50 municípios com maior "Intensidade" encontra-se no anexo 2, ao final do livro. 
Para a confecção do mapa 1, foi adotada uma divisão dos municípios brasileiros em sete classes. Os municípios que apresentavam intensidade igual ou inferior a 100 estarão representados no mapa 2. As classes principais, ou seja, aquelas que efetivamente comandam a gestão empresarial no Brasil e que possuem a mais extensa rede de empresas representadas em seus territórios, aparecem concentradas na Regiáo Sudeste e, em alguma medida, nas Regióes Sul, Nordeste, Centro-Oeste e Norte. Com exceção da Região Sudeste, nas demais regiôes, a concentração de empresas ocorre nas capitais ou próximo a elas.

Mapa 1 - Principais cidades da rede de gestão empresarial no Brasil - 2013

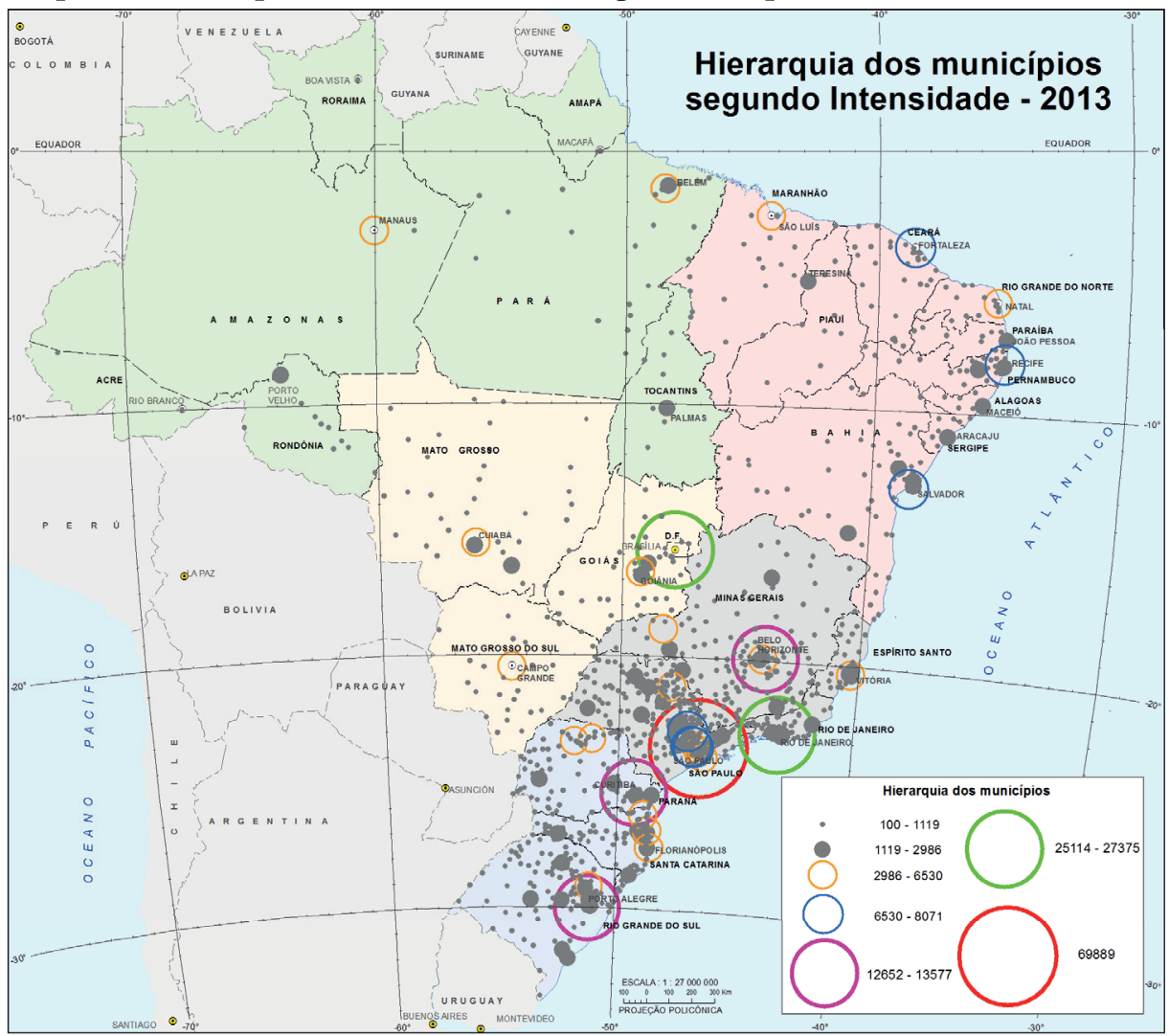

Fonte: Estatísticas do Cadastro Central de Empresas 2013. Rio de Janeiro: IBGE, 2016.

Em uma análise mais detalhada, tal mapeamento, grosso modo, distingue um padrão litorâneo na localização das cidades controladoras de empresas, principalmente municípios localizados próximo ao litoral das regi- 
óes Sul e Sudeste, do Rio Grande do Sul se estendendo até Minas Gerais e destacando-se São Paulo e Rio de Janeiro; um eixo litorâneo de menor intensidade da Bahia a Pernambuco; um interior esvaziado, com pequenos pontos, destacando-se a capital federal, mas concentrado a partir do sul de Minas Gerais em direção ao Rio Grande do Sul, ratificando o papel da regiáo concentrada identificada por Santos e Silveira (2001).

No tocante às 50 maiores cidades controladoras, podemos distinguir São Paulo como principal centro de gestão do país, superando em mais de duas vezes o Rio de Janeiro. Em segundo, destaca-se o Rio de Janeiro, em decorrência da presença, principalmente, da Petrobras, seguida de Brasília, com empresas controladoras federais. Em seguida, aparece Belo Horizonte. Podemos afirmar que, de modo geral, nesse conjunto das 50 maiores controladoras, 44,6\% dos assalariados externos são controlados pelas quatro metrópoles: São Paulo, Rio de Janeiro, Brasília e Belo Horizonte.

A tabela 1 corresponde ao agregado, por Unidade da Federação, das cidades desconectadas da rede de gestão empresarial no Brasil para o ano de 2013, simbolizadas no mapa 2 e que representam os municípios que possuem intensidade igual ou inferior a 100 e ficaram ausentes do mapa 1. Essas cidades desconectadas da rede de gestáo empresarial estáo concentradas no oeste catarinense, noroeste gaúcho, no oeste e noroeste paranaense, em especial próximo à divisa com o estado do Mato Grosso do Sul, sul e sudeste de Minas Gerais e no interior dos estados de Pernambuco, Paraíba, Alagoas e Sergipe.

A adoção da intensidade 100 como ponto de ruptura para que uma cidade fosse ou não incluída na relação das cidades conectadas ou não à rede de gestão empresarial é discricionária ${ }^{1}$. Porém, a escolha não é aleatória. Levando-se em consideração a natureza do indicador, que é composto pelas empresas multilocalizadas com sede em uma dada cidade X e suas filiais no Brasil, bem como pelas empresas com sede em outros municípios, mas que possuem

\footnotetext{
A tabela aqui apresentada destaca a quantidade de municípios por Unidade da Federação com "Intensidade" igual ou inferior a 100. Apenas para efeito comparativo, uma economia globalizada, como a do município de São Paulo, tem um valor de Intensidade igual a 69.899. Ou seja, um valor equivalente a 100, embora arbitrário, denota que a economia municipal é essencialmente local, sem muita participaçáo nas principais redes produtivas de seu estado ou do país, salvo raras exceçôes. No total, 4.459 de um total de 5.570 municípios no Brasil têm Intensidade igual ou inferior a 100, o que à primeira vista significa que, aproximadamente, $80 \%$ dos municípios brasileiros estão pouco integrados aos circuitos superiores da economia brasileira. Em outras palavras, são municípios cuja economia tem um alcance basicamente local.
} 
filiais naquela cidade, uma intensidade igual ou inferior a 100 significa que a cidade em questão possui pouca interação econômica, estando desconectada do circuito superior da economia brasileira (Santos, 2008).

Em números absolutos, 4.459 cidades apresentam valor de intensidade inferior ou igual a 100 (tabela 1). O somatório dos valores de intensidade dessas 4.459 cidades representa $15,4 \%$ do total da intensidade empresarial no Brasil, o que equivale ao valor de 127.402. Em contraposição, os demais 1.106 municípios representam $84,6 \%$ do total da intensidade empresarial no Brasil e somam o equivalente a 697.652 de intensidade. Esse valor é próximo ao de dez vezes a intensidade da cidade de São Paulo, principal nó da gestão empresarial no Brasil, calculada em 69.889.

O conjunto das cidades desconectadas da economia nacional compóe um quadro esclarecedor da concentração espacial da riqueza no Brasil. Analisando-o em conjunto com o mapa 1, tem-se um panorama da permanência das forças históricas que privilegiaram a ocupação e o desenvolvimento do litoral em detrimento do interior brasileiro.

Tabela 1 - Cidades desconectadas da rede de gestão empresarial no Brasil $-2013$

\begin{tabular}{llcc}
\hline Regiáo & UF & N. ${ }^{\text {de Municípios }}$ & $\begin{array}{c}\text { N. }{ }^{\circ} \text { de Municípios } \\
\text { com Intensidade } \\
\text { igual ou inferior a } \\
\mathbf{1 0 0}\end{array}$ \\
\hline Norte & 7 & 450 & 398 \\
\hline & Rondônia & 52 & 42 \\
\hline & Acre & 22 & 20 \\
\hline Amazonas & 62 & 60 \\
\hline Roraima & 15 & 14 \\
\hline Pará & 144 & 116 \\
\hline Amapá & 16 & 132 \\
\hline Tocantins & 139 & 1600 \\
\hline & 9 & 1794 & 198 \\
\hline & Maranhão & 217 & 213 \\
\hline
\end{tabular}




\begin{tabular}{|c|c|c|c|}
\hline & Ceará & 184 & 153 \\
\hline & Rio Grande do Norte & 167 & 152 \\
\hline & Paraíba & 223 & 212 \\
\hline & Pernambuco & 185 & 152 \\
\hline & Alagoas & 102 & 92 \\
\hline & Sergipe & 75 & 65 \\
\hline & Bahia & 417 & 363 \\
\hline \multirow[t]{5}{*}{ Sudeste } & 4 & 1668 & 1217 \\
\hline & Minas Gerais & 853 & 713 \\
\hline & Espírito Santo & 78 & 54 \\
\hline & Rio de Janeiro & 92 & 45 \\
\hline & São Paulo & 645 & 405 \\
\hline \multirow[t]{4}{*}{ Sul } & 3 & 1191 & 879 \\
\hline & Paraná & 399 & 307 \\
\hline & Santa Catarina & 295 & 201 \\
\hline & Rio Grande do Sul & 497 & 371 \\
\hline \multirow[t]{5}{*}{ Centro-Oeste } & 4 & 466 & 365 \\
\hline & Mato Grosso do Sul & 79 & 49 \\
\hline & Mato Grosso & 141 & 106 \\
\hline & Goiás & 246 & 210 \\
\hline & Distrito Federal & - & - \\
\hline Brasil & 27 & 5570 & 4459 \\
\hline
\end{tabular}

Fonte: ESTATÍSTICAS do Cadastro Central de Empresas 2013. Rio de Janeiro: IBGE, 2016. 
Mapa 2 - Cidades desconectadas da rede de gestão empresarial no Brasil 2013

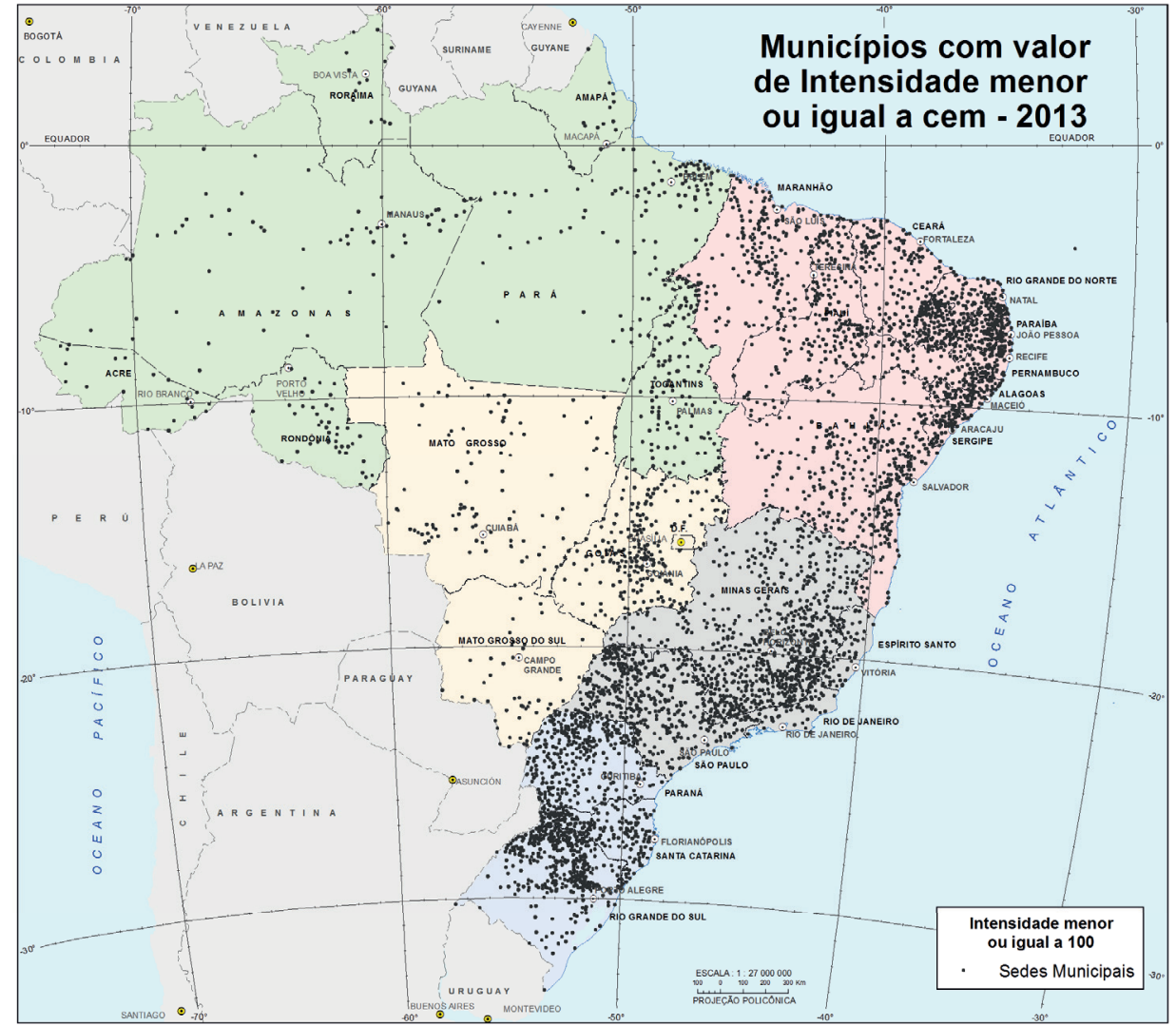

Fonte: Estatísticas do Cadastro Central de Empresas 2013. Rio de Janeiro: IBGE, 2016.

Ainda que tenha ocorrido um constante e intenso movimento de ocupação do interior brasileiro a partir das últimas décadas do século XX, em especial após a construção da nova capital, Brasília, ele ainda não foi suficientemente poderoso para configurar uma nova formação econômica no território brasileiro. Ou seja, a economia brasileira permanece fortemente ancorada próximo ao litoral, em especial no quadrilátero formado pelas cidades de São Paulo, Rio de Janeiro, Brasília e Belo Horizonte, que concentram boa parcela da riqueza e, principalmente, do poder de decisão nas esferas econômica e política no Brasil.

O mapa 3 apresenta os municípios que detêm o controle sobre os maiores contingentes de assalariados externos no Brasil. Entende-se assalariados externos como os empregados de empresas com sede em um município dife- 
rente daquele em que eles exercem o seu trabalho. Assim, se uma empresa é sediada no município de São Paulo, todos os empregados de suas filiais que não estejam no município de São Paulo são contabilizados como assalariados externos. Mais uma vez, observamos que os municípios de São Paulo, Rio de Janeiro, Brasília e Belo Horizonte respondem pelo maior quantitativo de assalariados externos. Em outras palavras, esses são os municípios que detêm o maior controle econômico sobre o território nacional, e as empresas sediadas em um desses quatro municípios são aquelas que empregam o maior contingente de trabalhadores fora dos limites territoriais de seus respectivos municípios-sede. A tabela contendo os 50 principais municípios com maior quantidade de assalariados externos encontra-se no anexo 3, ao final do livro.

Mapa 3 - Assalariados Externos: Municípios controladores no Brasil - 2013

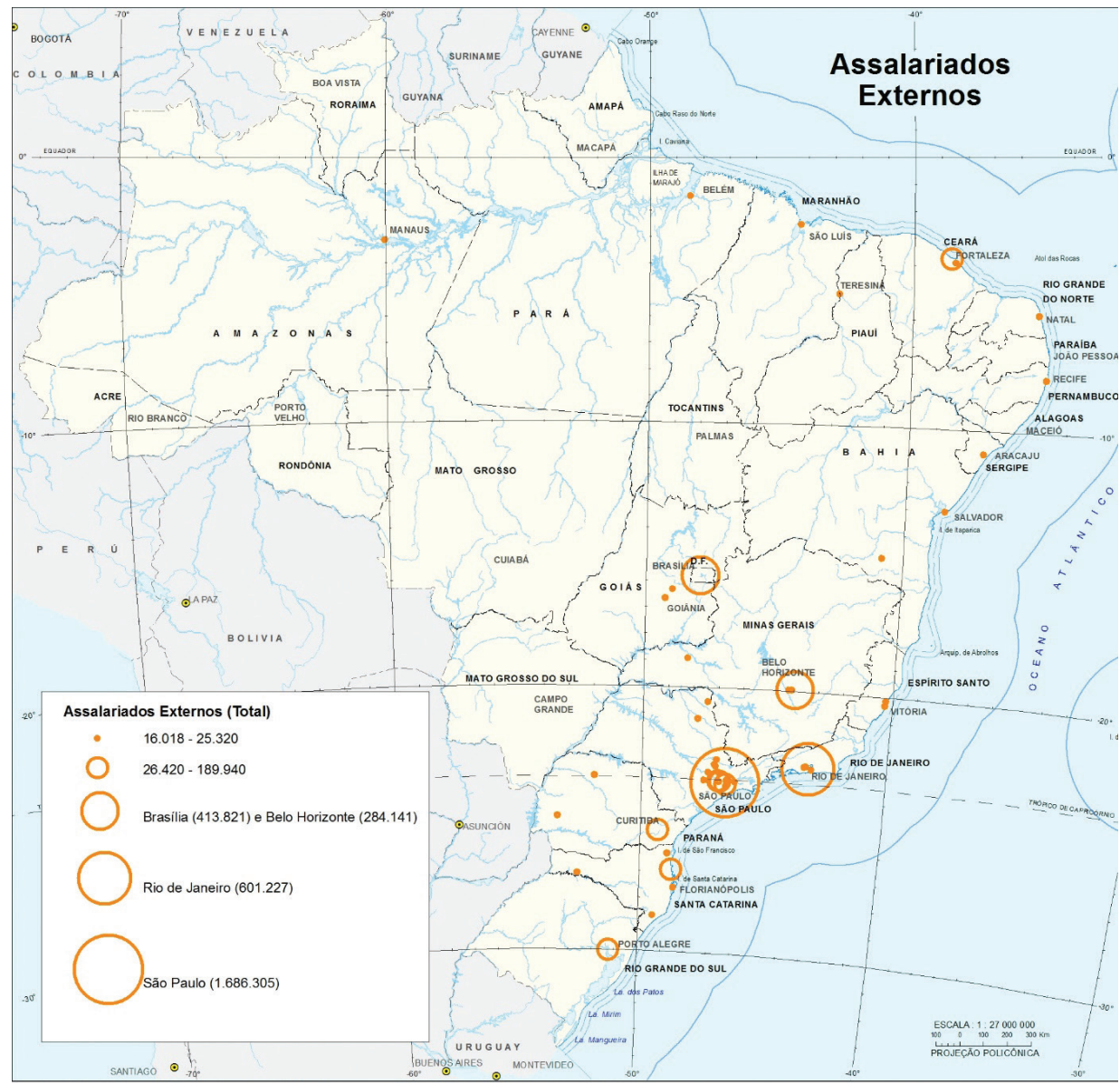

Fonte: Estatísticas do Cadastro Central de Empresas 2013. Rio de Janeiro: IBGE, 2016. 
Algumas considerações podem ser feitas quanto à análise dos referidos mapas, sendo nítida a importância assumida pelos eixos de transporte para a conexão do território à rede empresarial brasileira. No caso da Amazônia, o padrão rio é observado, com municípios e sedes municipais localizados na calha do rio Amazonas e seus afluentes, estando eles subordinados a Belém e Manaus, configurando uma rede regional, além dos vínculos com centros de gestão de outras porçóes do Brasil. Por outro lado, o padrão rodovia pode ser confirmado com os municípios litorâneos que estão sob a influência de metrópoles regionais e sob o comando de São Paulo, Rio de Janeiro e de outras metrópoles. Para clarificar tal assertiva, citemos o exemplo do estado de Pernambuco, no qual os municípios de menor intensidade de comando estão ligados à metrópole regional de Recife, mas podem estar também sob a influência de outras metrópoles externas, como São Paulo, metrópole nacional.

Sendo assim, quanto mais importante a hierarquia da cidade, seja quando atua como nó em uma das incontáveis redes possíveis ou como centro urbano fornecedor de bens e serviços em uma dada regiáo, maior a sua influência no conjunto das cidades brasileiras. Como não poderia deixar de ser, os padróes atuais representam uma herança espacial do desenvolvimento histórico das forças econômicas que atuaram no país ao longo de mais de 500 anos. Entretanto, as dinâmicas econômica, demográfica e espacial no Brasil continuam a promover mudanças na territorialização de empresas e na ocupação do território do país. Afinal, o sistema capitalista, em sua busca por novas fontes de recursos naturais e mercados consumidores, longe de apenas "padronizar" o território, alimenta-se das diferenças para a sua reprodução. E é justamente nas diferenças que pontos opacos do território podem se iluminar, e hierarquias há muito tempo cristalizadas podem ser subvertidas.

\section{Arremates}

Em um país com as dimensões do Brasil, marcado por profundas desigualdades socioespaciais e onde o poder público tem tradição de atuar tanto na economia quanto na sociedade, a gestão do território pode ser vista como um mosaico formado pela justaposição das redes empresariais e da organização centrada no Estado (IBGE, 2014). Portanto, mesmo que se pretenda analisar a maneira como as empresas organizam o território e, dentro dessa organização, busque-se identificar os principais nós de comando da rede empresarial, a 
compreensão da configuração desse território "das empresas” guarda profunda relação com o território do "Estado" (Marques, 2019).

A rede de gerenciamento empresarial das empresas multilocalizadas cujas sedes se encontram em território brasileiro representa a forma de territorialização do capital em busca de sua própria reprodução. Como mencionado anteriormente, de uma maneira geral, as empresas, sejam elas privadas, estatais ou qualquer outra situação societária intermediária que possam vir a ter, buscam, em geral, a melhor condição possível de lucratividade. Mesmo nos casos específicos em que essa premissa possa ser contestada, como ocorre com algumas empresas estatais, quando a lógica da ocupação do território e da prestação de serviços, ainda que em condiçôes deficitárias, sobrepuja a necessidade de lucro, usualmente são situações transitórias que não persistem no longo prazo.

Obviamente, o padrão em rede não é o único modelo de gestão atuando em um dado território em um momento específico no tempo. De fato, uma grande parte da gestão empresarial ocorre dentro de Concentraçóes Urbanas (IBGE, 2015) e assume um padrão regional ou contíguo no espaço. Assim, a dupla maneira pela qual o espaço é abordado, em rede e em contiguidade, demonstra a alta maleabilidade e adaptabilidade de algumas cidades às atuais formas de comando do território. Certamente, existem pontos de atrito entre as cidades, que em muitos casos sugerem uma competitividade por recursos e capitais, e é clara a existência de pontos mais luminosos ou mais opacos dentro das fronteiras brasileiras. Porém, os vencedores desses verdadeiros embates terminam por aprofundar as possibilidades de atração de novos investimentos e por incrementar sua influência em áreas ampliadas do território. Dessa maneira, o Brasil apresenta-se como um mosaico de redes empresariais, onde a forma centro-periferia permanece relevante. Partes do território, de acordo com essa lógica, passam a se conectar diretamente ao mercado global, enquanto outras retêm uma dinâmica mais baseada na contiguidade. Conceitualmente, Santos (1996) já havia descrito como, por meio de verticalidades e horizontalidades, o espaço se conforma a essa dupla influência das forças produtivas. Dependendo da força desses pontos, captada pela sua hierarquia na rede urbana nacional (IBGE, 2008), a influência se propagará por maiores ou menores distâncias.

Se o desenvolvimento capitalista ocorre de maneira desigual e combinada, seu reflexo no território é especialmente acentuado em condiçóes de incompletude da rede urbana, fator essencial para se compreender a forma que 
essa mesma rede urbana adquire no Brasil, e potencializado pelas deficiências estruturais existentes em um país a meio termo entre a riqueza e a pobreza.

Fruto do processo histórico de ocupação, a forma adquirida pela distribuição das cidades brasileiras ao longo de um território continental obedece a fatores e a agentes que têm interesses, na maioria das vezes, díspares e conflitantes. Somem-se a isso os diferentes atributos de poder de cada um desses agentes e as configuraçóes adquiridas pelos arranjos existentes entre eles, coordenados ou não, que transparecem na rede urbana brasileira e que se materializam nas cidades na própria forma que o urbano adquire, considerando-se os pontos de maior riqueza ou pobreza da urbanização imposta e as segregaçóes sociais e espaciais daí advindas.

A rede urbana brasileira, consequentemente, adquire uma forma cujo epicentro encontra-se em São Paulo. Brasília e Rio de Janeiro completam a tríade de cidades com maior influência na economia brasileira e onde se concentra a maioria das empresas multilocalizadas de abrangência nacional do Brasil. Belo Horizonte, gradativamente, aproxima-se dessas três cidades, anunciando a emergência de um quadrilátero de comando empresarial no Brasil. A porção meridional do território brasileiro apresenta-se densificada, em especial no litoral e próximo às capitais dos estados do sul. As ligaçóes empresariais aí são, em sua maioria, de curta distância, em geral, dentro dos próprios arranjos populacionais. O Nordeste brasileiro, nessa configuração, surge com empresas locacionadas nas capitais e, pontualmente, no interior da região, mas com poucas ligaçóes multilocalizadas em âmbito nacional. Por último, as Regióes Centro-Oeste e Norte apresentam-se com poucas empresas de âmbito nacional, o que não significa ausência completa destas.

É importante, todavia, recordar que as flutuaçóes conjunturais da economia do país aparecem refletidas no território no curto prazo. Porém, a forma da rede de gestão das empresas brasileiras apresenta uma surpreendente permanência estrutural, de longo prazo, quando se comparam os resultados de Corrêa (1968) e o atual, mesmo levando-se em consideração a diferença nas abrangências territoriais das duas pesquisas. Tal fato não significa que novos empreendimentos não tenham sido desenvolvidos ao longo dos quase 50 anos entre um trabalho e outro, mas que os locais onde foram implantados esses novos empreendimentos, em geral, não mudaram ao longo do tempo. Isso corrobora a permanência do formato da rede de gestão das empresas multilocalizadas no Brasil e reafirma o seu caráter estrutural. 
Nesse contexto, no Brasil, cuja rede urbana encontra-se em processo de consolidação em largas porções do território, as regiôes e redes possuem um papel fundamental para o entendimento da forma e da organização constituídas. As variáveis atuantes na constituição das regióes e redes, entre elas, os vetores externos, possuem arranjos específicos, onde se misturam influências políticas e interesses diversos, como os de acesso a mercados de máo de obra, matérias-primas e consumidores. Assim, as formas finais assumidas em cada localidade são resultado desse jogo de forças e de interesses distintos, onde as horizontalidades e as verticalidades irão desempenhar papel fundamental na hierarquia urbana nacional (Santos, 2008a). Posto isso, conforme aponta Corrêa (2018, p. 54), "a rede urbana pode, assim, ser vista como a rede-síntese das demais redes geográficas, ela própria sendo uma rede geográfica”.

Resta, como sugestáo para trabalhos futuros que aprofundem a temática aqui abordada, a realização de novos trabalhos sobre a natureza das ligaçóes econômicas dos quatro principais centros de comando da rede urbana brasileira. Essas futuras pesquisas poderiam ser feitas tendo em vista a distância média do alcance das ligaçôes empresariais oriundas dessas cidades, ou seja, se elas são majoritariamente curtas, internas às suas respectivas concentrações urbanas, médias ou de longa distância. Uma outra possibilidade é analisar em que setor se concentram as empresas dos maiores centros econômicos do Brasil e a sua ligação com centros fora do país. Pensando-se nas cidades desconectadas da rede empresarial brasileira, é desejável a realização de trabalhos que verifiquem as razóes para que elas se encontrem nessa condição e de simulaçóes que possam apontar um caminho que as leve a romper o isolamento econômico atual. Enfim, as possibilidades de novas pesquisas sobre esse tema são inúmeras.

Por fim, espera-se que este trabalho seja uma contribuição à compreensão e à análise da dimensão espacial do território brasileiro. Embora inscrito em uma área da geografia que tem larga tradição no país, não são muitos os artigos e dissertaçóes que o abordam sob o viés da gestão empresarial e, sobretudo, na escala nacional nos dias atuais.

\section{Referências}

BAHIANA, L. C. C. "Agentes modeladores e uso do solo urbano". Anais da Associação dos Geógrafos Brasileiros, v. 19, São Paulo, 1978. 
BRADFORD, M. G. e KENT, W. A. Geografia Humana: teorias e suas aplicações. Lisboa: Gradiva, 1987.

CARLOS, A. F. A. O espaço urbano: novos escritos sobre a cidade. São Paulo: FFLCH, 2007.

CASTELLS, M. The informational city: information technology, economic restructuring, and the urban-regional process. Oxford, UK; Cambridge, MA: Blackwell, 1989.

. "A sociedade em rede". A era da informação: economia, sociedade e cultura. São Paulo: Paz e Terra, 1999, v. 1.

. CENSO DEMOGRÁFICO 2010. "Características da população e dos domicílios: resultados do universo". Rio de Janeiro: IBGE, 2011. Disponível em: http://www.ibge.gov.br/home/estatistica/populacao/censo2010/caracteristicas_da_populacao/resultados_do_universo.pdf. Acesso em: 29 mar. 2016. CHRISTALLER, W. Central places in southern Germany. Englewood Cliffs, N.J.: Prentice-Hall, 1966.

CORRÊA, R. L. "Contribuição ao estudo do papel dirigente das metrópoles brasileiras". Revista Brasileira de Geografia, IBGE, v. 30, n. 2, p. 56-86, 1968.

. "Repensando a teoria das localidades centrais". In SANTOS, Milton (org.). Novos rumos da Geografia Brasileira. São Paulo: HUCITEC, 1982.

. Região e organização espacial. São Paulo: Editora Ática, 1986.

. "Os centros de gestão e seu estudo". Revista Brasileira de Geografia, IBGE, v. 51, n. 4, p. 109-19, 1989a. . A rede urbana. São Paulo: Ática, 1989b.

. "A rede de localidades centrais nos países subdesenvolvidos". Trajetórias geográficas. Rio de Janeiro: Bertrand Brasil, 1997a.

. "Corporação e espaço: uma nota". Trajetórias geográficas. Rio de Janeiro: Bertrand Brasil, 1997b.

. "Dimensões de análise das redes geográficas". Trajetórias geográficas. Rio de Janeiro: Bertrand Brasil, 1997c.

. "Interações espaciais". In CASTRO, I. E. et al. Explorações geográficas.

Rio de Janeiro: Bertrand Brasil, 1997d.

. Estudos sobre a rede urbana. Rio de Janeiro: Bertrand Brasil, 2006.

. "Construindo o conceito de cidade média". In SPOSITO, M. E. B. Cidades

médias: espaços em transição. São Paulo: Expressão Popular, 2007, p. 23-34. . Caminhos paralelos e entrecruzados. São Paulo: Ed. Unesp, 2018.

DINIZ, C. C. "Desenvolvimento poligonal no Brasil: nem desconcentração, nem contínua polarização". Revista Nova Economia, v. 3, n. 1, 1993.

HALL, P. Cidades do amanhã: uma história intelectual do planejamento e do projeto urbano no século XX. 3. ed. São Paulo: Perspectiva, 2007. 
IBGE - Instituto Brasileiro de Geografia e Estatística. Regiões de influência da cidade. Rio de Janeiro: IBGE, 1987. . Estatísticas do Cadastro Central de Empresas 2013. Rio de Janeiro: IBGE, 2016. Disponível em:

http://www.ibge.gov.br/home/estatistica/economia/cadastroempresa/2013/. Acesso em: 30 mar. 2016.

. Gestão do território: 2014. Rio de Janeiro: IBGE, 2014.

JACOBS, J. The economy of cities. Nova York: Random House, 1969.

MARQUES, Paulo Wagner Teixeira. Redes e regiões: como o Mercado e o Estado organizam o território no Brasil nas primeiras décadas do século XXI (Exame de Qualificação de Doutorado). UERJ, 2019.

MIOSSEC, Jean-Marie. "La localisation des forces de décision dans le monde: esquisse de géographie politique théorique”. L'Espace Géographique, n. 3, p. $165-75,1976$.

RIBEIRO, M. A. “As redes geográficas sob a ótica analítica de Miossec”. GeoUerj, Revista do Departamento de Geografia - UERJ, n. 10, p. 35-46, 2001.

. "O projeto de pesquisa a partir da rede urbana da Amazônia". In MARAFON, Glaucio José Marafon et al. (orgs.). Pesquisa qualitativa em Geografia: reflexões teórico-conceituais e aplicadas. Rio de Janeiro: EdUERJ, 2013.

SANTOS, Milton. Uma revisão da teoria dos lugares centrais: economia espacial, críticas e alternativas. São Paulo: HUCITEC, 1979.

. "Guerra dos lugares". Folha de São Paulo, Caderno Mais!, 8 ago. 1999. . A natureza do espaço: técnica e tempo, razão e emoção. São Paulo: EdUSP, 2002.

. Metamorfoses do espaço habitado: fundamentos teóricos e metodológicos da Geografia. São Paulo: EdUSP, 2008a.

. O espaço dividido: os dois circuitos da economia urbana e suas implicações espaciais. São Paulo: EdUSP, 2008b

SANTOS, Milton e SILVEIRA, Maria Laura. O Brasil: território e sociedade no início do século XXI. Rio de Janeiro: Editora Record, 2001.

SASSEN, Saskia. The global city: New York, London, Tokyo. New Jersey: Princeton University Press, 1991. 



\section{Anexo 1}

\section{CNAE 2.0}

De acordo com o IBGE, a Classificação Nacional das Atividades Econômicas - CNAE "é a classificação de atividades econômicas adotada na produção e na disseminação de estatísticas econômicas e na organizaçáo de cadastros da administração pública do país" (2019).

No nível mais agregado, as categorias individuais da CNAE 2.0 estão organizadas em 21 Seçóes. A tabela aqui apresentada mostra esse nível de agregação e a sua respectiva denominação. Essas 21 Seçôes são subdivididas em 87 Divisóes, 285 Grupos e 673 Classes, que abrangem todas as atividades econômicas desenvolvidas no Brasil. Uma vista mais aprofundada desta classificação pode ser encontrada na página do IBGE (www.ibge.gov.br).

CNAE 2.0 - Grandes categorias

No nível mais agregado, as categorias individuais da CNAE 2.0 estão organizadas em 21 seções, a seguir discriminadas:

\begin{tabular}{|c|c|c|c|c|c|}
\hline & & Seções & Divisões & Grupos & Classes \\
\hline & & Total & 87 & 285 & 673 \\
\hline A & $-01 . .03$ & $\begin{array}{l}\text { Agricultura, pecuária, } \\
\text { - produção florestal, pesca e } \\
\text { aquicultura }\end{array}$ & 3 & 12 & 34 \\
\hline $\mathrm{B}$ & $-\quad 05 . .09$ & - Indústrias extrativas & 5 & 8 & 16 \\
\hline $\mathrm{C}$ & $-10 . .33$ & - Indústrias de transformação & 24 & 103 & 258 \\
\hline $\mathrm{D}$ & 35 & - Eletricidade e gás & 1 & 3 & 6 \\
\hline $\mathrm{E}$ & $-\quad 36 . .39$ & $\begin{array}{l}\text { Água, esgoto, atividades } \\
\text { - de gestão de resíduos e } \\
\text { descontaminação }\end{array}$ & 4 & 6 & 11 \\
\hline $\mathrm{F}$ & $-41 . .43$ & - Construção & 3 & 9 & 21 \\
\hline G & $-\quad 45 . .47$ & $\begin{array}{l}\text { Comércio; reparação de } \\
\text { - veículos automotores e } \\
\text { motocicletas }\end{array}$ & 3 & 22 & 95 \\
\hline $\mathrm{H}$ & $-\quad 49 . .53$ & $\begin{array}{l}\text { Transporte, armazenagem } \\
\text { e correio }\end{array}$ & 5 & 19 & 34 \\
\hline
\end{tabular}




\begin{tabular}{|c|c|c|c|c|c|}
\hline I & $-55 . .56$ & - Alojamento e alimentação & 2 & 4 & 5 \\
\hline $\mathrm{J}$ & $-\quad 58 . .63$ & - Informação e comunicação & 6 & 14 & 32 \\
\hline $\mathrm{K}$ & $-64 . .66$ & $\begin{array}{l}\text { Atividades financeiras, } \\
\text { - de seguros e serviços } \\
\text { relacionados }\end{array}$ & 3 & 16 & 38 \\
\hline $\mathrm{L}$ & 68 & - Atividades imobiliárias & 1 & 2 & 3 \\
\hline M & $-\quad 69 . .75$ & $\begin{array}{l}\text { Atividades profissionais, } \\
\text { científicas e técnicas }\end{array}$ & 7 & 14 & 19 \\
\hline $\mathrm{N}$ & - $77 . .82$ & $\begin{array}{l}\text { Atividades administrativas e } \\
\text { serviços complementares }\end{array}$ & 6 & 19 & 34 \\
\hline $\mathrm{O}$ & 84 & $\begin{array}{l}\text { Administração pública, } \\
\text { defesa e seguridade social }\end{array}$ & 1 & 3 & 9 \\
\hline $\mathrm{P}$ & 85 & - Educação & 1 & 6 & 14 \\
\hline Q & $-\quad 86 . .88$ & $\begin{array}{l}\text { Saúde humana e serviços } \\
\text { sociais }\end{array}$ & 3 & 11 & 13 \\
\hline $\mathrm{R}$ & - $90 . .93$ & $\begin{array}{l}\text { - Artes, cultura, esporte e } \\
\text { recreação }\end{array}$ & 4 & 5 & 13 \\
\hline$S$ & - $94 . .96$ & $\begin{array}{l}\text { - Outras atividades de } \\
\text { serviços }\end{array}$ & 3 & 7 & 16 \\
\hline $\mathrm{T}$ & 97 & - Serviços domésticos & 1 & 1 & 1 \\
\hline $\mathrm{U}$ & 99 & $\begin{array}{l}\text { Organismos internacionais } \\
\text { - e outras instituiçốes } \\
\text { extraterritoriais }\end{array}$ & 1 & 1 & 1 \\
\hline
\end{tabular}

Fonte: IBGE 


\section{Anexo 2}

\section{Intensidade:}

Uma informação importante apresentada é a que se refere à intensidade total das ligaçóes de um dado município, dada pela Fórmula de Cálculo da Intensidade:

Intensidade $_{\mathrm{A}}=\sum$ Empresas $_{\mathrm{A}}+\sum \mathrm{ULs}_{\mathrm{A}}+\sum$ Empresas $_{\mathrm{XA}}+\sum \mathrm{UL}_{\mathrm{XA}}$

Onde:

$\sum$ Empresas $_{\mathrm{A}}$ é o somatório das empresas multilocalizadas sediadas no município A;

$\sum$ ULs $_{\text {A }}$ é o somatório das filiais em outros municípios das empresas multilocalizadas sediadas no município A;

$\sum$ Empresas $_{\mathrm{XA}}$ é o somatório das empresas multilocalizadas que possuem filiais no município A;

$\sum \mathrm{UL}_{\mathrm{XA}}$ é o somatório das unidades locais situadas no município A de empresas sediadas em outros municípios diferentes de A.

Assim sendo, a "Intensidade" é um indicativo do grau de inserção da economia de um município nos circuitos econômicos mais amplos de um país. Ela informa o quanto uma economia municipal está conectada às redes empresariais de outros municípios, seja em uma escala regional ou nacional. A tabela abaixo apresenta os 50 municípios brasileiros com maior "Intensidade”, o que significa dizer que são os municípios com maior integração na economia nacional.

Tabela de Intensidade dos Municípios Brasileiros

\begin{tabular}{clc}
\hline UF & MUNICÍPIO & INTENSIDADE \\
\hline SP & SÃO PAULO & 69.889 \\
\hline RJ & RIO DE JANEIRO & 27.375 \\
\hline DF & BRASÍLIA & 25.114 \\
\hline MG & BELO HORIZONTE & 13.577 \\
\hline PR & CURITIBA & 13.073 \\
\hline
\end{tabular}




\begin{tabular}{|c|c|c|}
\hline RS & PORTO ALEGRE & 12.652 \\
\hline $\mathrm{PE}$ & RECIFE & 8.071 \\
\hline $\mathrm{CE}$ & FORTALEZA & 8.062 \\
\hline SP & OSASCO & 8.046 \\
\hline $\mathrm{BA}$ & SALVADOR & 7.580 \\
\hline SP & BARUERI & 7.433 \\
\hline SP & CAMPINAS & 7.376 \\
\hline $\mathrm{GO}$ & GOIÂNIA & 6.530 \\
\hline SP & GUARULHOS & 5.796 \\
\hline SC & FLORIANÓPOLIS & 4.161 \\
\hline $\mathrm{AM}$ & MANAUS & 4.105 \\
\hline ES & VITÓRIA & 4.100 \\
\hline SP & RIBEIRÃO PRETO & 4.037 \\
\hline PA & BELÉM & 3.853 \\
\hline MG & UBERLÂNDIA & 3.766 \\
\hline MT & CUIABÁ & 3.736 \\
\hline SP & SÃO BERNARDO DO CAMPO & 3.701 \\
\hline SC & ITAJAÍ & 3.697 \\
\hline PR & LONDRINA & 3.689 \\
\hline MS & CAMPO GRANDE & 3.679 \\
\hline MG & CONTAGEM & 3.664 \\
\hline SC & JOINVILLE & 3.650 \\
\hline PR & MARINGÁ & 3.617 \\
\hline SP & SANTOS & 3.530 \\
\hline $\mathrm{RN}$ & NATAL & 3.145 \\
\hline RS & CAXIAS DO SUL & 3.129 \\
\hline SP & SANTO ANDRÉ & 3.084 \\
\hline MA & SÃO LUÍS & 3.027 \\
\hline SC & BLUMENAU & 2.986 \\
\hline SP & JUNDIAÍ & 2.780 \\
\hline ES & SERRA & 2.762 \\
\hline
\end{tabular}




\begin{tabular}{lll}
\hline SP & SÃO JOSÉ DOS CAMPOS & 2.761 \\
\hline RJ & NITERÓI & 2.748 \\
\hline RS & CANOAS & 2.650 \\
\hline SP & SOROCABA & 2.624 \\
\hline SP & SÃO JOSÉ DO RIO PRETO & 2.610 \\
\hline RJ & DUQUE DE CAXIAS & 2.580 \\
\hline SP & SÃO CAETANO DO SUL & 2.510 \\
\hline AL & MACEIÓ & 2.451 \\
\hline PB & JOÃO PESSOA & 2.395 \\
\hline PI & TERESINA & 2.362 \\
\hline PR & SÃO JOSÉ DOS PINHAIS & 2.204 \\
\hline SE & ARACAJU & 2.204 \\
\hline PE & JABOATÃO DOS GUARARAPES & 2.190 \\
\hline SC & SÃO JOSÉ & 2.181 \\
\hline & Fo: CaStO CEMPRE 2013 - IBGE
\end{tabular}

Fonte: Cadastro CEMPRE 2013 - IBGE 



\section{Anexo 3}

\section{Assalariados Externos}

A metodologia empregada neste trabalho segue os passos de Corrêa (1968) em seu trabalho pioneiro sobre a gestão empresarial das metrópoles brasileiras. Além de consagrada, uma vez que repetida em trabalhos do IBGE Instituto Brasileiro de Geografia e Estatística, ao longo das décadas seguintes, essa metodologia de pesquisa se beneficiou dos avanços ocorridos na coleta de dados e na sua manipulação ao longo das últimas décadas. Partindo de uma base de dados limitada no espaço, uma vez que concentrada nas principais metrópoles brasileiras, e nas categorias coletadas, circunscritas às indústrias, na década de 1960, os avanços havidos na informática possibilitaram a expansão do universo pesquisado, que hoje abarca a totalidade das cidades brasileiras e das atividades econômicas existentes no país.

A metodologia utilizada por Corrêa foi replicada, com poucas mudanças, em dois importantes trabalhos do IBGE, já no século XXI: Região de Influência das Cidades - REGIC 2007 (2008) e Gestão do Território (2014). Ambas se beneficiaram de uma extensa base de dados e da capilaridade do Instituto na coleta de informações sobre os municípios brasileiros.

A base de dados utilizada é disponibilizada pelo Cadastro Central de Empresas - Cempre 2013. Trata-se de um extenso repositório de informaçóes sobre as empresas brasileiras publicadas anualmente pelo IBGE. Por meio dela, é possível avaliar a qualidade da atividade econômica no país e observar flutuaçôes no comportamento das empresas que operam no Brasil.

Entre as informaçóes apresentadas pelo Cempre 2013, algumas foram cruciais para as conclusóes contidas neste capítulo, como, por exemplo, a quantidade de assalariados externos das empresas multilocalizadas do país. Entende-se empresas multilocalizadas como aquelas que possuem Unidades Locais (UL's) em municípios diferentes daquele da sua sede. Assim sendo, uma empresa cuja sede se encontre em São Paulo e possua filiais no Rio de Janeiro e em Belo Horizonte terá 2 "UL's Controladas" e a sua quantidade de assalariados externos será igual à soma dos 
empregados nessas filiais. Neste capítulo estão contemplados em ordem decrescente os quantitativos agregados das 50 cidades brasileiras com maior número de trabalhadores externos, que juntas controlam $73,5 \%$ dos assalariados externos do país.

Para uma mais fácil compreensão, o cálculo empregado para a coluna "Assalariados Externos" utilizou a seguinte fórmula:

Assalariados Externos ${ }_{\mathrm{A}}=\sum$ Funcionários ULs $_{\mathrm{A}}$

Onde:

$\sum$ Funcionários ULs A é o somatório dos funcionários das unidades locais das empresas multilocalizadas com sede no município A, excetuando-se os das unidades locais situadas em A (sede).

Tabela de Assalariados Externos - 50 principais municípios controladores no Brasil - 2013

\begin{tabular}{clcccc}
\hline UF & Nome Município & $\begin{array}{c}\text { Empresas } \\
\text { Controladas }\end{array}$ & $\begin{array}{c}\text { Municípios } \\
\text { Controlados }\end{array}$ & $\begin{array}{c}\text { ULs } \\
\text { Controladas }\end{array}$ & $\begin{array}{c}\text { Assalariados } \\
\text { Externos }\end{array}$ \\
\hline SP & SÃO PAULO & 8.386 & 2.406 & 42.676 & 1.686 .305 \\
\hline RJ & RIO DE JANEIRO & 2.770 & 1.014 & 11.405 & 601.227 \\
\hline DF & BRASÍLIA & 671 & 5.369 & 19.423 & 413.821 \\
\hline MG & BELO HORIZONTE & 1.604 & 1.050 & 5.720 & 284.141 \\
\hline SP & BARUERI & 621 & 453 & 4.699 & 189.940 \\
\hline RS & PORTO ALEGRE & 1.465 & 712 & 5.160 & 131.276 \\
\hline SP & OSASCO & 358 & 2.330 & 5.950 & 122.281 \\
\hline PR & CURITIBA & 1.695 & 812 & 5.203 & 105.992 \\
\hline SC & ITAJAÍ & 315 & 269 & 915 & 105.193 \\
\hline SP & SÃO CAETANO DO & 209 & 337 & 1.451 & 99.583 \\
\hline SUL & FORTALEZA & 988 & 564 & 3.315 & 91.464 \\
\hline PE & RECIFE & 927 & 343 & 2.493 & 64.861 \\
\hline SP & SÃO BERNARDO & 476 & 213 & 1.154 & 55.545 \\
\hline SP & CAMPINAS & 682 & 517 & 2.030 & 52.306 \\
\hline PR & MARINGÁ & 415 & 333 & 1.311 & 50.908 \\
\hline BA & SALVADOR & 791 & 469 & 2.007 & 50.605 \\
\hline AM & MANAUS & 417 & 287 & 1.343 & 41.061 \\
\hline & & & & & \\
\hline
\end{tabular}




\begin{tabular}{|c|c|c|c|c|c|}
\hline SP & SANTO ANDRÉ & 431 & 165 & 847 & 40.399 \\
\hline SP & GUARULHOS & 635 & 337 & 1.662 & 40.213 \\
\hline MG & CONTAGEM & 408 & 278 & 1.064 & 37.894 \\
\hline $\mathrm{GO}$ & GOIÂNIA & 864 & 358 & 2.023 & 35.973 \\
\hline SP & MOJI DAS CRUZES & 150 & 88 & 331 & 35.676 \\
\hline SE & $\begin{array}{l}\text { NOSSA SENHORA } \\
\text { DO SOCORRO }\end{array}$ & 35 & 156 & 448 & 32.891 \\
\hline SP & JUNDIAÍ & 259 & 294 & 1.013 & 31.022 \\
\hline $\mathrm{PA}$ & BELÉM & 391 & 282 & 1.503 & 28.616 \\
\hline SP & FRANCA & 115 & 524 & 1.025 & 26.592 \\
\hline $\mathrm{RJ}$ & DUQUE DE CAXIAS & 264 & 150 & 654 & 26.420 \\
\hline SC & JOINVILLE & 394 & 266 & 1.281 & 25.320 \\
\hline $\mathrm{RJ}$ & $\begin{array}{l}\text { SÃO JOÃO DE } \\
\text { MERITI }\end{array}$ & 118 & 42 & 543 & 25.210 \\
\hline ES & VITÓRIA & 503 & 240 & 1.357 & 22.970 \\
\hline PR & CASCAVEL & 271 & 224 & 769 & 22.683 \\
\hline SC & CHAPECÓ & 204 & 190 & 545 & 22.590 \\
\hline MA & SÃO LUÍS & 285 & 170 & 698 & 21.905 \\
\hline SP & JAGUARIÚNA & 44 & 83 & 142 & 21.447 \\
\hline $\mathrm{SC}$ & FLORIANÓPOLIS & 533 & 318 & 1.283 & 20.832 \\
\hline SP & SALTO & 61 & 223 & 335 & 20.709 \\
\hline $\mathrm{SP}$ & VALINHOS & 91 & 104 & 251 & 18.750 \\
\hline PI & TERESINA & 239 & 300 & 850 & 18.222 \\
\hline RJ & NITERÓI & 277 & 126 & 837 & 17.963 \\
\hline MG & BETIM & 141 & 170 & 435 & 17.785 \\
\hline $\mathrm{SP}$ & RIBEIRÃO PRETO & 406 & 245 & 943 & 17.539 \\
\hline $\mathrm{SC}$ & CRICIÚMA & 238 & 127 & 529 & 16.801 \\
\hline $\mathrm{GO}$ & ANÁPOLIS & 146 & 182 & 397 & 16.562 \\
\hline $\mathrm{CE}$ & EUSÉBIO & 71 & 73 & 220 & 16.512 \\
\hline $\mathrm{RN}$ & NATAL & 403 & 148 & 782 & 16.461 \\
\hline $\mathrm{SP}$ & SOROCABA & 310 & 202 & 662 & 16.423 \\
\hline MG & UBERLÂNDIA & 362 & 365 & 1.435 & 16.377 \\
\hline
\end{tabular}




\begin{tabular}{clcccc}
\hline SP & CARAPICUÍBA & 75 & 44 & 99 & 16.152 \\
\hline ES & SERRA & 328 & 189 & 691 & 16.151 \\
\hline \multirow{2}{*}{ BA } & $\begin{array}{l}\text { VITÓRIA DA } \\
\text { CONQUISTA }\end{array}$ & 111 & 213 & 688 & 16.018 \\
\hline & BRASIL & $\mathbf{9 0 . 1 9 0}$ & - & $\mathbf{2 6 3 . 4 9 3}$ & $\mathbf{6 . 7 0 0 . 3 6 1}$ \\
\hline
\end{tabular}

Fonte: estatísticas do Cadastro Central de Empresas 2013. Rio de Janeiro: IBGE, 2016. 


\section{Sobre os organizadores}

\section{Eduarda Marques da Costa}

Professora associada do Instituto de Geografia e Ordenamento do Território da Ulisboa; investigadora do Centro de Estudos Geográficos - Universidade de Lisboa; mestre e doutora em Geografia - Área de Especialização em Planejamento Regional e Local pela Universidade de Lisboa; coordena o grupo de investigação "MOPT - Modelação, Ordenamento e Planeamento Terrritorial”; suas áreas de interesse são o planeamento urbano e regional e a definição e avaliação de políticas públicas. Nos últimos 25 anos, participou e coordenou vários projetos de investigação, bem como estudos/estratégias ligados a instituiçóes públicas e privadas, destacando-se aqui a sua ligação a estudos da DG REGIO (participação no estudo Sustainable Urban Development in Portugal: an Integrated Approach), membro do Comité Cientifico de Regions 2020 - Phase 2 e a participação no Programa ESPON (colaboração em 7 projetos de 2000-2013 e membro do sounding board 2007-2013), nomeadamente em estudos de avaliação ligados aos fundos estruturais (2014, Ex-Post Evaluation of Cohesion policy programmes 2007-2013, focusing on the European Regional Development Fund (CF) - WP0.

\section{Glaucio José Marafon}

Professor associado da Universidade do Estado do Rio de Janeiro; pesquisador CNPq/ FAPERJ CNE. 


\begin{tabular}{c}
\hline \hline Formato $16 \times 23$ \\
Tipologia: Garamond (texto) Garamond (títulos) \\
Papel: Offset $90 \mathrm{~g} / \mathrm{m} 2$ (miolo) \\
Supremo $250 \mathrm{~g} / \mathrm{m} 2$ (capa) \\
CTP, impressão e acabamento: ???? \\
\hline
\end{tabular}

